\begin{tabular}{|c|c|}
\hline $\begin{array}{c}\text { Universidade de Brasilia } \\
\text { Universidade Federal da } \\
\text { Paraiba }\end{array}$ & $\begin{array}{c}\text { Universidade Federal do Rio } \\
\text { Grande do Norte }\end{array}$ \\
\hline \multicolumn{2}{|c|}{ Programa Multiinstitucional e Inter-Regional de Pós-graduação em Ciências Contábeis } \\
\hline
\end{tabular}

MATEUS ALEXANDRE COSTA DOS SANTOS

\title{
EVASÃO TRIBUTÁRIA, PROBABILIDADE DE DETECÇÃO E ESCOLHAS CONTÁBEIS: UM ESTUDO À LUZ DA TEORIA DE AGÊNCIA
}

JOÃO PESSOA/PB

2016 


\section{MATEUS ALEXANDRE COSTA DOS SANTOS}

\section{EVASÃO TRIBUTÁRIA, PROBABILIDADE DE DETECÇÃO E ESCOLHAS CONTÁBEIS: UM ESTUDO À LUZ DA TEORIA DE AGÊNCIA}

Tese apresentada ao Programa Multi-Institucional e Inter-Regional de Pós-Graduação em Ciências Contábeis da Universidade de Brasília, Universidade Federal da Paraíba e Universidade Federal do Rio Grande do Norte, como requisito parcial à obtenção do título de Doutor em Ciências Contábeis.

\section{Orientador:}

Dr. Paulo Roberto Nóbrega Cavalcante.

JOÃO PESSOA/PB 
S237e Santos, Mateus Alexandre Costa dos.

Evasão tributária, probabilidade de detecção e escolhas contábeis: um estudo à luz da teoria de agência / Mateus Alexandre Costa dos Santos.- João Pessoa, 2016.

$188 \mathrm{f}$.

Orientador: Paulo Roberto Nóbrega Cavalcante Tese (Doutorado) - UFPB/CCSA

1. Contabilidade. 2. Evasão tributária. 3. Probabilidade de detecção tributária. 4. Escolhas contábeis. 5. Teoria de agência. 6. Governança tributária. 


\title{
EVASÃO TRIBUTÁRIA, PROBABILIDADE DE DETECÇÃO E ESCOLHAS CONTÁBEIS: UM ESTUDO À LUZ DA TEORIA DE AGÊNCIA
}

Tese submetida à apreciação da banca examinadora do Programa Multi-institucional e Interregional de Pós-graduação em Ciências Contábeis - UnB, UFPB, UFRN, como requisito parcial à obtenção do grau de Doutor em Ciências Contábeis.
Prof. Dr. Paulo Roberto Nóbrega Cavalcante
Universidade Federal da Paraíba - UFPB
Orientador

\author{
Prof. Dr. Edilson Paulo \\ Universidade Federal da Paraíba - UFPB \\ Membro interno - PMIPGCC - UnB/UFPB/UFRN
}

Prof. Dr. Wenner Gláucio Lopes Lucena

Universidade Federal da Paraíba - UFPB

Membro interno - PMIPGCC - UnB/UFPB/UFRN

Profa. Dra. Márcia Reis Machado

Universidade Federal da Paraíba - UFPB

Membro interno - PMIPGCC - UnB/UFPB/UFRN

Prof. Dr. Mauro Fernando Gallo

Membro externo não vinculado - FECAP 
A Tiago Alexandre e à pequenina Maria Eduarda, filhos amados.

Por vocês, busco o meu melhor. 


\section{AGRADECIMENTOS}

A Deus pela conspiração favorável de acontecimentos, estados e sentimentos, que permitiram a conclusão deste trabalho.

Ao professor Paulo Roberto Nóbrega Cavalcante, meu orientador, pela precisão dos argumentos e por todo respeito e confiança, generosamente oferecidos.

Aos professores Edilson Paulo, Paulo Aguiar do Monte, Maria da Conceição Sampaio de Sousa e João Agnaldo do Nascimento, pela disposição de ouvir meus questionamentos e de contribuir com lições valiosas.

Aos professores Anderson Luiz Rezende Mol, César Augusto Tibúrcio da Silva, Ivan Ricardo Gartner, Jorge Katsumi Niyama e José Matias-Pereira, que tanto contribuíram com a minha evolução acadêmica.

Ao professor Mauro Fernando Gallo, por ter aceitado participar da avaliação desta tese e por suas valiosas contribuições.

Aos professores Wenner Gláucio Lopes Lucena e Márcia Reis Machado, pelas críticas e sugestões tão úteis no aprimoramento deste trabalho.

Aos funcionários do PMIPCC, Inês, Ivanacy, Rodolfo e Wilma, pelo atendimento eficiente, pontual e cordial.

Aos meus amigos Adriana, Daniel, Diego, Gilmara, Josicarla, Leonardo, Lidiane, Lúcio, Luiz e Márcia, pelo convívio fraterno e descontraído, que tornaram a caminhada mais agradável (sinto saudades), bem como pelas ricas discussões, profundas reflexões e apoio moral incondicional. Muitíssimo obrigado!

Ao professor Paulo Roberto Barbosa Lustosa, por todo incentivo, apoio e confiança, a mim oferecidos, desde o meu ingresso no mestrado.

Ao amigo Vinícius, cujo apoio foi fundamental para a finalização deste trabalho, pela generosidade em compartilhar conhecimento e instrumentos que facilitaram a execução da etapa empírica da pesquisa.

À minha esposa, Roseane Santos, pelo valioso apoio, pela cumplicidade e pelo suporte familiar. Aos meus amados filhos, Tiago Alexandre (Tiagão) e Maria Eduarda (Duda), cujo amor incondicional e sorrisos sinceros renovam a minha esperança em um mundo melhor e me fazem crer que isso começa no íntimo de cada um de nós. Amos vocês!

Aos meus pais, Antonio e Silvete, e minha querida sogra, "Dudinha", pelo carinho e pelo incentivo, bem como por todas as oportunidades que me foram oferecidas.

Por fim, agradeço a Aldo Callado, Luiz Felipe Girão, Ana Flávia Albuquerque, Andrea Chaves e todos os amigos que contribuíram de alguma forma para a realização deste trabalho. 
A mente que se abre a uma nova ideia jamais volta ao seu tamanho original.

Albert Einstein 


\section{RESUMO}

Em um ambiente de agência, a evasão tributária pode representar um mecanismo adicional para o exercício do oportunismo gerencial, de modo que a fiscalização tributária estatal atuaria como um instrumento externo de governança "à disposição" da firma. Essa é a ideia central do presente trabalho, cujo objetivo foi investigar o efeito da probabilidade de detecção tributária associada ao Imposto de Renda da Pessoa Jurídica (IRPJ) e à Contribuição Social sobre o Lucro Líquido (CSLL) sobre as escolhas contábeis das firmas brasileiras de capital aberto. Para tanto, foi desenvolvida uma estrutura teórico-analítica, com base na qual foram provadas as proposições teóricas que suportaram as hipóteses da pesquisa. Nessa análise, foram consideradas 4 decisões relacionadas à evasão tributária, as quais envolveram escolhas contábeis oportunistas e ajustes tributários evasivos. A investigação empírica compreendeu os anos de 2010 a 2013. A amostra foi constituída por 234 firmas, distribuídas entre 6 setores econômicos aqui definidos. Foram analisadas 846 firmas-ano. As escolhas contábeis oportunistas foram representadas pelas acumulações discricionárias, enquanto os ajustes tributários evasivos tiveram como proxy as diferenças contábil-tributárias anormais. Por meio de regressões com base na média condicional e quantílica, verificou-se que, no cenário brasileiro, a probabilidade de detecção tributária restringe as escolhas contábeis oportunistas sobretudo nos níveis mais elevados da distribuição dessas escolhas. Entretanto, as evidências são condicionadas ao tipo de decisão teórica e se mostraram mais contundentes para as firmas submetidas ao acompanhamento econômico-tributário diferenciado, realizado pela Secretaria da Receita Federal do Brasil, uma vez que tais firmas demonstraram maior sensibilidade ao risco de detecção, tanto em relação às escolhas contábeis quanto aos ajustes tributários totais. As constatações realizadas sugerem que, em algumas situações, os agentes seriam capazes de obter ganhos privados por meio de escolhas contábeis oportunistas, por isso a sensibilidade à governança tributária.

Palavras-chave: Evasão tributária. Probabilidade de detecção tributária. Escolhas contábeis oportunistas. Teoria de agência. Governança tributária. 


\begin{abstract}
In an agency environment, tax evasion may represent an additional mechanism for the exercise of managerial opportunism, so that the tax enforcement acts as an external instrument of governance "at the disposal" of the firm. This is the central idea of this work, whose objective was to investigate the effect of tax detection probability associated with taxation on income of Brazilian publicly traded firms. For this purpose, a theoretical an analytical framework was developed, based on which have been proved theoretical propositions that supported the research hypothesis. In this analysis, it has considered four decisions related to tax evasion, which involved opportunistic accounting choices and evasive tax adjustments. Empirical research covers the years 2010 to 2013. The sample consisted of 234 firms, distributed between 6 herein defined economic sectors. A total of 846 firms-year were analyzed. Opportunistic accounting choices were represented by discretionary accrual, while evasive tax adjustments proxy was abnormal book-tax differences. Using regressions based on conditional mean and quantile regression, it was found that, in the Brazilian context, the tax probability of detection restricts opportunistic accounting choices especially at the highest levels of the distribution these choices. However, the evidence is conditioned to the type of theoretical decision and were more stronger for firms subject to differentiated economic-tax monitoring, conducted by the Secretariat of Federal Revenue of Brazil, since firms showed greater sensitivity to risk detection, in relation to the accounting choices and to the total tax adjustments. These results suggest, that in some situations, agents would be able to get private benefits by opportunistic accounting choices, so the sensitivity to the tax governance.
\end{abstract}

Keywords: Tax evasion. Tax detection probability. Opportunistic accounting choices. Agency theory. Tax governance. 


\section{LISTA DE FIGURAS}

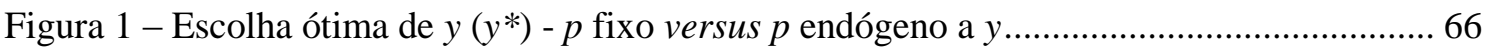

Figura 2 - Decisão do agente - Oportunismo Gerencial versus Evasão Tributária..................... 78 


\section{LISTA DE TABELAS}

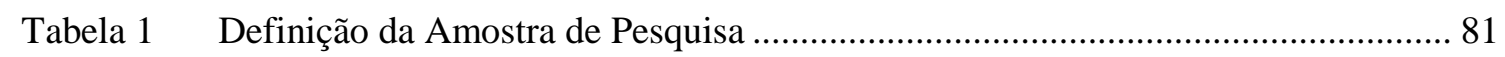

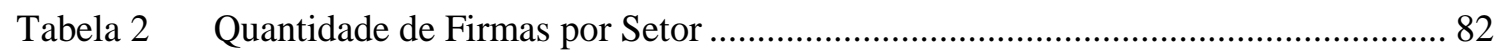

Tabela 3 Quantidades de Auditorias Encerradas e Quantidades de Firmas - 2010 a 2013... 95

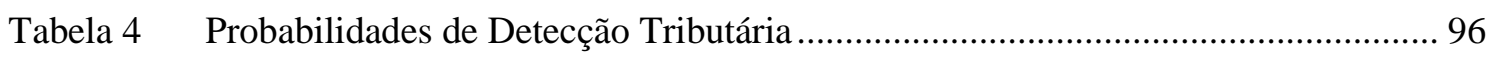

Tabela 5 Estatísticas Descritivas - Variáveis do Modelo Jones Modificado ........................ 101

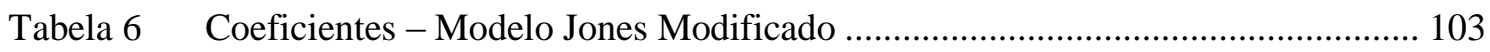

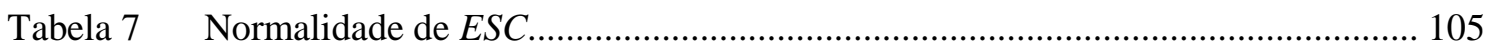

Tabela 8 Estatísticas Descritivas - Variáveis da equação (38)........................................... 106

Tabela 9 Matrizes de Correlação - Pearson (parte inferior) e Spearman (parte superior).. 109

Tabela 10 Estimações Setoriais das DCT normais - equação (38)...................................... 113

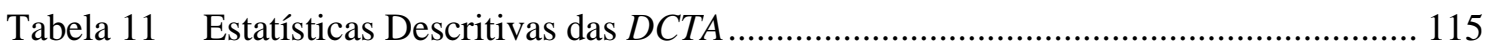

Tabela 12 Estatísticas Descritivas - Variáveis das equações (32) e (33) ............................... 116

Tabela 13 Médias Intra-Quantis - Variáveis das equações (32) e (33).................................. 117

Tabela 14 Matrizes de Correlação - Pearson (parte inferior) e Spearman (parte superior).. 119

Tabela 15 Endogeneidade entre ESC e DCTA - Resultados dos Testes de Hausman

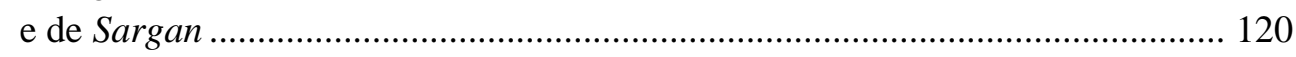

Tabela 16 Resultados para a Probabilidade de Detecção Tributária - Equação (32) ............. 121

Tabela 17 Resultados para a Probabilidade de Detecção Tributária - Equação (33): variável dependente DCTA ................................................................................. 129

Tabela 18 Resultados para a Probabilidade de Detecção Tributária - Equação (33): variável

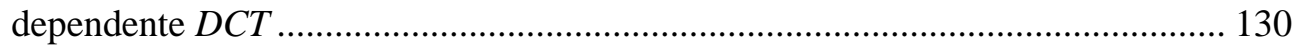

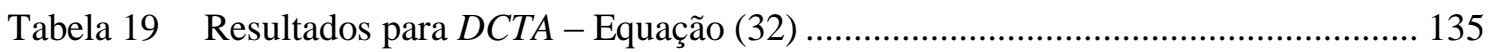

Tabela 20 Resultados para a Amostra Total - Equação (32)................................................ 166

Tabela 21 Resultados para a Decisão 1 - Equação (32) ....................................................... 167

Tabela 22 Resultados para a Decisão 2 - Equação (32) ........................................................ 168

Tabela 23 Resultados para a Decisão 3 - Equação (32) ........................................................... 169

Tabela 24 Resultados para a Decisão 4 - Equação (32)......................................................... 170

Tabela 25 Presença de Investidores Institucionais (GOVERN) - Equação (34).................... 171

Tabela 26 Adesão aos Segmentos de Governança Corporativa da BM\&FBovespa

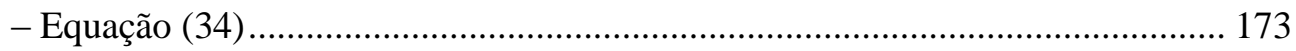

Tabela 27 Resultados para a Amostra Total - equação (33): variável dependente DCTA ... 174

Tabela 28 Resultados para a Decisão 1 - equação (33): variável dependente DCTA............ 176

Tabela 29 Resultados para a Decisão 2 - equação (33): variável dependente DCTA............ 177 


\section{LISTA DE TABELAS}

Tabela 30 Resultados para a Decisão 3 - equação (33): variável dependente DCTA............ 178

Tabela 31 Resultados para a Decisão 4 - equação (33): variável dependente DCTA............ 179

Tabela 32 Resultados para a Amostra Total - equação (33): variável dependente DCT ...... 180

Tabela 33 Resultados para a Decisão 1 - equação (33): variável dependente DCT .............. 181

Tabela 34 Resultados para a Decisão 2 - equação (33): variável dependente DCT .............. 182

Tabela 35 Resultados para a Decisão 3 - equação (33): variável dependente DCT .............. 183

Tabela 36 Resultados para a Decisão 4 - equação (33): variável dependente DCT .............. 184

Tabela 37 Presença de Investidores Institucionais (GOVERN) - Equação (35).................... 185

Tabela 38 Adesão aos Segmentos de Governança Corporativa da BM\&FBovespa - Equação (35) ...................................................................................... 187 


\section{LISTA DE QUADROS}

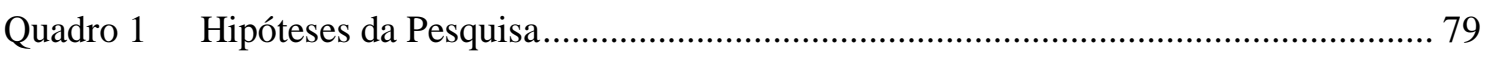

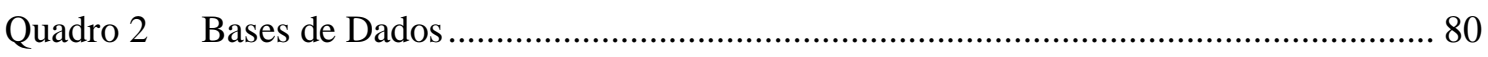

Quadro 3 Critério de Classificação das Firmas Diferenciadas ............................................... 83

Quadro 4 Variáveis das Equações (32), (33), (34) e (35) ........................................................ 84

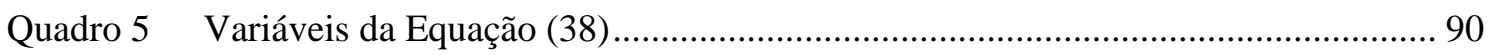

Quadro 6 Síntese das Conclusões sobre as Hipóteses da Pesquisa......................................... 137 


\section{LISTA DE EQUAÇÕES \\ (MODELOS ECONOMÉTRICOS)}

Equação (32) - Relação entre Escolhas Contábeis Oportunistas (ESC)

e Probabilidade de Detecção Tributária (Prob e Prob_Dif)

Equação (33) - Relação entre Ajustes Tributários Anormais e Totais (DCTA e DCT) e Probabilidade de Detecção Tributária.................................................................. 84

Equação (34) - Relação entre Qualidade da Governança Corporativa (GOVERN), Escolhas Contábeis Oportunistas (ESC) e Probabilidade de Detecção Tributária (Prob e Prob_Dif

Equação (35) - Relação entre Qualidade da Governança Corporativa (GOVERN), Ajustes Tributários Anormais (DCTA) e Probabilidade de Detecção Tributária (Prob e Prob_Dif) 84

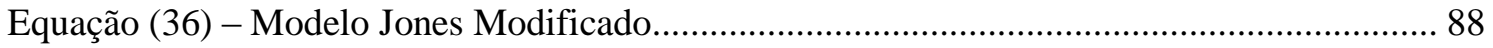

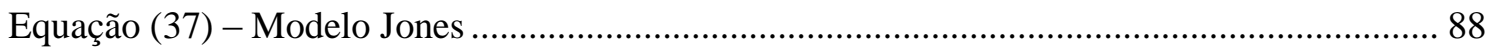

Equação (38) - Modelo de Estimação dos Ajustes Tributários Anormais (DCTA) .................... 89 
LISTA DE ABREVIATURAS E SIGLAS

$\mathrm{AD}$

AND

AT

BM\&FBovespa

CARF

COMAC

CSLL

CTN

CVM

DCT

DCTA

FCO

HMRC

IFRS

IRPJ

IRS

LAIR

MQO

MQ2E

RFB

RQ

RTT

SII
Acumulações Discricionárias

Acumulações Não Discricionárias

Acumulações Totais

Bolsa Mercantil e Futuros de São Paulo

Conselho Administrativo de Recursos Fiscais

Coordenação Especial de Maiores Contribuintes

Contribuição Social sobre o Lucro Líquido

Código Tributário Nacional

Comissão de Valores Mobiliários

Diferenças Contábil-Tributárias

Diferenças Contábil-Tributárias Anormais

Fluxo de Caixa das Operações

Her Majesty's Revenue and Customs

International Financial Accounting Standards

Imposto de Renda da Pessoa Jurídica

Internal Revenue Service

Lucro Antes do Imposto de Renda

Mínimos Quadrados Ordinários

Mínimos Quadrados em Dois Estágios

Secretaria da Receita Federal do Brasil

Regressão Quantílica

Regime Tributário de Transição

Servicio de Impuestos Internos 


\section{SUMÁRIO}

1 INTRODUÇÃO

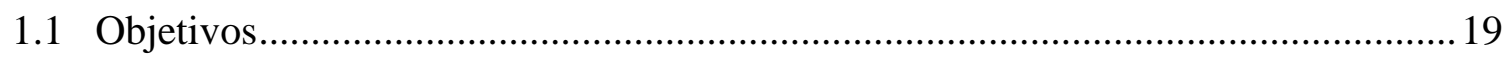

1.2 Motivação, Relevância e Caráter Inovador da Pesquisa.............................................. 19

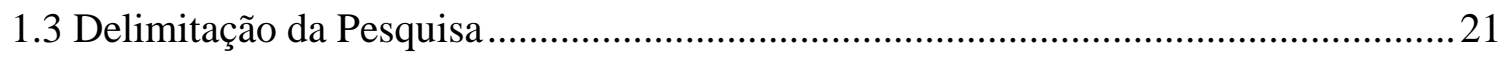

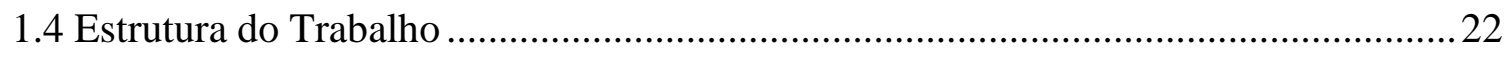

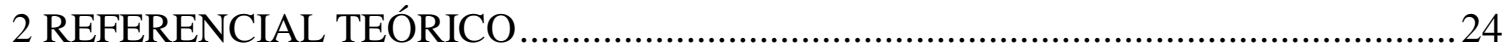

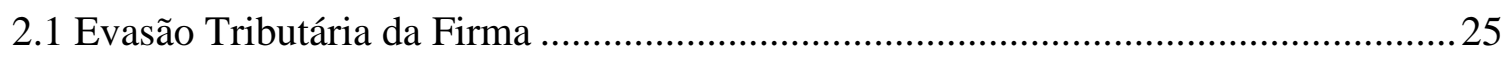

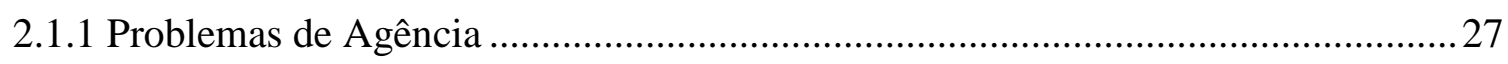

2.1.2 Contratos de Compensação e Incentivos para a Evasão Tributária...........................29

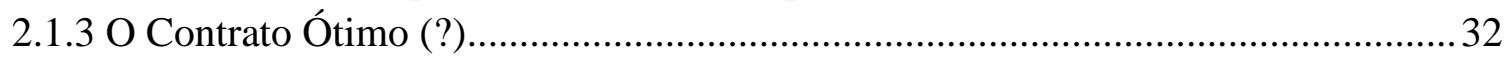

2.1.4 Qualidade da Governança Corporativa, Oportunismo Gerencial e

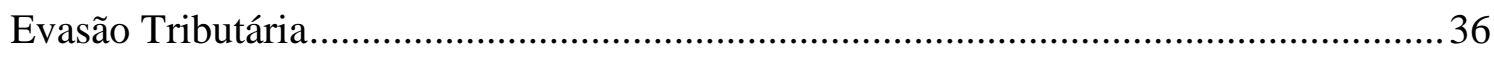

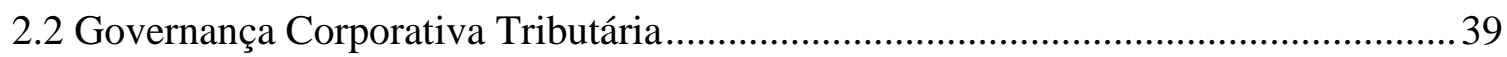

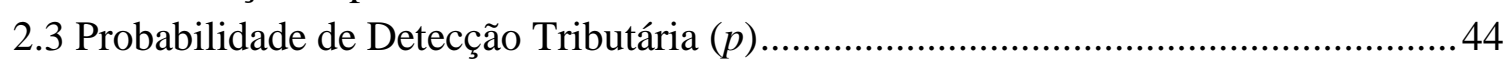

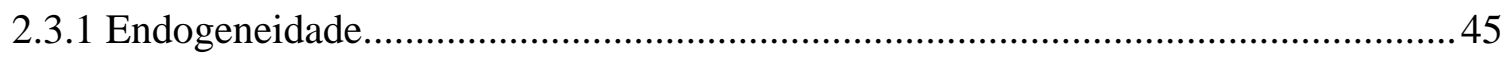

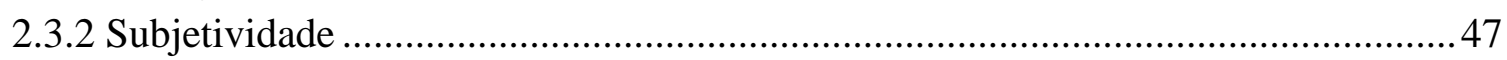

2.4 Escolhas Contábeis e Incentivos Tributários ............................................................52

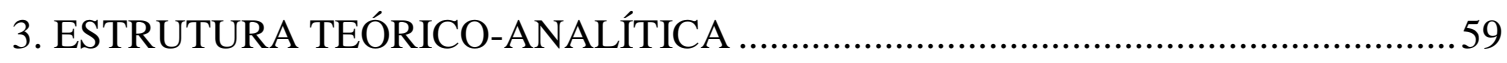

3.1 Premissas e Definições ........................................................................................59

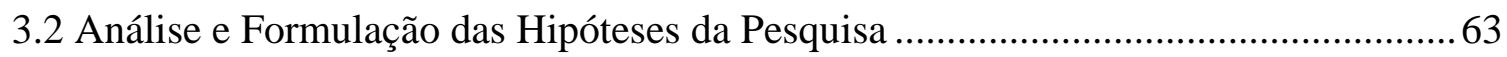

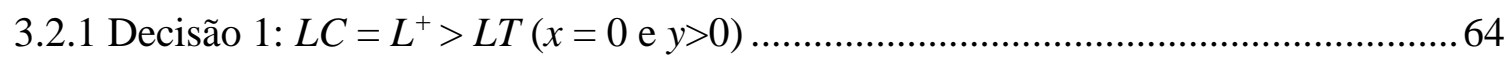

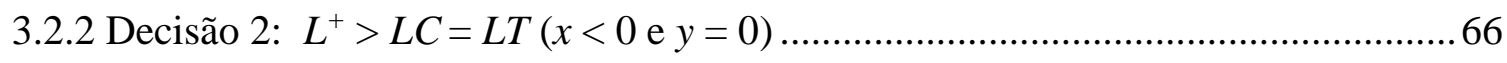

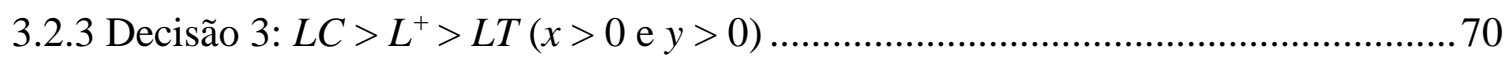

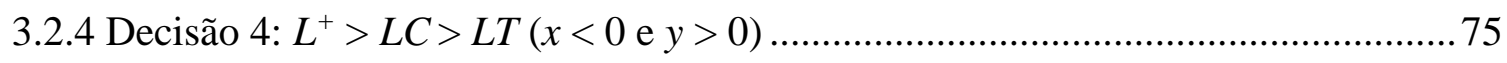

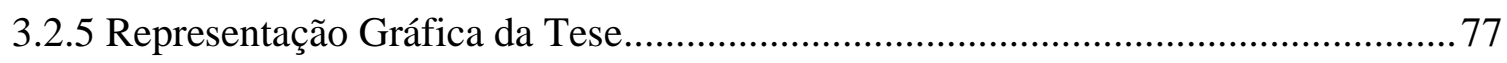

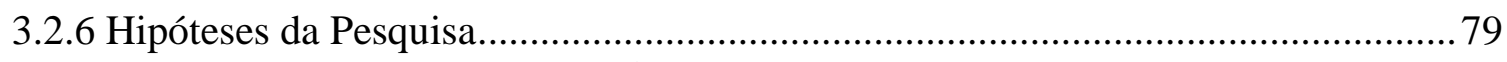

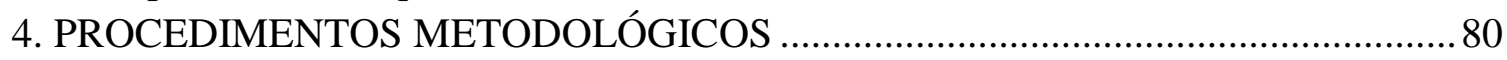

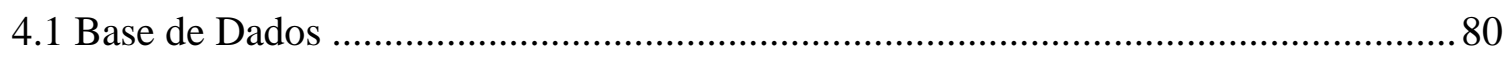

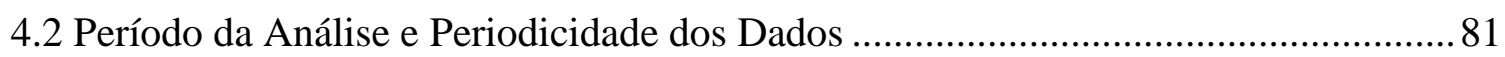

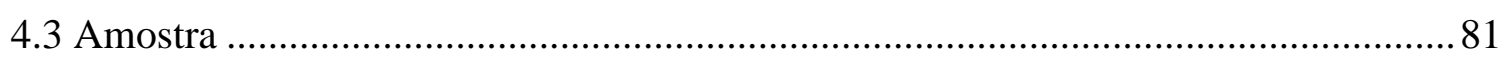

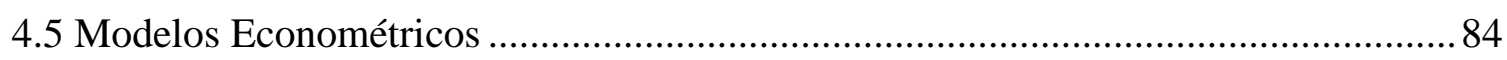

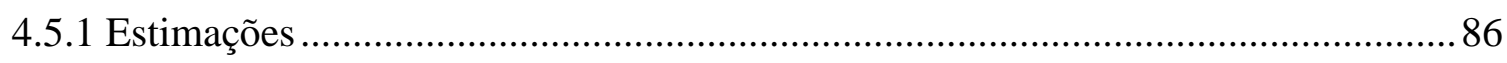

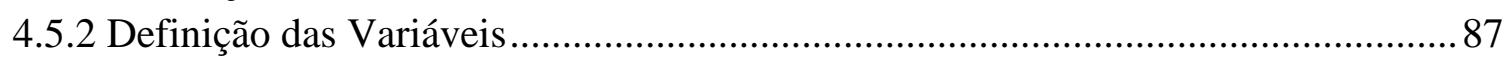

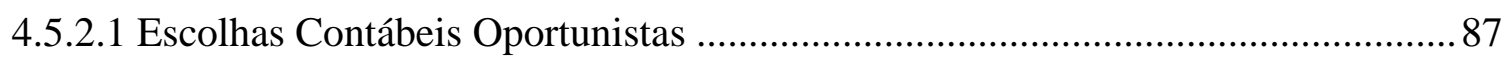

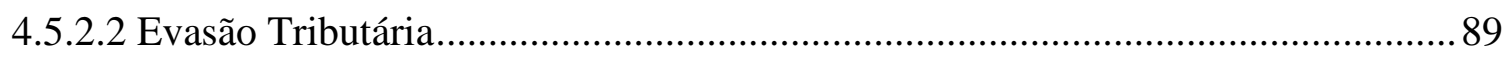

4.5.2.3 Probabilidade de Detecção Tributária …………………………………….......94

4.5.2.4 Governança Corporativa (Inv_Inst e Gov).......................................................... 97

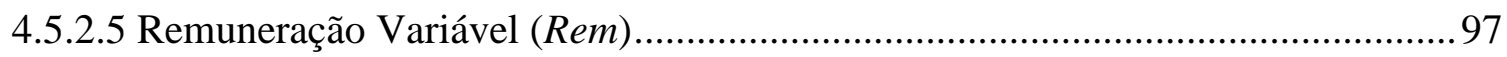

4.5.2.6 Cobertura de Analistas (Analist) .......................................................................... 98 
4.5.2.7 Qualidade da Auditoria (Big4)

4.5.2.8 Nível de Endividamento (Endv).

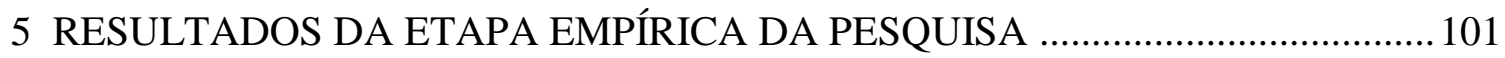

5.1 Mensuração das Escolhas Contábeis Oportunistas (ESC) .......................................... 101

5.2 Mensuração das Ajustes Tributários Anormais (DCTA) ............................................. 106

5.3 Investigação e Teste das Hipóteses da Pesquisa....................................................... 116

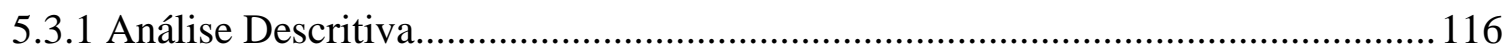

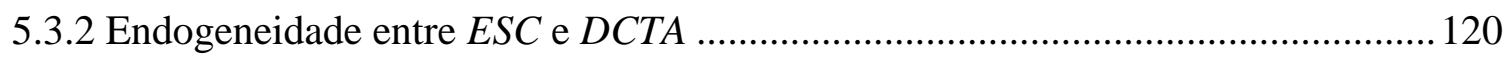

5.3.3 Probabilidade de Detecção Tributária e Escolhas Contábeis ................................ 121

5.3.4 Governança Corporativa, Probabilidade de Detecção Tributária e Escolhas

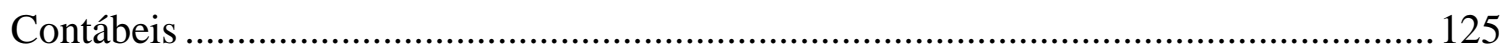

5.3.5 Probabilidade de Detecção Tributária e Ajustes Tributários.................................128

5.3.6 Governança Corporativa, Probabilidade de Detecção Tributária e Ajustes

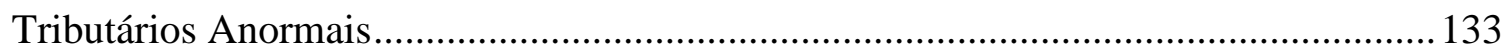

5.3.7 Inter-relação entre Escolhas Contábeis Oportunistas e Ajustes Tributários

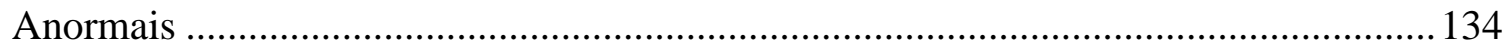

5.3.8 Síntese das Conclusões sobre as Hipóteses da Pesquisa ....................................... 137

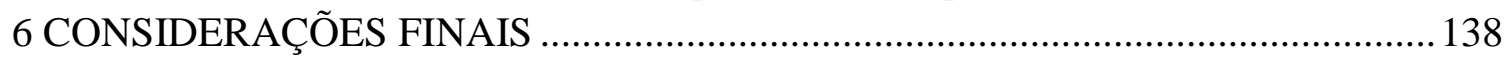

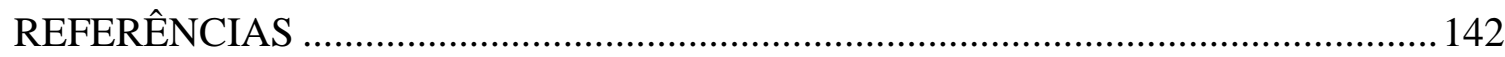

APÊNDICE A: SEMÂNTICA DA EVASÃO TRIBUTÁRIA ........................................ 161

APÊNDICE B: RESULTADOS DAS ESTIMAÇÕES DO MODELO (32) ................... 166

APÊNDICE C: RESULTADOS DAS ESTIMAÇÕES DO MODELO (34) .................. 171

APÊNDICE D: RESULTADOS DAS ESTIMAÇÕES DO MODELO (33) - Variável

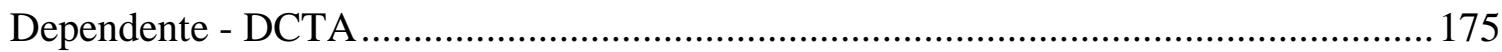

APÊNDICE E: RESULTADOS DAS ESTIMAÇÕES DO MODELO (33) - Variável

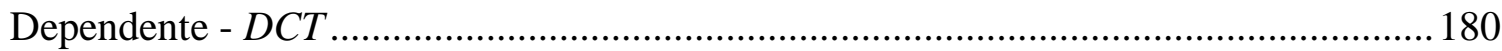

APÊNDICE F: RESULTADOS DAS ESTIMAÇÕES DO MODELO (35) .................. 185 


\section{INTRODUÇÃO}

A visão tradicional de que a evasão tributária da firma é uma transferência de riqueza do Estado exclusivamente para os seus proprietários, não é capaz de oferecer explicações satisfatórias para esse fenômeno. Isso porque, em um ambiente de agência, os arranjos contratuais tendem a ser incompletos (CHEN; CHU, 2005; CROCKER; SLEMROD, 2005), de modo que os agentes podem atuar de maneira oportunista e obter ganhos privados ao implementar estratégias tributárias evasivas (DESAI; DHARMAPALA, 2006a).

A explicação para isso advém da ideia de que essas estratégias demandam complexidade e dissimulação para evitar a sua detecção, permitindo, assim, que o agente crie novos "espaços" para atuar oportunisticamente. Igualmente, as ações oportunistas tendem a criar um ambiente mais favorável à evasão tributária. Ideia que está intimamente relacionada à ineficiência dos mecanismos de governança corporativa e ao baixo risco de detecção tributário.

A evasão tributária é aqui definida como a redução da tributação por meio de qualquer estratégia que represente uma infração à legislação tributária, de modo que, se detectada pela autoridade tributária, acarretará a imposição de uma penalidade pecuniária, independentemente da sua repercussão na esfera penal ${ }^{1}$.

O fato é que a disseminação dessa prática, por meio de estratégias complexas e sofisticadas (agressivas), tem despertado a preocupação das administrações tributárias ao redor do mundo. Muitas delas, a exemplo do Internal Revenue Service (IRS), nos Estados Unidos; do HM Revenue and Customs (HMRC), no Reino Unido; do Servicio de Impuestos Internos (SII), no Chile; e das administrações tributárias no âmbito da União Europeia, desenvolvem ações específicas para enfrentar esse problema ${ }^{2}$.

Na mesma direção, a Secretaria da Receita Federal do Brasil (RFB) tem concentrado esforços no combate ao planejamento tributário abusivo, cujo foco é as firmas que possuem maior capacidade contributiva, as quais, muitas vezes, valem-se daquele mecanismo. Ao longo dos últimos anos, mais de $60 \%$ do crédito tributário lançado nas auditorias da RFB referem-se a essa categoria de contribuintes (RFB, 2015a). Somente em relação às operações de ágio interno, por exemplo, a RFB, nos anos de 2011 e 2013, encerrou 119 auditorias cujo montante de crédito tributário lançado foi de, aproximadamente, $\mathrm{R} \$ 41,8$ bilhões (RFB, 2012, 2014).

\footnotetext{
${ }^{1}$ No Apêndice A consta uma breve discussão que fundamenta essa definição.

${ }^{2}$ Essas instituições divulgam as diretrizes da sua política fiscalizatória nas suas páginas na internet. No caso da União Europeia, essas diretrizes constam no documento Compliance Risk Management Guide for Tax Administration (EUROPEAN COMMISSION. 2010).
} 
A implementação de estratégias tributárias agressivas, assim como o seu sucesso, dependerá da eficácia do monitoramento da autoridade tributária, notadamente, da probabilidade de detecção percebida pelos agentes. A literatura tem demonstrado que esse é um fator presente e decisivo em todas as configurações assumidas para o comportamento tributário dos indivíduos e das firmas. Em resumo, aumentos na percepção de risco dos agentes tendem a reduzir a evasão tributária (ALLINGHAM; SANDMO, 1972; MARRELLI; MARTINA, 1988; WANG; CONANT, 1988; LEE, 1988; CHEN; CHU, 2010; CROCKER; SLEMROD, 2005; HOOPES; MESCALL; PITTMAN, 2012; MANHIRE, 2014; ARMSTRONG ET AL. 2015).

Nesse sentido, sob a hipótese de que a evasão tributária representa, em um contexto de agência, um mecanismo adicional para o exercício do oportunismo gerencial, o risco de detecção tributário também seria capaz de limitar a atuação oportunista dos agentes, pois, ao restringir aquela prática, reduziria as opções disponíveis para tal oportunismo. Os resultados obtidos por Desai e Dharmapala (2006a), Desai, Dick e Zingales (2007), Xu, Zeng e Zhang (2011) e Hanlon, Hoopes e Shroff (2014) alinham-se a essa dedução. Desse modo, ao assumir tal perspectiva, tem-se que a fiscalização tributária estatal atuaria como um mecanismo de governança externo "à disposição" da firma.

Sendo assim, se a probabilidade de detecção tributária é capaz de afetar o oportunismo gerencial, é possível que influencie as escolhas contábeis oportunistas realizadas pelos agentes. As constatações realizadas por Hanlon, Hoopes e Shroff (2014) sugerem que isso seria verdadeiro. Outrossim, há evidências que demonstram que o risco de detecção tributário é considerado pelos agentes quando realizam escolhas contábeis, de modo que estas podem ser consideradas como indicativos da sensibilidade do oportunismo gerencial às variações da probabilidade de detecção (CLOYD ET AL., 1996; ERICKSON; HANLON; MAYDEW, 2004; BADERTSCHER ET AL., 2009; GRAHAM ET AL., 2014).

Desse modo, a presente pesquisa investiga esse fenômeno no ambiente brasileiro, orientando-se pela seguinte questão: qual é o efeito da probabilidade de detecção tributária, associada ao Imposto de Renda da Pessoa Jurídica (IRPJ) e à Contribuição Social sobre o Lucro Líquido (CSLL), sobre as escolhas contábeis das firmas brasileiras de capital aberto? 


\subsection{Objetivos}

O presente estudo tem por objetivo geral investigar o efeito da probabilidade de detecção tributária associada ao IRPJ e à CSLL sobre as escolhas contábeis das firmas brasileiras de capital aberto.

Como objetivos específicos é possível citar:

a) Formular uma estrutura teórico-analítica, com base na teoria da utilidade econômica, para auxiliar na análise da questão de pesquisa e dos resultados obtidos na etapa empírica da pesquisa; e

b) Definir parâmetros capazes de mensurar a probabilidade de detecção tributária e as estratégias tributárias evasivas;

c) Investigar o efeito da probabilidade de detecção tributária sobre as estratégias tributárias evasivas.

d) Avaliar a interação entre os mecanismos de governança corporativa e a probabilidade de detecção tributária;

e) Analisar a inter-relação entre as escolhas contábeis oportunistas e as estratégias tributárias evasivas.

\subsection{Motivação, Relevância e Caráter Inovador da Pesquisa}

A principal justificativa à realização da pesquisa é avançar na identificação e compreensão das razões (incentivos ou restrições) que motivam as escolhas contábeis realizadas pelas firmas (agentes) no Brasil.

Muito embora há mais de trinta anos seja explorado pela literatura econômica, o tema objeto desta tese faz parte de uma linha de pesquisa relativamente recente em contabilidade em âmbito internacional e, até então, inexplorada no cenário nacional. Apesar de contar com fundamentos sólidos advindos da teoria econômica da evasão tributária e da teoria da agência, ainda não há uma estrutura teórica consolidada para o tema e o presente estudo pretende contribuir com essa construção.

No Brasil, em que pese a forte presença (interferência?) da legislação tributária na prática contábil, pesquisas tributárias em contabilidade são escassas. No que se refere ao efeito do risco de detecção tributário sobre as escolhas contábeis, até o momento, não foi encontrado nenhum estudo a respeito. É possível que este seja o primeiro, espera-se que não seja o último!

O trabalho é inovador, não só pelo seu ineditismo no cenário brasileiro, mas também porque, no enfrentamento do tema, desenvolve uma estrutura teórico-analítica, com base nos 
fundamentos da teoria da utilidade econômica, voltada especificamente para a evasão tributária, sob a qual são analisadas e demonstradas as proposições teóricas aqui formuladas, proposições que foram empregadas na avaliação dos resultados obtidos na etapa empírica do trabalho.

A relevância da pesquisa confunde-se com a sua motivação, pois, os resultados obtidos permitem avançar na identificação e compreensão das razões que motivam as escolhas contábeis realizadas pelas firmas (agentes) no Brasil. Contudo, alguns aspectos da investigação devem ser mencionados.

Sob uma perspectiva microeconômica, o estudo identifica e desenvolve, mesmo que parcialmente, dadas as limitações inerentes à investigação do tema, as relações subjacentes que atuam sobre a relação entre oportunismo gerencial e evasão tributária no âmbito da firma e os seus efeitos sobre a informação contábil, sobretudo o lucro contábil. A estrutura teórica desenvolvida representa uma importante, talvez a principal, contribuição da pesquisa, pois, oferece um caminho para a avaliação daquela relação para a definição das escolhas contábeis.

A construção de uma base teórica consistente, por si só, é um aspecto extremamente interessante e que oferece inúmeras oportunidades para o desenvolvimento de novas pesquisas, bem como, o aprimoramento de linhas de pesquisas já consideradas, até certo ponto, bastante exploradas, como é o caso do gerenciamento de resultados.

A pesquisa oferece inúmeros benefícios para os diversos agentes envolvidos em todo o processo contábil, na medida em que as escolhas contábeis afetam diretamente a qualidade da informação contábil que é divulgada e, consequentemente, a distribuição de riqueza entre os agentes econômicos. Por exemplo:

a) as entidades responsáveis pela edição dos padrões contábeis poderão identificar áreas informacionais sensíveis ao risco de detecção tributário, o que sinalizaria a possibilidade de oportunismo gerencial, e assim ampliar as exigências de divulgação;

b) os investidores, credores e entes reguladores poderão avaliar as distorções informacionais decorrentes de estratégias de evasão tributária, conforme as circunstâncias ou características verificadas, possibilitando-os aplicar suas medidas de proteção, seja pela restruturação dos contratos ou pelo aprimoramento dos mecanismos de governança corporativa, no sentido de incorporar a sensibilidade ao risco de detecção;

c) as firmas (proprietários) poderão aprimorar os arranjos contratuais com diretores e executivos (agentes) e os mecanismos de governança corporativa, no sentido de 
incorporar dispositivos que restrinjam as estratégias tributárias evasivas, dado o reflexo sobre as escolhas contábeis oportunistas;

d) o governo poderá aprimorar a sua política fiscalizatória tributária, por meio da utilização da informação contábil produzida sob o conjunto dos padrões contábeis aceitos e não, exclusivamente, sob o conjunto de regras tributárias;

e) a academia, na medida em que os aspectos aqui analisados poderão propiciar avanços teóricos e metodológicos capazes de se traduzir em novas perspectivas de pesquisa sobre o tema.

\subsection{Delimitação da Pesquisa}

Os testes empíricos realizados compreendem os anos de 2010 a 2013. Os dados possuem periodicidade anual e foram obtidos no banco de dados economática ${ }^{\circledR}$, na página na internet da Comissão de Valores Mobiliário (CVM), da Bolsa Mercantil e Futuros de São Paulo (BM\&FBOVESPA) e da RFB. Além disso, parte dos dados relacionados à probabilidade de detecção tributária foram obtidos por meio da Lei do acesso à informação.

$\mathrm{O}$ foco da pesquisa é a probabilidade de detecção tributária associada ao IRPJ e à CSLL, decorrente da atividade fiscalizatória da RFB, o que é justificado, basicamente, pelos seguintes fatores:

a) Complexidade do sistema tributário brasileiro - a existência de inúmeros tributos (impostos, contribuições etc.), com características distintas (diretos, indiretos, progressivos, regressivos etc.); dotados de campos de incidência próprios (receita, renda, circulação de mercadorias etc.); assim como de sistemáticas de apuração distintas (cumulativa, não cumulativa); instituídos e administrados sob a multidimensionalidade de entes tributantes (União, Estados, Municípios e Distrito Federal), com competências próprias para definir as suas respectivas políticas tributárias, impõem limitações metodológicas que prejudicam a realização de uma investigação que contemple a totalidade dos incentivos por eles oferecidos, uma vez que essa complexidade pode se traduzir em incentivos distintos para cada firma, os quais interagem entre si, de forma dinâmica e contínua ao longo do tempo, o que torna difícil identificar claramente os incentivos oferecidos, assim como os resultados das suas interações;

b) Representatividade e Abrangência do IRPJ e da $C S L L$ - juntos, esses tributos podem alcançar uma alíquota nominal de 34\% e, nos últimos anos, eles têm ocupado a terceira posição no ranking da arrecadação federal (RFB, 2014, 2015a). Além disso, seus campos de 
incidência contemplam, praticamente, todas as atividades econômicas exercidas pelas firmas, de modo que, com raras exceções, todas elas estão submetidas à sua tributação. Outrossim, são os tributos que recebem a maior atenção da fiscalização da $R F B$, juntos, eles têm concentrado o maior montante de créditos tributários. Somente em 2014, eles corresponderam a 49,2\% do total das autuações (RFB, 2015a).

c) Dependência da Escrituração Contábil - salvo situações específicas, a apuração das bases de cálculo do IRPJ e da CSLL tem como ponto de partida o lucro contábil, podendo, assim, exercer influência direta sobre as escolhas contábeis a serem realizadas. As evidências obtidas por Cabello (2012) corroboram essa justificativa.

Por fim, um aspecto que também merece ser destacado, refere-se às alterações promovidas no arcabouço legal do IRPJ e da CSLL, especificamente em função garantia da neutralidade tributária para a adoção dos padrões internacionais de contabilidade (International Financial Accounting Standards - IFRS). A instituição do Regime Tributário de Transição (RTT) pela Medida Provisória $n^{\circ} 449 / 2008$, esta convertida na Lei $n^{\circ} 11.941 / 2009$, e a sua extinção efetivada pela Lei $\mathrm{n}^{\circ} 12.973 / 2014$, assim como a nova formatação do ambiente político-normativo contábil brasileiro, introduzem elementos adicionais e significativos ao estudo dos efeitos dos incentivos tributários sobre as escolhas contábeis.

Contudo, tais elementos, sob a perspectiva microeconômica aqui assumida, assemelham-se a tantos outros que, ao longo do tempo, foram introduzidos na relação entre divulgação financeira e tributação, de modo que não é vislumbrada a necessidade de ajustes da formulação teórica pretendida no estudo ora proposto. Contudo, eles foram considerados no desenho metodológico da etapa empírica da pesquisa.

\subsection{Estrutura do Trabalho}

Além da presente introdução (Capítulo 1), este trabalho é constituído por mais 6 capítulos, dentre eles as referências, e por 6 apêndices.

No Capítulo 2 - Referencial Teórico - são discutidos os aspectos relacionados à evasão tributária no contexto de agência, transitando-se entre os estudos que tratam dos problemas inerentes aos incentivos contratuais de compensação, bem como às limitações para a definição de um contrato ótimo. Exploram-se também os estudos que tratam do papel da governança corporativa nesse contexto, assim como da atuação fiscalizatória tributária do Estado. 
Outrossim, a probabilidade de detecção tributária é brevemente contemplada e, por fim, são discutidos os estudos que tratam da relação entre escolhas contábeis e incentivos tributários.

A estrutura teórico-analítica utilizada para a formulação das hipóteses de pesquisa e para a análise dos resultados é desenvolvida no Capítulo 3 - Estrutura Teórico-Analítica. Nesse desenvolvimento, são apresentadas as premissas consideradas nessa estrutura, bem, como são provadas a proposições dela decorrentes. Ainda nesse capítulo, as hipóteses de pesquisa são formuladas e enunciadas.

O Capítulo 4 - Procedimentos Metodológicos - apresenta as definições e critérios de seleção da amostra da pesquisa, assim como a definição das variáveis analisadas e dos modelos econométricos utilizados.

Os resultados e as respectivas análises são apresentados no Capítulo 5 - Resultados da Etapa Empírica da Pesquisa.

Por fim, o Capítulo 6 - Considerações Finais - trata das conclusões e limitações do estudo, bem como das sugestões para pesquisas futuras. 


\section{REFERENCIAL TEÓRICO}

A evasão tributária é uma decisão sob incerteza. Nessa loteria, o jogador (contribuinte) faz a sua aposta ao omitir, da autoridade tributária, uma parcela da sua renda, sob o risco de ser detectado e penalizado.

Essa é a ideia básica subjacente do estudo seminal de Allingham e Sandmo (1972) ${ }^{3}$, sob o qual essa aposta (decisão) é analisada como um problema de alocação de carteira, em que um contribuinte avesso ao risco, visando maximizar a sua utilidade, decide sobre se e quanto da sua renda investirá no risco evasão tributária (BERNASCONI, 1998; FRAZONI, 1999; YANIV, $2009)^{4}$.

Uma das principais conclusões de Allingham e Sandmo (1972) é que aquela decisão é sensível à probabilidade de detecção tributária $(p)$ e à penalidade. Conclusão esta que tem sido compartilhada pela maioria dos estudos, cujos resultados também têm indicado que a evasão tributária é restringida por aumentos naquelas variáveis e que estas representam importantes mecanismos à disposição dos governos para o combate a esse fenômeno (SRINIVASAN, 1973; FEINSTEIN, 1991; ANDREONI; ERARD; FEINSTEIN, 1998; FRANZONI, 1999; SLEMROD; YITHZAKI, 2002; GONDIM， 2010; ANCIŪTÉ; KROPIENÉ，2010; BĂTRÂNCEA ET AL.; 2012; BIRSKYTE, 2013; MANHIRE, 2014).

A evasão tributária é um fenômeno complexo, que reúne questões que envolvem fatores sociais, culturais, psicológicos e, também, econômicos, que impõem inúmeras limitações à sua análise por meio de um modelo baseado na teoria da utilidade esperada ${ }^{5}$ (ANDREONI;

\footnotetext{
${ }^{3}$ Allingham e Sandmo (1972) é a base da literatura econômica da evasão tributária. Eles estenderam o trabalho de Becker (1968) ao estudo evasão tributária, utilizando a moderna teoria do risco desenvolvida por von Neumann e Morgenstern, o que permitiu o emprego de ferramentas econômicas na análise da obediência/conformidade tributária. (FRAZONI, 1999; SIQUEIRA; RAMOS, 2005).

${ }^{4}$ Um estudo contemporâneo a Allingham e Sandmo (1972) e digno de nota é Srinivasan (1973), o qual também propôs um modelo teórico similar e obteve conclusões semelhantes. Frise-se, no entanto, que Srinivasan (1973), adicionalmente, considerou o problema relacionado à maximização de receitas do governo e a alocação de recursos para a detecção da evasão.

${ }^{5}$ Sour (2004) argumenta que para mitigar essa deficiência, muitas perguntas deveriam ser enfrentadas, dentre elas: (1) como a honestidade e o custo da perda de reputação podem reduzir a evasão?; (2) como os sentimentos de culpa e vergonha reduzem os ganhos obtidos com a não conformidade?; (3) como a percepção quanto à justiça da legislação tributária (ou sistema tributário) e da sua aplicação (inclusive no que se refere às auditorias) podem afetar a motivação dos indivíduos para pagar seus tributos?; (4) como o grau de satisfação com o desempenho do governo pode afetar o desejo de pagar os tributos?; (5) como o comportamento tributário do grupo social no qual o indivíduo está inserido pode influenciar a sua decisão de evadir ou não? De acordo com Andreoni, Erard e Feinstein (1998), os estudos mostram que um contribuinte que deseja declarar provavelmente antecipa culpa quando avalia omitir a renda e escapar da detecção, mas provavelmente antecipa vergonha quando avalia a omissão e as consequência de ser pego. Outrossim, o contribuinte pode achar que está arcando com uma alta carga tributária, inclusive superior a outros. Além disso, pode entender que há muita gente evadindo, criando uma disparidade entre indivíduos honestos e desonestos. Em termos psicológicos, isso pode levar o indivíduo a racionalizar a evasão. Por
} 
ERARD; FEINSTEIN, 1998; SIQUEIRA, 2004; SOUR, 2004; BĂTRÂNCEA ET AL.; 2012). Contudo, apesar dessas limitações, o modelo proposto por Allingham e Sandmo (1972) ${ }^{6}$ oferece uma estrutura conceitual capaz de explicar o comportamento geral dos contribuintes, a qual será o ponto de partida para a investigação da influência da probabilidade de detecção tributária sobre as escolhas contábeis, cujos principais aspectos de interesse serão apresentados e discutidos nas próximas seções.

\subsection{Evasão Tributária da Firma}

Allingham e Sandmo (1972) e suas extensões diretas tratam da evasão tributária do imposto de renda sob a perspectiva do contribuinte pessoa física, ou seja, o indivíduo, a pessoa natural. Apesar disso, uma série de estudos, iniciada por Marrelli (1984), também desenvolveu extensões daquele modelo para analisar a evasão tributária no âmbito da firma, cuja questão central referia-se à separabilidade entre as decisões sobre os níveis de produção e de evasão tributária que maximizariam a utilidade esperada da firma. (MARRELI, 1984; MARRELI; MARTINA, 1988; WANG; CONANT, 1988; YANIV, 1995, 1996; LEE, 1998; ARIAS, 2005).

De uma maneira geral, o que se verifica nessas primeiras pesquisas é que a separabilidade depende de como $p$ e a penalidade são configurados nos modelos de utilidade esperada. A sensibilidade dos resultados a tais variáveis indica que o risco de detecção também pode influenciar as decisões das firmas sobre se e quanto evadir (LEE, 1998; BAYER; COWELL, 2009).

Lee (1998) demonstra que ao assumir $p$ fixo ou como função endógena da evasão tributária, a separabilidade se mantém. Esse é o caso de Marrelli (1984), Wang e Conant (1988), Yaniv (1995) e Yaniv (1996). Por outro lado, se $p$ é função de uma informação diferente do lucro, não haverá neutralidade e, portanto, as decisões de evasão poderão afetar as decisões de produção, tal qual visto em Virmani (1989) e Arias (2005), onde a separabilidade não se manteve em razão de $p$ ser função da produção.

\footnotetext{
outro lado, um maior desejo de conformidade dos contribuintes pode advir da percepção da correta aplicação dos valores arrecadados com os tributos, ainda mais se eles recebem diretamente parte dos benefícios oferecidos pelo governo, financiados pelos tributos.

${ }^{6}$ Uma das principais críticas sofridas por Allingham e Sandmo (1972) é que, sob seus pressupostos, considerando os níveis de probabilidade de detecção e de penalidade existentes, os indivíduos deveriam evadir muito mais do que aparentemente fazem. Esse paradoxo é chamado pela literatura como puzzle tax compliance (traduzindo livremente: enigma da conformidade tributária). Nesse ponto, a questão intrigante não é "por que as pessoas evadem tributos?", mas sim "por que as pessoas pagam os tributos?" (ANDREONI; ERARD; FEINSTEIN, 1998; BERNASCONI, 1998; FRANZONI, 1999; SLEMROD; YITHZAKI, 2002)
} 
Sendo assim, se a decisão sobre a evasão pode afetar a decisão sobre os níveis de produção que maximizam o lucro da firma, em função das características de $p$, é provável que essa variável também afete os processos de reconhecimento e mensuração de componentes do lucro (receitas e despesas) relacionados a tais níveis e, consequentemente, afete as escolhas contábeis (p.ex. adoção do PEPS ou UEPS, estimativas associadas a provisões ou perdas esperadas).

Contudo, as decisões de tributação e de divulgação financeira consideram (ou deveriam considerar) seus efeitos mútuos, de modo que estratégias de redução da tributação podem ter efeitos colaterais negativos para firma, haja vista os custos decorrentes de suas consequências sobre as demais partes contratuais que com ela interagem (SHACKELFORD; SHEVLIN, 2001; SCHOLES ET AL., 2009).

O fato é que a evasão tributária na dimensão da firma é um fenômeno mais complexo, se comparado ao contexto da pessoa física, uma vez que consiste em uma decisão estratégica tomada por uma pessoa física (agente) para evadir tributos devidos por uma pessoa jurídica (principal), em um contexto de múltiplos relacionamentos e ambientes, bem como de múltiplas partes, as quais, assim como o agente, também atuam estrategicamente (CHEN; CHU, 2005; FUKOFUKA, 2013).

Nesse sentido, parte da literatura mais recente tem demonstrado, ou pelos menos tem sugerido, que a análise da evasão tributária no âmbito da firma deve, necessariamente, incorporar os problemas decorrentes dos conflitos de agência, indicando, assim, que o modelo de Allingham e Sandmo (1972) não seria adequado para uma análise generalista nessa dimensão (CHEN; CHU, 2005; CROCKER; SLEMROD, 2005; DESAI; DHARMAPALA, 2006a, 2009a; DESAI; DYCK; ZINGALES, 2007; FUKOFUKA, 2013).

Essa visão de agência coloca em xeque a visão tradicional de que a evasão tributária seria uma mera transferência de riqueza do Estado para a firma (principal), o que traz à tona questões não enfrentadas nos primeiros estudos, dentre elas: o que leva o agente a praticar a evasão tributária? Ao implementar estratégias tributariamente evasivas, o agente busca aumentar o valor da firma ou aumentar seus ganhos privados? Como alinhar os interesses do agente aos do principal? Qual é o efeito dos custos de agência sobre a evasão tributária? Como $p$ passa a afetar a evasão tributária? Questões que estão presentes ao longo da discussão apresentada na próxima seção. 


\subsubsection{Problemas de Agência}

Evidências empíricas têm mostrado que a separação entre propriedade e controle é um aspecto significativo para o comportamento tributário das firmas. Por exemplo, as firmas de capital fechado tendem a ser tributariamente mais agressivas se comparadas às de capital aberto. Uma das explicações é que estas firmas possuiriam incentivos mais fortes para divulgação de maiores níveis de lucros, o que limitaria a redução da tributação sem ter que arcar com maiores custos de divulgação financeira ${ }^{7}$ ou sem assumir um maior risco de detecção tributário (CLOYD, 1995; CLOYD; PRATT; STOCK, 1996; MILLS, 1996, 1998; MILLS; SANSING, 2000; HANLON; MILLS; SLEMROD, 2005; HOOPES; MESCALL; PITTMAN, 2012).

Nessa linha, os resultados de Martinez e Ramalho (2014) indicam que, no Brasil, as firmas familiares ${ }^{8}$ seriam tributariamente mais agressivas, demonstrando, assim, que a estrutura de propriedade e os conflitos de agência dela decorrentes podem afetar o comportamento tributário das firmas.

Sob a visão de que a evasão tributária seria uma mera transferência de riqueza do estado para a firma, é possível conceber que agentes submetidos a contratos que ofereçam incentivos suficientes, implementem aquelas estratégias em benefício da firma, isso porque a redução da tributação aumentaria o valor desta, havendo, portanto, benefícios mútuos (DESAI; DHARMAPALA, 2009b; REGO; WILSON, 2012). Nesse sentido, os resultados obtidos por Goh et al. (2014) sugerem que os investidores perceberiam de forma positiva a adoção de estratégias tributárias menos agressivas, o que se refletiria na redução do custo de capital.

No entanto, os arranjos contratuais tendem a ser incompletos, de modo que os agentes podem agir de maneira oportunista e obter ganhos privados ao implementar estratégias tributárias evasivas (CHEN; CHU, 2005; CROCKER; SLEMROD, 2005; DESAI; DHARMAPALA, 2006a). Com isso, cria-se um cenário de maior risco em função da assimetria informacional, elevando, assim, os custos de agência (monitoramento, vinculação e perda residual) ${ }^{9}$. Sob essa perspectiva, aquelas estratégias deixam de representar uma mera

\footnotetext{
${ }^{7}$ De acordo com Shackelford e Shevlin (2001), os custos de divulgação financeira são os custos, reais ou percebidos, relacionados à divulgação de lucros mais baixos ou de um patrimônio menor. São exemplos os custos decorrentes da violação de convenants de dívidas; a redução da compensação de executivos e gerentes; e os efeitos negativos sobre o valor de mercado da firma.

${ }^{8}$ De acordo com Chen et al. (2010), firmas familiares são aquelas onde os membros da família fundadora continuam mantendo posições na alta gestão ou no conselho de diretores, ou então, são detentores de participação acionária relevante (blockholder).

${ }^{9}$ Há evidências que sugerem uma associação positiva entre a evasão tributária e o risco da firma, em função do aumento do risco tributário, de modo que, a percepção de maiores (menores) níveis de agressividade tributária, por parte dos investidores, elevaria (reduziria) o custo de capital da firma (GOH ET AL.; 2014; HUTCHENS; REGO, 2015). Guenther, Matsunaga e Williams (2013) argumentam que o nível de agressividade tributária,
} 
transferência de riqueza do Estado para a firma (DESAI; DHARMAPALA, 2006a, 2009b; GARBARINO, 2008; GOH ET AL.; 2014; HUTCHENS; REGO, 2015).

Nesse cenário, uma consequência direta é a complementaridade (efeito feedback positivo) entre o oportunismo gerencial e a evasão tributária (doravante, apenas complementaridade). A explicação para esse fenômeno parte da ideia de que as estratégias tributárias evasivas demandam complexidade e dissimulação para evitar a sua detecção, permitindo que o agente crie novos "espaços" para atuar oportunisticamente e obter benefícios privados. Do mesmo modo, as ações oportunistas tendem a criar um ambiente mais favorável à evasão tributária. Ideia que está intimamente relacionada à ineficiência dos mecanismos de governança corporativa e ao baixo risco de detecção tributário.

Haverá complementaridade se for mais fácil desviar (evadir) \$ 1 de lucro evadido (desviado) do que \$ 1 de lucro não evadido (não desviado). Assim, tem-se que transações com o fim exclusivamente tributário (oportunista) tornar-se-ão mais interessantes para o agente se puderem ser utilizadas como mecanismos para o oportunismo gerencial (evasão tributária). O resultado disso é que a redução da evasão pode levar à redução do oportunismo gerencial e vice-versa (DESAI; DHARMAPALA, 2006a; DESAI; DYCK; ZINGALES, 2007).

Um agravante para essa situação é o fato de que o agente, detendo informação privada sobre a natureza, a extensão e o alcance das estratégias tributárias a serem implementadas, faz suas escolhas sobre se e quanto evadir sem arcar com o risco de ter sua riqueza afetada em razão de uma eventual detecção (CROCKER; SLEMROD, 2005; FUKOFUKA, 2013).

Além disso, tem-se que a evasão altera a relação entre a firma e o agente, distorcendo os incentivos aos quais estes indivíduos estariam submetidos (CHEN; CHU, 2005). Sendo assim, o aspecto central sob essa perspectiva envolve, direta e necessariamente, os efeitos da natureza dos arranjos contratuais sobre os incentivos que os agentes enfrentam ao praticar a evasão tributária (CHEN; CHU, 2005; CROCKER; SLEMROD, 2005; DESAI; DHARMAPALA, 2006a).

necessariamente, não se confunde com o risco tributário da firma. Na visão deles, esse risco consistiria na volatilidade dos pagamentos dos tributos ao longo do tempo. Os resultados por eles obtidos indicam que haveria uma associação positiva entre o risco tributário e o risco da firma, o que não foi verificado em relação aos níveis de agressividade (tax avoidance e tax aggressiveness) 


\subsubsection{Contratos de Compensação e Incentivos para a Evasão Tributária}

Phillips (2003) constatou que unidades de negócios, cujos gerentes (agentes) possuíam contratos de compensação baseados no lucro após a tributação, apresentavam uma alíquota efetiva de tributação mais baixa (Effective Tax Rate - ETR), o que indicaria a realização de planejamentos tributários mais efetivos ${ }^{10}$. Resultados não observados em relação aos executivos (Chief Executive Officer - CEO).

Em Armstrong, Blouin e Larcker (2012), o objetivo foi avaliar se os incentivos oferecidos aos diretores de tributação, por meio de contratos de compensação, estariam associados com o planejamento tributário, sinalizado por: (1) menores ETR (proxies: GAAP ETR e CASH ETR); (2) maiores Diferenças Contábil-Tributárias (DCT); e (3) medidas de agressividade tributária.

Os resultados indicam que os incentivos seriam negativamente associados à GAAP $E T R^{11}$, o que seria consistente com a hipótese de que os diretores receberiam incentivos para reduzir o nível de despesa tributária reportada nas demonstrações contábeis. Uma interpretação apresentada pelos pesquisadores é que o GAAP ETR é relativamente controlável pelo diretor e pode ser mensurado com precisão suficiente de modo a torná-lo interessante para fins contratuais.

Já Gaertner (2014) constatou que os executivos respondem aos incentivos oferecidos para redução da tributação e também verificou que a compensação remuneratória recebida era positivamente associada com a utilização de medidas de desempenho pós-tributação. Para ele, essa evidência indicaria que a remuneração dos executivos também os compensaria pelos riscos adicionais assumidos com a evasão tributária.

Nesses casos, conforme argumentam Atwood et al. (2012), quando o componente variável da compensação é alto, os agentes têm incentivos para aumentar o resultado póstributação. Alinhados com isso, eles verificaram que tais incentivos influenciam o comportamento tributário das firmas frente às características do sistema tributário (efetividade da atuação fiscalizatória, nível de conformidade contábil-tributária e a tributação em bases universais $)^{12}$. Atwood et al. (2012) analisaram essa relação em 22 países, dentre eles, Austrália, África do Sul, Espanha, Estados Unidos, Índia, México, Reino Unido e Brasil.

\footnotetext{
${ }^{10}$ No estudo, um planejamento tributário é considerado efetivo quando maximiza os fluxos de caixa descontados esperados da firma, após a tributação, o que requer que os agentes considerem as consequências tributárias das suas decisões. Essa definição é dada por Scholes et al. (2009).

${ }^{11}$ Não foram encontradas associações significativas para as demais proxies.

12 Por exemplo, Atwood et al. (2012) constataram que, em países onde o componente variável da compensação é alto, a associação entre a evasão tributária e a exigência de conformidade contábil-tributária é menos negativa.
} 
As medidas de desempenho pós-tributação podem levar a ETR mais baixas, porque os agentes são motivados a considerar as consequências tributárias das suas ações, motivando-os, por exemplo, a cooperar com os especialistas tributários, no sentido de ajudar a identificar, desenvolver e executar estratégias tributárias. Tais medidas tendem a ser utilizadas por firmas que possuem mais oportunidades para a implementação de estratégias tributárias (ATTWOOD; OMER; SHELLEY, 1998; PHILLIPS; 2003; REGO; WILSON, 2012).

Por outro lado, um dos problemas dos incentivos oferecidos por essas medidas é o quão agressivas podem ser as estratégias implementadas. Isso porque, quanto mais agressivas, maiores serão as chances de oportunismo gerencial (PHILLIPS, 2003; DESAI; DHARMAPALA, 2006a, 2009b; REGO; WILSON, 2012). Para se ter ideia, Hanlon, Mills e Slemrod (2005) verificaram que há uma associação positiva entre as divergências apuradas pelo IRS (nível de agressividade) e a compensação dos executivos.

Na mesma linha, Rego e Wilson (2012) indicam que medidas baseadas no risco das ações da firma também estariam associadas com a realização de estratégias tributárias mais agressivas, pois, um maior risco tributário levaria a um maior risco da firma. Resultados semelhantes foram obtidos por Armstrong et al. (2015), que constataram uma relação positiva entre os incentivos oferecidos por tais medidas de risco e a evasão tributária, relação que se mostrou mais forte em seus níveis mais elevados.

Entretanto, os resultados obtidos por Desai e Dharmapala (2006a) sugerem que um maior alinhamento entre principal e agente, proporcionado por incentivos contratuais baseados no valor da firma ${ }^{13}$, reduziria a evasão tributária. Segundo eles, isso aconteceria porque as estratégias evasivas e os desvios gerenciais seriam complementares. Reduzindo-se estes, aquelas tenderiam a diminuir também, conforme o nível dos custos de detecção tributários envolvidos.

Uma visão alternativa à proposta por Desai e Dharmapala (2006a) é a da exaustão tributária (tax exhaustion), sob a qual aquela relação negativa se deveria aos benefícios obtidos com a dedutibilidade da compensação oferecida aos agentes, e não à complementaridade. Conforme argumentam Seidman e Stomberg (2012), essa dedutibilidade diminui os benefícios marginais da evasão tributária, por isso haveria a redução das estratégias evasivas. As evidências encontradas nesse estudo suportam essa perspectiva. Contudo, um ponto de

Eles também verificaram que nesses países, aquela característica remuneratória direciona a relação negativa entre a evasão tributária e a percepção quanto à força da atuação fiscalizatória.

${ }^{13}$ Desai e Dharmapala (2006a) consideram uma compensação baseada em opções de ações. 
discussão sobre tais resultados é que, necessariamente, eles não contrariam a ideia de complementaridade, mas sim, indicam que, na situação analisada, aqueles benefícios tributários seriam dominantes.

Já em relação às medidas de desempenho pré-tributação, tem-se que os incentivos oferecidos estariam relacionados exclusivamente à divulgação financeira. Contudo, se os agentes puderem agir oportunisticamente, haverá incentivos para pagar tributos sobre resultados "artificiais", a fim de reduzir a probabilidade de uma auditoria tributária, o que, se acontecesse, poderia revelar as práticas oportunistas implementadas. Assim, o aumento também seria utilizado como um mecanismo adicional para dissimular o oportunismo gerencial (ERICKSON; HANLON; MAYDEW, 2004; GOERKE, 2008)

Não obstante as evidências acima comentadas, os resultados obtidos por Dyreng, Hanlon e Maydew (2010) sugerem que a evasão tributária da firma é fortemente influenciada pela propensão pessoal dos executivos, de modo que os incentivos contratuais desempenhariam um papel secundário nesse processo.

Já Graham et al. (2014), em pesquisa de campo em que foram questionados em torno de 600 executivos ligados à área de tributação, constataram que a exposição pública ${ }^{14}$ de um comportamento tributário agressivo é uma preocupação relevante e representa uma das principais restrições consideradas por esses executivos na decisão sobre a evasão tributária.

Esses resultados se alinham à literatura que tem defendido que o comportamento tributário dos indivíduos também é determinado por fatores sociológicos, culturais e psicológicos (ANDREONI; ERARD; FEINSTEIN, 1998; SOUR, 2004; BĂTRÂNCEA ET AL.; 2012). Eles sinalizam os efeitos de questões morais e de aspectos idiossincráticos dos agentes sobre a evasão tributária da firma, o que tende a afetar a maneira pela qual os incentivos contratuais atuam sobre o seu comportamento.

Em toda essa discussão, o que se verifica é que não haveria uma compensação isenta de efeitos tributários “colaterais". Tendo em vista que os incentivos contratuais são mecanismos importantes para reduzir os conflitos de agência, a definição de arranjos contratuais que não ofereçam incentivos para a adoção de estratégias tributárias nocivas à firma ou que lhes imponha as restrições adequadas, surge como uma questão preliminar e demonstra ser um aspecto importante à análise do tema.

\footnotetext{
${ }^{14}$ Potenciais prejuízos à reputação da firma e o risco de atenção negativa da mídia representaram o segundo (69,5\% dos respondentes) e quarto (57,6\% dos respondentes) fatores, respectivamente, mais importantes para os executivos.
} 


\subsubsection{O Contrato Ótimo (?)}

Chen e Chu (2005) avaliam a definição de um contrato que ofereça os incentivos necessários para induzir um agente, avesso ao risco, a se engajar na evasão tributária, em um cenário onde é ele quem arca com o risco de ser detectado e penalizado. A principal conclusão desse estudo é que, nesse contexto, os contratos de compensação seriam incompletos.

Essa conclusão baseia-se no fato de que, idealmente, o agente deveria ser recompensado pelo resultado obtido com a evasão tributária (resultado pós-tributação), caso esta fosse detectada e penalizada pela autoridade tributária (autoridade). Contudo, o agente não teria instrumentos para exigir o cumprimento dessa cláusula, uma vez que ela estaria vinculada a uma prática ilegal, por isso, ele buscaria formalizar um contrato onde a sua remuneração fosse ex ante. Acontece, porém, que, nessa configuração, o pagamento da remuneração seria efetuado independentemente da detecção da evasão e, como o principal não poderia monitorar todas as ações do agente, haveria perda de eficiência do controle interno.

Entretanto, Chen e Chu (2005) argumentam que a ocorrência dessa perda dependeria, unicamente, da possibilidade de a decisão da evasão ser separada do controle do agente. Se houver tal separação, haverá duas decisões que podem ser otimizadas independentemente e, portanto, a perda não ocorreria. Caso contrário, a estratégia ótima de declaração interferirá na solução do problema agente-principal, e os incentivos do agente serão distorcidos, o que implicaria na perda de eficiência.

E é justamente este último cenário que ilustra o problema que envolve a evasão tributária e as escolhas contábeis. O fato é que muitas estratégias tributárias exploram as divergências entre a contabilidade e a legislação tributária, criando, assim, cenários favoráveis ao oportunismo gerencial. Como os contratos de compensação utilizam números contábeis como medida de desempenho, aquele oportunismo reduz o valor informacional dessa medida, daí a perda de eficiência. Esse problema recebe maior atenção em Desai e Dharmapala (2006a, 2009a, 2009b) e Desai, Dyck e Zingales (2007)

Por fim, outra constatação de Chen e Chu (2005) é que, independentemente do arranjo contratual estabelecido, a probabilidade de evasão será maior quando a probabilidade de detecção tributária e/ou a penalidade forem baixas.

Crocker e Slemrod (2005) também analisam o problema contratual da relação de agência, no contexto da evasão tributária. De acordo com as conclusões desse estudo, o contrato ótimo para reduzir a evasão tributária, ou até mesmo impedi-la, seria aquele em que as penalidades decorrentes de uma eventual detecção fossem impostas diretamente sobre os agentes. 
No modelo proposto $^{15}$, a penalidade está incorporada tanto na função de lucro do principal quanto na função de remuneração do agente. Em ambas, tal penalidade depende do nível da atuação da autoridade, que é representado pelos parâmetros $\alpha$ e $\beta$, respectivamente ${ }^{16}$.

O contrato de compensação do agente é composto por um bônus e um redutor (penalidade) que é vinculado à detecção. Sua configuração ótima é representada por uma função estritamente convexa das deduções declaradas (escolhidas) pelo agente.

Basicamente, Crocker e Slemrod (2005) demonstram que aumentos em $\alpha$ e $\beta$ reduzem a evasão, mas que $\beta$ seria mais efetivo nessa tarefa. Essa maior influência se deveria ao fato de que o agente possuiria informação privada, o que tornaria o contrato ótimo incompleto, o que se alinha à discussão apresentada por Chen e Chu (2005). Outro ponto importante demonstrado é que a compensação do agente reduziria progressivamente com aumentos em $\beta$, o que exigiria a reestruturação do contrato para oferecer bônus maiores para incentivar a evasão tributária.

É interessante notar que, em Chen e Chu (2005), o agente arca com o risco de detecção e, por isso, o contrato ótimo, apesar de incompleto, seria aquele que tal risco fosse compensado. Já em Crocker e Slemrod (2005), o contrato ótimo seria aquele em que o custo da detecção fosse imposto ao agente, já que ele não arcaria com o respectivo risco. São perspectivas diferentes de se analisar o mesmo problema, o que leva a considerações particulares. Contudo, em ambos, observa-se que o arranjo contratual tende ao ótimo quando a remuneração oferecida é vinculada ao risco de detecção.

No entanto, uma questão relevante nessa discussão é: até que ponto o agente pode arcar com o custo da evasão tributária da firma? Ou melhor: a responsabilidade legal pela evasão tributária da firma pode ser transferida para o agente? A resposta para tais questões depende das regras legais que norteiam a relação jurídico-tributária entre a firma e o Estado, as quais dependem da configuração do sistema tributário de cada país.

No Brasil, de acordo Código Tributário Nacional $(\mathrm{CTN})^{17}$, via de regra, a firma responde, na condição de contribuinte, pela obrigação tributária referente aos tributos e às

\footnotetext{
${ }^{15}$ Crocker e Slemrod (2005) consideram que: (i) o principal (shareholders) e o agente são neutros ao risco; (ii) o agente possui informação privada sobre as deduções legalmente permitidas para a apuração do tributo sobre o lucro; (iii) o agente pode se engajar em práticas evasivas, realizadas com a utilização de deduções ilegais; e (iv) o principal deseja limitar tais ações, uma vez que, se a evasão for detectada, ele (a firma) arcará com a penalidade.

${ }^{16}$ Nas funções dos shareholders e do agente são consideradas, respectivamente, as variáveis $\alpha$ e $\beta$, restritas a [0,1], as quais representam os parâmetros da atuação da autoridade ("enforcement parameters"). Tais variáveis são exógenas, no entanto, é assumido que elas são determinadas pelo nível da atividade fiscalizatória selecionado pela autoridade, o que está diretamente relacionado à probabilidade de detecção. $\beta$ representa o efeito da detecção sobre a compensação do agente.

${ }^{17}$ Lei $\mathrm{n}^{\circ} 5.172 / 1966$
} 
penalidades devidos. Entretanto, a lei pode atribuir essa obrigação a outrem (pessoa física ou jurídica), que passa a assumir o papel de responsável tributário ${ }^{18}$. Além disso, o CTN proíbe que contratos particulares, por si só, modifiquem as definições legais do contribuinte e do responsável tributário, de modo a se opor à Fazenda Pública ${ }^{19}$.

Outrossim, conforme o artigo 135, inciso III, do CTN, o agente (os diretores, gerentes ou representantes de pessoas jurídicas) somente será pessoalmente responsabilizado pela obrigação tributária da firma, se tal obrigação decorrer de atos por ele praticados com excesso de poder ou infração de lei, contrato social ou estatuto.

Já a responsabilidade pelas infrações cometidas, nos termos do art. 137 do CTN, somente será pessoal ao agente se:

a) a infração for conceituada por lei como crime ou contravenção, exceto se praticada no exercício regular de administração, mandato, função, cargo ou emprego, ou no cumprimento de ordem expressa emitida por quem de direito;

b) na definição da infração o dolo específico do agente seja elementar;

c) a infração decorra direta e exclusivamente de dolo específico;

Essas restrições legais adicionam elementos que afetam sensivelmente a definição de arranjos contratuais ótimos, conforme proposto pela literatura, no contexto brasileiro. Por exemplo, considerando a discussão de Chen e Chu (2005), como o agente somente arca com o risco de detecção em situações específicas, os contratos tenderão a se tornar ainda mais incompletos se não identificarem tais situações, uma vez que poderão oferecer um mesmo incentivo para níveis diferentes de risco.

Já sob a ótica de Crocker e Slemrod (2005), tem-se que o contrato ótimo também exigiria a identificação dessas situações, uma vez que, naqueles casos em que não houvesse a responsabilização pessoal do agente, o contrato poderia definir um mecanismo de redução da remuneração que fosse vinculado à evasão detectada. Enquanto que nos casos em que houvesse tal responsabilização, em princípio, não seria necessário prever qualquer ônus contratual, uma vez que, legalmente, o risco seria exclusivo do agente.

\footnotetext{
${ }^{18}$ Art. 128. Sem prejuízo do disposto neste capítulo, a lei pode atribuir de modo expresso a responsabilidade pelo crédito tributário a terceira pessoa, vinculada ao fato gerador da respectiva obrigação, excluindo a responsabilidade do contribuinte ou atribuindo-a a este em caráter supletivo do cumprimento total ou parcial da referida obrigação. (BRASIL, 1966)

${ }^{19}$ Art. 123. Salvo disposições de lei em contrário, as convenções particulares, relativas à responsabilidade pelo pagamento de tributos, não podem ser opostas à Fazenda Pública, para modificar a definição legal do sujeito passivo das obrigações tributárias correspondentes (BRASIL, 1966).
} 
De todo modo, um aspecto importante e que merece ser destacado é que a atuação da autoridade (parâmetros $\alpha \mathrm{e} \beta$ ), a qual possui forte vinculação com à probabilidade de detecção, é um elemento essencial na análise desenvolvida por Crocker e Slemrod (2005). Conclusão que também pode ser alcançada com base em Chen e Chu (2005). Em ambos, a probabilidade de detecção reduz a evasão tributária e tende a afetar os arranjos contratuais, o que se alinha aos estudos anteriores, desenvolvidos sob a formulação tradicional de Allingham e Sandmo (1972), a despeito do contexto contratual de agência.

Com base na discussão aqui desenvolvida, uma conclusão possível é que o agente implementará estratégias tributárias agressivas que beneficiem o principal, desde que ele seja remunerado pelo seu "sucesso" e pelo risco assumido, o que, entretanto, somente poderia ocorrer por meio de contratos ilegais e/ou incompletos. Sendo assim, ocorrendo a evasão tributária, o oportunismo gerencial será inevitável.

E é justamente com base nessa ideia que diversos estudos têm devotado esforços na investigação do efeito da governança corporativa sobre a resposta dos agentes aos incentivos de compensação, no contexto da evasão tributária, o que tem oferecido contribuições significativas (DESAI, 2005; DESAI; DHARMAPALA, 2006a, 2007; 2009a, 2009b; DESAI; DYCK; ZINGALES; 2007; ARMSTRONG ET AL., 2015).

Um exemplo é Desai e Dharmapala (2006a), cujos resultados indicaram que, de uma maneira geral, aqueles incentivos estariam associados com níveis mais baixos de evasão, mas que, no entanto, esse efeito seria mais acentuado em firmas com governança mais fraca. Eles argumentam que essas constatações sugerem que a complementaridade é uma questão significativa para a maioria das firmas analisadas, no que se refere à influência dos incentivos de compensação e dos demais mecanismos de governança. A seguir, serão discutidos os principais aspectos dessa linha pesquisa. 


\subsubsection{Qualidade da Governança Corporativa, Oportunismo Gerencial e Evasão Tributária}

No âmbito da evasão tributária, a premissa subjacente assumida é que a legislação tributária afeta a governança corporativa, cujas características, regras e mecanismos, por sua vez, afetam as estratégias de evasão dos agentes, as quais são estruturadas com base nas regras contidas naquela legislação (DESAI; DHARMAPALA, 2006a, DESAI; DYCK; ZINGALES, 2007; GARBARINO, 2008).

Devido ao feedback positivo, a redução da evasão pode levar à redução do oportunismo gerencial e vice-versa. Contudo, Desai e Dharmapala (2006a) argumentam que essa interação seria mediada pela qualidade da governança corporativa (controle interno), de modo que, em firmas com governança de maior qualidade, o impacto dos incentivos contratuais (maior alinhamento) sobre a evasão seria menor, uma vez que tais firmas já contariam com mecanismos capazes de reduzir os níveis de oportunismo. Por outro lado, em firmas com governança de baixa qualidade, esses níveis apresentariam uma resposta maior aos incentivos e, devido ao feedback positivo, a evasão também seria reduzida. Os resultados obtidos naquele estudo suportam essas proposições.

Já Desai e Dharmapala (2009a) propõem que a qualidade da governança é um importante determinante da avaliação dos efeitos da evasão sobre o valor da firma. Apesar de a redução da tributação aumentar esse valor, em firmas com governança fraca esse aumento pode ser compensado (negativamente) pelo oportunismo gerencial, o que não aconteceria nas firmas com governança forte, cujo efeito líquido sobre o valor da firma seria maior. Na análise geral desse estudo, não foi verificada uma relação significativa entre as $D C T$ e o valor da firma. Já no caso das firmas com governança forte, foi constatada uma relação positiva e significativa.

Chen et al. (2010) constataram que firmas familiares são menos agressivas tributariamente, se comparadas às não familiares. Para os pesquisadores, esse resultado indica que, em tais firmas (familiares), haveria uma maior preocupação em evitar perdas residuais (custo de agência) decorrentes da preocupação dos acionistas minoritários sobre desvios gerenciais realizados dissimuladamente com estratégias tributárias.

Na mesma linha, Lanis e Richardson (2011) e Richardson, Taylor e Lanis (2013), na Austrália, Khaoula e Ali (2012) e Boussaidi e Hamed (2015), ambos na Tunísia, e Martinez e Ramalho (2014) e Martinez, Lessa e Moraes (2014), no Brasil, apresentam evidências indicativas de que a configuração da governança corporativa e as características dos seus mecanismos afetam o comportamento tributário dos agentes. 
Martinez e Ramalho (2014) constataram que as firmas familiares seriam tributariamente mais agressivas, sinalizando, assim, o efeito estrutura de propriedade sobre o comportamento tributário das firmas. Já os resultados obtidos por Martinez, Lessa e Moraes (2014) sugerem que firmas com maiores níveis de agressividade arcariam com maiores honorários de auditoria, mas que esse custo seria minimizado pela existência de mecanismos de governança corporativa.

Entretanto, alguns estudos indicam que a governança corporativa não afetaria as estratégias de evasão tributária. Por exemplo, Hanlon, Mills e Slemrod (2005) constataram que a governança não estaria associada aos ajustes propostos pelo IRS, o que indicaria que a sua qualidade não afetaria o nível de agressividade. Rego e Wilson (2012), por sua vez, não identificaram qualquer efeito da qualidade da governança sobre a relação (positiva) entre os incentivos baseados no risco das ações e a evasão tributária. Enquanto Zemzem e Ftouhi (2013) não encontraram relação entre características do conselho de diretores e a agressividade tributária de firmas francesas.

Já Armstrong et al. (2015) constataram que a especialidade financeira e a independência dos membros do conselho estariam negativamente (positivamente) associadas à evasão tributária nos níveis mais elevados (baixos) da distribuição desta. Já em relação à qualidade da governança e à existência de remuneração baseada em opções de ações, os resultados indicaram que somente estariam associadas aos níveis mais elevados de evasão.

Esses resultados sugerem que os efeitos da governança seriam diferenciados em relação ao nível da evasão tributária, o que representa uma perspectiva mais refinada, sob a qual Armstrong et al. (2015) contestam frontalmente a ideia de complementaridade defendida por Desai e Dharmapala (2006a).

Segundo Armstrong et al. (2015), a evasão tributária seria uma das muitas oportunidades de investimento de risco disponíveis, sujeita a conflitos de agência como em qualquer outra, e que, portanto, não criaria oportunidades adicionais para desvios gerenciais. Sendo assim, o papel da governança corporativa seria mitigar os problemas de agência relacionados ao “investimento" evasão tributária, como por exemplo reduzir a exposição da firma ao risco tributário. E é sob essa perspectiva que os resultados desse estudo são analisados.

Com base em Armstrong et al. (2015), é possível assumir que os mecanismos de governança atuariam para aumentar a percepção de risco do "investimento" evasão tributária, o que se refletiria na menor propensão em empreender estratégias tributárias agressivas. Nesse cenário, é mais provável que o nível ótimo de evasão se dê em uma solução interior. Essa visão aproxima-se da originalmente desenvolvida por Allingham e Sandmo (1972), onde a evasão 
consiste em um problema de alocação de carteira, isto é, de investimento, em que o contribuinte deve decidir, sob incerteza, sobre qual parcela de sua renda quer investir na evasão.

Apesar de os resultados apresentados por Armstrong et al. (2015) se ajustarem à sua proposta teórica, eles, necessariamente, não refutam por completo a ideia de complementaridade. O fato é que, ao replicar as estimações de Desai e Dharmapala (2006a) sob a sua metodologia (regressão quantílica), Armstrong et al. (2015) somente encontraram resultados semelhantes aos daquele estudo nos níveis mais altos de agressividade, o que, segundo eles, seria uma evidência contra a complementaridade.

No entanto, como Armstrong et al. (2015) não avaliaram o efeito dos custos da evasão (por exemplo, os níveis de $p$ ) sobre a agressividade tributária, não é possível afastar a hipótese de que tais custos, nos níveis mais baixos de agressividade, teriam sido suficientemente pequenos, a ponto de reduzir, ou até mesmo anular, o feedback positivo entre evasão e oportunismo gerencial e, por isso, os incentivos gerenciais oferecidos não teriam sido adequados, explicação que pode ser obtida com base em Desai e Dharmapala (2006a).

Os estudos aqui apresentados analisam, basicamente, a relação entre a governança e o comportamento oportunista dos agentes (tributário e gerencial), no ambiente interno da firma. No entanto, a interação entre a configuração da governança corporativa e as características do sistema tributário (alíquota, probabilidade de detecção, penalidade etc.) é um elemento que se revela essencial à análise da evasão tributária no âmbito da firma, pois, tendo em vista a complementaridade, a autoridade não buscaria apenas reduzir a evasão, mas também estaria interessada em reduzir os desvios gerenciais, por isso a sua atuação poderia ser influenciada pela qualidade da governança, ao tempo em que esta seria aprimorada pela atuação estatal. Essa perspectiva é chamada de Visão de Governança Corporativa da Tributação ${ }^{20}$ (DESAI, 2007; DESAI; DICK; ZINGALES, 2007) e será discutida a seguir.

\footnotetext{
20 Tradução livre: Corporate Governance View of Taxation
} 


\subsection{Governança Corporativa Tributária}

O Estado, na sua atividade tributária, é uma parte contratual importante (mas, talvez, indesejada) que interage com a firma e que, assim como outros interessados (investidores, gerentes, credores etc.), participa dos seus resultados. Contudo, essa é uma relação "contratual" (relação jurídico-tributária) diferenciada, uma vez que é estabelecida em lei e, por isso, a firma, em princípio $^{21}$, teria pouca, ou nenhuma, participação na definição das regras que regem tal relação (sistema tributário).

As características do sistema tributário, notadamente, a tributação em si (campo de incidência, complexidade, alíquotas) e o nível de monitoramento (probabilidade de detecção, efetividade, penalidades, fornecimento de informações etc.), tendem a influenciar o relacionamento principal-agente, no âmbito da firma, enquanto a natureza desse relacionamento, delineada pela qualidade da governança corporativa, por sua vez, influenciara a efetividade da aplicação das regras do sistema tributário. Sob esse enfoque, a redução do oportunismo gerencial seria um objetivo compartilhado pelos proprietários da firma e pela autoridade, desse modo, uma questão central para a governança corporativa tributária também seria a redução dos problemas de agência (DESAI; DHARMAPALA, 2008; DESAI; DICK; ZINGALES, 2007).

Igualmente às outras partes, o Estado (representado pela autoridade tributária) tem interesse em coibir a realização de quaisquer práticas que reduzam os tributos que lhe são devidos, dessa forma, estabelece mecanismos de monitoramento a fim de avaliar a exatidão do lucro objeto da tributação, o qual é apurado conforme as regras contidas no sistema tributário. As "violações contratuais" identificadas (infrações tributárias) podem ser penalizadas com multas e, até mesmo, com sanções de natureza penal (prisão, serviços à comunidade, multa etc.), sem que isso venha a extinguir a relação jurídico-tributária. Sempre que a atividade da firma se enquadrar nas situações previstas em lei como fato gerador, surgirá a obrigação tributária correspondente e, portanto, estabelecer-se-á aquela relação.

Dentre tais mecanismos está a auditoria tributária, sob a qual a autoridade pode examinar registros contábeis, ativos e quaisquer documentos relacionados às atividades da firma ${ }^{22}$, e as

\footnotetext{
${ }^{21}$ Sob a teoria da regulação econômica, firmas maiores (ou setores econômicos) podem se beneficiar do processo político, uma vez que podem exercer influência sobre os políticos e burocratas, seja por meio de lobbying ou de financiamento de campanhas eleitorais (hipótese do poder político) (SALAMON; SIEGFRIED, 1977). Sendo assim, é possível que as regras "contratuais" que regem a relação jurídico-tributária entre o Estado e as firmas, possam ser influenciadas pelos interesses destas.

${ }^{22}$ No Brasil, essa prerrogativa é assegurada, em caráter geral, pelo CTN e pelo Código Civil (Lei no 10.406/2002). No CTN:
} 
obrigações tributárias acessórias, tais como declarações, escriturações, demonstrativos etc., por meio das quais a firma envia, periodicamente, informações sobre as suas atividades e sobre a apuração dos tributos. No Brasil, são exemplos dessas obrigações acessórias as escriturações no âmbito do Sistema Público de Escrituração Digital (Sped) ${ }^{23}$, tais como, a Escrituração Contábil-Fiscal (ECF), a Escrituração Fiscal Digital (Sped Fiscal) e a Escrituração Fiscal Digital das Contribuições (EFD-Contribuições).

Essa discussão lança luz sobre o modo como os incentivos tributários afetam o comportamento dos agentes, bem como evidencia um cenário de benefícios mútuos entre as governanças corporativas tributária e "tradicional". Dada a complementaridade, de um lado, o monitoramento da autoridade como principal mecanismo de governança, ao coibir as estratégias evasivas, reduziria o oportunismo gerencial, de outro, a governança da firma, ao reduzir os desvios gerenciais, restringiria a evasão tributária praticada em resposta aos incentivos oferecidos pelo sistema tributário.

Por exemplo, é esperado que, ceteris paribus, as receitas tributárias do Estado, decorrentes de um determinado tributo, respondam positivamente a aumentos na alíquota deste.

Art. 195. Para os efeitos da legislação tributária, não têm aplicação quaisquer disposições legais excludentes ou limitativas do direito de examinar mercadorias, livros, arquivos, documentos, papéis e efeitos comerciais ou fiscais, dos comerciantes industriais ou produtores, ou da obrigação destes de exibilos.

Parágrafo único. Os livros obrigatórios de escrituração comercial e fiscal e os comprovantes dos lançamentos neles efetuados serão conservados até que ocorra a prescrição dos créditos tributários decorrentes das operações a que se refiram.

Já no Código Civil:

Art. 1.193. As restrições estabelecidas neste Capítulo ao exame da escrituração, em parte ou por inteiro, não se aplicam às autoridades fazendárias, no exercício da fiscalização do pagamento de impostos, nos termos estritos das respectivas leis especiais. (BRASIL, 2002)

De forma específica, no âmbito da tributação federal, tem-se a Lei no 10.593/2002:

Art. $6^{\circ}$ São atribuições dos ocupantes do cargo de Auditor-Fiscal da Receita Federal do Brasil:

I - no exercício da competência da Secretaria da Receita Federal do Brasil e em caráter privativo:

d) examinar a contabilidade de sociedades empresariais, empresários, órgãos, entidades, fundos e demai s contribuintes, não se lhes aplicando as restrições previstas nos arts. 1.190 a 1.192 do Código Civil e ob servado odisposto no art. 1.193 do mesmo diploma legal;

${ }^{23}$ O Sistema Público de Escrituração Digital (Sped) foi instituído pelo Decreto no 6.022/2007. De acordo com o art. $2^{\circ}$ desse decreto, o Sped é um "instrumento que unifica as atividades de recepção, validação, armazenamento e autenticação de livros e documentos que integram a escrituração contábil e fiscal dos empresários e das pessoas jurídicas, inclusive imunes ou isentas, mediante fluxo único, computadorizado, de informações”. Seus usuários são: (i) a RFB; (ii) as administrações tributárias dos Estados, do Distrito Federal e dos Municípios, mediante convênio celebrado com a RFB; e (iii) os órgãos e as entidades da administração pública federal direta e indireta que tenham atribuição legal de regulação, normatização, controle e fiscalização dos empresários e das pessoas jurídicas, inclusive imunes ou isentas. 
No entanto, Desai, Dick e Zingales (2007) constataram que tais aumentos tiveram um menor impacto em países cujo ambiente de governança corporativa se mostrou deficiente, sugerindo, assim, que o efeito esperado sobre as receitas tributárias somente ocorreria em países com governança forte. Segundo eles, alíquotas elevadas ofereceriam incentivos maiores para a redução da tributação, criando um cenário favorável à evasão tributária e ao oportunismo gerencial $^{24}$, o qual poderia se instalar com maior facilidade naqueles ambientes deficientes.

Outros reflexos poderiam advir, por exemplo: (i) da forma como a remuneração recebida pelos agentes é tributada, o que pode afetar o contrato de compensação ótimo e, consequentemente, os incentivos oferecidos (DESAI; DHARMAPALA, 2008); (ii) da dedutibilidade ou não da remuneração compensatória paga aos agentes, o que também influenciaria os arranjos contratuais (DESAI; DHARMAPALA, 2008; ZARO, 2015); e (iii) do grau de interferência na contabilidade o que tende a distorcer as medidas de desempenho, bem como reduzir a qualidade da informação para fins de divulgação financeira, tanto pela interferência em si quanto pelo surgimento de novas estratégias tributárias que explorariam a conformidade tributária, o que também poderia criar oportunidades para desvios gerenciais (DESAI; DHARMAPALA, 2008).

Esse é um aspecto significativo e que deve ser considerado na análise comparativa de estudos que investigam a evasão tributária, uma vez que as características dos sistemas tributários dos países, assim como alterações estruturais ocorridas ao longo do tempo em um mesmo ambiente, podem afetar significativamente o ambiente de governança das firmas e a maneira pela qual os incentivos atuam sobre os agentes. ${ }^{25}$ Nesse sentido, as evidências empíricas obtidas por Atwood et al. (2012) indicam que as características dos sistemas tributários afetam as estratégias tributárias adotadas pelas firmas.

Contudo, o que se percebe, basicamente, é que o nível de tributação pode ser melhor caracterizado como um incentivo econômico visando a sua redução, ao invés de um mecanismo de governança propriamente dito. Altos níveis de tributação, ou a sua variação ao longo do tempo, podem motivar a evasão e, complementarmente, o oportunismo gerencial.

\footnotetext{
${ }^{24}$ Essa é uma questão que merece ser analisada com atenção, pois, no que se refere à evasão, caso a penalidade incida sobre o tributo evadido, tal como em Yithzaki (1974), a alíquota não teria efeito sobre o payoff da estratégia tributária implementada, uma vez que suas variações não possuem efeito substituição. Aumentos na alíquota podem levar a diminuições na evasão, caso o contribuinte possua uma aversão ao risco relativo decrescente. A questão aqui é como isso funcionaria no âmbito da firma, em uma configuração em que há complementaridade. Aparentemente, a hipótese inicial é que os ganho privados advindos do oportunismo afetariam o payoff da evasão.

${ }^{25}$ Atwood et al. (2012) argumentam que a compreensão do impacto das características do sistema tributário sobre a evasão tributária das firmas mostra-se relevante para os governos, pois contribui com a definição do próprio sistema tributário, assim como para os investidores, uma vez que os auxiliará na interpretação das diferenças do comportamento tributário das firmas entre os países.
} 
Por outro lado, a implementação de práticas evasivas dependerá da eficácia do monitoramento da autoridade, notadamente, da probabilidade de detecção tributária $(p)$ percebida pelos agentes. E é esse o principal mecanismo de governança tributária. Seja qual for a perspectiva considerada, a literatura tem demonstrado que $p$ é um fator presente e decisivo em todas as configurações assumidas para o comportamento tributário dos indivíduos e das firmas (ALLINGHAM; SANDMO, 1972; MARRELLI; MARTINA, 1988; WANG; CONANT, 1988; LEE, 1988; CHEN; CHU, 2010; CROCKER; SLEMROD, 2005; DESAI; DHARMAPALA, 2006a; ARMSTRONG ET AL. 2015).

Para ilustrar esse argumento, tem-se que, sob formulação teórica proposta por Desai e Dharmapala (2006a), os incentivos contratuais de compensação reduziriam a evasão tributária, o que seria mais acentuado em firmas com governança deficiente. No entanto, essa hipótese somente será válida se os custos com a evasão enfrentados pelos agentes forem elevados. Portanto, a questão é que, se o risco de detecção for baixo, a complementaridade poderá não existir. Noutro extremo, ao assumir que a evasão é uma oportunidade de investimento, cuja decisão sujeita-se à incerteza, Armstrong et al. (2015) também assumem que o risco de detecção é um fator relevante para tal decisão.

Desai, Dick e Zingales (2007) modelam a decisão do agente quanto ao nível ótimo dos desvios gerenciais e demonstram o impacto da tributação e do risco de detecção sobre essa decisão. Segundo eles, esse risco terá mais chances de reduzir o oportunismo gerencial se: (i) a governança da firma for fraca; (ii) houver menor concentração de propriedade; e (iii) a alíquota de tributação for baixa ${ }^{26}$.

De toda essa discussão, extrai-se que a governança corporativa tributária restringe o oportunismo gerencial, mitigando, assim, os problemas de agência da firma. Dessa forma, o nível de monitoramento tributário adicional, mais especificamente, o nível de $p$ percebido pelos agentes, contribuiria com o aumento do valor da firma, com a redução do seu custo de capital e com qualidade da informação contábil, além do efeito esperado sobre a evasão tributária. Essas hipóteses têm sido testadas e as evidências empíricas obtidas têm demonstrado essas associações existiriam.

Desai, Dick e Zingales (2007) analisaram o caso da Rússia e constataram que o aumento do risco de detecção no setor petrolífero, ocorrido no início da década de 2000, logo após a

\footnotetext{
${ }^{26}$ Entretanto, um ponto que não é enfrentado por Desai, Dick e Zingales (2007) é o efeito do grau de aversão ao risco do agente. É possível que o efeito da governança tributária sobre $d$ seja modificado conforme o agente apresente aversão ao risco relativo crescente, constante ou decrescente, principalmente em relação às variações de sua renda em função de alterações na alíquota.
} 
eleição do presidente Putin, contribuiu com o aumento do valor de mercado das firmas monitoradas, bem como reduziu o valor do respectivo prêmio de controle, mesmo havendo o pagamento adicional de tributos.

Em linha com essa visão, Xu, Zeng e Zhang (2011) constataram que o risco de detecção reduziu os custos de agência entre shareholders e gerentes; e entre blockholders e minoritários, enfrentado por firmas chinesas, especialmente naquelas controladas pelo Estado. Nesse estudo foram consideradas 35 regiões da China, as quais possuem características particulares em relação à detecção, o que é um aspecto positivo.

Outro ponto é que, apesar de Xu, Zeng e Zhang (2011) argumentarem que adotam uma perspectiva diferente da proposta por Desai, Dick e Zingales (2007), uma vez que analisam o risco de detecção como um mecanismo adicional de governança, sem considerar a sua interação com a governança corporativa, os seus resultados sugerem que essa diferença não seria tão grande, pois há a indicação de que o risco de detecção reduz os conflitos de agência, e isso afetaria o ambiente de governança das firmas chinesas.

Guedhami e Pittman (2008) verificaram uma associação negativa entre $p$ e o custo da dívida de firmas de capital fechado. Esse efeito se mostrou mais acentuado para aquelas com níveis mais altos de concentração de propriedade. Resultados semelhantes foram obtidos por El Ghoul, Guedhami e Pittman (2011) em relação ao custo do capital próprio para as firmas de capital aberto, inclusive no que se refere ao maior impacto em firmas com governança deficiente. Esses resultados sugerem que a redução da assimetria informacional, e a consequente redução do risco da firma, teria sido o principal benefício da governança tributária.

Já Hoopes, Mescall e Pittman (2012) encontraram evidências indicativas de que $p$ restringe a evasão tributária e que seu impacto foi maior em firmas com governança de baixa qualidade. Segundo eles, isso sugere que tais firmas seriam mais sensíveis ao risco de detecção, pois, dada a deficiência na governança, os agentes teriam maior liberdade para atuar de forma oportunista por meio das estratégias tributárias.

Hwang (2013), por sua vez, encontrou uma associação negativa entre $p$ e a probabilidade de republicação das demonstrações contábeis de firmas estadunidenses. Esse resultado reforça a ideia da governança tributária e sugere que esse mecanismo contribuiria com a qualidade do relatório financeiro.

Por fim, Hanlon, Hoopes e Shroff (2014) verificaram que $p$ é positivamente associado à qualidade das acumulações contábeis e é negativamente associado às acumulações discricionárias, indicando também que a governança tributária afeta positivamente a qualidade do relatório financeiro. Entretanto, esses efeitos dependeriam da qualidade dos mecanismos de 
governança corporativa da firma. Eles verificaram que o impacto de $p$ seria mais fraco em firmas com governança mais forte, uma vez que, em tais firmas, os desvios gerenciais já estariam submetidos a um nível satisfatório de monitoramento.

Conjuntamente, essas constatações reforçam a ideia da efetividade da governança corporativa tributária como mecanismo de controle adicional à governança corporativa e, indiretamente, evidenciam a complementaridade.

\subsection{Probabilidade de Detecção Tributária $(p)$}

No jogo da evasão tributária, a ideia mais básica da relação econômica entre a autoridade e o contribuinte é que, de um lado, o problema enfrentado por este é a escolha de um nível de declaração que maximize a sua utilidade esperada, de outro, o problema daquele é a escolha de nível ótimo de $p$ (e/ou penalidade), sujeito às suas restrições orçamentárias e ao seu entendimento das respostas dos contribuintes, que maximize a sua receita líquida esperada (SRINIVASAN. 1973; POLINSKY; SHAVELL, 1979; GRAETZ; REINGANUM; WILDE, 1986; EUROPEAN COMMISSION, 2010; RABLEN, 2014).

Em Allingham e Sandmo (1972), e em suas extensões diretas, $p$ é considerado fixo, de modo que todos os contribuintes teriam igual chance de ser fiscalizados. Entretanto, apesar dessa definição ter sido útil do ponto de vista teórico, ela não é realística e é uma das limitações presentes nesse modelo que tem sido, ao longo do tempo, objeto de críticas e motivação para muitos estudos (REINGANUM; WILDE, 1985, 1986; ANDREONI; ERARD; FEINSTEIN, 1998; FRANZONI, 1999; ALM, 1999; SLEMROD; YITHZAKI, 2002; LITAN; VÂJU, 2008; ANCIŪTĖ; KROPIENE், 2010; GONDIM, 2010; MANHIRE, 2014)27.

Dessa problemática, a endogeneidade de $p$ e a forma como os indivíduos o percebem (subjetividade) são dois pontos que apresentam especial interesse neste trabalho, os quais serão tratados a seguir.

\footnotetext{
${ }^{27}$ É importante destacar que a dependência de Prob foi brevemente discutida por Allingham se Sandmo (1972), muito embora não tenha sido incorporada em seu modelo. Basicamente, ao assumir $p$ como uma função da evasão $(\mathrm{X})$, isto é, $p=p(X)$, surge a dúvida quanto ao sinal $p(X)$, ou seja, $p(X)$ seria crescente ou decrescente. Allingham se Sandmo (1972) pontuam que se a autoridade crê que os mais ricos evadiriam mais, ter-se-ia $p(X)>0$; por outro lado, se é assumido que $X$ mais baixos apresentariam uma maior probabilidade de evasão, $p(X)<0$. A-S reconheceram esta última possibilidade como uma hipótese mais natural, dentro do modelo de escolha por eles proposto, porém assumindo que $p^{\prime \prime}(X) \geq 0$. Contudo, eles demonstraram que, mesmo considerando $p(X)$, os resultados em relação à penalidade e a $p$ não mudariam, isto é, aumentos nessas variáveis reduziriam a evasão.
} 


\subsubsection{Endogeneidade}

A adoção de estratégias tributárias agressivas pelas firmas tem se mostrado um fenômeno difundido em todo mundo e representado um sério problema para as administrações tributárias. Em resposta, estas têm intensificado as suas ações no sentido de priorizar a sua atuação sobre tais situações. Por exemplo, o IRS dá atenção especial às transações e estratégias tributárias abusivas (Abusive Tax Shelters and Transaction). No combate a tais práticas, essa agência adota uma estratégia abrangente que, dentre outras ações, envolve a orientação sobre transações abusivas, a disponibilização de uma linha direta para que as firmas informem a adoção dessas transações, bem como a fiscalização específica contra aqueles que se engajam na evasão tributária ${ }^{28}$.

No âmbito da União Europeia, as administrações tributárias adotam, de maneira uniforme, o que chamam de "Gerenciamento de Risco de Conformidade" (Compliance Risk Management), cuja finalidade é viabilizar o alcance dos objetivos estratégicos dessas instituições ${ }^{29}$. Basicamente, a avaliação dos riscos consiste na análise do comportamento dos contribuintes. Quanto maior o risco de um determinado contribuinte, maior será atenção da autoridade (EUROPEAN COMMISSION. 2010).

Já no Brasil, a estratégia adotada pela RFB é priorizar a busca de ilícitos praticados por contribuintes, pessoa jurídica e pessoa física, de grande porte. A seleção e as auditorias são realizadas por equipes específicas de auditores especializados. A atuação da RFB nesse segmento de contribuintes tem sido direcionada ao combate do planejamento tributário abusivo e tem obtido resultados significativos. Para se ter ideia, em 2014, o valor das autuações sobre os grandes contribuintes totalizou $\mathrm{R} \$ 144,4$ bilhões, o que representou $71,6 \%$ do total de autuações feitas pela RFB nesse ano (RFB, 2015a,2015b).

Esse cenário indica que a autoridade tem todo interesse em diferenciar os contribuintes de acordo com o comportamento tributário verificado. Como apenas uma parte dos contribuintes pode ser auditada, a política a ser definida deverá permitir auditar diferentes contribuintes sob diferentes $p$. Como essa variável deve ser definida ex ante, seja qual for a política escolhida, é razoável assumir que $p$ dependa de outras informações previamente conhecidas, que podem ser obtidas sem que seja necessário realizar uma auditoria (ANDREONI; ERARD; FEINSTEIN, 1998; LEE, 1998).

\footnotetext{
${ }^{28}$ Essa informação está disponível em http://www.irs.gov/Businesses/Corporations

${ }^{29}$ O Gerenciamento de Risco de Conformidade consiste no processo sistemático por meio do qual a autoridade faz escolhas sobre que instrumentos pode utilizar para estimular efetivamente a conformidade tributária e prevenir os desvios, baseadas no conhecimento do comportamento dos contribuintes e relacionadas à capacidade disponível. (EUROPEAN COMMINSION, 2010)
} 
A despeito disso, o fato é que a verificação empírica da conformidade tributária enfrenta severas restrições em relação à disponibilidade de dados, de modo que a alternativa comumente adotada por diversos estudos é assumir um $p$ fixo, cuja proxy utilizada é a taxa de auditoria, a qual, geralmente, é obtida pela razão entre o número de declarações auditadas e o total de declarações apresentadas (SIQUEIRA, 2004; EL GHOUL; GUEDHAMI; PITTMAN, 2011; REITSEMA, 2012; HOOPES; MESCALL; PITTMAN, 2012; HWANG, 2013; BIRSKYTE, 2013; HANLON; HOOPES, SHROFF, 2014).

No entanto, diversos modelos teóricos têm demonstrado que, na dimensão do contribuinte pessoa física, a política de auditoria ótima para a autoridade seria aquela cujos menores níveis de renda declarada enfrentassem um maior $p$, o que requer a adoção de uma regra de auditoria em que este mecanismo seja endógeno aos valores declarados. Tais estudos assumem que a renda declarada expressaria informação sobre a renda real do contribuinte (REINGANUM; WILDE, 1985, 1986; GRAETZ; REINGANUM; WILDE, 1986; GONDIM, 2010).

A ideia de um $p$ endógeno se mantém na análise da evasão tributária da firma, independentemente de quaisquer questões relacionadas aos conflitos de agência, uma vez que a endogeneidade se dá em razão da definição da autoridade, muito embora essa característica afete a decisão do agente (MARRELLI, 1984; FUKOFUKA, 2013).

Do ponto de vista da autoridade, o lucro contábil fornece uma medida que pode ser comparada aos valores declarados, de modo que maiores $D C T$ podem contribuir com a definição do foco e do alcance da auditoria, muito embora, tais diferenças, necessariamente, não representem um sinal de agressividade tributária (MILLS, 1996, 1998; PLESKO, 2004) Nesse sentido, a literatura tem demonstrado que maiores DCT aumentam o risco de detecção ou que, pelo menos, as firmas perceberiam que isso seria possível (CLOYD; PRATT; STOCK, 1996; MILLS, 1996, 1998; MILLS; SANSING, 2000; ERICKSON; HANLON; MAYDEW, 2004; BADERTSCHER ET AL, 2009).

Os resultados apresentados por Mills $(1996,1998)$ indicam que os ajustes propostos nas auditorias do IRS são positivamente associados ao nível de DCT. Para Mills (1998), essa constatação demonstra que as firmas não podem maximizar benefícios de divulgação financeira e minimizar a tributação de forma independente, sem assumir qualquer custo, o que se alinha à hipótese de que a associação verificada naqueles estudos decorreria do trade-off entre: (1) redução da tributação corrente; (2) custos de detecção tributária; e (3) benefícios de divulgação financeira. 
Já Mills e Sansing (2000) propõem um jogo teórico para examinar o efeito das DCT sobre $p$, onde a firma e a autoridade são participantes estrategistas. Esse jogo envolve a decisão sobre escolhas tributárias e contábeis. Tem-se que, em equilíbrio, os contribuintes somente omitiriam parte das suas transações, enquanto a autoridade somente auditaria algumas delas.

Os resultados empíricos obtidos por Mills e Sansing (2000) seguem as evidências apresentadas por Mills (1996, 1998), ou seja, existe uma relação positiva entre DCT e os ajustes propostos pelo IRS. Para Mills e Sansing (2000) os dados analisados sugerem que as DCT são utilizadas pelo IRS como indicadores de transações que deveriam se sujeitar a uma auditoria.

A endogeneidade de $p$ é intuitiva e tem sido demonstrada teoricamente, além disso, ela é fortemente sugerida pela forma de atuação das administrações tributárias, as quais baseiamse na coleta sistemática de informações sobre as atividades da firma e pelo uso intensivo de recursos tecnológicos, o que seria contraditório se $p$ fosse aleatório.

Contudo, um ponto que tem sido reconhecido, porém pouco enfrentado pelos modelos teóricos e estudos empíricos é o fato de que os contribuintes possuem informação incompleta sobre os parâmetros que podem influenciar $p$, tais como, a visão que a autoridade tem sobre a renda potencial dos indivíduos e sobre como pode detectar aqueles que evadem, assim como se há recursos suficientes para realizar as auditorias. Desse modo, ao decidir se evade ou não, o contribuinte é afetado por uma probabilidade subjetiva e condicional, ao invés de uma probabilidade objetiva, tal qual é assumida nos modelos (ANCIŪTÉ; KROPIENĖ, 2010; GONDIM, 2010; MANHIRE, 2014).

\subsubsection{Subjetividade}

A literatura tem indicado que os contribuintes parecem possuir um conhecimento muito pobre e heterogêneo a respeito de $p$. Há um considerável conjunto de evidências que sugere que a maioria dos contribuintes tem apenas uma ideia aproximada da média dessa variável e de como ela responde ao nível da renda por eles declarada. (ANDREONI; ERARD; FEINSTEIN, 1998; BERNASCONI, 1998; FRAZONI, 1999; ALM, 1999; MANHIRE, 2014).

A questão é que ao decidir sobre se e quanto evadir, o indivíduo é afetado pela sua percepção em relação a $p$, ou seja, ele está submetido a uma probabilidade subjetiva, ao invés de uma probabilidade objetiva, de modo que $\bar{p} \equiv E[p()$.$] (REINGANUM; WILDE, 1985;$ ANCIŪTĖ; KROPIENE், 2010; MANHIRE, 2014).

Trata-se de uma característica bastante realista, uma vez que as regras de auditoria tendem a ser questões estratégicas para a autoridade e não são divulgadas. O que é possível, tal 
qual é verificado nos EUA e no Brasil ${ }^{30}$, por exemplo, é ter acesso aos dados referentes aos resultados das auditorias (quantidade, valores cobrados etc.) de períodos anteriores, o que pode oferecer uma ideia a respeito de $p$.

Dada a subjetividade, é factível assumir que a percepção de $p$ pode ser influenciada por inúmeros fatores, dentre eles, as características da firma (tamanho, setor de atuação, lucratividade etc.), o nível de aversão ao risco dos agentes, a complexidade da legislação tributária, a carga tributária enfrentada, as experiências anteriores com auditorias e, naturalmente, a expectativa em relação à resposta da autoridade às informações prestadas.

Quanto às experiências com auditorias passadas, por exemplo, Andreoni, Erard e Feinstein (1998) argumentam, entretanto, que tais efeitos seriam ambíguos, uma vez que auditorias menos efetivas poderiam sugerir que vale a pena evadir, enquanto aquelas com maior efetividade poderiam representar uma experiência desagradável para o contribuinte, de modo que ele passaria a desejar evadir mais e mais, na tentativa de recuperar o que "perdeu".

DeBacker et al. (2015) lançam um pouco mais de luz sobre esse assunto. Seus resultados indicam que as firmas agem estrategicamente após uma auditoria. Nos primeiros anos, elas se mostram mais agressivas, depois, aumentam o seu nível de tributação. Dentre as evidências obtidas nesse estudo, tem-se que as firmas seriam capazes de aprender com suas experiências nas auditorias e com as das outras firmas.

No que se refere à complexidade, Andreoni, Erard e Feinstein (1998) argumentam que grande parte da literatura tem assumido que todo o risco da evasão estaria na discricionariedade do contribuinte e que, sendo ele honesto, tal risco deixaria de existir. Contudo, se a legislação é vaga e ambígua, ou, por outro lado, extremamente detalhada e precisa nas suas prescrições, pode ser difícil atende-la completamente, mesmo se essa for a intenção ${ }^{31}$. O principal aspecto desse problema é que conhecer a real aplicação da legislação pode ser caro e difícil, e pode ser impossível resolvê-lo antes de uma auditoria. Sendo assim, tem-se que quanto maior a complexidade tributária, maior será a evasão. As evidências empíricas obtidas por Birskyte (2013) são consistentes com essa hipótese.

\footnotetext{
${ }^{30}$ Recentemente, a RFB passou a divulgar, no relatório "Plano Anual da Fiscalização", informações adicionais sobre o planejamento para o ano subsequente. No caso do relatório referente aos resultados de 2014, foram divulgadas informações sobre o planejamento de 2015 , dentre elas, a expectativa quanto o montante de crédito tributário a ser constituído, as principais operações que seriam objeto de fiscalização etc. (RFB, 2015).

${ }^{31}$ Estudos teóricos indicam que, talvez, a existência de algum nível de incerteza nesse sentido torne mais fácil a autoridade alcançar seus objetivos, com a redução dos custos e a elevação do risco de detecção (ANDREONI; ERARD; FEINSTEIN, 1998).
} 
A complexidade também afeta os auditores, o que leva à aleatoriedade da atuação desses agentes. Dada a complexidade, também pode ser difícil interpretar e aplicar a legislação adequadamente, assim, nas auditorias, algumas infrações podem não ser detectadas e punidas corretamente, do mesmo modo que alguns casos em que não há infração podem ser interpretados como tal e considerados indevidos (uma dedução permitida, mas que é entendida como não). (SCOTCHMER; SLEMROD, 1989; ANDREONI; ERARD; FEINSTEIN, 1998; SLEMROD, 2007). O aumento na aleatoriedade tende a elevar a percepção do risco do contribuinte. Nesse sentido, Yoon, Yoo e Kim (2011) demonstram que a possibilidade de erros nas auditorias aumenta a incerteza do contribuinte decorrente da ambiguidade da legislação.

Uma evidência mais direta, relacionada à percepção do risco de detecção, é apresentada por Cloyd et al. (1996). Nesse estudo, foi constatado que os gerentes de firmas de capital aberto estimaram um $p$ de, aproximadamente, $71 \%$, enquanto para os de firmas de capital fechado, essa estimativa foi em torno de $50 \%$. Segundo os pesquisadores, essa diferença se deveria ao fato de que as firmas de capital aberto são maiores e enfrentam um nível mais elevado de tributação, sugerindo que essas características influenciariam a percepção sobre $p$.

Essa justificativa alinha-se à ideia fundamental da hipótese dos custos políticos, sob a qual, tem-se que firmas maiores estariam sujeitas a um maior escrutínio governamental, portanto, arcariam com maiores custos políticos, dentre eles, a tributação (WATTS; ZIMMERMAN, 1978, 1986; ZIMMERMAN, 1983). Sendo assim, tem-se que em firmas maiores, dado que estas seriam politicamente mais sensíveis, os agentes poderiam superestimar $p$.

De uma maneira geral, isso encontra, mesmo que parcialmente, respaldo nas evidências advindas da psicologia (teoria dos prospectos), as quais indicam que os indivíduos não tratam a probabilidade linearmente e que há assimetria entre as preferências em relação a ganhos e perdas. Isso implica que a escolha do indivíduo seria uma função não linear e ponderada conforme a natureza dos prospectos (ganho ou perda) ${ }^{32}$, o que resulta no seguinte padrão de atitude em direção ao risco: aversão (propensão) ao risco para ganhos (perdas) de alta probabilidade e propensão (aversão) ao risco para ganhos (perdas) de baixa probabilidade (KAHNEMAN; TVERSKY, 1979; TVERSKY; KAHNEMAN, 1992)

\footnotetext{
${ }^{32}$ Kahneman e Tversky (1979) argumentam que, na teoria dos prospectos, o valor do resultado de cada opção é multiplicado por um peso atribuível à decisão. Tais pesos não são probabilidades, pois não obedecem aos axiomas da probabilidade, tampouco devem ser interpretados como graus de crenças. Eles medem o impacto dos eventos sobre o desejo relacionado aos prospectos, e não meramente a probabilidade percebida desses eventos.
} 
Tversky e Kahneman (1992) constataram que os indivíduos superestimam $p$ em seus níveis mais baixos e que o subestimam nos seus níveis médio e mais elevados, independentemente da natureza dos prospectos (os resultados para ganhos e perdas foram muito próximos), o que é suportado, mesmo que parcialmente, pelas evidências empíricas apresentadas por Carmerer e Ho (1994) e Wu e Gonzales (1996).

No caso da evasão tributária, as evidências indicam que a probabilidade de detecção é superestimada (BERNASCONI, 1998; ANCIŪTĖ; KROPIENĖ, 2010). Sob esse argumento, Bernasconi (1998) discute sobre dois tipos de aversão ao risco experimentada pelos indivíduos. Na aversão de ordem 1, o contribuinte enfrentaria $p$ e não evadiria se o payoff esperado não fosse tão grande. Já na aversão de ordem 2, ele sempre evadiria, bastando apenas que o payoff esperado da evasão fosse positivo.

Para Andreoni, Erard e Feinstein (1998), há consistência entre o senso de uma obrigação moral para ser honesto e a tendência de superestimar a chance de ser pego. Talvez, como consequência, uma alta probabilidade de detecção subjetiva esteja significativamente associada com um comportamento mais "honesto".

Nesse ponto, vem à tona toda a discussão proposta por Sour (2004), em relação à influência de fatores sociológicos, culturais e psicológicos sobre o comportamento tributário dos indivíduos. Por exemplo, na dimensão cultural, Bame-Aldred et al. (2013) analisaram 31 países, dentre eles, o Brasil, e constataram que as firmas em países cuja sociedade é marcada pelo individualismo e por um menor grau de orientação humana se engajaram em maiores níveis de evasão tributária.

Outro exemplo é Graham et al. (2014), cuja conclusão é que a exposição pública de um comportamento tributário agressivo é uma preocupação relevante para os executivos, representando, assim, um dos principais incentivos para limitar a adoção de estratégias tributárias agressivas. Potenciais prejuízos à reputação da firma e o risco de atenção negativa da mídia foram o segundo (69,5\% dos respondentes) e quarto (57,6\% dos respondentes) fatores, respectivamente, mais importantes para os executivos.

No entanto, nessa pesquisa, o principal motivo apontado para a não adoção de uma estratégia tributária é a falta de propósito negocial ou falta de substância econômica da transação objeto dessa estratégia (86\% dos respondentes). De acordo com os autores, isso se deveria à baixa expectativa de sucesso dessas estratégias, tendo em vista que o IRS frequentemente nega benefícios tributários para transações que se apresentam tecnicamente dentro da lei, mas que violaria o propósito desta. 
O fato é que, apesar de não discutido no artigo, tem-se que essa preocupação maior relaciona-se, diretamente, com o risco de detecção, uma vez que o questionamento sobre o propósito ou essência das transações se dá no âmbito da atuação do IRS. Se não houver fiscalização, provavelmente não existirá esse questionamento. Essa relação também pode ser estendida à exposição pública, pois, é possível que quanto maior o risco de detecção, maiores seriam as chances de uma possível exposição. Isso revela que o risco de detecção é uma preocupação subjacente às principais preocupações verificadas. Vale salientar que esse risco, isoladamente, é o terceiro fator mais importante apontado pelos executivos $(62,1 \%)$.

Manhire (2014) defende a natureza condicional de $p$, sob a perspectiva do contribuinte ${ }^{33}$. Sob tal perspectiva, $p$ é subjetivo e altera-se em função da decisão do contribuinte em relação à evasão, de modo que aqueles que escolhem omitir perceberiam um $p$ diferente daqueles que escolhem não omitir, por isso a sua natureza condicional. Isso muda a avaliação da "aposta" da evasão, pois submete o indivíduo a dois níveis de $p$, o que resulta na avaliação entre dois retornos distintos, obtidos sob riscos diferentes.

Essa diferenciação decorreria, em parte, da crença comum de que a omissão "acenderia uma luz vermelha" ou "subiria uma bandeira vermelha" nos sistemas da autoridade, indicando que há evasão. Sob essa heurística, declarações que apresentassem omissão possuiriam maior $p$, ou seja, os contribuintes reconheceriam, mais intuitivamente do que objetivamente, que $p$ não é fixo e que ele aumenta conforme o nível da evasão. Tal heurística criaria um comportamento interativo, em que poucos contribuintes omitiriam em relação ao que seria previsto pelos modelos clássicos, o que pode explicar o puzzle tax compliance (MANHIRE, 2014).

Cloyd (1995) e Cloyd et al.(1996) já haviam apresentado evidências empíricas nesse sentido. Eles verificaram que especialistas tributários e gerentes mantêm a heurística de que as DCT criam "alertas" para a autoridade ou uma posição tributária frágil no caso de uma auditoria. Percepção que, ante as constatações empíricas de Mills (1996, 1998) e Mills e Sansing (2000), seria justificada.

As proposições de Manhire (2014) partem da constatação teórica de que o $p$ enfrentado é condicionado pelas probabilidades de uma declaração conter uma omissão $(\phi)$ e de a autoridade realizar uma auditoria $(\alpha)$. Com isso, ter-se-ia $p_{1}$ e $p_{2}$ que representariam, respectivamente, a probabilidade quando há omissão e a probabilidade quando não há omissão, sob a perspectiva da autoridade.

\footnotetext{
${ }^{33}$ Essa linha de pensamento é definida por Manhire (2014) como Perspectiva-dependent Audit Probability Theory
} 


$$
p_{1}=\frac{\alpha \cap \phi}{\phi} \quad p_{2}=\frac{\alpha \cap(1-\phi)}{(1-\phi)}
$$

Considerando que $p$ é dado pela formulação tradicional (taxa de auditoria), que a proporção de declarações entregues que contém omissão é $\sigma$ e que a probabilidade de uma declaração com omissão ser detectada dada uma auditoria é $\Phi, p_{1}$ e $p_{2}$ podem ser escritos da seguinte maneira:

$$
p_{1}=p\left(\frac{\Phi}{\sigma}\right) \quad p_{2}=p\left(\frac{1-\Phi}{1-\sigma}\right)
$$

Sendo $\Phi \neq \sigma$, como tende a ser, tem-se que $p_{1} \neq p_{2} \neq p^{34}$, de modo que a probabilidade de uma declaração ser auditada dado que ela contém uma omissão é diferente daquela em que não há uma omissão (MANHIRE, 2014).

Muito embora esses ajustes ofereçam uma dimensão mais realista da percepção média dos indivíduos, tem-se que ainda não é possível diferenciar $p$ entre eles. A subjetividade condicional da forma proposta por Manhire (2014) está intimamente relacionada à ideia de que $p$ é endógeno e que varia conforme a evasão, o que não é totalmente contemplado pelos ajustes.

\subsection{Escolhas Contábeis e Incentivos Tributários}

Os primeiros estudos que investigaram o efeito de incentivos tributários sobre escolhas contábeis foram realizados nos Estados Unidos na década de 1970. Basicamente, o foco principal dessas pesquisas era avaliar a reação do mercado à divulgação da adoção do UEPS (Último que Entra Primeiro que Sai), visando testar hipóteses concorrentes, à época, relacionadas à eficiência de mercado. Sob uma dessas hipóteses, a adoção do UEPS estaria relacionada com o aumento do preço das ações, uma vez que, via de regra, esse critério reduz a tributação e, assim, aumenta os fluxos de caixa da firma (WATTS; ZIMMERMAN, 1986).

Naquele cenário, a escolha contábil de adotar ou não o UEPS era fortemente influenciada pelo incentivo tributário, pois a utilização desse critério para fins tributários, em razão de uma exigência legal, implicava, necessariamente, na sua adoção para fins de divulgação financeira, ou seja, a conformidade contábil-tributária (doravante, conformidade) passava a ser obrigatória. Watts e Zimmerman (1986), Jenkins e Pincus (1998), Fields, Lys e Vincente (2001) e Shackelfor e Shevlin (2001), documentam boa parte desses estudos, cujos

\footnotetext{
${ }^{34}$ Além disso, $p_{2} \neq(1-p)$
} 
resultados, de uma maneira geral, apontam que o incentivo tributário prevaleceu e direcionou as escolhas contábeis.

Conclusão semelhante é obtida com base nos resultados obtidos por Boynton, Dobbins e Plesko (1992), Scholes, Wilson e Wolfson (1992), Guenther (1994) e Choi e Lee (2013), os quais evidenciam que firmas gerenciaram seus resultados, no sentido de postergar o reconhecimento de lucros, visando a redução da tributação explícita, em resposta a alterações no sistema tributário que promoveram reduções de alíquotas.

Outro exemplo é Erickson, Heitzman e Zhang (2013), os quais verificaram que firmas anteciparam o reconhecimento contábil de perdas, visando apurar prejuízo fiscal e, assim, requerer o reembolso de tributos já pagos (tax loss carryback). Os resultados demonstraram que as firmas que enfrentavam restrições financeiras se mostraram mais agressivas na adoção dessa estratégia.

Por outro lado, os resultados obtidos por Johnson e Dhaliwal (1988) indicam que firmas abandonaram o UEPS, motivadas por incentivos de divulgação financeira associados a restrições de contratos de dívidas. Esses resultados sugerem que os benefícios dessa escolha teriam sido superiores ao ônus assumido com o aumento da tributação.

Phillips, Pincus e Rego (2003), por sua vez, verificaram que a despesa relacionada à tributação diferida (vinculada às diferenças temporárias do lucro) foi utilizada para fins de gerenciamento de resultado. As constatações dessa pesquisa apontam que, apesar da redução da tributação, esse gerenciamento visou aumentar o lucro contábil, com o intuito de evitar a divulgação de queda nos lucros ou de prejuízos. Explorando temática semelhante no cenário brasileiro, Paulo, Martins e Corrar (2007) constataram que a tributação diferida não aumenta o poder preditivos dos modelos de detecção de gerenciamento de resultado analisados.

Já as evidências apresentadas por Dhaliwal, Gleason e Mills (2004) indicam que firmas utilizaram a despesa da tributação sobre o lucro para aumentar seus resultados, quando outras escolhas pré-tributação se mostraram sem sucesso. Constatou-se que, para tanto, a despesa tributária foi utilizada como uma reserva cookie jar ${ }^{35}$. Essas evidências alinham-se à hipótese de gerenciamento de resultado visando atingir as previsões dos analistas. Gupta, Laux e Lynch (2015) encontraram evidências nessa direção em relação à manipulação de reservas

\footnotetext{
${ }^{35}$ Quando o lucro se mostrava abaixo das previsões dos analistas, as firmas diminuíam a tributação do $4^{\circ}$ trimestre, em relação ao $3^{\circ}$ trimestre. Do contrário, essa tributação era aumentada.
} 
tributárias $^{36}$, especificamente no período anterior à adoção da FASB Interpretation $n^{o} 48$, Accounting for Uncertainty in Income Taxes (FIN 48).

Os resultados obtidos por Badertscher et al. (2009) mostram que firmas que possuíam saldo de prejuízo fiscal e/ou eram auditadas por grandes firmas de auditorias (Big 4/5/6) teriam aumentado seus lucros por meio de gerenciamento de resultados em que foram utilizadas escolhas contábeis que também afetaram o lucro tributário. Segundo Badertscher et al. (2009), isso teria sido possível porque o prejuízo fiscal compensaria o aumento da tributação, enquanto a melhor qualidade da auditoria elevaria o risco de a estratégia ser descoberta, nos casos de um gerenciamento sem conformidade.

Os estudos acima representam um fragmento da literatura que ilustra as tensões entre os incentivos de divulgação financeira e os incentivos tributários geradas em torno das escolhas contábeis. Scholes et al. (2009) argumentam que nem sempre é possível estabelecer um tradeoff entre os benefícios tributários e os custos de divulgação financeira, raciocínio que é extensível à relação entre os benefícios de divulgação financeira e os custos tributários (maior tributação, maior risco de detecção etc.).

As escolhas contábeis e tributárias estão inseridas em uma complexa teia de incentivos econômicos, de modo que não podem ser definidas isoladamente. Nesse cenário, marcado pela assimetria informacional e em que os agentes buscam maximizar a sua riqueza, os incentivos tributários e de divulgação financeira seriam interdependentes na definição da escolha contábil, a qual sempre implicará em algum nível de custo em uma dessas duas dimensões (CLOYD ET AL., 1996; MILLS, 1998; SHACKELFOR; SHEVLIN, 2001; SCHOLES ET AL., 2009; BADERTSCHER ET AL., 2009).

Uma questão importante, nesse contexto, é se as estratégias tributárias são implementadas em conformidade com as regras contábeis, afetando diretamente a divulgação financeira, ou se são implementadas exclusivamente na esfera de apuração do tributo. $\mathrm{Na}$ primeira situação, o lucro é reduzido em detrimento da divulgação financeira, o que pode indicar que o incentivo tributário prevaleceu. Enquanto na segunda, o lucro contábil é preservado e a resposta a esse incentivo se dá extracontabilmente, via ajustes tributários. Aqui, a configuração ideal, em princípio, seria um lucro maior para fins de divulgação financeira e um lucro menor para fins tributários.

\footnotetext{
${ }^{36}$ Essas reservas registram as estimativas de pagamentos futuros de tributos relacionados a posições tributárias incertas, as quais são passíveis de questionamento pela autoridade. Tais posições são referenciadas pela FIN 48 como Unrecognized Tax Benefits (UTB).
} 
Em um mundo onde $p=0$, a conformidade, provavelmente, não seria uma alternativa interessante. Nesse cenário, a evasão tributária seria praticada sem impor custos de divulgação financeira adicionais, o que mitigaria os problemas relacionados ao trade-off entre tais custos e os benefícios tributários desejados. Além disso, a complementaridade, tal qual proposta por Desai e Dharmapala (2006a), também tenderia a não existir, pois as estratégias tributárias não necessitariam ser realizadas de forma obscura.

Por outro lado, a introdução de um $p>0$, bem como de algum nível de penalidade, modifica a definição do trade-off entre os benefícios tributários líquidos e os custos com as estratégias tributárias (tributários ou não), uma vez que tais benefícios passam a ser afetados pelos custos provenientes de uma eventual detecção (penalidades, exposição pública etc.). Desse modo, a adoção de estratégias tributárias em conformidade com as escolhas contábeis poderá se tornar uma opção possível, caso os custos de divulgação financeira sejam baixos e $p$ seja suficientemente elevado.

De acordo com Cloyd et al. (1996), muito embora haja uma associação positiva entre os custos de divulgação financeira e a conformidade, esta geraria dois benefícios tributários que poderiam compensar aqueles custos: (1) a redução de p; (2) o aumento das chances de manutenção de uma posição tributária agressiva, se questionada pela autoridade. Conforme verificado por Cloyd (1995) e Cloyd et al. (1996), essa seria uma percepção dominante entre os especialistas tributários.

Os resultados de Cloyd et al. (1996) indicam que as escolhas contábeis são influenciadas pela posição tributária assumida pela firma, o que seria explicado por aquela percepção. No entanto, eles verificaram que as firmas de capital aberto são menos propensas à conformidade do que as de capital fechado, o que seria justificado pelo fato de que elas seriam mais sensíveis aos custos de divulgação financeira. Conclusão que é compartilhada por Mills (1996, 1998), Mills e Sansing (2000) e Hanlon, Mills e Slemrod (2005)

Outrossim, Hoopes, Mescall e Pittman (2012) verificaram que essas firmas teriam assumido posições tributárias menos agressivas quando a atuação do IRS se mostrou mais rigorosa, indicando que elas também seriam mais sensíveis aos custos de detecção. Dado que as firmas de capital aberto são maiores e possuem maior visibilidade política e social, essa constatação alinha-se à fundamentação da hipótese dos custos políticos.

Entretanto, as evidências obtidas por Frank, Lynch e Rego (2009) e Wilson (2009) ${ }^{37}$ indicam que há uma relação positiva entre as agressividades para fins de divulgação financeira

\footnotetext{
${ }^{37}$ Frank, Lynch e Rego (2009) utilizam uma medida de agressividade tributária que é baseada exclusivamente nas $D C T$ permanentes, enquanto Wilson (2009) considera componentes permanentes e temporários das DCT.
} 
e para fins tributários, o que sinaliza a existência de menores níveis de conformidade. Segundo Frank, Lynch e Rego (2009), essa constatação sugere que os custos assumidos em tais práticas não seriam relevantes, ante os respectivos benefícios, a ponto de motivar o trade-off entre os incentivos tributários e de divulgação financeira.

Esses resultados, em princípio, contrariam o senso de que quanto menor a conformidade, maior será a probabilidade de detecção, o que é suportado pelas evidências apresentadas por Mills (1996, 1998) e Mills e Sansing (2000).

Além disso, tais conclusões são confrontadas pelos resultados obtidos por Lennox, Lisowsky e Pittman (2013), os quais não suportam a existência de uma associação positiva entre as agressividades financeira e tributária. As constatações obtidas nesse estudo indicam que a fraude contábil é negativamente relacionada à agressividade tributária. Lennox, Lisowsky e Pittman (2013) verificaram que a incidência de fraudes contábeis é maior entre as firmas tributariamente menos agressivas.

De acordo com Hoopes, Mescall e Pittman (2012), as estratégias de redução da tributação adotadas pelas firmas provavelmente refletem seu entendimento sobre 0 comportamento da atuação da autoridade. Otimizando suas estratégias de afastar o risco de detecção, as firmas podem reduzir os custos associados com multas e juros que podem incorrer no caso de a omissão ser detectada em uma auditoria. Adicionalmente, as firmas podem afastar a publicidade negativa e custos com litigância que podem surgir com uma auditoria. Por outro lado, conforme Desai e Dharmapala (2006a, 2009a), Desai, Dick e Zingales (2007) a redução daquele risco também pode contribuir com o aumento do oportunismo gerencial.

Hanlon, Hoopes e Shroff (2014) constataram que $p$ é negativamente associado às acumulações discricionárias. Tendo em vista que estas têm sido consideradas pela literatura como proxy para o oportunismo, notadamente no âmbito do gerenciamento de resultado (HEALY, 1985; JONES, 1991; DECHOW; SLOAN; SWEENEY, 1995; PAULO, 2007; DECHOW ET AL., 2012). A constatação de Hanlon, Hoopes e Shroff (2014) pode representar uma evidência direta da influência de $p$ sobre as escolhas contábeis. Trata-se de um resultado importante, dada a robustez demonstrada, assim como em razão da inexistência de estudos que tenham investigado especificamente essa influência.

No Brasil, a maioria dos estudos têm como foco o gerenciamento de resultado, no entanto, ainda estão em uma fase inicial e apresentam evidências conflitantes (FORMIGONI; ANTUNES; PAULO, 2009; PIQUEIRAS, 2010; FERREIRA ET AL., 2012; FORMIGONI ET AL., 2012; REZENDE; NAKAO, 2012). 
Por exemplo, Piqueiras (2010) verificou que o gerenciamento de resultado está relacionado a comportamentos anormais estimados com base em modelos de DCT. Já Rezende e Nakao (2012) constataram que existe uma relação negativa entre o lucro tributável e esse gerenciamento. Contrariamente, Ferreira et al. (2012) concluíram que há uma relação diretamente proporcional entre as $D C T$ e as acumulações discricionárias, cujas evidências sugerem que as firmas praticaram o gerenciamento de resultado na mesma direção do sinal observado para as $D C T$ correspondentes.

Contudo, alguns estudos têm explorado aspectos interessantes relacionados aos efeitos, mesmo que indiretos, dos incentivos tributários sobre as escolhas contábeis. Um deles é Cabello (2012), o qual verificou que as principais práticas tributárias passíveis de implementação por meio de escolhas contábeis, aceitas pela legislação tributária do IRPJ, utilizadas pelas firmas de capital aberto brasileiras analisadas foram: (i) depreciação acelerada; (ii) depreciação acelerada incentivada; (iii) juros sobre o capital próprio; (iv) reorganização societária; e (v) incentivos fiscais. Cabello (2012) constatou que as firmas que implementaram pelo menos uma dessas práticas, apresentaram menor alíquota efetiva para o IRPJ e a CSLL.

Já Mello e Salotti (2013) apresentaram evidências que indicam que a opção das firmas pelo $R T T^{38}$, para os anos de 2008 e 2009, foi estratégica, uma vez que foi direcionada pela redução da carga tributária. Os resultados indicaram que $65 \%$ do total das firmas tributadas pelo lucro real não optaram por aquele regime e sugerem que estas teriam pago menos IRPJ e CSLL nos anos de 2008 e 2009, comparativamente aos anos de 2005 a 2007.

Essa constatação é interessante pois levanta, no mínimo, duas hipóteses quanto à motivação daquela escolha: (i) as firmas não optaram pelo RTT a fim de mitigar os efeitos decorrentes da redução não discricionária do seu resultado, em função da adoção dos IFRS, por meio da consequente redução da tributação; ou (ii) as firmas não optaram pelo RTT no intuito de utilizar a maior discricionariedade permitida pelos IFRS como estratégia tributária legalmente aceita para reduzir a tributação, sem afetar o lucro contábil.

\footnotetext{
38 O RTT foi instituído em 2008, sua adoção passou a ser obrigatória a partir do ano de 2010 e ele foi extinto em 31/12/2014. O RTT visou assegurar a neutralidade tributária em relação à adoção dos IFRS. No entanto, para os anos de 2008 e 2009, sua adoção foi opcional. Se a firma optasse por tal regime, ela poderia apurar o IRPJ, a CSLL, o PIS/Pasep e a Cofins com base nos métodos e critérios contábeis vigentes em 31/12/2007. Se não, a apuração desses tributos seria realizada com base nos números contábeis reconhecidos e mensurados de acordo com os IFRS. Essa opção ofereceu a oportunidade para que as firmas pudessem adotar estratégias tributárias sem, necessariamente, assumir custos adicionais de divulgação financeira, uma vez que, em ambas as situações, a informação contábil estaria, em princípio, preservada, apesar da opção ter gerado um menor nível de conformidade (SANTOS, 2015).
} 
Silva et al. (2013) avaliaram se existia uma relação positiva entre a implantação do Sped Contábil e os níveis de receita bruta e lucro líquido declarados pelas firmas. A ideia subjacente desse estudo é o fato de que o Sped Contábil representaria mais um instrumento de monitoramento tributário, o que elevaria a percepção de risco de detecção das firmas, uma vez que a autoridade passa a dispor de um maior volume de informações para fins de análise no âmbito da seleção das auditorias.

Os resultados obtidos por Silva et al. (2013) indicam que há uma associação positiva e altamente significativa entre a adoção do Sped Contábil e a receita bruta, no entanto, os autores reconhecem que seria preciso avaliar a inclusão de variáveis de controle capazes de capturar o efeito das variações do ambiente econômico sobre as receitas. Quanto ao lucro líquido, foi constatada uma associação fracamente negativa (significativa a 10\%). Os autores argumentam que esse resultado se deveria ao fato de que o modelo utilizado seria muito frágil à presença de lucros extremos, bem como em relação à presença de $G R$.

A conclusão principal que surge diante das proposições teóricas e das evidências empíricas relacionadas à evasão tributária é o fato de que a definição e a extensão das estratégias tributárias a serem empreendidas são fortemente influenciadas pela probabilidade de detecção percebida pelos agentes. Desse modo, seja sob a perspectiva de que evasão tributária é uma transferência de riqueza do Estado para firma, seja em decorrência dos conflitos de agência comumente estudados ou então em razão da complementaridade, não é possível afastar a hipótese de que essa probabilidade é um importante determinante para as escolhas contábeis. E essa é a hipótese que será testada no presente estudo. 


\section{ESTRUTURA TEÓRICO-ANALÍTICA}

A estrutura aqui proposta busca formalizar matematicamente os aspectos teóricos discutidos na seção anterior, de modo a permitir a análise da interação entre as escolhas contábeis oportunistas e a evasão tributária, bem como os efeitos da probabilidade de detecção tributária sobre essa relação. Basicamente, ela representa a tese aqui defendida.

Trata-se de uma estrutura analítica bastante simplificada, restrita a um único período, a qual não oferece predições definidas sobre os fenômenos analisados, mas sim, um meio para interpretá-los. O modelo representa a função objetivo de um agente avesso ao risco, com função utilidade $(U)$ de von Neumman-Morgenstern, em que $U^{\prime}>0>U^{\prime \prime}$ e $U(0)=0$. O ponto central analisado é a decisão sobre o trade-off relativo à implementação de escolhas contábeis oportunistas e de estratégias tributárias evasivas. Para tanto, são derivadas as condições sob as quais as variações na probabilidade detecção afetam essa decisão e, com base nessa análise, são formuladas as hipóteses da pesquisa.

\subsection{Premissas e Definições}

Considere que o agente possui uma compensação contratual por desempenho que oferece, além de uma remuneração fixa $\phi$, um bônus $0<\omega<1$ sobre o lucro após a tributação $(L L)$. A firma é indiferente quanto à evasão tributária e não incentiva tal prática (pelo menos explicitamente). Nesse sentido, em linha com Crocker e Slemrod (2005), é assumido que o contrato de compensação prevê uma redução $0<\eta \leq 1$ sobre a remuneração do agente, vinculada à penalidade imposta pela autoridade $(\pi t)$, no caso de uma eventual auditoria ${ }^{39}$. Sendo assim, a remuneração total do agente $(\Upsilon)$, em que $\omega \leq \eta \pi$, é dada por:

$$
\Upsilon=\phi+\omega L L-\eta \pi t
$$

Os lucros efetivamente produzidos pela firma $(L)$ são exógenos, estritamente positivos e não observáveis pelo principal nem pela autoridade tributária. Dada a discricionariedade presente nos processos de reconhecimento e mensuração contábeis, é o agente quem define o lucro para fins de divulgação financeira [lucros antes $(L C)$ e após $(L L)$ a tributação], bem como determina o lucro tributável $(L T)$ que, juntamente com $L C$, é declarado para a autoridade.

\footnotetext{
${ }^{39}$ A remuneração do agente é tributada a uma alíquota $0<\tau<1$. Contudo, por simplificação, essa tributação é omitida na discussão e no modelo, uma vez que seus efeitos sobre a remuneração total do agente não serão analisados. Assume-se que as decisões do agente sobre a evasão da firma já incorporam tais efeitos.
} 
Considerando que a decisão de interesse envolve a evasão tributária, tem-se que $L C \in$ $[\underline{L C}, \overline{L C}]$ e $L T \in[\underline{L T}, \overline{L T}]$, tal que $L C \geq L^{+}>L T$ ou $L^{+}>L C \geq L T$, onde $L^{+}$é a parcela de $L C$ isenta de oportunismo, a qual será melhor definida adiante.

O Lucro Contábil $(L C)$ pode ser representado pelo somatório entre o fluxo de caixa líquido das operações (FCO) e as acumulações (accruals) totais (DECHOW; DICHEV, 2002), as quais podem ser segregadas em discricionárias $(A D)$, ou anormais, e não-discricionárias (AND), ou normais (HEALY, 1985; JONES, 1991; DECHOW; SLOAN; SWEENEY, 1995; PAULO, 2007). Indo um pouco mais além, tem-se ainda que, se discricionárias, as acumulações poderão ser oportunistas $(x)$ ou não $\left(A D_{N o p}\right)^{40}$. Assim, é possível elaborar a seguinte formulação:

$$
L C=F C O+A N D+\left(A D_{N O p}+x\right)
$$

Considerando que a parcela de $L C$ isenta de oportunismo $\left(L^{+}\right)$consiste na medida contábil mais aproximada de $L$, tem-se, portanto, que $L C=L^{+}+x^{41}$, onde $x \in[\underline{x}, \bar{x}]$

A firma é tributada a uma alíquota $0<\theta<1$, incidente sobre $L T$, o qual, por sua vez, corresponde a $L C$ ajustado pelas adições (ajustes positivos), exclusões e compensações (ajustes negativos) previstas na legislação tributária ${ }^{42}$. Tais ajustes podem ser temporários ou permanentes e é possível representa-los pelas DCT. Dada essa definição, tem-se que:

$$
\begin{gathered}
L L=L C-\theta L T \therefore \\
L L=L C-\theta(L C-D C T)
\end{gathered}
$$

\footnotetext{
${ }^{40}$ Se a escolha contábil consiste em uma decisão que visa para influenciar de modo específico a informação contábil (FILDES; LYS; VINCENT, 2001), tem-se que é discricionária por natureza, de tal modo que a sua definição é motivada por algum incentivo econômico, seja visando, por exemplo, aprimorar a qualidade da divulgação financeira $\left(A D_{N O P}\right)$ ou transferir riqueza, de forma oportunista, em detrimento da firma ou do principal $(x)$.

${ }^{41}$ Em um mercado perfeito, ou seja, em um mundo sem incentivos capazes de motivar ações oportunistas e de total simetria informacional, por exemplo, $L C=L^{+}$.

${ }^{42}$ De uma maneira geral, tem-se que as adições correspondem às receitas (despesas) que não integraram (integraram) o $L C$, mas que deverão (não deverão) ser consideradas em $L T$. Já as exclusões referem-se às receitas (despesas) que integraram (não integraram) $L C$ e que poderão ser desconsideradas (consideradas) para fins de $L T$. Os ajustes temporários são aqueles realizados em um período e revertidos em algum momento futuro. Por exemplo, para fins do IRPJ e da CSLL, se atendidas as exigências legais, os ganhos de valor justo poderão ser EXCLUÍDOS na apuração de $L T$ no período do seu reconhecimento, no entanto deverão ser ADICIONADOS no período em que ocorrer a realização (liquidação) do respectivo ativo (passivo). Tal reversão não acontece no caso dos ajustes permanentes. Por exemplo, de acordo com a legislação do IRPJ/CSLL, a despesa referente às multas por infrações tributárias deve ser ADICIONADA na apuração de $L T$, tendo em vista que tais multas não são dedutíveis. Neste caso, esse ajuste não será revertido, seu efeito seria permanente.
} 
Igualmente às $A D$, as $D C T$ podem ser segregadas em ajustes/diferenças não oportunistas $\left(D C T_{N o p}\right)$ e ajustes/diferenças oportunistas $(y)$. Aquelas representam as diferenças mecânicas, normais, inerentes às divergências naturais existentes entre as normas contábil e tributária, já estas, são intencionais e representam as estratégias de evasão tributária, podendo, inclusive, ser relacionadas a $x$ (DESAI; DHARMAPALA, 2006a; TANG, 2011). Desse modo, assumindo que $y \in(0, \bar{y}]$ e considerando (3), (4) e (5), obtém-se:

$$
\begin{gathered}
L L=L^{+}+x-\theta\left(L^{+}+x-D C T_{N O p}-y\right) \\
L L=L^{+}(1-\theta)+\theta D C T_{N O p}+x(1-\theta)+\theta y \therefore \\
Y=\phi+\omega\left[L^{+}(1-\theta)+\theta D C T_{N O p}\right] \\
\underbrace{}_{\begin{array}{c}
\text { Parcela Não } \\
\text { Oportunista }
\end{array}}+\underbrace{\omega[x(1-\theta)+\theta y]-\eta \pi t}_{\begin{array}{c}
\text { Parcela } \\
\text { Oportunista }
\end{array}}
\end{gathered}
$$

por conveniência: $L L_{N o p}=L^{+}(1-\theta)+\theta D C T_{N O p}$

Portanto, com base em (6), define-se a Premissa 1:

Premissa 1: o agente pode aumentar a sua remuneração por meio de escolhas contábeis oportunistas elou de estratégias tributárias evasivas.

O contrato de compensação aqui definido oferece incentivos que alinham os interesses do agente aos do principal, assim como aos das demais partes interessadas (stakeholders). Sendo assim, a redução da tributação por meio de $x<0$ (conformidade), também impõe custos de divulgação financeira (redução da compensação, diminuição do valor de mercado da firma, aumento de juros em contratos de dívida etc.).

A perda de utilidade do agente em razão desses custos é representada pela função $\kappa(x)$, a qual também incorpora os efeitos da qualidade da governança corporativa, de modo que quanto mais efetivos os instrumentos de governança, maior será a perda de utilidade em razão de $x$. $\kappa(x)$ é a função diferenciável que atende as seguintes condições: (i) $\kappa(0)=0$; (ii) $\kappa^{\prime}(0)=0$; (iii) $\kappa\left(x_{1}\right)>\kappa\left(x_{2}\right) \forall x_{1}<0<x_{2}$; (iv) $\kappa^{\prime}(x)>0$; e (v) $\kappa^{\prime \prime}(x)>0$.

Por outro lado, se o agente reduz a tributação por meio de $y$, apesar de reduzir ou, até mesmo, eliminar os custos de divulgação financeira, poderá criar um ambiente favorável ao oportunismo gerencial e, assim, transferir riqueza em detrimento das outras partes contratuais. Além disso, ao elevar o nível de $y$, poderá aumentar também a probabilidade de a firma ser auditada tributariamente $(p)$. 
A autoridade observa $L C$ e $L T$ e só pode conhecer $L^{+}$após deflagrar uma auditoria. A autoridade não é capaz de auditar todas as firmas, de modo que uma dada auditoria é deflagrada a uma probabilidade $0<p<1$, não conhecida pelo agente. Além disso, assume-se que as auditorias: (i) são efetivas; (ii) geram uma receita líquida positiva para a autoridade; e (iii) não estão sujeitas a restrições orçamentárias, dada a capacidade operacional da autoridade.

Para a firma, a auditoria resultará na cobrança do montante da tributação evadida $t=\theta(|x|+y) \forall x<0$, ou $t=\theta y \forall x \geq 0$, e da penalidade $\pi t$ (custo de detecção), onde $\pi>\theta$, o qual representa a multa imposta sobre o montante do tributo evadido. Para o agente, a auditoria implicará na redução da sua remuneração pelo fator $\pi t(\omega+\eta)^{43}$. Não são consideradas as sanções criminais ou custos relacionados à reputação do agente.

Dadas essas definições adicionais, estrutura-se a Premissa2:

Premissa 2: o agente pode reduzir a tributação por meio de escolhas contábeis em conformidade com a regra tributária $(x<0)$ elou de estratégias tributárias sem conformidade com as regras contábeis ( $y>0$ ), para tanto estabelece o trade-off entre os custos de divulgação financeira e os custos de detecção.

Assume-se que a autoridade é estrategista e que define suas auditorias com base nas informações prestadas pelas firmas, bem como nas informações obtidas por meio de outros canais informacionais (clientes, fornecedores, credores etc.). O agente não conhece essas regras de seleção, mas percebe que seu comportamento influencia esse processo.

A literatura tem demonstrado que as $D C T$ poderiam sinalizar a agressividade tributária e que elas seriam positivamente associadas ao risco de detecção ou que, pelo menos, as firmas perceberiam que isso seria possível (CLOYD; PRATT; STOCK, 1996; MILLS, 1996, 1998; MILLS; SANSING, 2000; ERICKSON; HANLON; MAYDEW, 2004; BADERTSCHER ET AL, 2009; WILSON, 2009). Outrossim, firmas maiores possuem maior visibilidade política e tendem a ser mais monitoradas pelo Estado, o que as tornaria politicamente mais sensíveis (WATTS; ZIMMERMAN, 1978, 1986; ZIMMERMAN, 1986).

\footnotetext{
${ }^{43}$ Considerando que $L L^{\text {aud }}$ e $Y^{\text {aud }}$ são o lucro pós tributação e a remuneração do agente, respectivamente, no período em que a auditoria for finalizada, tem-se que $\Upsilon^{\text {aud }}=\phi+\omega L L^{\text {aud }}-\eta \pi t$, onde $L L^{\text {aud }}=L L-\pi \theta(|x|+y)$. Fazendo a diferença entre $\gamma^{\text {aud }}$ e $Y($ eq. 1$)$, obtém-se

$$
\begin{gathered}
\{\phi+\omega[L L-\pi t]-\eta[\pi t]\}-\{\phi+\omega L L\} \\
-\omega \pi t-\eta \pi t \\
-\pi t(\omega+\eta)
\end{gathered}
$$
}


Nessa linha, é possível que a percepção de risco dos agentes seja condicionada ao nível de agressividade das suas estratégias e que ela seja superestimada no caso das firmas maiores (CLOYD; PRATT; STOCK,1996; MANHIRE, 2014). Sendo assim, eis a Premissa 3:

Premissa 3: o agente decide sobre o oportunismo gerencial e a evasão tributária com base em um p subjetivo, condicional e endógeno, função do nível de DCT e do tamanho da firma, em que $p(.) \in(0,1)$, sendo $\quad \bar{p}_{1}()>.\bar{p}_{2}($.$) , se D C T_{1}>D C T_{2}$; $\frac{\partial \bar{p}}{\partial D C T}, \frac{\partial \bar{p}}{\partial T a m}>0 ; e \frac{\partial^{2} \bar{p}}{\partial D C T^{2}}, \frac{\partial^{2} \bar{p}}{\partial \operatorname{Tam}^{2}} \geq 0$.

Com base nas definições e premissas acima apresentadas, assume-se que o agente escolherá, sob incerteza, o nível de $x$ e $y$ que maximize a função de utilidade esperada abaixo:

$$
\max _{\{x, y\}} U=[1-p(.)] U\left(Y^{N A}\right)+p(.) U\left(Y^{A}\right)-\kappa(x)
$$

onde:

$Y^{N A}=$ Remuneração sem auditoria tributária, que é dada por:

$$
Y^{N A}=\left\{\phi+\omega\left[L L_{N O p}+x(1-\theta)+\theta y\right]\right\} ;
$$

$Y^{A}==$ Remuneração após uma auditoria tributária, que é dada por:

$$
Y^{A}=\left\{\phi+\omega\left[L L_{N O p}+x(1-\theta)\right]-\eta \pi t\right\}
$$

em que $U\left(Y^{N A}\right)>U\left(Y^{A}\right), \frac{\partial U}{\partial x}, \frac{\partial U}{\partial y}>0$ e $\frac{\partial^{2} U}{\partial x^{2}}, \frac{\partial^{2} U}{\partial y^{2}}<0$

\subsection{Análise e Formulação das Hipóteses da Pesquisa}

A análise aqui apresentada examina, com base na estática comparativa ${ }^{44}$ do modelo proposto, os efeitos das mudanças em y e $p\left(\right.$.) sobre a escolha ótima de $x\left(x^{*}\right)$. Secundariamente, também é avaliado o quão $y^{*}$ é afetado em função das variações em $x$ e $p($.).

A equação (7) foi apresentada na sua especificação mais geral, em que estão presentes todas as variáveis do modelo. Assim, considerando que a investigação é restrita às decisões

\footnotetext{
${ }^{44}$ A estática comparativa consiste na comparação entre dois estados de equilíbrio "estáticos", em função da alteração de algum parâmetro do modelo, mantendo os demais fixos (VARIAN, 2012)
} 
sobre os níveis de $x$ e $y$ que resultam em $L C \geq L^{+}>L T$ ou $L^{+}>L C \geq L T$, a análise foi segregada nos seguintes cenários:
a) Decisão 1: $L C=L^{+}>\operatorname{LT}(x=0$ e $y>0)$;
b) Decisão 3: $L^{+}>L C=L T(x<0$ e $y=0)$;
c) Decisão 2: $L C>L^{+}>L T(x>0$ e $y>0)$; e
d) Decisão 4: $L^{+}>L C>\operatorname{LT}($ x $<0$ e $y>0)$.

\subsubsection{Decisão 1: $L C=L^{+}>L T(x=0$ e $y>0)$}

A decisão 1 representa, unicamente, a estratégia de evasão tributária. Não há custos de divulgação financeira, consequentemente, $\kappa(x)=0$. A renda do agente varia conforme a evasão seja detectada ou não. $p($.) muda conforme o nível de $y$ escolhido.

Essa decisão pode ilustrar o cenário em que a firma, por exemplo, possui mecanismos de governança corporativa eficazes, seja pelo alinhamento dos interesses do agente aos do principal, seja pela efetividade do controle interno e transparência, de modo que os custos de divulgação financeira seriam elevados, o que tornaria o oportunismo gerencial economicamente proibitivo.

Sendo assim, o recurso adicional para exercer tal oportunismo é a evasão tributária. Portanto, o agente decidirá, sob incerteza, sobre $y^{*}$, a fim de maximizar a sua utilidade esperada que é dada pela função abaixo:

$$
\max _{\{y\}} U=[1-p(.)] U\left[\phi+\omega\left(L L_{N O p}+\theta y\right)\right]+p(.) U\left(\phi+\omega L L_{N O p}-\eta \pi t\right)
$$

Eis as condições de primeira e segunda ordens para que tal maximização ocorra:

$$
\begin{aligned}
\frac{\partial U}{\partial y}=\theta\left\{[1-p(.)] \omega U_{y}\left(Y_{1}^{N A}\right)-p(.) \eta \pi U_{y}\left(Y_{1}^{A}\right)\right\}-p_{y}(.)\left[U\left(Y_{1}^{N A}\right)-U\left(Y_{1}^{A}\right)\right]=0 \\
U_{y y}=\frac{\partial^{2} U}{\partial y^{2}}=\theta^{2}\left\{[1-p(.)] \omega^{2} U_{y y}\left(Y_{1}^{N A}\right)+p(.) \eta^{2} \pi^{2} U_{y y}\left(Y_{1}^{A}\right)\right\}- \\
2 p_{y}(.) \theta\left[\omega U_{y}\left(Y_{1}^{N A}\right)+\eta \pi U_{y}\left(Y_{1}^{A}\right)\right]-\quad p_{y y}(.)\left[U\left(Y_{1}^{N A}\right)-U\left(Y_{1}^{A}\right)\right]<0
\end{aligned}
$$


Proposição 1: aumentos em y elevarão a probabilidade de detecção, de modo que * $^{*}$ reduzirá com aumentos em y e será menor do que se definido sob uma probabilidade de detecção fixa.

Prova: Obtém-se diretamente de (9) e (10).

No ponto em que $y=0$, tem-se que $U\left(Y^{N A}\right)=U\left(Y^{A}\right)$, portanto, a condição de entrada para evasão é $\frac{1-p(.)}{p(.)}>\frac{\eta \pi}{\omega}$, que é o payoff exigido pelo agente para a primeira unidade monetária evadida $(y=1):[1-p().] \omega \theta-p(.) \eta \pi \theta>0$.

A partir da segunda unidade monetária evadida, no ponto em que $y>0$, o efeito do payoff na utilidade do agente passa a considerar $U_{y}\left(Y^{N A}\right)$ e $U_{y}\left(Y^{A}\right)$. Como $p($.) varia em função de $y$, o efeito dessa variação sobre $U\left(Y^{N A}\right)$ e $U\left(Y^{A}\right)$, que é capturado pelo terceiro termo de (9), passa a também ser incorporado, de modo que a evasão ocorrerá se $\left\{[1-p().] \theta \omega U_{y}\left(Y_{1}^{N A}\right)-\right.$ $\left.p_{y}() U.\left(Y_{1}^{N A}\right)\right\}-\left\{p(.) \theta \eta \pi U_{y}\left(Y_{1}^{A}\right)+p_{y}() U.\left(Y_{1}^{A}\right)\right\}>0$

As variações em $p($.$) afetam as preferências do agente, portanto, para cada nível de y$ haverá um conjunto de preferências específico, consequentemente, uma curva de utilidade com inclinação também específica.

Essa dinâmica resulta do efeito gerado pelo termo $p_{y}().\left[U\left(Y_{1}^{N A}\right)-U\left(Y_{1}^{A}\right)\right]$, expresso em (9). Como $U\left(Y^{N A}\right)>U\left(Y^{A}\right)$, esse efeito será sempre negativo, o que nada mais é do que a redução da utilidade esperada total em razão do aumento de $p($.) provocado pelo aumento em $y$.

Além disso, tem-se que a taxa de "desaceleração" da utilidade esperada do agente aumenta em $-2 p_{y}(.) \theta\left[\omega U_{y}\left(Y_{1}^{N A}\right)+\eta \pi U_{y}\left(Y_{1}^{A}\right)\right]-p_{y y}().\left[U\left(Y_{1}^{N A}\right)-U\left(Y_{1}^{A}\right)\right]$, de modo que a cada $y$, a função utilidade do agente fica mais côncava.

Sendo assim, tem-se que o nível de $y^{*}$ torna-se mais baixo, se comparado ao cenário em que $p($.$) é fixo, portanto, um p($.$) endógeno a y$ restringe ainda mais a evasão tributária, pois, aumentos nessa variável elevam o risco de detecção. Para uma melhor compreensão, a Figura 1 apresenta graficamente esse cenário.

A reta $q$, que representa o conjunto orçamentário da evasão, possui inclinação $-\frac{\eta \pi}{\omega} 45$. O agente evadirá se, no ponto em que $y=0$, a inclinação da sua curva de indiferença, que é dada

$45 \frac{y_{2}-y_{1}}{x_{2}-x_{1}}=\frac{\left\{\phi+\omega\left[L^{+}(1-\theta)+\theta D C T N O p\right]-\eta \pi \theta y\right\}-\left\{\phi+\omega\left[L^{+}(1-\theta)+\theta D C T N O p\right]\right\}}{\left\{\phi+\omega\left[L^{+}(1-\theta)+\theta D C T N O p+\theta y\right\}-\left\{\phi+\omega\left[L^{+}(1-\theta)+\theta D C T N O p\right]\right\}\right.}$ 
por $-\frac{[1-p(.)]}{p(.)}$, for maior do que a do conjunto orçamentário. As curvas $B$ representam as preferências do agente considerando um $p\left(\right.$.) fixo em relação a $y$. O ponto $y^{* *}$ é a escolha ótima para y nessas condições. Já as curvas $A_{1}, A_{2}$ e $A_{3}$, representam as curvas de indiferença do agente quando $p($.) é endógeno a $y$.

Figura 1: Escolha ótima de $y^{*}$ - $p$ fixo versus $p$ endógeno a $y$

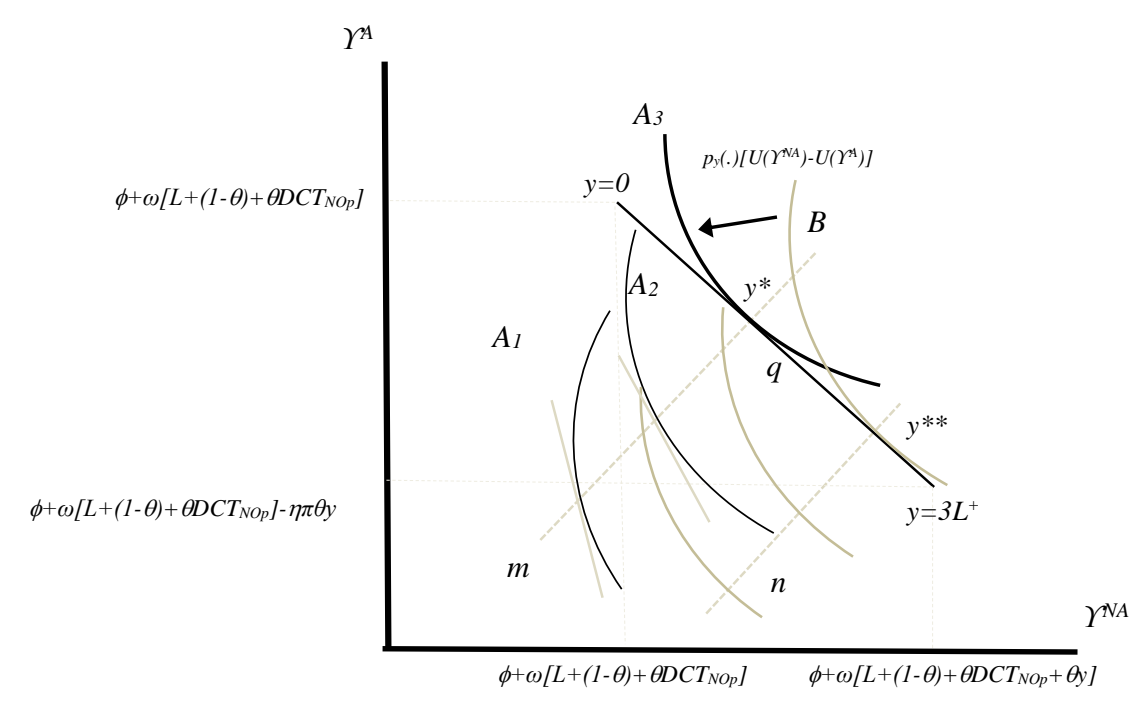

Fonte: elaboração própria.

Nos pontos colineares a $y^{* *}$ ao longo da reta $n$, a inclinação das curvas $B$ não muda, isso porque $p($.) não varia, consequentemente, não há mudança de preferências do agente. No entanto, ao se considerar um $p($.) endógeno a $y$, tem-se que cada alteração no nível dessa variável afeta tais preferências, o que é traduzido graficamente pela mudança (no caso, a diminuição) da inclinação das curvas $A_{1}, A_{2}$ e $A_{3}$, nos pontos colineares a $y^{*}$ ao longo da reta $m$. Tem-se, portanto, que $y^{*}<y^{* *}$, redução que é provocada pelo termo $p_{y}().\left[U\left(\Upsilon_{1}^{N A}\right)-U\left(\Upsilon_{1}^{A}\right)\right]$.

\subsubsection{Decisão 2: $L^{+}>L C=L T(x<0$ e $y=0)$}

Aqui, o agente reduz a tributação sem arcar com aumentos no custo de detecção em função de aumentos em $p($.), o que não significa ausência de risco. Por outro lado, ele tem sua remuneração reduzida e arca com níveis mais elevados de $\kappa(x)$ à medida que $x<0$. Nesta decisão, a função objetivo do agente é dada por: 


$$
\max _{\{x\}} U=[1-p(.)] U\left\{\phi+\omega\left[L L_{N o p}-x(1-\theta)\right]\right\}+p(.) U\left[\phi+\omega\left(L L_{N O p}-x\right)-\eta \pi t\right]-\kappa(x)
$$

As condições de primeira e segunda ordens são:

$$
\begin{gathered}
\frac{\partial U}{\partial x}=-[1-p(.)] \omega(1-\theta) U_{x}\left(\Upsilon_{2}^{N A}\right)-p(\omega+\eta \pi \theta)(.) U_{x}\left(\Upsilon_{2}^{A}\right)-\kappa_{x}(x)=0 \\
U_{x x}=\frac{\partial^{2} U}{\partial x^{2}}=[1-p(.)][\omega(1-\theta)]^{2} U_{x x}\left(\Upsilon_{2}^{N A}\right)+ \\
p(.)(\omega+\eta \pi \theta)^{2} U_{x x}\left(\Upsilon_{2}^{A}\right)-\kappa_{x x}(x)<0
\end{gathered}
$$

Proposição 2a: o agente não implementará a evasão tributária por meio de estratégias em que $x<0$ e $y=0$.

Prova: Obtém-se diretamente de (12).

Como $\theta<1$, para cada $\$ 1$ evadido, o agente reduz a sua remuneração em $\omega(1-\theta)$, situação que é agravada no caso de uma detecção, haja vista a penalidade $\eta \pi \theta$. Além disso, os custos de divulgação financeira tendem a se tornar mais representativos à medida que $x$ aumenta ("mais negativo"), de modo que reduzem ainda mais a utilidade esperada do agente.

Aumentos em $x$ reduzem tanto $U\left(Y^{\mathrm{NA}}\right)$ quanto $U\left(Y^{A}\right)$, pois geram utilidades marginais negativas para ambos. O payoff exigido para ganhos com $x<0$ é: $[1-p().] \omega(\theta-1)-$ $\left\{p().(\omega+\eta \pi \theta)+\kappa_{x}(x)\right\}>0$, condição que seria satisfeita se $\omega>\frac{p(.) \eta \pi \theta+\kappa_{x}(x)}{\theta[1-p(.)]-1}$, o que representa uma situação muito específica e pouco realista, uma vez que, para ser satisfeita, requer, necessariamente, $\theta>1$, em níveis extorsivos, e a ausência de custos de divulgação financeira e de detecção.

Sendo assim, nessa "loteria" somente haveria perdas (maiores ou menores) e o ponto máximo da função seria aquele em que $x=0$, ou seja, a melhor aposta seria não apostar, uma vez que, para o agente, a tributação seria menos onerosa do que evasão. Desse modo, os incentivos tributários, por si só, não seriam suficientes para motivar a evasão tributária por meio de estratégias desse tipo. 
Contudo, escolhas que envolvem $x<0$ podem gerar benefícios outros que não os tributários, um exemplo é a estratégia taking a bath, por meio da qual o agente pode maximizar sua recompensa futura esperada com a antecipação de perdas e/ou postergação de lucros (HEALY, 1985). Além disso, aquelas escolhas também podem reduzir os custos políticos da firma, como é postulado pela hipótese do tamanho (WATTS; ZIMMERMAN, 1986), ou então, garantir ou obter medidas protecionistas governamentais, tal qual verificado por Jones (1991). Na verdade, nesse cenário, esses incentivos dominariam os tributários, de modo que a redução da tributação seria um benefício adicional.

Considerando esse aspecto, é assumido que os benefícios decorrentes de baixos níveis de $L L$, obtidos oportunisticamente por meio de $x<0$, podem ser representados pela função diferenciável $\beta(x)$, em que $\beta(x)>0$ e $\beta_{x}(x), \beta_{x x}(x)>0 \forall x<0$. Sendo assim, é possível reescrever (9) da seguinte maneira:

$$
\max _{\{x\}} U=[1-p(.)] U\left(\Upsilon_{2}^{N A}\right)+p(.) U\left(\Upsilon_{2}^{A}\right)-\kappa(x)+\beta(x)
$$

Portanto, as condições de primeira e segunda ordem passam a ser dadas por:

$$
\begin{gathered}
\frac{\partial U}{\partial x}=-[1-p(.)] \omega(1-\theta) U_{x}\left(\Upsilon_{2}^{N A}\right)-p(.)(\omega+\eta \pi \theta) U_{x}\left(\Upsilon_{2}^{A}\right)-\kappa_{x}(x)+\beta_{x}(x)=0 \\
U_{x x}=\frac{\partial^{2} U}{\partial x^{2}}=[1-p(.)][\omega(1-\theta)]^{2} U_{x x}\left(\Upsilon_{2}^{N A}\right)+p(.)(\omega+\eta \pi \theta)^{2} U_{x x}\left(\Upsilon_{2}^{A}\right)- \\
\kappa_{x x}(x)+\beta_{x x}(x)<0
\end{gathered}
$$

Proposição 2b: o agente realizará, oportunisticamente, escolhas contábeis em que $x<0$, independentemente dos incentivos tributários.

Prova: Diretamente de (15).

Sob a nova configuração da função objetivo, o payoff passa a ser $\left[\beta_{x}(x)-\kappa_{x}(x)\right]-$ $\{[1-p().] \omega(1-\theta)+p().[\omega+\eta \pi \theta]\}>0$, de modo que, para um que o agente escolha $x<0$, seria necessário que:

$$
\beta_{x}(x)-\kappa_{x}(x)>[1-p(.)] \omega(1-\theta)+p(.)[\omega+\eta \pi \theta]
$$


Isso demonstra que, quanto maior a variação em $\beta(x)$ provocada por $x<0$, ou seja, quanto maior $\beta_{x}(x)$, mais rentável a escolha poderá se tornar para o agente. Assim, mesmo com utilidade marginais negativas para $U\left(Y^{N A}\right)$ e $U\left(Y^{A}\right)$ e aumentos em $\kappa_{x}(x)$, a utilidade gerada por $\beta(x)$ seria suficiente para aumentar a utilidade esperada total, de modo que seria possível que, à medida que $x$ se tornasse cada vez "mais negativo", a condição (17) pudesse ser satisfeita e, assim, ser obtido um $x^{*}<0$.

Um ponto de interesse é que os benefícios gerados por $x<0$ também podem ser usufruídos pela firma, Jones (1991) é um exemplo disso. Sendo assim, teoricamente, poderia ser interessante para o principal incentivar o agente a implementar escolhas em que $x<0$ e que, para tanto, o arranjo contratual de compensação fosse modificado, a fim de ajustar os parâmetros da remuneração variável nesse sentido, o que, necessariamente, afetaria a função objetivo do agente.

Proposição 2c: aumentos em p(.) restringem $x<0$.

Prova: Diretamente de (15).

Outro aspecto de interesse a ser tratado é a resposta de $x$ às variações em $p($.). A teoria tem demonstrado que mudanças nessa probabilidade restringem a evasão. Portanto, na decisão sob análise, espera-se que aumentos em $p($.) reduzam os níveis de $x$. Para avaliar essa proposição, (15) foi diferenciada em relação a $\rho=p($.$) :$

$$
\frac{\partial x}{\partial \rho}=\frac{1}{U_{x x}}\left[-\omega(1-\theta) U_{x}\left(\Upsilon_{2}^{N A}\right)+(\omega+\eta \pi \theta) U_{x}\left(\Upsilon_{2}^{A}\right)\right]
$$

Uma vez que $U_{x x}<0$, verifica-se que a derivada é negativa, portanto, tem-se que aumentos em $p($.) reduzem $x$, ou seja, restringem a evasão tributária, o que sustenta a proposição acima. Esse resultado se mantém para qualquer nível de $x<0$, uma vez que o termo entre colchetes é invariavelmente positivo, pois, $(\omega+\eta \pi \theta) U_{x}\left(\Upsilon_{2}^{A}\right)>\omega(\theta-1) U_{x}\left(\Upsilon_{2}^{N A}\right)$.

No caso sob análise, como a escolha de $x<0$ não seria direcionada pela evasão tributária, tem-se que a redução no nível de $x$ efetivar-se-ia caso o impacto do aumento de $p($.) no custo de detecção fosse significativo a ponto de inviabilizar o payoff do agente, considerando o nível de $\beta(x)$, na condição dada por (17). 


\subsubsection{Decisão 3: $L C>L^{+}>L T(x>0$ e $y>0)$}

Nesta decisão, o agente atua oportunisticamente para fins de divulgação financeira, ao tempo que pratica a evasão tributária. De um lado, evita-se custos de divulgação financeira (ou assume-se níveis menores), à medida que se reduz a tributação. Por outro lado, arca-se com um maior risco de detecção, em razão dos maiores níveis de $D C T$, muito embora os custos de detecção sejam definidos exclusivamente em função de $y$. Sob essa configuração, o modelo assume a seguinte formulação:

$$
\begin{array}{r}
\max _{\{x, y\}} U=[1-p(.)] U\left\{\phi+\omega\left[L L_{N O p}+x(1-\theta)+\theta y\right]\right\}+ \\
p(.) U\left\{\phi+\omega\left[L L_{N O p}+x(1-\theta)\right]-\eta \pi t\right\}-\kappa(x)
\end{array}
$$

O agente irá maximizar essa função pela combinação ótima entre $x$ e $y$. A condição de primeira ordem em relação a $x$ é:

$$
\frac{\partial U}{\partial x}=\omega(1-\theta)\left\{[1-p(.)] U_{x}\left(Y_{3}^{N A}\right)+p(.) U_{x}\left(Y_{3}^{A}\right)\right\}-\kappa_{x}(x)=0
$$

Já a condição de segunda ordem é dada por:

$$
U_{x x}=\frac{\partial^{2} U}{\partial x^{2}}=[\omega(1-\theta)]^{2}\left\{[1-p(.)] U_{x x}\left(Y_{3}^{N A}\right)+p(.) U_{x x}\left(Y_{3}^{A}\right)\right\}-\kappa_{x x}(x)<0
$$

As condições de primeira e segunda ordens em relação a y são semelhantes àquelas apresentadas em (9) e (10). Porém, aqui deverão ser considerados $Y_{3}^{N A}$ e $Y_{3}^{A}$.

Para maximizar (19), é necessário que $x *$ e $y *$ atendam:

$$
\begin{gathered}
H\left(x^{*}, y^{*}\right)=\left[\frac{\partial^{2} U}{\partial x^{2}}\left(x^{*}, y^{*}\right) \frac{\partial^{2} U}{\partial y^{2}}\left(x^{*}, y^{*}\right)\right]-\left[\frac{\partial^{2} U}{\partial x \partial y}\left(x^{*}, y^{*}\right) \frac{\partial^{2} U}{\partial y \partial x}\left(x^{*}, y^{*}\right)\right]>0 \\
\frac{\partial^{2} U}{\partial x^{2}}\left(x^{*}, y^{*}\right)<0 \quad \frac{\partial^{2} U}{\partial y^{2}}\left(x^{*}, y^{*}\right)<0
\end{gathered}
$$

em que $H\left(x^{*}, y^{*}\right)$ é o determinante da matriz hessiana. 
Proposição 3a: para $x, y>0$, x e y são complementares: aumentos (reduções) em y levam a aumentos (reduções) em x e vice-versa.

Prova: Diferenciando (20) com relação a y e (9) em relação a $x$.

Com base em (20), é possível perceber que o incremento marginal na remuneração do agente, dada a variação em $x$, é de $\omega(1-\theta)-\kappa_{x}(x)$, isso sem considerar qualquer estratégia de evasão tributária. As escolhas exclusivamente em relação a $x$ são indiferentes à detecção tributária, uma vez que aumentos nessa variável elevam igualmente $Y^{\mathrm{NA}}$ e $Y^{\mathrm{A}}$. Em um cenário em que $y=0$ ou invariante, $x$ seria elevado até o ponto em que $\kappa_{x}(x)$ se tornasse proibitivo. Por exemplo, a elevação do nível de remuneração do agente, bem como da tributação da firma, sem o efetivo fluxo de caixa associado a $x$, poderia acionar os mecanismos de governança da firma ou de proteção das demais partes contratuais.

Diante dos incentivos de divulgação financeira e dada a ideia de complementaridade proposta por Desai e Dharmapala (2006a), a evasão tributária pode representar um mecanismo adicional de oportunismo gerencial. Para avaliar o efeito de $y$ sobre $x$, (20) foi diferenciada em relação a $y$, de modo que:

$$
\begin{aligned}
\frac{\partial x}{\partial y}=- & \frac{1}{U_{x x}} \omega(1-\theta)\left\{[1-p(.)] \omega \theta U_{x y}\left(Y_{3}^{N A}\right)-p(.) \eta \pi \theta U_{x y}\left(Y_{3}^{A}\right)\right\}+ \\
& \frac{1}{U_{x x}} p_{y}(.) \omega(1-\theta)\left[U_{x}\left(Y_{3}^{N A}\right)-U_{x}\left(Y_{3}^{A}\right)\right]
\end{aligned}
$$

O segundo termo de (23) é positivo e pode ser visto como uma compensação de parte da redução da diminuição da utilidade marginal total de $x$. Isso ocorre porque parte do efeito da elevação de $p($.) sobre a utilidade esperada total, decorrente de aumentos em $y$, é atenuada, uma vez que $x>0$ e, neste caso, a detecção somente gera custos em função de $y$. Essa compensação ofereceria uma margem para a escolha de um nível maior de $x$. Contudo, o efeito do primeiro termo, consequentemente, o efeito total daqueles aumentos, depende das variações do grau de aversão ao risco absoluto do agente (decrescente, constante ou crescente) ${ }^{46}$. Para examinar esse aspecto, (23) foi reescrita com a introdução do valor de $p($.$) , obtido com base em (20). Assim:$

\footnotetext{
${ }^{46} \mathrm{O}$ grau de aversão ao risco do indivíduo pode variar conforme a sua riqueza aumenta. No presente caso, a avaliação refere-se a um risco fixo, ou seja, um montante de $x$ ou $y$, portanto, o interesse é quanto à aversão ao risco absoluto. Diz-se que o indivíduo apresenta aversão ao risco absoluto decrescente (crescente) se a sua aversão ao risco diminui (aumenta) com o aumento da renda. Se o grau de aversão se mantém constante, o indivíduo exibe aversão ao risco absoluto constante. Quanto maior a aversão ao risco absoluto, maior será a medida de ArrowPratt.
} 


$$
\begin{aligned}
\frac{\partial x}{\partial y}= & \frac{1}{U_{x x}}[1-p(.)] \omega(1-\theta) U_{x}\left(Y_{3}^{N A}\right)\left[\omega \theta R_{A}\left(Y_{3}^{N A}\right)-\eta \pi \theta R_{A}\left(Y_{3}^{A}\right)(\delta-1)\right]+ \\
& \frac{1}{U_{x x}} p_{y}(.) \omega(1-\theta)\left[U_{x}\left(Y_{3}^{N A}\right)-U_{x}\left(Y_{3}^{A}\right)\right]
\end{aligned}
$$

em que $R_{A}$ é a medida de aversão ao risco absoluto de Arrow-Pratt, que é dada por $-U^{\prime \prime}(\Upsilon) / U^{\prime}(\Upsilon)$; e $\delta=\frac{\kappa_{x}(x)}{[1-p(.)] \omega(1-\theta) U_{x}\left(Y_{3}^{N A}\right)}$.

Com base em (24), é possível observar que a magnitude da relação entre a variação dos custos de divulgação financeira decorrentes de aumentos em $x$ e a utilidade marginal esperada dessa variável, ou seja, $\delta$, pode ser considerado o principal direcionador dos efeitos de $y$ sobre $x$.

Aumentos em $x$ tendem a elevar $\kappa_{x}(x)$, o que é potencializado pela qualidade da governança corporativa. Por outro lado, tais aumentos tendem a reduzir a utilidade marginal de $Y^{N A}$, de modo que é muito provável que $\delta>1$. Sendo assim, sob uma aversão ao risco absoluto não crescente, $R_{A}\left(Y^{A}\right) \geq R_{A}\left(Y^{N A}\right)$, que é uma hipótese mais realista, aumentos em y poderão resultar em aumentos em $x$, na hipótese de níveis mais elevados de $\kappa_{x}(x)$, desde que o aumento no risco de detecção não seja suficientemente elevado, dado que aumentos em $y$ implicam em aumentos nesse risco, conforme demonstrado na seção 3.2.1. Sob essa condição, os benefícios advindos de $y$ seriam suficientes para mitigar a elevação de $\kappa_{x}(x)$.

Essa conclusão alinha-se à Desai e Dharmapala (2006a), inclusive no que se refere aos efeitos da governança corporativa, na medida em que quanto melhor for a qualidade desta, maior será o benefício da evasão para agente, desde que os custos dessa prática não sejam elevados. Em (24), isso é verificado por meio de $\delta$.

Outro aspecto de interesse na avaliação da complementaridade é o efeito de $x$ sobre $y$. Para examina-lo, foi realizada a diferenciação de (9) em relação a $x$ que, considerando o coeficiente de aversão ao risco absoluto de Arrow-Pratt e substituindo $p($.) com base em (9), é dada por:

$$
\begin{aligned}
\frac{\partial y}{\partial x}= & \frac{1}{U_{y y}}[1-p(.)] \omega^{2} \theta(1-\theta) U_{y}\left(Y_{3}^{N A}\right)\left[R_{A}\left(Y_{3}^{N A}\right)-R_{A}\left(Y_{3}^{A}\right)(1-\varphi)\right]+ \\
& \frac{1}{U_{y y}} p_{y}(.) \omega(1-\theta)\left[U_{x}\left(Y_{3}^{N A}\right)-U_{x}\left(Y_{3}^{A}\right)\right]
\end{aligned}
$$


em que $\varphi=\frac{p_{y}(.)\left[U\left(Y_{3}^{N A}\right)-U\left(Y_{3}^{A}\right)\right]}{[1-p(.)] \omega \theta U_{y}\left(Y_{3}^{N A}\right)}$

Aqui, é possível verificar que $x$ afetará positivamente $y$ caso o agente apresente aversão ao risco absoluto não crescente e a variação na probabilidade de detecção decorrente do $y$ adicional sobre a utilidade total for menor que a utilidade marginal de $U\left(Y^{\mathrm{NA}}\right)$ em relação a essa variável $(y)$, isto é, que $0<\varphi<1$. Tem-se que aumentos em $x>0$ diminuem a probabilidade de detecção, pois reduzem as $D C T$, além disso, tais aumentos não geram custo adicional de detecção, desse modo, os aumentos em y podem ser efetivados arcando-se com um menor nível de risco. Outrossim, também há o efeito positivo advindo da compensação de parte da redução da diminuição da utilidade marginal de $x$ (segundo termo da equação). Essas constatações também indicam a complementaridade entre $x$ e $y$, reforçando o que se observou em (24).

Nas duas situações analisadas, com base em (24) e (25), também se verificam que diminuições em $y$ reduzem $x$ e vice-versa, o que se alinha à ideia da inter-relação entre governança corporativa e governança tributária discutida por Desai e Dharmapala (2008) e Desai, Dick e Zingales (2007). De um lado, a restrição da evasão reduz os "espaços" para o oportunismo, de outro, reduções no oportunismo tornam a evasão menos rentável.

Dado que $y>0$, reduções em $x$ implicam em maiores $D C T$, acarretando, assim, maior risco de detecção, de modo que restringirão $y$. Já reduções nesta variável tendem a restringir $x$, na hipótese em que haja níveis elevados de custos de divulgação financeira. Além disso, considerando que o agente possui aversão ao risco não crescente, reduções na renda aumentam o grau dessa aversão, de maneira que seria possível que, em um determinado nível de $x$ e/ou $y$, $R_{A}\left(\Upsilon^{A}\right)<R_{A}\left(Y^{\mathrm{NA}}\right)$.

Partindo da ideia de governança tributária, guarda especial interesse o efeito das variações de $p($.$) , independentes de y$, sobre $x$, uma vez que em (24) e (25) foi possível avaliar aquelas variações associadas a $y$.

Proposição 3b: para $x, y>0$, x e y são complementares: aumentos em $p($.$) reduzem x$.

Prova: Diretamente de (9) e (24) e diferenciando (20) com relação a $\rho=p($.$) .$

$$
\frac{\partial x}{\partial \rho}=\frac{1}{U_{x x}} \omega(1-\theta)\left[U_{x}\left(Y_{3}^{N A}\right)-U_{x}\left(Y_{3}^{A}\right)\right]
$$


Tem-se que $x>0$, por si só, não gera custos de detecção, pois, como não haverá evasão, o agente será indiferente à atuação estatal. Como já verificado em (24), dado que $y>0$, as variações em $p($.$) , decorrentes dos aumentos em y$, repercutem um efeito positivo sobre $x$, o que igualmente é evidenciado por (26). Contudo, conforme pode ser deduzido de (9) (seção 2.3.1), aumentos em $p($.) restringem $y$, redução que, por sua vez, também tendem a restringir $x$, naqueles casos em que os custos de divulgação financeira são elevados, como visto com base em (24). Sendo assim, aumentos em $p($.) restringem $x>0$, indiretamente, em função das reduções provocadas em $y$. Esses pontos também reforçam a ideia de complementaridade, neste caso, decorrente da governança tributária.

Proposição 3c: para $x, y>0$, x e y são complementares: aumentos em $\omega$ reduzirão $y$, desde que os custos de detecção sejam suficientemente elevados.

Prova: Diferenciando (9) com relação a $\omega$.

$$
\begin{aligned}
\frac{\partial y}{\partial \omega}= & \frac{1}{U_{y y}}[1-p(.)] \theta U_{y}\left(Y_{3}^{N A}\right)\left[\omega M R_{A}\left(Y_{3}^{N A}\right)-N R_{A}\left(Y_{3}^{A}\right)(\omega-\psi)\right]-\frac{1}{U_{y y}}[1-p(.)] \theta U_{y}\left(Y_{3}^{N A}\right)+ \\
& \frac{1}{U_{y y}} p_{y}(.)\left[M U_{\omega}\left(Y_{3}^{N A}\right)-N U_{\omega}\left(Y_{3}^{A}\right)\right]
\end{aligned}
$$

em que $M=L L_{N O p}+x(1-\theta)+\theta y, N=L L_{N O p}+x(1-\theta)$ e $\psi=\frac{p_{y}(.)\left[U\left(\Upsilon_{3}^{N A}\right)-U\left(\Upsilon_{3}^{A}\right)\right]}{[1-p(.)] \theta U_{y}\left(\Upsilon_{3}^{N A}\right)}$

À luz da teoria de agência, um maior o alinhamento entre os interesses do agente e do principal leva à redução do oportunismo gerencial. Nesse sentido, sob a hipótese da complementaridade, tais reduções também levariam à redução da evasão tributária, desde que os custos de detecção fossem suficientemente elevados. E isso é possível verificar em (27).

Mecanicamente, aumentos em $\omega$ provocam aumentos em $y$, proporcionalmente a $U\left(Y^{N A}\right)$, o que é dado pelo segundo termo de (27). Observe-se, porém, que maiores níveis de $p($.) reduzem os efeitos sobre $y$. Outrossim, obtém-se aumentos em y em razão da compensação de parte da redução da utilidade marginal $\omega$, que é observada no terceiro termo de (27), isso porque os aumentos em $\omega$ não geram custo de detecção adicional. Neste caso, os aumentos serão diretamente proporcionais às variações de $p($.). 
Entretanto, o efeito líquido dos aumentos de $\omega$ sobre $y$ dependerá do grau de aversão ao risco absoluto exibido pelo agente, como pode ser visto no primeiro termo de (27). Se essa aversão for não crescente, o agente tenderá a reduzir $y$, sempre que $\psi>1$, isto é, a variação na probabilidade de detecção decorrente do $y$ adicional sobre a utilidade total for superior à utilidade marginal de $U\left(Y_{3}^{N A}\right)$. Sendo assim, a redução de $y$ é esperada, tendo em vista que $0<$ $\omega<1$ e pelo fato que a utilidade marginal decresce à medida que $y$ aumenta, enquanto aquela variação no risco de deteç̧ão é crescente.

\subsubsection{Decisão 4: $L^{+}>L C>L T(x<0$ e $y>0)$}

Ao implementar estratégias em que $x<0$ e $y>0$, o agente consegue reduzir a tributação, arcando com um menor risco de detecção, bem como mitigar os efeitos negativos sobre a sua remuneração. Nesta decisão, a função objetivo do agente é dada por:

$$
\begin{aligned}
\max _{\{x, y\}} U= & {[1-p(.)] U\left\{\phi+\omega\left[L L_{N O p}-x(1-\theta)+\theta y\right]\right\}+p(.) U\left[\phi+\omega\left(L L_{N O p}-x\right)-\eta \pi t\right]-} \\
& \kappa(x)+\beta(x)
\end{aligned}
$$

As condições de primeira e segunda ordem de (28), em relação a $x$, são semelhantes a (15) e (16), respectivamente. Já em relação a y, são equivalentes a (9) e (10). As condições para um máximo de (28) em $\left(x^{*}, y^{*}\right)$ são similares àquelas apresentadas em (22).

Como visto na Decisão 2, o agente não implementará $x<0$ em resposta a incentivos tributários. Essa escolha será realizada se, e somente se, $\beta_{x}(x)$ satisfizer (17). Trata-se de uma decisão direcionada, exclusivamente, pelo oportunismo gerencial. Sendo assim, a questão principal na decisão em que $x<0$ e $y>0$ é a interação com $\beta(x)$, precisamente, a relação entre a magnitude desses benefícios e aqueles gerados por $y>0$.

Proposição 4a: para $x<0$ e $y>0$, aumentos em y reduzirão $x$ enquanto $\beta_{x}(x)$ satisfizer (17).

Prova: Diferenciando (15) com relação a y.

$$
\begin{gathered}
\frac{\partial x}{\partial y}=-\frac{1}{U_{x x}}[1-p(.)] \omega(1-\theta) U_{x}\left(Y_{4}^{N A}\right)\left[\omega \theta R_{A}\left(Y_{4}^{N A}\right)-\eta \pi \theta R_{A}\left(Y_{4}^{A}\right)(\mu-1)\right]+ \\
\frac{1}{U_{x x}} p_{y}(.)\left[-\omega(1-\theta) U_{x}\left(Y_{4}^{N A}\right)+(\omega+\eta \pi \theta) U_{x}\left(Y_{4}^{A}\right)\right]
\end{gathered}
$$


onde $\mu=\frac{\beta_{x}(x)-\kappa_{x}(x)}{[1-p(.)] \omega(1-\theta) U_{x}\left(Y_{4}^{N A}\right)}$

Apesar de aumentos em $y$ elevarem $U\left(Y^{\mathrm{NA}}\right)$, atenuando os efeitos de $x(x<0)$, eles reduzem $U\left(Y^{A}\right)$, adicionalmente a $x$. Como este segundo efeito tende a ser maior, se $\beta(x)$ atender (17), de modo que $x<0$, tem-se que $y>0$ tenderá a anular, total ou parcialmente, aqueles benefícios.

Tendo em vista que (17) é condição necessária e suficiente para $x<0$, tem-se que, sob uma aversão ao risco absoluto não crescente, aumentos em $y$ tenderão a reduzir os níveis de $x$ para compensar a redução da utilidade gerada em $U\left(Y^{A}\right)$, até o ponto em que $\beta(x)$ não compense qualquer $x<0$. É somente a partir desse ponto que aumentos em $x<0$ poderão ser verificados em função dos aumentos em $y$, pois, estes compensarão a redução de $L L$, efeito que será condicionado à magnitude dos aumentos no risco de detecção.

Analisando o primeiro termo de (29), tem-se que, se atendida a condição (17), de modo que $\mu>1$, aumentos em $y$ implicarão em reduções em $x$, isto é, a evasão tenderá a se manter constante, porém o oportunismo gerencial diminuirá. Isso sugere que, em níveis elevados de $\beta_{x}(x)$, ou seja, quando $\beta(x)$ apresentar uma maior resposta aos aumentos em $x<0$, não haverá complementaridade entre $x$ e $y$, pois os benefícios serão mutuamente excludentes, tendo em vista o maior custo de detecção esperado assumido com $y>0$.

Já o segundo termo nada mais é do que o efeito negativo da variação da probabilidade de detecção sobre $x$, decorrente de aumentos em $y$, que é semelhante ao demonstrado em (18).

Desse modo, tem-se comprovada a primeira parte da proposição: aumentos em y implicarão na redução de $x$, desde que $\mu>1$.

A segunda parte da proposição refere-se à hipótese em que $\mu \leq 1$. Nessa situação, temse que não foi atendida a condição (17), portanto, $x<0$, por si só, não poderia, racionalmente, ser implementado em resposta a incentivos tributários, portanto $x^{*}=0$. Nesse ponto, não há diferença entre as utilidades marginais e os graus de aversão ao risco absoluto do agente. Assim, é possível que:

$$
\begin{aligned}
\frac{\partial x}{\partial y}=- & \frac{1}{U_{x x}}[1-p(.)] \omega(1-\theta) U_{x}\left(Y_{4}\right)\left\{R_{A}\left(\Upsilon_{4}\right)[\omega \theta-\eta \pi \theta(\mu-1)]\right\}+ \\
& \frac{1}{U_{x x}} p_{y}(.) U_{x}\left(\Upsilon_{4}\right)[\theta(\omega+\eta \pi)]
\end{aligned}
$$


O primeiro termo da derivada será positivo, de modo que aumentos em y no ponto em que $x=0$ permitirão escolhas em que $x<0$, desde que os aumentos na probabilidade de detecção não sejam elevados. Já o segundo termo será negativo e será potencializado por $p_{y}($.), o que reforça o efeito daquela probabilidade sobre os resultados.

Proposição 4b: para $x<0$ e y>0, aumentos em $x$ reduzirão $y$, desde que a variação na probabilidade de detecção seja suficientemente elevada.

Prova: Diferenciando (9) com relação a $x$.

$$
\begin{aligned}
\frac{\partial y}{\partial x}=- & \frac{1}{U_{y y}}[1-p(.)] \omega \theta U_{y}\left(Y_{4}^{N A}\right)\left[\omega(1-\theta) R_{A}\left(Y_{4}^{N A}\right)-(\omega+\eta \pi \theta) R_{A}\left(Y_{4}^{A}\right)(1-\varphi)\right]+ \\
& \frac{1}{U_{y y}} p_{y}(.)\left[-\omega(1-\theta) U_{x}\left(Y_{4}^{N A}\right)+(\omega+\eta \pi \theta) U_{x}\left(Y_{4}^{A}\right)\right]
\end{aligned}
$$

em que, semelhante a (25), $\varphi=\frac{p_{y}(.)\left[U\left(\Upsilon_{3}^{N A}\right)-U\left(\Upsilon_{3}^{A}\right)\right]}{[1-p(.)] \omega \theta U_{y}\left(Y_{3}^{N A}\right)}$

Se a variação da probabilidade for maior do que a utilidade marginal em razão de aumentos em $y, \varphi>1$, aumentos em $x$ reduzirão $y$, o que é certo haja vista que o segundo termo de (31) é negativo. $x<0$ reduz a renda e, sob uma aversão ao risco absoluto não crescente, o agente tornar-se-ia mais avesso a assumir o risco adicional decorrente de $y>0$, inclusive pelo aumento da probabilidade de detecção. Além disso, $x<0$ poderá proporcionar o mesmo nível de tributação que seria obtido com $y>0$, acarretando menor risco de detecção, no entanto, maiores níveis de $x<0$ elevarão os custos de divulgação financeira e poderão produzir utilidades marginais negativas.

Como nesse cenário a escolha de $x<0$ é realizada onde $y>0$, tem-se que (17) deixa de ser condição necessária, muito embora continue sendo suficiente. Assim, a definição dos níveis de $x<0$ e $y>0$ será o resultado do trade-off entre $\beta(x), \kappa(x)$ e os benefícios tributários líquidos.

\subsubsection{Representação Gráfica da Tese}

As conclusões derivadas das interações e associações aqui demonstradas e analisadas constituem a tese objeto deste trabalho, cuja síntese é representada graficamente na Figura 2. 
Figura 2: Decisão do agente - Oportunismo Gerencial x Evasão Tributária

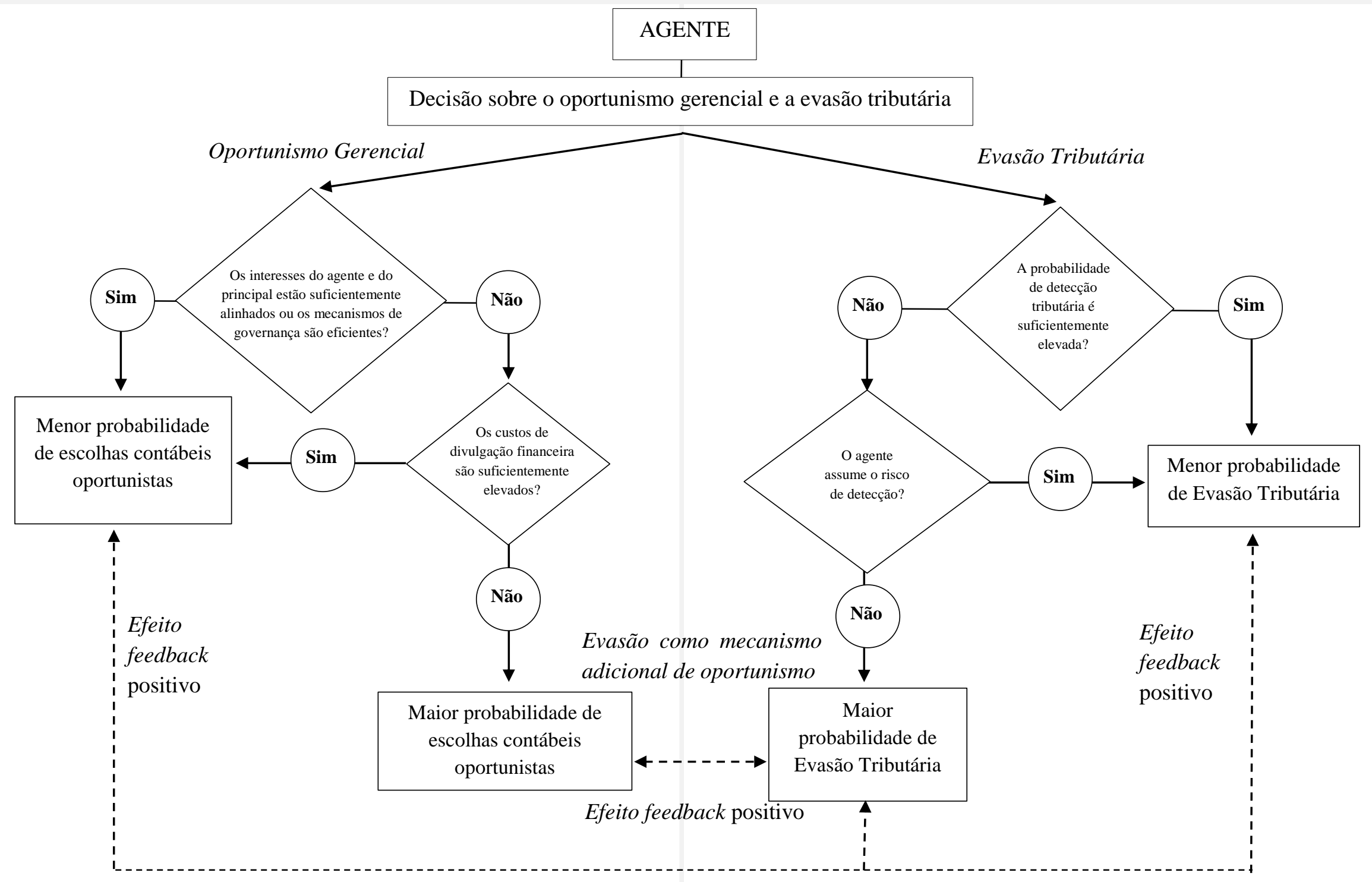

Fonte: elaboração própria. 


\subsubsection{Hipóteses da Pesquisa}

Com base na estrutura teórico-analítica aqui proposta, bem como nas evidências apresentadas pela literatura, foram formuladas 6 hipóteses de pesquisa, as quais são enunciadas no Quadro 1.

Quadro 1 - Hipóteses da Pesquisa

\begin{tabular}{|l|c|}
\hline \multicolumn{1}{|c|}{ Hipóteses } & $\begin{array}{c}\text { Proposições } \\
\text { relacionadas }\end{array}$ \\
\hline $\begin{array}{l}\text { H1: há uma associação negativa e estatisticamente significativa entre a probabilidade } \\
\text { de detecção tributária e as escolhas contábeis oportunistas realizadas pelas firmas } \\
\text { brasileiras de capital aberto. }\end{array}$ & 2c e 3b \\
\hline $\begin{array}{l}\text { H2: a associação negativa entre a probabilidade de detecção tributária e as escolhas } \\
\text { contábeis oportunistas realizadas pelas firmas brasileiras de capital aberto é mais } \\
\text { forte quando os mecanismos de governança corporativa são mais fracos. }\end{array}$ & 2a e 2b \\
\hline $\begin{array}{l}\text { H3: há uma associação negativa e estatisticamente significativa entre a probabilidade } \\
\text { de detecção tributária e os ajustes tributários anormais realizados pelas firmas } \\
\text { brasileiras de capital aberto. }\end{array}$ & 1 \\
\hline $\begin{array}{l}\text { H4: há uma associação negativa e estatisticamente significativa entre a probabilidade } \\
\text { de detecção tributária e os ajustes tributários totais realizados pelas firmas brasileiras } \\
\text { de capital aberto. }\end{array}$ & 1 \\
\hline $\begin{array}{l}\text { H5: a associação negativa entre a probabilidade de detecção tributária e os ajustes } \\
\text { tributários anormais realizados pelas firmas brasileiras de capital aberto é mais forte } \\
\text { quando os mecanismos de governança corporativa são mais fracos. }\end{array}$ & 3a e 4a \\
\hline $\begin{array}{l}\text { H6: há uma inter-relação significativa entre as escolhas contábeis oportunistas e os } \\
\text { ajustes tributários anormais realizados pelas firmas brasileiras de capital aberto. }\end{array}$ & 3a, 4a e 4b \\
\hline
\end{tabular}

Fonte: elaboração própria.

Vale salientar que as proposições relacionadas às hipóteses $H 2$ e $H 5$ não tratam, diretamente, da inter-relação entre a probabilidade de detecção tributária e a qualidade dos mecanismos de governança corporativa. Contudo, como os efeitos da governança corporativa são incorporados por $\kappa(x)$, tem-se que, com base nas condições de primeira ordem dadas pelas equações (12), (15) e (20), é possível observar que quanto maior for $\kappa_{x}(x)$ (a taxa de variação de $\kappa(x)$ ), menor será o payoff da decisão, de modo que, em níveis suficientemente elevados, decorrentes da qualidade da governança corporativa, é possível que $\kappa(x)$ seja capaz de mitigar os efeitos de $p($.$) , pois poderia inviabilizar a decisão da evasão em razão da restrição imposta$ ao oportunismo gerencial. Relação esta que encontra suporte teórico na discussão apresentada na seção 2.1.4. 


\section{PROCEDIMENTOS METODOLÓGICOS}

\subsection{Base de Dados}

Os dados contábeis, financeiros ${ }^{47}$ e cadastrais das firmas objeto de análise na etapa empírica da presente pesquisa, foram obtidos no banco de dados Economática $@$, cuja coleta foi realizada em 26/11/2015. Os demais dados utilizados, bem como as respectivas fontes, são apresentados no Quadro 2.

Quadro 2 - Bases de Dados

\begin{tabular}{|c|c|}
\hline Dados & Fontes \\
\hline $\begin{array}{l}\text { Identificação da firma de auditoria. } \\
\text { Big 4: (1) Deloitte Touche Tohmatsu; (2) } \\
\text { Ernest Young; (3) KPMG International } \\
\text { Cooperative; e (4) PricewaterhouseCoopers; }\end{array}$ & \multirow{3}{*}{$\begin{array}{l}\text { Formulários de referência apresentados pelas firmas à } \\
\text { Comissão de Valores Mobiliários (CVM). } \\
\text { Disponível em: http://www.cvm.gov.br. }\end{array}$} \\
\hline $\begin{array}{l}\text { Tipo de remuneração paga aos } \\
\text { administradores (fixa, variável ou baseada } \\
\text { em ações/opções) }\end{array}$ & \\
\hline Proporção de investidores institucionais & \\
\hline $\begin{array}{l}\text { Identificação do segmento de governança } \\
\text { corporativa (Novo Mercado, Nível } 1 \text { e Nível } \\
2 \text { da BM\&FBOVESPA) }\end{array}$ & $\begin{array}{l}\text { Listagem BM\&FBOVESPA. } \\
\text { Disponível em: http://www.bmfbovespa.com.br }\end{array}$ \\
\hline Cobertura de analistas & Thomson Reuters $\subset$ \\
\hline Quantidade de firmas auditadas pela RFB & $\begin{array}{l}\text { Relatórios "Resultados da Fiscalização". } \\
\text { Disponível em: } \\
\text { http://idg.receita.fazenda.gov.br/dados/receitadata } \\
\text { Lei de Acesso à Informação (Lei no } 12.527 / 2011 \text { ). } \\
\text { Pedidos registrados no Sistema Eletrônico do Serviço de } \\
\text { Informação ao Cidadão (e-SIC) sob os protocolos n }{ }^{\text {os }} \\
\text { 16853006496201519 e } 16853006497201563 \text {, ambos de } \\
\text { 19/9/2015. }\end{array}$ \\
\hline $\begin{array}{l}\text { Quantidade de firmas sujeitas ao } \\
\text { acompanhamento } \\
\text { diferenciado da RFB }\end{array}$ & $\begin{array}{l}\text { Lei de acesso à informação }\left(\text { Lei }^{\circ}{ }^{12.527 / 2011)} \text {. }\right. \\
\text { Pedido registrados no e-SIC registrado sob o protocolo } \\
n^{\circ} 16853007461201505 \text {, de } 28 / 10 / 2015\end{array}$ \\
\hline $\begin{array}{l}\text { Dados fiscais (receita bruta, quantidade de } \\
\text { firmas etc.) }\end{array}$ & $\begin{array}{l}\text { Relatório "Dados Setoriais - 2009/2013" } \\
\text { Disponível em: } \\
\text { http://idg.receita.fazenda.gov.br/dados/receitadata }\end{array}$ \\
\hline
\end{tabular}

Fonte: dados da pesquisa

\footnotetext{
${ }^{47}$ Os dados contábeis e financeiros foram ajustados pela inflação, tomando como referência o Índice Nacional de Preços ao Consumidor Amplo (IPCA) em 31/12/2013.
} 


\subsection{Período da Análise e Periodicidade dos Dados}

Em função da limitação dos dados relativos à atuação da físcalização da $R F B$, o período investigado compreendeu os anos de 2010 a 2013.

Dado o porte das firmas analisadas, assumiu-se que todas são tributadas com base no Lucro Real. Sendo assim, a fim de evitar distorções, devido a existência de várias formas de apuração no âmbito dessa sistemática de tributação (trimestral, anual com estimativa mensal e anual com estimativa mensal/ balanço ou balancete de suspensão) e a impossibilidade de identifica-las corretamente para todas as firmas, a periodicidade dos dados foi anual.

O período analisado coincidiu com a adoção obrigatória do RTT, instituído pela Lei $n^{\circ}$ $11.941 / 2009$.

\subsection{Amostra}

A amostra da pesquisa foi composta pelas firmas de capital aberto do mercado acionário brasileiro, que se encontravam ativas em 26/11/2015, de acordo com a indicação do banco de dados Economática (․ Os dados considerados se referiram às demonstrações contábeis individuais, na medida em que a tributação do IRPJ e da CSLL é efetivada nessa dimensão.

Depois dos ajustes, a amostra contou com 234 firmas e 846 firmas-ano, conforme evidenciado na Tabela 1.

Tabela 1 - Definição da Amostra de Pesquisa

\begin{tabular}{lcc}
\hline & Firmas & Firmas-ano \\
\hline Amostra inicial & $\mathbf{5 5 8}$ & $\mathbf{2 . 2 3 2}$ \\
Exclusão de setores & $(\mathbf{1 0 6})$ & $\mathbf{( 4 2 4 )}$ \\
$\quad$ Agro e Pesca * & $(7)$ & $(28)$ \\
Finanças e Seguros* & $(99)$ & $(396)$ \\
Dados ausentes/insuficientes & & \\
Amostra Final & $\mathbf{( 2 1 8 )}$ & $\mathbf{( 9 6 2 )}$ \\
\cline { 2 - 3 } & $\mathbf{2 3 4}$ & $\mathbf{8 4 6}$ \\
\hline
\end{tabular}

* Descrição dada pelo Economática, categoria "Setor Economática". Fonte: dados da pesquisa.

Tendo em vista que a legislação tributária confere tratamento específico para determinadas atividades ou segmentos econômicos, como é o caso, por exemplo, da atividade imobiliária, atividade rural e das instituições financeiras, as firmas foram segregadas em 6 (seis) 
setores econômicos, definidos com base na classificação proposta pelo Economática () e naquela adotada nos relatórios da fiscalização da RFB, conforme evidenciado na Tabela 2.

Essa foi a principal razão para exclusão das firmas do setor "agro e pesca", pois, como a legislação tributária dá tratamento específico em relação ao prejuízo fiscal ${ }^{48}$ e à depreciação dos itens do imobilizado ${ }^{49}$ e somente 7 firmas estavam disponíveis, não seria possível segregalas em um setor específico, tampouco não seria prudente incluí-las em um dos demais setores.

Já as firmas do setor "Financeiro e Seguros" foram excluídas em função das suas caraterísticas muito peculiares (estrutura de capital, ambiente de negócio, regulação etc.), além disso, segundo Peasnell, Pope e Young (2000), os processos de acumulações dessas firmas seriam diferentes daqueles das firmas de outros setores, os quais não seriam adequadamente capturados pelos modelos tradicionais, dentre eles o Jones-Modificado, modelo que é utilizado na presente pesquisa.

Tabela 2 - Quantidade de Firmas por Setor

\begin{tabular}{llccccc}
\hline \multirow{2}{*}{ Setores } & \multicolumn{5}{c}{ Firmas } \\
& & \multicolumn{5}{c}{ (Firmas Diferenciadas) } \\
\cline { 3 - 6 } & & 2010 & 2011 & 2012 & 2013 & Total \\
\hline \multirow{2}{*}{1} & \multirow{2}{*}{ Indústria (Setor 1) } & $(59)$ & $(60)$ & $(62)$ & $(61)$ & $(242)$ \\
& & 14 & 14 & 14 & 14 & 56 \\
2 & Comércio (Setor 2) & $(11)$ & $(12)$ & $(12)$ & $(12)$ & $(47)$ \\
\multirow{2}{*}{3} & Construção Civil (Setor 3) & 17 & 17 & 18 & 17 & 69 \\
& Serviços de Comunicação, Água e & $(3)$ & $(3)$ & $(5)$ & $(4)$ & $(15)$ \\
4 & Energia (Setor 4) & $(29)$ & $(32)$ & $(31)$ & $(30)$ & $(122)$ \\
\multirow{2}{*}{5} & Transporte e serviços relacionados & 34 & 35 & 37 & 36 & 142 \\
& (Setor 5) & $(25)$ & $(22)$ & $(27)$ & $(30)$ & $(104)$ \\
\multirow{2}{*}{6} & Outros (Setor 6) & 33 & 36 & 34 & 35 & 138 \\
& & $(15)$ & $(16)$ & $(13)$ & $(14)$ & $(58)$ \\
\hline \multirow{2}{*}{ Totais } & 205 & 213 & 214 & 214 & $\mathbf{8 4 6}$ \\
& & $(142)$ & $(145)$ & $(150)$ & $(151)$ & $(\mathbf{5 8 8})$ \\
\hline
\end{tabular}

Fonte: dados da pesquisa

Dentre as ações de monitoramento realizadas pela $R F B$, está o acompanhamento econômico-tributário diferenciado, cujo foco é os contribuintes, pessoa jurídica e pessoa física, de maior capacidade contributiva. Esse acompanhamento consiste no monitoramento da

\footnotetext{
${ }^{48}$ Art. 512. O prejuízo apurado pela pessoa jurídica que explorar atividade rural poderá ser compensado com o resultado positivo obtido em períodos de apuração posteriores, não se lhe aplicando o limite previsto no caput do art. 510 (BRASIL, 1999).

49 Art. 314. Os bens do ativo permanente imobilizado, exceto a terra nua, adquiridos por pessoa jurídica que explore a atividade rural (art. 58), para uso nessa atividade, poderão ser depreciados integralmente no próprio ano de aquisição (BRASIL, 1999)
} 
arrecadação, na análise do econômico-tributário de setores e de grupos econômicos e no tratamento ações, pendências e passivo tributário de tais contribuintes (RFB, 2012, 2015a)

Essas ações de acompanhamento são gerenciadas por uma coordenação específica Coordenação Especial de Maiores Contribuintes (Comac) ${ }^{50}$ - e executadas por equipes de Auditores Fiscais, distribuídas pelas dez Regiões Fiscais da RFB, por Delegacias Especiais e, subsidiariamente pelas demais Delegacias da Receita Federal em todo Brasil. (RFB, 2013).

A $R F B$, anualmente, divulga os parâmetros para a seleção das pessoas jurídicas que serão submetidas ao acompanhamento diferenciado, os quais consideram os montantes anuais: (i) da receita bruta; (ii) da massa salarial; (iii) dos débitos tributários declarados; e (iv) dos débitos previdenciários declarados ${ }^{51}$.

Dada a limitação dos dados que compõem a amostra, a avaliação dos parâmetros ficou restrita à receita bruta, no entanto, pela indisponibilidade desse número, para tal avaliação foi considerada a receita líquida, o que impõe o risco de subestimar o número total de firmas diferenciadas. Desse modo, a definição de tais firmas seguiu os critérios apresentados no Quadro 3.

Quadro 3- Critério de Classificação das Firmas Diferenciadas

\begin{tabular}{|c|c|c|}
\hline Ano & Parâmetro & Norma Relacionada \\
\hline 2010 & Receita Líquida de 2008 > R\$ 80 milhões. & Portaria RFB n 2.923/2009 \\
\hline 2011 & Receita Líquida de 2009 > R\$ 90 milhões. & Portaria RFB no $2.357 / 2010$ \\
\hline 2012 & Receita Bruta de $2010>\mathrm{R} \$ 100$ milhões & Portaria RFB n⿳3 3.778/2011 \\
\hline 2013 & Receita Bruta de $2011>$ R $\$ 120$ milhões & Portaria RFB $\mathrm{n}^{\circ} 2.563 / 2012$ \\
\hline
\end{tabular}

Fonte: www.receita.fazenda.gov.br

\footnotetext{
50 Art. 116. À Coordenação Especial de Maiores Contribuintes - Comac compete gerenciar as atividades relacionadas com acompanhamento econômico-tributário dos maiores contribuintes, bem assim administrar e supervisionar as atividades pertinentes à Divisão de Acompanhamento dos Maiores Contribuintes - Dimac e à Divisão de Estudos e Projetos - Diesp. (BRASIL, 2012)

${ }^{51}$ Massa salarial informada e os débitos previdenciários declarados nas guias de recolhimento do fundo de garantia do tempo de serviço e informações à previdência social (GFIP). Os débitos tributários declarados nas declarações de débitos e créditos tributários federais (DCTF).
} 


\subsection{Modelos Econométricos}

A ideia central que foi explorada é que $p$ exerce influência sobre as escolhas contábeis, cujo suporte teórico advém da hipótese da complementaridade entre oportunismo gerencial e a evasão tributária.

Os modelos econométricos utilizados para testar as hipóteses formuladas com base na estrutura teórico-analítica proposta no Capítulo 3, foram construídos a fim de permitir a avaliação da relação entre ESC e DCTA de forma recíproca, mas não necessariamente simultânea. Eis as equações:

$$
\begin{aligned}
\text { ESC }_{i t}=\beta_{0}+ & \beta_{1} \text { Prob }_{i t}+\beta_{2} \text { Prob_Dif }_{i t} \\
+ & \beta_{3} \text { DCT }_{i t} \\
+ & \lambda_{1} \text { Inv }_{-} \text {Inst }_{i t}+\lambda_{2} \text { Gov }_{i t}+\lambda_{3} \text { Rem }_{i t}+\lambda_{4} \text { Analist }_{i t}+\lambda_{5} \text { Endv }_{i t} \\
& +\delta_{1} \text { Ativo }_{i t}+\delta_{2} d 2011+\delta_{3} d 2012+\delta_{4} d 2013+\varepsilon_{i t}
\end{aligned}
$$

$$
\begin{aligned}
& \text { DCTA }_{i t}=\beta_{0}+\beta_{1} \text { Prob }_{i t}+\beta_{2} \text { Prob_Dif }_{i t}+\beta_{3} \text { ESC }_{i t} \\
&+\lambda_{1} \text { Inv_Inst }_{i t}+ \lambda_{2} \text { Gov }_{i t}+\lambda_{3} \text { Rem }_{i t}+\lambda_{4} \text { Big }_{i t} \\
&+\delta_{1} \text { Ativo }_{i t}+\delta_{2} d 2011+\delta_{3} d 2012+\delta_{4} d 2013+v_{i t}
\end{aligned}
$$

$$
\begin{aligned}
& E S C_{i t}=\beta_{0}+\beta_{1} \text { Prob }_{i t}+\beta_{2} \text { Prob_Dif }_{i t} \\
& +\lambda_{1} \text { GOVERN }_{i t}+\lambda_{2} \text { Prob }_{i t} \times \text { GOVERN }_{i t}+\lambda_{3} \text { Prob_Dif }_{i t} \times \text { GOVERN }_{i t} \\
& +\delta_{1} \text { DCT }_{i t}+\delta_{2} \text { Endv }_{i t}+\delta_{3} \text { Ativo }_{i t}+\delta_{4} d 2011+\delta_{5} d 2012+\delta_{6} d 2013+\varepsilon_{i t} \\
& D C T A_{i t}=\beta_{0}+\beta_{1} \text { Prob }_{i t}+\beta_{2} \text { Prob_Dif }_{i t} \\
& +\lambda_{1} \text { GOVERN }_{i t}+\lambda_{2} \text { Prob }_{i t} \times \text { GOVERN }_{i t}+\lambda_{3} \text { Prob_Dif }_{i t} \times \text { GOVERN }_{i t} \\
& +\delta_{1} E S C_{i t}+\delta_{2} E_{n d v_{i t}}+\delta_{3} \text { Ativo }_{i t}+\delta_{4} d 2011+\delta_{5} d 2012+\delta_{6} d 2013+\varepsilon_{i t}
\end{aligned}
$$

onde:

Quadro 4 - Variáveis das Equações (32), (33), (34) e (35)

\begin{tabular}{|l|c|l|}
\hline Variável & $\begin{array}{c}\text { Sinal } \\
\text { Previsto }\end{array}$ & \multicolumn{1}{|c|}{ Definição } \\
\hline$E S C_{i t}$ & + & $\begin{array}{l}\text { Escolha contábil oportunista }(x) \text { da firma } i \text { no ano } t, \text { mensurada pelas } \\
\text { acumulações discricionárias, obtidas por meio do modelo Jones-Modificado, } \\
\text { equaços (36) e (37), apresentado na seção 4.5.2.1. }\end{array}$ \\
\hline$D C T A_{i t}$ & + & $\begin{array}{l}\text { Ajuste tributário anormal - evasão tributária }(y) \text { - da firma } i \text { no ano } t, \\
\text { mensurada pelas pelo resíduo da estimação da equação (38), apresentada na } \\
\text { seção 4.5.2.2. }\end{array}$ \\
\hline
\end{tabular}

Continua 
Conclusão

\begin{tabular}{|c|c|c|}
\hline Variável & $\begin{array}{c}\text { Sinal } \\
\text { Previsto }\end{array}$ & Definição \\
\hline Prob $_{i t}$ & - & $\begin{array}{l}\text { Taxa de auditoria (probabilidade de detecção) do setor da firma } i \text { no } t \text {, } \\
\text { transformada conforme (41) que é apresentada na seção 4.5.2.3. }\end{array}$ \\
\hline Prob_Difit & - & $\begin{array}{l}\text { Taxa de auditoria (probabilidade de detecção) das firmas sujeita ao } \\
\text { acompanhamento econômico-tributário diferenciado no } t \text {, transformada } \\
\text { conforme (41) que é apresentada na seção 4.5.2.3. }\end{array}$ \\
\hline Inv_Inst $t_{i t}$ & - & $\begin{array}{l}\text { É a proporção de investidores institucionais da firma } i \text { no ano } t \text {, em relação ao } \\
\text { total de investidores }\end{array}$ \\
\hline Gov $_{i t}$ & - & $\begin{array}{l}\text { Variável dummy que assume } 1 \text { se a firma } i \text { é listada em algum dos segmentos } \\
\text { de governança corporativa da BM\&FBOVESPA - Novo Mercado, Nível } 1 \text { ou } \\
\text { Nível } 2 .\end{array}$ \\
\hline $\operatorname{Rem}_{i t}$ & + & $\begin{array}{l}\text { Variável dummy que assume } 1 \text { se a firma } i \text { no ano } t \text { pagou remuneração } \\
\text { variável (resultado, bônus ou baseada em ações/opções) aos seus } \\
\text { administradores. }\end{array}$ \\
\hline Analist $_{i t}$ & $?$ & $\begin{array}{l}\text { Variável dummy que assume } 1 \text { se a firma } i \text { no ano } t \text { possuía cobertura de } \\
\text { analistas (pelo menos } 1 \text { ). }\end{array}$ \\
\hline Big4 ${ }_{i t}$ & - & $\begin{array}{l}\text { Variável dummy que assume } 1 \text { se a firma } i \text { no ano } t \text { foi auditada por uma Big } 4 \\
\text { (Deloitte, EY,KPMG ou } P W C \text { ). }\end{array}$ \\
\hline$E n d v_{i t}$ & $?$ & Endividamento da firma $i$ no ano $t$, dado por $\frac{\text { Dívida Bruta }}{\text { Ativo Total }}$ it \\
\hline Ativo $_{\text {it }}$ & + & Log natural do ativo total da firma $i$ no ano $t$ - variável de controle \\
\hline$G O V E R N_{i t}$ & - & $\begin{array}{l}\text { Variável dummy representativa da qualidade da governança corporativa, seja } \\
\text { pela presença de investidores institucionais, seja pela indicação de adesão aos } \\
\text { níveis de governança corporativa da BM\&FBovespa (Novo Mercado, Nível } \\
1 \text { ou Nível 2), individualmente, em duas estimações distintas. Na primeira } \\
\text { estimação, ela assume } 1 \text { na presença daqueles investidores. Na segunda, } \\
\text { assume } 1 \text { se a firma aderiu aos segmentos de governança da BM\&FBovespa. }\end{array}$ \\
\hline $\begin{array}{l}\operatorname{Prob}_{i t} x \\
\operatorname{GOVERN}_{i t}\end{array}$ & - & $\begin{array}{l}\text { Variável interativa. Segrega o efeito de } \operatorname{Prob}_{i t} \text { (coeficiente angular) para } \\
\text { aquelas firmas em que } G O V E R N_{i t}=1\end{array}$ \\
\hline $\begin{array}{l}\text { Prob_Difit } \\
x \\
\text { GOVERN } \\
\text { it }\end{array}$ & - & $\begin{array}{l}\text { Variável interativa. Segrega o efeito de } \text { Prob_Dif }_{i t} \text { (coeficiente angular) para } \\
\text { aquelas firmas em que } G O V E R N_{i t}=1\end{array}$ \\
\hline$d 2011$ & \multirow{3}{*}{ ? } & \multirow{3}{*}{$\begin{array}{l}\text { Variáveis dummies que assumem } 1 \text { se a observação se refere ao ano que } \\
\text { especificam. }\end{array}$} \\
\hline$d 2012$ & & \\
\hline$d 2013$ & & \\
\hline $\begin{array}{l}\beta^{\prime} s, \lambda ' s e \\
\delta^{\prime} s\end{array}$ & & Coeficientes das regressões \\
\hline$\varepsilon_{i t} e v_{i t}$ & & Termos de erro da firma $i$ no ano $t$. \\
\hline
\end{tabular}

Fonte: dados da pesquisa

Os modelos (32) e (33) foram utilizados para testar $H 1$ e $H 3$, respectivamente, e, conjuntamente, para testar $H 6$. A hipótese $H 4$ foi testada por meio do modelo (33), no entanto, 
com a utilização de $D C T$ ao invés de $D C T A$, como variável dependente. A evidência de associação negativa entre a probabilidade de detecção tributária e as escolhas contábeis oportunistas e os ajustes tributários totais e normais será observada se $\beta_{1}$ e/ou $\beta_{2}$ apresentarem sinais negativos e se mostrarem estatisticamente significativos. Já em relação a $H 6$, tem-se que ela será validada se $\beta_{3}$ for positivo e estatisticamente significativo, tanto em (32) quanto em (33). Especificamente em relação a $\beta_{2}$, os resultados referem-se às firmas diferenciadas.

Já para testar as hipóteses $H 2$ e $H 5$ foram empregados os modelos (34) e (35). Cada um deles estimado sob duas configurações. Na primeira, foi considerado como indicador da qualidade da governança corporativa a presença de investidores institucionais. Neste caso, $G O V E R N_{i t}=1$ se a firma contava com tais investidores. Na segunda configuração, aquela indicação é dada pela adesão da firma aos segmentos de governança corporativa da BM\&FBovespa. Se houve tal adesão, $G O V E R N_{i t}=1$.

O teste de $H 2$ e $H 5$ consiste, basicamente, na comparação entre os coeficientes $\beta_{1}$ e $\lambda_{2}$, bem como entre os coeficientes $\beta_{2}$ e $\lambda_{3}$. De acordo com tais hipótese, é esperado que $\lambda_{2}$ e $\lambda_{3}$ apresentem resultados inferiores aos de $\beta_{1}$ e $\beta_{2}$ (significância estatística, direção e magnitude).

\subsubsection{Estimações}

As estimações das equações (32), (33), (34) e (35) foram realizadas para toda a amostra e para cada decisão teoricamente definida no Capítulo 3. A estrutura de dados empregada foi a pooled cross section over time $e^{52}$, por isso o uso das variáveis dummies d2011, d2012 e d2013 nos modelos $^{53}$. Paulo (2007) utilizou essa estrutura e obteve resultados estatisticamente satisfatórios.

Para avaliar cada decisão teórica, a amostra foi condicionada de acordo com a configuração estabelecida para ESC e para DCTA, por exemplo, na análise da decisão 3, somente foram consideradas as observações em que ESC >0 e DCTA > 0 .

Contudo, no caso das decisões 1 e 2, as quais, teoricamente, consideram ESC $=0$ e $D C T A=0$, respectivamente, essas condições não puderam ser atendidas, de modo que a amostra foi condicionada apenas à $D C T A>0$, para a decisão 1 , e à $E S C<0$, no caso da decisão 2.

\footnotetext{
${ }^{52}$ Para detalhes ver Wooldridge (2002).

${ }^{53}$ É importante ter em mente que o pressuposto implícito na utilização de variáveis dummies é que as diferenças entre os grupos se refletem apenas no intercepto da reta de regressão, consequentemente, assume-se que as retas de tais grupos possuem o mesmo coeficiente angular (MADDALA, 2003).
} 
As equações (32) e (33) foram estimadas com a utilização da Regressão Quantílica (RQ). Essa técnica, que foi introduzida por Koenker e Basset (1978), oferece um campo mais amplo de investigação, pois pode fornecer informações sobre a relação entre as variáveis dependente e independentes ao longo da distribuição condicional da variável dependente, indo além da média condicional, como é possível com o uso do método dos Mínimos Quadrados Ordinários (MQO). Esse recurso mostra especialmente útil na presente pesquisa devido as evidências apresentadas por Armstrong et al. (2015), que sugerem que os efeitos da governança corporativa seriam diferenciados em relação ao nível da evasão tributária.

Além desse aspecto investigativo, uma vantagem da RQ é que ela é robusta aos problemas decorrentes da não normalidade dos erros (KOENKER; BASSET, 1978). Outro ponto importante é que a aplicação da RQ somente se mostra adequada na presença de heterocedasticidade, uma vez que essa é a razão da diferenciação entre os coeficientes ao longo dos quantis (CAMERON;TRIVEDI, 2009).

As estimações também foram realizadas com a utilização dos MQO ou dados em painel, conforme a indicação dos testes estatísticos. Na presença de endogeneidade, foi utilizado o método dos Mínimos Quadrados em Dois Estágios (MQ2E).

No sistema formado por (32) e (33), há duas variáveis endógenas: ESC e DCTA. A equação (32) é exatamente identificada, pois somente Big4 está ausente, enquanto (33) é sobreidentificada, uma vez que estão ausentes Analist e Endv. Para testar a hipótese nula de exogeneidade, foi utilizado o teste de Hausman (estatística $F$ ). Também foi utilizado o teste de Sargan para testar a hipótese nula de validade dos instrumentos utilizados, no caso de sobreidentificação.

Por fim, as estimações das equações (34) e (35) foram realizadas exclusivamente por meio da RQ.

\subsubsection{Definição das Variáveis}

\subsubsection{Escolhas Contábeis Oportunistas}

As acumulações discricionárias (AD) foram assumidas como proxy para as escolhas contábeis oportunistas. De acordo com Paulo (2007), muito embora não sejam observáveis, as $A D$ podem ser consideradas uma medida aproximada da anormalidade do resultado contábil e que, possivelmente, seriam uma resposta aos incentivos para a manipulação desse resultado.

As acumulações decorrem da adoção do regime de competência. Elas têm como função alterar o reconhecimento dos fluxos de caixa ao longo do tempo, a fim de melhor mensurar o 
desempenho da firma. Entretanto, como geralmente são baseadas em estimativas e julgamentos, as acumulações podem incorporar erros ou o oportunismo gerencial (DECHOW; DICHEV, 2002). Paulo (2007) lista diversos incentivos capazes de motivar a manipulação de informações contábeis, dentre eles, a redução da carga tributária.

As $A D$ foram obtidas pela diferença entre as Acumulações Totais (AT) e as Acumulações Não Discricionárias (AND), estimadas com base no modelo Jones modificado (DECHOW; SLOAN; SWEENEY, 1995). As $A T$, por sua vez, foram obtidas por meio da diferença entre o lucro antes do imposto de renda (LAIR) evidenciado na Demonstração do Resultado do Exercício (DRE) e o FCO, evidenciado na Demonstração dos Fluxos de Caixa (DFC).

O modelo Jones Modificado é dado por:

$$
A N D_{i t}=\hat{\alpha}_{1}\left(\frac{1}{A_{i t-1}}\right)+\hat{\alpha}_{2}\left(\frac{\Delta R_{i t}-\Delta R E C_{i t}}{A_{i t-1}}\right)+\hat{\alpha}_{3}\left(\frac{\operatorname{Imob}_{i t}}{A_{i t-1}}\right)
$$

onde:

$A N D_{i, t}=$ Acumulações Não Discricionárias da firma $i$ no ano $t ;$

$A_{i, t-1} \quad=$ Ativo total da firma $i$ no final do ano $t-1$

$\Delta R_{i, t} \quad=$ Variação das receitas líquidas da firma $i$ entre os anos $t$ e $t-1$

$\Delta R E C_{i, t}=$ Variação dos recebimentos líquidos da firma $i$ entre os anos $t$ e $t-1$

$\operatorname{Imob}_{i, t}=$ Ativo imobilizado (bruto) da firma $i$ no ano $t$.

Vale ressaltar que, seguindo a sistemática empregada por Dechow, Sloan e Sweeney (1995), os parâmetros $\hat{\alpha}_{1}, \hat{\alpha}_{2}$ e $\hat{\alpha}_{3}$, são estimados por meio do modelo proposto por Jones (1991), equação (37).

$$
\frac{A T_{i t}}{A_{i t-1}}=\alpha_{1}\left(\frac{1}{A_{i t-1}}\right)+\alpha_{2}\left(\frac{\Delta R_{i t}}{A_{i t-1}}\right)+\alpha_{3}\left(\frac{\operatorname{Imob}_{i t}}{A_{i t-1}}\right)+v_{i t}
$$

As equações (36) e (37) foram estimadas com base em cortes transversais (cross section) por ano-setor econômico, com o emprego dos MQO. Portanto, para cada ano, há um conjunto de 6 (seis) estimações, perfazendo um total de 24. Esse procedimento foi adotado visando 
preservar a formulação original do modelo, uma vez que a adição de variáveis dummies representativas dos anos analisados implicaria na inserção de interceptos para as estimações em tais anos.

\subsubsection{Evasão Tributária}

Mensurar o comportamento tributário da firma não é uma tarefa trivial. A principal limitação refere-se à indisponibilidade dos dados relativos à apuração tributária declarados para a autoridade (dados tributários). As firmas não divulgam tais informações de maneira detalhada e a autoridade tributária não os disponibiliza em razão da proteção constitucional do sigilo fiscal.

O fato é que essa limitação é um aspecto que deve ser considerado inerente às investigações empíricas que tratam de problemas relacionados à tributação da firma. Apesar dos erros de estimação, a saída para esse problema tem sido a utilização dos dados contábeis e financeiros, como pode ser visto em Mills (1996, 1998), Manzon e Plesko (2002), Phillips (2003), Plesko (2004), Desai e Dharmapala (2006a) e Hoopes, Mescall e Pittman (2012), por exemplo.

Especificamente em relação à mensuração da evasão tributária, a limitação também reside na dificuldade de segregar aquilo que é ou não infração à legislação tributária e, portanto, sujeito à penalidade. Trata-se de uma tarefa dificílima (talvez, impossível) de ser realizada com base em dados contábeis e financeiros, ainda mais se disponíveis de forma agregada.

Não obstante essa limitação, a literatura, a exemplo de Desai e Dharmapala (2006a), Frank, Lynch e Rego (2009), Tang (2011) e Tang e Firth (2011), tem oferecido alternativas que podem ser consideradas como proxies para a evasão tributária. Em sua maioria, são variantes da parcela anormal das DCT (DCTA), obtida sob uma sistemática semelhante à empregada na obtenção das $A D$.

A evasão tributária foi representada pelos ajustes tributários anormais, cuja proxy foram as DCTA, obtidas por meio da equação (38), a qual foi estimada para cada setor. Aqui também foi utilizada a estrutura pooled cross section over time.

$$
\begin{aligned}
\frac{D C T_{i t}}{A_{i t-1}}= & \alpha_{0}+\beta_{1} \frac{\Delta R_{i t}}{A_{i t-1}}+\beta_{2} \frac{I m o b_{i t}}{A_{i t-1}}+\beta_{3} \frac{I n v_{-} E P_{i t}}{A_{i t-1}}+\beta_{4} P J F 10+\beta_{5} \frac{A F D_{i t}}{A_{i t-1}}+ \\
& \beta_{6}\left(P J F 10_{i t} \times \frac{A F D_{i t}}{A_{i t-1}}\right)+\delta_{1} d 2011+\delta_{2} d 2012+\delta_{3} d 2013+\varepsilon_{i t}
\end{aligned}
$$


em que:

Quadro 5 - Variáveis da Equação (38)

\begin{tabular}{|c|c|}
\hline Variável & Definição \\
\hline$D C T_{i t}$ & Diferenças Contábil-Tributárias da firma $i$ no ano $t$. \\
\hline$\Delta R_{i t}$ & Variação da receita líquida da firma $i$ entre os anos $t-1$ e $t$. \\
\hline $\operatorname{Imob}_{\text {,it }}$ & Ativo imobilizado e ativo diferido da firma $i$ no ano $t$. \\
\hline$I n v_{-} E P_{i t}$ & $\begin{array}{l}\text { Somatório dos saldos dos investimentos avaliados pelo método da equivalência } \\
\text { patrimonial mantidos pela firma } i \text { no ano } t \text {. }\end{array}$ \\
\hline PJF10 & Número de anos em que a firma $i$ apresentou $L A I R<0$ nos 10 anos anteriores ao ano $t$. \\
\hline$A F D_{i t}$ & Ativo fiscal diferido da firma $i$ no ano $t$. \\
\hline$P J F 10_{i t} x A F D_{i t}$ & Saldo de prejuízo fiscal a compensar. \\
\hline$d 2011$ & \multirow{3}{*}{$\begin{array}{l}\text { Variáveis dummies que assumem } 1 \text { se a observação se refere ao ano que } \\
\text { especificam. }\end{array}$} \\
\hline$d 2012$ & \\
\hline$d 2013$ & \\
\hline$\alpha, \beta^{\prime} s$ e $\delta^{\prime} s$ & Coeficientes das regressões \\
\hline$\varepsilon_{i t}$ & Termo de erro da firma $i$ no ano $t$. \\
\hline
\end{tabular}

As DCT foram apuradas da seguinte maneira (MANZON; PLESKO, 2002; DESAI; DHARMAPALA, 2006a; MARTINEZ; FILHO; ANUNCIAÇÃO, 2013):

$$
D C T_{i t}=L A I R-\frac{I R_{-} C S L L \text { Correntes }_{i t}}{0,34}
$$

onde o LAIR é o lucro antes da tributação ("lucro antes do imposto de renda"). Na hipótese de $L A I R \leq 0$ e IR_CSLL Corrente $=0$, foi assumido $D C T=0$.

Sob a equação (39), as DCT agregam as diferenças temporárias e permanentes. Apesar de ser amplamente utilizada, uma limitação dessa medida é o fato de que somente reflete estratégias de não conformidade com o lucro contábil (HANLON; HEITZMAN, 2010).

Além disso, especialmente no contexto brasileiro, especificamente em relação ao período analisado, espera-se que, em todas firmas, uma parcela das $D C T$ seja decorrente dos ajustes específicos do $R T T$, dada a neutralidade tributária em relação aos IFRS assegurada por esse regime. Nesse sentido, Costa (2012) constatou que a adoção obrigatória da Lei $\mathrm{n}^{\circ}$ 11.638/2007 e a convergência total com os IFRS reduziram a conformidade contábil e tributária das firmas brasileiras de capital aberto. Sendo assim, é muito provável que as DCTA incorporem parte das diferenças do RTT. 
A inclusão das variáveis explicativas em (38) foi orientada pela potencial influência que cada uma delas exerceria sobre a parcela normal da $D C T$, considerando as características da legislação tributária do IRPJ e da CSLL. A fundamentação para tal inclusão é apresentada a seguir:

a) Variação da Receita Líquida $(\Delta R)$

Essas variações refletem as variações nas circunstâncias econômicas experimentadas pela firma (JONES, 1991), em função disso, elas podem capturar os efeitos destas variações refletidas nas $D C T$ e que não se relacionam à evasão tributária (TANG, 2011). Conforme argumentam Manzon e Plesko (2002), $\Delta R$ é uma variável importante para os modelos de estimação das acumulações não discricionários, sendo assim, é esperado que tais acumulações gerem diferenças em relação à tributação, devido as diferenças nos critérios de reconhecimento. A intuição é que variações positivas (crescimento) aumentem as DCT. Além disso, um aspecto interessante é que tais variações podem indicar firmas em crescimento. Tais firmas podem fazer mais investimentos em ativos dedutíveis que geram diferenças temporárias no reconhecimento das despesas para fins tributários e para fins de divulgação financeira.

No entanto, é preciso ter em mente que o nível de receita pode estar associado às estratégias tributárias da firma, dada a sensibilidade da carga tributária em relação a outros tributos incidentes sobre as receitas, tais como, PIS/Pasep e Cofins, e pelo fato de a receita (bruta) ser um dos parâmetros utilizados pela $R F B$ para a definição das firmas sujeitas ao acompanhamento econômico-tributário diferenciado. Por outro lado, em função justamente daquela sensibilidade e desse monitoramento, é possível que estratégias relacionadas diretamente às receitas não se mostrem uma alternativa interessante.

b) Imobilizado e Diferido (Imob)

A inclusão do imobilizado justifica-se pela existência de uma divergência natural entre os critérios de reconhecimento mensuração contábeis e tributários referentes à depreciação, que levam a diferenças temporárias normais (MANZON; PLESKO, 2002; TANG, 2011). Outrossim, tais diferenças também podem advir da adoção da depreciação acelerada ou, em alguns setores, da depreciação acelerada incentivada. Além disso, há também a possibilidade do reconhecimento de perdas por desvalorização 
(impairment), as quais também geram diferenças temporárias. Espera-se que boa parte das diferenças associadas ao imobilizado integrem o ajuste específico do RTT.

Já em relação ao diferido, a lógica é semelhante. Entretanto, em razão da alteração promovida pela Lei $\mathrm{n}^{\circ} 11.941 / 2009$ na Lei $\mathrm{n}^{\circ}$ 6.404/1976, a manutenção desse grupo foi opcional para fins societários ${ }^{54}$, muito embora tenha permanecido para fins tributários, em função do RTT. Isso cria um cenário mais complexo, pois há a possibilidade da existência de inúmeras configurações entre as dimensões societária e tributária, tanto pela existência ou não do diferido, como pela divergência entre os critérios de realização. Aqui, também é esperado que boa parte das divergências faça parte do ajuste específico do RTT.

c) Investimentos avaliados pelo $M E P($ Inv_EP $)$

Via de regra, os resultados da equivalência patrimonial não são tributados (dedutíveis) na apuração do IRPJ e da CSLL. Tratamento que também é aplicável aos valores referentes ao ágio (goodwill) e deságio (ganho por compra vantajosa) associados a tais investimentos, porém, neste caso, esses valores serão considerados na apuração do ganho de capital do investimento. Sendo assim, é muito provável que haja uma relação positiva entre o volume de investimentos avaliados pelo $M E P$ e as $D C T$ normais. Entretanto, é importante lembrar que esse tratamento é definido na perspectiva do balanço individual.

Vale salientar que o ágio (deságio) referente aos investimentos adquiridos no contexto de reorganização societária (incorporação, fusão ou cisão) é dedutível (tributável), nas hipóteses previstas na legislação. E é por isso que é preciso ter em mente que Inv_EP também pode capturar diferenças associadas a estratégias evasivas, tais como, as das operações de ágio interno, ágio de si mesmo etc.

\section{d) Prejuízo Fiscal (PJF10)}

A compensação de prejuízos fiscais ${ }^{55}$ de períodos anteriores integra as $D C T$ e pode representar um mecanismo importante na definição de estratégias tributárias, não

\footnotetext{
${ }^{54}$ Art. 299-A. O saldo existente em 31 de dezembro de 2008 no ativo diferido que, pela sua natureza, não puder ser alocado a outro grupo de contas, poderá permanecer no ativo sob essa classificação até sua completa amortização, sujeito à análise sobre a recuperação de que trata o § 3o do art. 183 desta Lei. (Lei no 6.404/107) ${ }^{55}$ A expressão "prejuízo fiscal" é empregada pela legislação tributária no âmbito do IRPJ, já para a CSLL é utilizada "base de cálculo negativa da CSLL". Por simplificação, as referências no texto relativas aos prejuízos fiscais alcançam também a CSLL.
} 
necessariamente evasivas (MANZON; PLESKO, 2002; BADERTSCHER ET AL., 2009). Entretanto, a informação sobre a existência de saldo de prejuízo fiscal, seu valor e a parcela efetivamente compensada a cada ano, não está disponível para a maioria das firmas analisadas.

Para superar esse problema, foi assumido que nos casos em que $L A I R<0$, a firma também teria apurado prejuízo fiscal. Como no Brasil a compensação de prejuízos fiscais de períodos anteriores é limitada a $30 \%$ do LAIR ajustado por adições e exclusões, a informação de maior relevância não é quanto foi utilizado, mas sim, se havia valores passíveis de compensação, pois, havendo, presume-se que as firmas compensariam até aquele limite.

Sob a lógica apresentada, PJF10 considera a ocorrência de $L A I R<0$, nos últimos dez anos (t-10 a $t-1)$, podendo variar de 0 a 10. Apesar das suas limitações, essa proxy é intuitiva, na medida em que, quanto maior o número de anos com $L A I R<0$, é razoável supor que maior seriam as chances de a firma apresentar saldo de prejuízo fiscal.

Por simplificação, bem como pela dificuldade de identificar e segregar os valores, é assumido que a existência de saldo de prejuízo fiscal de anos anteriores refere-se a prejuízos operacionais. Isso porque a utilização de saldo de prejuízos não operacionais de anos anteriores deve observar regras próprias, tais como, a compensação, exclusiva, com resultados não operacionais, nos termos da legislação tributária.

\section{e) $\underline{\text { Ativo Fiscal Diferido }(A F D)}$}

De acordo com o Pronunciamento Técnico CPC 32 - Tributos sobre o Lucro, o ativo fiscal diferido consiste no valor do tributo sobre lucro passível de recuperação/compensação em período futuro. Esse ativo pode contemplar: (a) diferenças temporárias dedutíveis; (b) prejuízos fiscais não utilizados; e (c) créditos fiscais não utilizados.

Dada a natureza desse elemento patrimonial, é possível assumir que ele esteja associado às $D C T$ normais, inclusive, ele pode ser considerado como um indicador da reversão de diferenças temporárias de períodos anteriores. Espera-se que haja uma associação positiva entre $A F D$ e $D C T$. 


\section{f) $\underline{\text { PJF10 }}$ AFD}

Essa interação buscou capturar a relação entre prejuízo fiscal e ativo fiscal diferido, uma vez que este contempla outras diferenças passíveis de dedução que não o prejuízo fiscal. $\mathrm{Na}$ verdade, trata-se de uma proxy para o saldo de prejuízos fiscais a compensar e complementa a informação fornecida por PJF10. Aqui também se espera uma relação positiva com as $D C T$.

\subsubsection{Probabilidade de Detecção Tributária}

As variáveis Prob e Prob_Dif são as proxies utilizadas para a probabilidade de a firma sujeitar-se a uma auditoria da $R F B$, as quais foram calculadas de acordo com (40). Essas variáveis representam a taxa de auditoria setorial (Prob) e a taxa de auditoria relacionada às firmas sujeitas ao acompanhamento diferenciado (Prob_Dif), respectivamente.

$$
\operatorname{Prob}(\text { Prob_Dif })=\frac{\text { quantidade de auditorias encerradas no ano } t}{\text { quantidade de firmas no ano } t}
$$

As quantidades de auditorias encerradas e de firmas no período analisado são evidenciadas na Tabela 3.

A fiscalização da $R F B$ tem adotado uma política de auditoria voltada fortemente para os maiores contribuintes, o que é perceptível ao analisar as taxas de auditoria apresentadas na Tabela 3. Além disso, nos últimos anos (2009 a 2014), os lançamentos de créditos tributários contra tais contribuintes tem correspondido a mais de $60 \%$ do total das autuações da RFB. Para se ter ideia, em 2013, o total desses créditos equivaleu a $84,1 \%$ das autuações realizadas nesse ano (RFB, 2015a).

Essa política impõe um maior nível de risco para os maiores contribuintes, o que se alinha com os fundamentos da hipótese do tamanho, assim, tem-se que, no Brasil, o tamanho influencia no grau de monitoramento tributário enfrentado pelas firmas. O que justifica a inclusão de Prob_Dif. 
Tabela 3 - Quantidades de Auditorias Encerradas e Quantidades de Firmas - 2010 a 2013

Painel A- Números Setoriais (continua)

\begin{tabular}{|c|c|c|c|c|}
\hline \multirow[t]{2}{*}{ Setores } & \multicolumn{4}{|c|}{$\begin{array}{c}\text { Taxas de Auditoria (Prob) } \\
\text { Auditorias Encerradas } \\
\text { (Quantidade de Firmas) }\end{array}$} \\
\hline & 2010 & 2011 & 2012 & 2013 \\
\hline \multirow{3}{*}{ Indústria } & 0,0099 & 0,0091 & 0,0068 & 0,0075 \\
\hline & 3.761 & 3.514 & 2.703 & 2.953 \\
\hline & $(378.416)$ & $(387.040)$ & $(394.585)$ & $(394.334)$ \\
\hline \multirow{3}{*}{ Comércio } & 0,0016 & 0,0013 & 0,0010 & 0,0011 \\
\hline & 3.436 & 3.005 & 2.277 & 2.449 \\
\hline & $(2.185 .524)$ & $(2.224 .035)$ & $(2.222 .219)$ & $(2.214 .867)$ \\
\hline \multirow{3}{*}{ Construção Civil } & 0,0044 & 0,0038 & 0,0027 & 0,0026 \\
\hline & 695 & 669 & 547 & 584 \\
\hline & $(155.634)$ & $(175.863)$ & (200.299) & $(221.083)$ \\
\hline \multirow{3}{*}{$\begin{array}{l}\text { Serviços de } \\
\text { Água e Energia }\end{array}$} & 0,0060 & 0,0055 & 0,0047 & 0,0050 \\
\hline & 105 & 106 & 101 & 115 \\
\hline & $(17.340)$ & (19.236) & $(21.348)$ & $(23.040)$ \\
\hline \multirow{3}{*}{$\begin{array}{l}\text { Transporte } \\
\text { relacionados }\end{array}$} & 0,0037 & 0,0037 & 0,0028 & 0,0026 \\
\hline & 725 & 779 & 652 & 635 \\
\hline & $(194.094)$ & (209.209) & $(228.499)$ & $(243.281)$ \\
\hline \multirow{3}{*}{ Outros } & 0,0031 & 0,0026 & 0,0019 & 0,0020 \\
\hline & 5.272 & 4.813 & 3.716 & 4.012 \\
\hline & $(1.713 .166)$ & $(1.809 .496)$ & $(1.897 .191)$ & $(1.967 .963)$ \\
\hline \multirow{3}{*}{ Total } & 0,0030 & 0,0027 & 0,0020 & 0,0022 \\
\hline & 13.994 & 12.886 & 9.996 & 10.748 \\
\hline & $(4.644 .174)$ & $(4.824 .879)$ & $(4.964 .141)$ & $(4.821 .287)$ \\
\hline
\end{tabular}

Painel B - Números das Firmas sujeitas ao Acompanhamento Econômico-Tributário Diferenciado

\begin{tabular}{lcccc}
\hline & \multicolumn{4}{c}{$\begin{array}{c}\text { Taxas de Auditoria (Prob_Dif) } \\
\text { Auditorias Encerradas } \\
\text { (Quantidade de Firmas) }\end{array}$} \\
\cline { 2 - 5 } Firmas Diferenciadas & 2010 & 2011 & 2012 & 2013 \\
\hline & 0,2676 & 0,2333 & 0,1891 & 0,2446 \\
& 2.828 & 2.835 & 2.383 & 2.931 \\
& $(10.568)$ & $(12.153)$ & $(12.600)$ & $(11.982)$ \\
\hline
\end{tabular}

Fonte: (1) Quantidade de auditorias encerradas: (i) relatórios "Resultados da Fiscalização", disponível em http://idg.receita.fazenda.gov.br/ dados/receitadata; e (ii) e-SIC - protocolos $\mathrm{n}^{\text {os }} 16853006496201519$ e 16853006497201563 , de 19/9/2015; e (2) Quantidade firmas: (i) relatório "Dados Setoriais - 2009/2013", disponível em http://idg.receita.fazenda.gov.br/ dados/receitadata; e (ii) e-SIC - protocolo no 16853007461201505 , de 28/10/2015

A fim de incorporar uma característica mais realista, Prob e Prob_Difforam submetidos à transformação não linear proposta por Tversky e Kahneman (1992), a qual resulta na superestimação da probabilidade de detecção tributária nos seus níveis mais baixos: 


$$
g(p)=\frac{p^{\gamma}}{\left[p^{\gamma}+(1-p)^{\gamma}\right]^{1 / \gamma}}
$$

em que $\gamma \in[0,1]^{56}$.

Seguindo a proposta de Bernasconi (1998), considerou-se que $\gamma=0,56$, valor também assumido por Siqueira (2004). Desse modo, as probabilidades utilizadas nesta pesquisa foram as evidenciadas na Tabela 4.

Tabela 4 - Probabilidades de Detecção Tributária

\begin{tabular}{|c|c|c|c|c|c|}
\hline & \multirow{2}{*}{ Setores } & \multicolumn{4}{|c|}{ Probabilidade de Detecção Tributária } \\
\hline & & 2010 & 2011 & 2012 & 2013 \\
\hline \multirow{6}{*}{ Prob } & Indústria & 0,0669 & 0,0640 & 0,0555 & 0,0581 \\
\hline & Comércio & 0,0257 & 0,0237 & 0,0204 & 0,0213 \\
\hline & Construção Civil & 0,0446 & 0,0410 & 0,0345 & 0,0339 \\
\hline & $\begin{array}{l}\text { Serviços de Comunicação, Água e } \\
\text { Energia }\end{array}$ & 0,0522 & 0,0469 & 0,0459 & 0,0472 \\
\hline & Transporte e serviços relacionados & 0,0406 & 0,0405 & 0,0353 & 0,0336 \\
\hline & Outros & 0,0367 & 0,0340 & 0,0289 & 0,0295 \\
\hline Prob_Dif & Diferenciadas & 0,2919 & 0,2754 & 0,2523 & 0,2809 \\
\hline
\end{tabular}

Fonte: dados da pesquisa

Para cada firma, foi atribuído o valor de Prob conforme o respectivo setor econômico. Sendo a firma classificada como diferenciada, Prob_Dif assumiu o valor evidenciado acima, do contrário, Prob_Dif $=0$.

É importante salientar que Prob e Prob_Dif não representam a percepção de risco dos agentes, ao invés disso, consistem na indicação do nível médio da atuação fiscalizatória da autoridade. E essa é uma limitação significativa. Contudo, a despeito da subjetividade, assumese que esse nível de atuação estaria relacionado à percepção de risco dos agentes, o que é algo factível.

\footnotetext{
56 Tversky e Kahneman (1992) estimaram $\gamma=0,61$ para os ganhos e $\gamma=0,69$ para as perdas. Já Carmerer e Ho (1994) estimaram $\gamma=0,56$, enquanto em Wu e Gonzales (1996) $\gamma=0,71$.
} 


\subsubsection{Governança Corporativa (Inv_Inst e Gov)}

A literatura tem demonstrado que os mecanismos de governança corporativa restringem o nível de acumulações discricionárias (oportunismo gerencial) (MARTINEZ, 2001; BARROS; SOARES; LIMA, 2013; MAN; WONG, 2013), assim como afetariam o comportamento tributário das firmas (DESAI; DHARMAPALA, 2006a, 2009a; DESAI; DICK; ZINGALES, 2007; CHEN ET AL., 2010; LANIS; RICHARDSON, 2011, 2013; MARTINEZ; RAMALHO, 2014).

Dada a hipótese da complementaridade, esses mecanismos restringiriam o oportunismo gerencial e, sob um nível suficientemente elevados de custos de detecção, também reduziriam as estratégias de evasão tributária. A investigação dessa hipótese é a motivação para inclusão dessas variáveis nos modelos (32) e (33), bem como a estimação dos modelos (34) e (35).

Inv_Inst é a proporção de investidores institucionais da fïma. Esses investidores tendem a ser mais sofisticados, do ponto de vista informacional, uma vez que possuem elevada capacidade de monitoramento do desempenho dos gestores. Como realizam investimentos significativos, há incentivos para realizar tal monitoramento e exercer pressão visando garantir o retorno desses investimentos. Desse modo, os investidores institucionais podem ser associados às boas práticas de governança corporativa (FERRI; SOARES, 2009; MAN; WONG, 2013).

Gové a variável dummy que assume 1 se a firma pertence aos segmentos Novo Mercado ou aos Níveis 1 e 2 de governança da BM\&FBOVESPA. Parte-se da premissa que tais firmas possuem governança de melhor qualidade, pois adotam práticas que oferecem maior transparência e segurança para os investidores, sobretudo os minoritários.

Para tais variáveis, espera-se que seja verificada uma associação negativa tanto com ESC quanto com DCTA.

\subsubsection{Remuneração Variável (Rem)}

Rem é a variável dummy que assume 1 se a firma paga remuneração variável aos seus administradores, tais como, participação nos lucros, bônus ou remuneração baseada em ações/opções. Esse tipo de remuneração pode oferecer incentivos para os agentes atuarem oportunisticamente, por outro lado, pode permitir um maior alinhamento de interesses entre esses indivíduos e o principal, sobretudo se a firma contar com mecanismos de governança eficientes. 
Sob a hipótese do plano de bonificação (bônus plan hypothesis), tem-se que os agentes de firmas que adotam contratos de compensação estariam mais propensos a realizar escolhas contábeis que antecipem lucros futuros (WATTS; ZIMMERMAN, 1986)

Healy (1985), entretanto, demonstra que essa relação não seria tão simples, pois envolve a natureza do contrato de bonificação e a configuração das metas gerenciais, de modo que os esquemas de compensação também podem oferecer incentivos para antecipar perdas e, assim, reduzir o resultado contábil.

Em relação à evasão tributária, Desai e Dharmapala (2006a) demonstram, teoricamente, que aumentos na remuneração variável do agente, em firmas com governança corporativa de baixa qualidade, ofereceria incentivos para a adoção de estratégias evasivas como um mecanismo adicional de oportunismo gerencial, desde que o risco de detecção seja baixo.

Sendo assim, espera-se que Rem seja positivamente associado à DCTA nas firmas com governança fraca, por outro lado, tanto para as firmas com governança forte, como para aquelas sujeitas ao acompanhamento diferenciado, espera-se que essa relação seja negativa ou positiva e insignificante estatisticamente. Já quanto a $E S C$, não é possível prever a direção de tal relação.

\subsubsection{Cobertura de Analistas (Analist)}

A cobertura de analistas pode potencializar os custos de divulgação financeira da firma, na medida em que pode representar um mecanismo de monitoramento externo e, assim, seria capaz de reduzir o oportunismo gerencial. Essa conclusão pode ser extraída de Yu (2008), cujos resultados indicam que haveria uma associação negativa entre número de analistas que seguem a firma e a probabilidade de gerenciamento de resultados. Martinez (2011) apresenta resultados semelhantes para o cenário brasileiro

Entretanto, também no Brasil, Vasconcelos et al. (2008) verificaram que não haveria uma relação significativa entre as acumulações discricionárias e a cobertura das empresas de rating, o que, tangencialmente, contraria Martinez (2011). Contrariamente, também, há evidências em nível internacional que indicam que agentes praticaram o gerenciamento de resultados visando bater as previsões dos analistas, ou seja, a cobertura de analistas teria oferecido incentivos para o oportunismo (DHALIWAL; GLEASON; MILLS, 2004; GUPTA; LAUX; LYNCH, 2015).

A linha preferencialmente assumida nesta pesquisa é que a cobertura de analistas restringe o oportunismo gerencial. Essa cobertura é mensurada pela variável Analist, variável 
dummy que assume 1 se a firma é acompanhada por analistas (pelo menos 1). Espera-se que essa variável apresente relação negativa com ESC.

\subsubsection{Qualidade da Auditoria (Big4)}

A literatura tem apresentado evidências, diretas e indiretas, contraditórias sobre os efeitos da qualidade da auditoria sobre o nível de acumulações discricionárias das firmas (BECKER ET AL., 1998; LAWRENCE; MINUTTI-MEZA; ZHANG, 2011; AL-MOUSAWI; AL-THUNEIBAT, 2011; AZEVEDO; COSTA, 2012; YASAR, 2013)

Do mesmo modo, uma linha de pesquisa mais recente também tem apresentado resultados contraditórios sobre os efeitos das características da auditoria independente, dentre elas a sua qualidade e a contratação de seus serviços tributários, sobre o comportamento tributário das firmas (HOGAN; NOGA, 2012; MCGUIRE; OMER; WANG, 2012; NOH; MOON; GUIRAL, 2014; SERAFAT; BARZEGAR, 2015).

Big4 é a variável indicativa da qualidade da auditoria da firma. Trata-se de uma variável dummy que assume 1, caso a firma tenha sido auditada pela Deloitte, Ernest \& Young (EY), KPMG ou PricewaterhouseCoopers (PWC). Essa variável somente foi incluída no modelo (33), cujo intuito foi controlar possíveis efeitos da auditoria sobre o comportamento tributário da firma e figurar como variável instrumental na hipótese de endogeneidade de $E S C$ em relação à DCTA, uma vez que inclusão de Big4 em ambos os modelos implicaria na subidentificação de (33). Outrossim, essa inclusão permitiu avaliar se aqueles efeitos são significativos no cenário brasileiro. Trata-se de uma incursão exploratória, de modo que não há uma expectativa quanto à direção da sua relação com DCTA.

\subsubsection{Nível de Endividamento (Endv)}

Essa variável busca capturar os incentivos relacionados ao nível de endividamento da firma. Watts e Zimmerman (1986) formulam a hipótese do endividamento, sob a qual os gerentes de firmas que apresentam maior endividamento estariam mais propensos a realizar escolhas contábeis que antecipassem, oportunisticamente, lucros de períodos futuros. Conforme argumenta Paulo (2007), os incentivos para esse comportamento adviriam do risco de violação das cláusulas contratuais de dívida (debt convenants), uma vez que tal violação impõe custos adicionais para a firma, tais como o aumento no custo do capital e demais restrições na renovação desses contratos. 
A literatura tem demonstrado a existência de uma relação negativa entre o nível de endividamento e a tributação efetiva da firma, a qual seria decorrente dedutibilidade das despesas financeiras, o que representaria um dos fatores mais relevantes para as decisões de financiamento e de definição de uma estrutura ótima de capital (STICKNEY; MCGEE, 1982; GUPTA; NEWBERRY, 1997; POHLMANN, IUDÍCIBUS, 2010; SANTOS; CAVALCANTE; RODRIGUES, 2013). Contudo, vale salientar que, justamente em razão dessa dedutibilidade, o nível de endividamento não estaria relacionado às $D C T$, por isso ele não foi incluído no modelo (33).

Seguindo a teoria, espera-se que o endividamento esteja positivamente associado com o nível de acumulações discricionárias. No entanto, é preciso ter em mente que o endividamento, necessariamente, não reflete o risco de violação das cláusulas contratuais, por isso, é possível que seja observado um resultado diferente. 


\section{RESULTADOS DA ETAPA EMPÍRICA DA PESQUISA}

\subsection{Mensuração das Escolhas Contábeis Oportunistas (ESC)}

As escolhas contábeis oportunistas (ESC) foram mensuradas por meio das acumulações discricionárias (anormais), as quais foram obtidas pela diferença entre as AT (acumulações totais) e as AND (acumulações não-discricionárias) estimadas pelo modelo Jones Modificado. Tais estimações foram realizadas para cada setor considerado nesta pesquisa, em cada um dos anos analisados. A Tabela 5 apresenta as estatísticas descritivas das ESC obtidas e das variáveis utilizadas naquele modelo.

Tabela 5 - Estatísticas Descritivas - Variáveis do Modelo Jones Modificado

Painel A - Amostra total

\begin{tabular}{lcccccccc}
\hline Variáveis & Média & $\begin{array}{c}\text { Desvio } \\
\text { Padrão }\end{array}$ & Mínimo & Q05 & Q50 & Q95 & Máximo & $>0$ \\
\hline$A T$ & $-0,044$ & 0,389 & $-5,819$ & $-0,229$ & $-0,010$ & 0,179 & 1,050 & $45,42 \%$ \\
$\Delta R$ & 0,038 & 0,265 & $-4,917$ & $-0,138$ & 0,010 & 0,277 & 3,440 & - \\
Imob & 0,272 & 0,480 & 0,000 & 0,000 & 0,149 & 0,826 & 9,529 & - \\
AReceb & 0,007 & 0,051 & $-0,282$ & $-0,049$ & 0,000 & 0,066 & 0,619 & - \\
ESC & 0,079 & 0,445 & $-5,369$ & $-0,192$ & 0,039 & 0,574 & 5,368 & $64,67 \%$ \\
\hline
\end{tabular}

Painel B - Setor 1: Indústria

\begin{tabular}{lcccccccc}
\hline Variáveis & Média & $\begin{array}{c}\text { Desvio } \\
\text { Padrão }\end{array}$ & Mínimo & Q05 & Q50 & Q95 & Máximo & $>0$ \\
\hline$A T$ & $-0,082$ & 0,474 & $-5,726$ & $-0,336$ & $-0,008$ & 0,140 & 1,050 & $46,61 \%$ \\
$\Delta R$ & 0,027 & 0,379 & $-4,917$ & $-0,240$ & 0,010 & 0,327 & 3,440 & - \\
Imob & 0,324 & 0,273 & 0,000 & 0,038 & 0,273 & 0,760 & 3,266 & - \\
$\Delta$ Receb & 0,007 & 0,058 & $-0,282$ & $-0,068$ & 0,002 & 0,083 & 0,619 & - \\
ESC & 0,213 & 0,588 & $-2,948$ & $-0,184$ & 0,108 & 1,063 & 5,368 & $80,82 \%$ \\
\hline
\end{tabular}

Painel C - Setor 2: Comércio

\begin{tabular}{lcccccccc}
\hline Variáveis & Média & $\begin{array}{c}\text { Desvio } \\
\text { Padrão }\end{array}$ & Mínimo & Q05 & Q50 & Q95 & Máximo & $>0$ \\
\hline$A T$ & 0,038 & 0,118 & $-0,238$ & $-0,116$ & 0,033 & 0,191 & 0,629 & $70,00 \%$ \\
$\Delta R$ & 0,150 & 0,352 & $-0,418$ & $-0,095$ & 0,082 & 0,704 & 2,051 & - \\
Imob & 0,141 & 0,113 & 0,000 & 0,000 & 0,127 & 0,326 & 0,476 & - \\
$\Delta$ Receb & 0,020 & 0,060 & $-0,118$ & $-0,053$ & 0,002 & 0,144 & 0,281 & - \\
ESC & $-0,003$ & 0,079 & $-0,266$ & $-0,125$ & 0,007 & 0,112 & 0,203 & $53,33 \%$ \\
\hline
\end{tabular}

Continua.

$\boldsymbol{A T}$ representa as acumulações totais do ano $t ; \boldsymbol{\Delta R}$ é a variação das receitas líquidas anuais do ano $t$ 1 para o ano $t$; Imob é o somatório dos saldos finais brutos, do ano $t$, do ativo imobilizado e do ativo diferido; $\Delta$ Receb é a variação dos recebíveis do ano $t-1$ para o ano $t$. Todas essas variáveis são escalonadas pelo ativo total do ano $t-1 ; \boldsymbol{E S C}$ é a proxy para as escolhas contábeis oportunistas, mensurada com base no modelo Jones Modificado. Número de observações: (i) amostra total - 951; (ii) setor 1-339; (iii) setor 2- 60; (iv) setor 3-72; (v) setor 4-164; (vi) setor 5-160; e (vii) setor $6-156$. 
Tabela 5 - Estatísticas Descritivas - Variáveis do Modelo Jones Modificado

Painel D - Setor 3: Construção Civil

\begin{tabular}{lcccccccc}
\hline Variáveis & Média & $\begin{array}{c}\text { Desvio } \\
\text { Padrão }\end{array}$ & Mínimo & Q05 & Q50 & Q95 & Máximo & $>0$ \\
\hline$A T$ & 0,063 & 0,182 & $-0,532$ & $-0,199$ & 0,049 & 0,311 & 0,684 & $67,12 \%$ \\
$\Delta R$ & 0,029 & 0,111 & $-0,084$ & $-0,041$ & 0,000 & 0,209 & 0,691 & - \\
Imob & 0,075 & 0,209 & 0,000 & 0,000 & 0,005 & 0,883 & 0,934 & - \\
$\Delta R e c e b$ & 0,010 & 0,057 & $-0,136$ & $-0,080$ & 0,000 & 0,095 & 0,265 & - \\
$E S C$ & 0,059 & 0,175 & $-0,414$ & $-0,233$ & 0,056 & 0,319 & 0,574 & $65,75 \%$ \\
\hline
\end{tabular}

Painel E - Setor 4: Serviços de Comunicação, Água e Energia

\begin{tabular}{lcccccccc}
\hline Variáveis & Média & $\begin{array}{c}\text { Desvio } \\
\text { Padrão }\end{array}$ & Mínimo & Q05 & Q50 & Q95 & Máximo & 0> \\
\hline$A T$ & $-0,028$ & 0,073 & $-0,361$ & $-0,142$ & $-0,021$ & 0,083 & 0,172 & $26,22 \%$ \\
$\Delta R$ & 0,005 & 0,073 & $-0,589$ & $-0,070$ & 0,002 & 0,131 & 0,165 & - \\
Imob & 0,251 & 0,326 & 0,000 & 0,000 & 0,030 & 0,844 & 1,316 & - \\
$\Delta$ Receb & $-0,002$ & 0,028 & $-0,215$ & $-0,034$ & 0,000 & 0,028 & 0,169 & - \\
ESC & $-0,006$ & 0,071 & $-0,354$ & $-0,096$ & $-0,006$ & 0,109 & 0,172 & $44,51 \%$ \\
\hline
\end{tabular}

Painel F - Setor 5: Transportes e serviços relacionados

\begin{tabular}{lcccccccc}
\hline Variáveis & Média & $\begin{array}{c}\text { Desvio } \\
\text { Padrão }\end{array}$ & Mínimo & Q05 & Q50 & Q95 & Máximo & 0> \\
\hline$A T$ & $-0,094$ & 0,588 & $-5,819$ & $-0,180$ & $-0,032$ & 0,177 & 0,309 & $35,00 \%$ \\
$\Delta R$ & 0,065 & 0,105 & $-0,083$ & $-0,037$ & 0,027 & 0,304 & 0,506 & - \\
Imob & 0,275 & 0,643 & 0,000 & 0,000 & 0,032 & 0,820 & 7,103 & - \\
$\Delta R e c e b$ & 0,002 & 0,016 & $-0,120$ & $-0,014$ & 0,001 & 0,027 & 0,053 & - \\
ESC & $-0,029$ & 0,568 & $-5,369$ & $-0,194$ & 0,000 & 0,377 & 0,909 & $50,00 \%$ \\
\hline
\end{tabular}

Painel G - Setor 6: Outros

\begin{tabular}{lcccccccc}
\hline Variáveis & Média & $\begin{array}{c}\text { Desvio } \\
\text { Padrão }\end{array}$ & Mínimo & Q05 & Q50 & Q95 & Máximo & 0> \\
\hline$A T$ & $-0,008$ & 0,207 & $-1,033$ & $-0,291$ & 0,004 & 0,250 & 0,460 & $53,85 \%$ \\
$\Delta R$ & 0,031 & 0,199 & $-0,175$ & $-0,148$ & 0,005 & 0,277 & 1,348 & - \\
Imob & 0,321 & 0,810 & 0,000 & 0,000 & 0,107 & 0,863 & 9,529 & - \\
$\Delta R e c e b$ & 0,012 & 0,064 & $-0,091$ & $-0,028$ & 0,000 & 0,099 & 0,469 & - \\
ESC & 0,029 & 0,199 & $-0,980$ & $-0,217$ & 0,053 & 0,274 & 0,562 & $69,23 \%$ \\
\hline
\end{tabular}

$\boldsymbol{A T}$ representa as acumulações totais do ano $t ; \boldsymbol{\Delta R}$ é a variação das receitas líquidas anuais do ano $t$ 1 para o ano $t$; Imob é o somatório dos saldos finais brutos, do ano $t$, do ativo imobilizado e do ativo diferido; $\Delta$ Receb é a variação dos recebíveis do ano $t$-1 para o ano $t$. Todas essas variáveis são escalonadas pelo ativo total do ano $t-1 ; \boldsymbol{E S C}$ é a proxy para as escolhas contábeis oportunistas, mensurada com base no modelo Jones Modificado. Número de observações: (i) amostra total - 951; (ii) setor 1-339; (iii) setor 2- 60; (iv) setor 3-72; (v) setor 4-164; (vi) setor 5-160; e (vii) setor 6- 156 .

Fonte: dados da pesquisa. 
$\mathrm{Na}$ amostra total, observa-se uma maior ocorrência de $A T<0(54,58 \%)$ e de $E S C>0$ $(64,67 \%)$, o que é refletido nas respectivas médias. Isso sugere que, no período analisado, as firmas, na média, teriam experimentado reduções no resultado em razão de $A N D<0$ e que teriam exercido escolhas contábeis oportunistas que anularam ou mitigaram esse efeito.

Entretanto, ao longo dos setores, essa configuração não se manteve, o que é algo esperado, haja vista as diferenças entre as distribuições das variáveis explicativas do modelo Jones Modificado ${ }^{57}$, as quais são reflexos das particularidades de cada setor. Por exemplo, os setores 1 (indústria), 4 (Serviços de Comunicação, Água e Energia), 5 (Transportes e serviços relacionados) e 6 (Outros), exibem maior Imob médio, já o setor 2 (Comércio) apresenta a maior média para $\Delta R$ e $\Delta R e c e b$, enquanto o setor 4 apresenta o menor nível para tais variáveis, inclusive com $\Delta$ Receb $<0$.

Outrossim, os setores 1, 3 (Construção Civil) e 6, apresentam ESC média > 0, com destaque para o setor 1, que apresenta a maior média e a maior ocorrência de $E S C>0$, acima de $80 \%$ das observações. Já os setores 2, 4 e 5, exibem ESC média < 0, sendo que nos setores 4 e 5 também há uma maior presença de $A T<0$, superior a $60 \%$ das observações, e médias setoriais também negativas.

As diferenças setoriais contidas em ESC são refletidas por meio dos coeficientes obtidos com base no modelo Jones, os quais foram utilizados nas estimações das AND com o emprego do modelo Jones Modificado. A Tabela 6 apresenta esses coeficientes para cada estimação setor-ano.

Tabela 6 - Coeficientes - Modelo Jones

Painel A - 2010

\begin{tabular}{lcccccc}
\hline & \multicolumn{5}{c}{ Coeficientes } \\
\cline { 2 - 6 } & Setor 1 & Setor 2 & Setor 3 & Setor 4 & Setor 5 & Setor 6 \\
\hline $1 / A_{i t-1}$ & $-4,44 \times 10^{6}$ & $-2,03 \times 10^{5^{* *}}$ & $-4,09 \times 10^{6 * * *}$ & $-1,25 \times 10^{7 * * *}$ & $-5,48 \times 10^{5}$ & $-9,61 \times 10^{5}$ \\
$\Delta R_{i t}$ & $-0,022$ & 0,059 & $0,568^{* * *}$ & $-0,432^{* * * *}$ & $-0,070$ & $0,287^{* * *}$ \\
Imob $_{\text {it }}$ & $-0,193^{*}$ & $0,171^{* * *}$ & $1,499^{* *}$ & $-0,017$ & 0,007 & $-0,127$ \\
\hline Estatística $F$ & $2,22^{*}$ & $5,24^{* *}$ & $9,86^{* * *}$ & $6,75^{* * *}$ & 2,22 & $11,11^{* * *}$ \\
$R^{2}$ ajustado & 0,2807 & 0,1056 & 0,2190 & 0,4854 & $-0,0337$ & 0,1781 \\
\hline
\end{tabular}

\footnotetext{
57 As variáveis constantes na Tabela 5 apresentam médias estatisticamente diferentes entre os setores. Os testes realizados, cujos resultados não são apresentados, indicam que as diferenças são significativas a 1\%, com exceção da variável $\Delta R e c e b$, que apresentou significância a $5 \%$.
} 
Tabela 6 - Coeficientes - Modelo Jones

Painel B - 2011

\begin{tabular}{lcccccc}
\hline & \multicolumn{6}{c}{ Coeficientes } \\
\cline { 2 - 7 } & Setor 1 & Setor 2 & Setor 3 & Setor 4 & Setor 5 & Setor 6 \\
\hline $1 / A_{\text {it- } 1}$ & $-1,83 \times 10^{7 *}$ & $4,10 \times 10^{6^{* * * *}}$ & $-7,56 \times 10^{6 * * *}$ & $-5,96 \times 10^{6^{* *}}$ & $1,18 \times 10^{5}$ & $2,29 \times 10^{5}$ \\
$\Delta R_{\text {it }}$ & $0,285^{* *}$ & 0,005 & $2,546^{* * *}$ & $-0,107$ & $-0,494^{*}$ & 0,038 \\
Imob $_{\text {it }}$ & $-0,232$ & 0,229 & $1,217^{*}$ & $-0,036^{*}$ & $-0,036$ & $-0,131$ \\
\hline Estatística $F$ & $2,48^{*}$ & $59,27^{* * *}$ & $7,85^{* * *}$ & $4,11^{* *}$ & $2,77^{* *}$ & $2,37^{*}$ \\
$R^{2}$ ajustado & 0,2488 & 0,1096 & 0,3450 & 0,1702 & 0,1079 & 0,0557 \\
\hline
\end{tabular}

Painel C - 2012

\begin{tabular}{lcccccc}
\hline & \multicolumn{6}{c}{ Coeficientes } \\
\cline { 2 - 7 } & Setor 1 & Setor 2 & Setor 3 & Setor 4 & Setor 5 & Setor 6 \\
\hline $1 / A_{\text {it-1 }}$ & $-1,98 \times 10^{7 * *}$ & $2,24 \times 10^{6 * * *}$ & $3,17 \times 10^{7}$ & $-2,69 \times 10^{6}$ & $-1,42 \times 10^{6}$ & $3,48 \times 10^{5}$ \\
$\Delta R_{\text {it }}$ & 0,069 & $0,085^{* * *}$ & $1,232^{* *}$ & $-0,196$ & 2,098 & 0,295 \\
Imob $_{\text {it }}$ & $-0,196$ & 0,036 & $-0,008$ & $-0,027$ & $-0,449$ & $-0,250^{*}$ \\
\hline Estatística $F$ & 2,14 & $42,56^{* * *}$ & $7,31^{* * *}$ & 1,75 & 0,44 & $2,51^{*}$ \\
$R^{2}$ ajustado & 0,2433 & 0,2026 & 0,1449 & 0,0080 & 0,0590 & 0,1499 \\
\hline
\end{tabular}

Painel D - 2013

\begin{tabular}{lcccccc}
\hline & \multicolumn{6}{c}{ Coeficientes } \\
\cline { 2 - 7 } & Setor 1 & Setor 2 & Setor 3 & Setor 4 & Setor 5 & Setor 6 \\
\hline $1 / A_{i t-1}$ & $-3,56 \times 10^{7 * * *}$ & $2,02 \times 10^{7 * * *}$ & $3,04 \times 10^{7}$ & $6,92 \times 10^{6 * * *}$ & $-2,49 \times 10^{6}$ & $-8,02 \times 10^{5}$ \\
$\Delta R_{i t}$ & $0,261^{* * *}$ & $-0,007$ & $-0,696$ & $0,425^{*}$ & $-0,026^{*}$ & $0,766^{* *}$ \\
Imob $_{\text {it }}$ & $-0,124$ & $-0,073$ & $-1,163$ & $-0,060$ & $-0,535$ & $-0,041$ \\
\hline Estatística $F$ & $92,08^{* * *}$ & $1.185,75^{* * *}$ & 0,34 & $43,97^{* * *}$ & 0,45 & 1,68 \\
$R^{2}$ ajustado & 0,7111 & 0,9001 & 0,0733 & 0,1975 & 0,0312 & 0,0187 \\
\hline
\end{tabular}

Modelo Jones: $\frac{A T_{i t}}{A_{i t-1}}=\alpha_{1}\left(\frac{1}{A_{i t-1}}\right)+\alpha_{2}\left(\frac{\Delta R_{i t}}{A_{i t-1}}\right)+\alpha_{3}\left(\frac{I M O B_{i t}}{A_{i t-1}}\right)+v_{i t}$

$\boldsymbol{A} \boldsymbol{T}_{i t}$ representa as acumulações totais da firma i no ano $t ; \boldsymbol{\Delta} \boldsymbol{R}_{i t}$ é a variação das receitas líquidas anuais do ano $t-l$ para o ano $t$ da firma $i$; e Imob $\boldsymbol{I}_{t}$ é o somatório dos saldos finais brutos, do ano $t$, do ativo imobilizado e do ativo diferido da firma $i$. Essas variáveis são escalonadas pelo ativo total do ano $t$ - 1 . As regressões foram estimadas com erros padrão robustos. Número de observações: (i) setor 1: Indústria - 85; (ii) setor 2: Comércio - 15; (iii) setor 3: Construção Civil - 18; (iv) setor 4: Serviços de Comunicação, Água e Energia - 41; (v) setor 5: Transportes e serviços relacionados - 40; e (vi) setor 6: Outros - 39. *, ** e *** indicam a significância estatística bicaudal a $10 \%, 5 \%$; e $1 \%$, respectivamente.

Fonte: dados da pesquisa.

De uma maneira geral, as estimações apresentam ajustes satisfatórios, muito embora para alguns agrupamentos setor-ano isso não seja observado, notadamente para o setor 5 , cuja Estatística $F$ não se mostrou significativa para 3 dos 4 anos. Sem dúvida esse é um aspecto negativo, sobretudo no que se refere ao poder estatístico dos modelos e à generalização dos resultados. Contudo, como o objetivo das estimações é a obtenção dos coeficientes para cálculo 
das $E S C^{58}$, de forma restrita à amostra analisada, sem qualquer pretensão de generalização, essas limitações tendem a não ser impeditivas.

Quanto à normalidade das distribuições setoriais de ESC, a Tabela 7 apresenta os resultados do respectivo teste estatístico.

Tabela 7 - Normalidade de ESC

\begin{tabular}{ccc}
\hline & Estatística & p-valor \\
\hline Setor 1 & $555,988^{* * *}$ & $(0,0000)$ \\
Setor 2 & $12,960^{* * *}$ & $(0,0015)$ \\
Setor 3 & 2,291 & $(0,3181)$ \\
Setor 4 & $38,632^{* * *}$ & $(0,0000)$ \\
Setor 5 & $3215,916^{* * *}$ & $(0,0000)$ \\
Setor 6 & $85,532^{* * *}$ & $(0,0000)$ \\
Amostra Total & $6106,403^{* * *}$ & $(0,0000)$ \\
Teste de Doornik-Hansen. $H_{0}:$ a & distribuição é normal. \\
*** significância estatística a 1\%. \\
Fonte: dados da pesquisa
\end{tabular}

Como é possível verificar, ESC somente apresenta distribuição normal no setor 3. Embora a normalidade seja uma característica desejável ou até mesmo fundamental, em alguns casos, sobretudo em relação ao emprego das estatísticas $F$ e $t$, aqui ela será relaxada pelas seguintes razões: (1) a amostra possui um tamanho reduzido, o que impede a realização de ajustes, tais como, a eliminação de valores extremos, sem agravar ainda mais essa restrição; (2) apesar das suas limitações, o modelo Jones Modificado tem sido validado pela literatura (FRANK; LYNCH; REGO, 2009; HANLON; HOOPES; SHROFF, 2014); (3) a aplicação da lei dos grandes números e do teorema do limite central (WOOLDRIDGE, 2002; BROOKS, 2008); (4) as estimações não serão utilizadas para fazer inferências estatísticas sobre a população (HAIR JR. ET AL., 2005); e (5) as hipóteses da pesquisa também serão testadas com o emprego de regressões quantílicas.

\footnotetext{
${ }^{58}$ Na metodologia proposta por Dechow, Sloan e Sweeney (1995), os coeficientes estimados por meio do modelo Jones são utilizados para a estimação das $A N D_{i t}$, onde $\Delta R_{i t}$ é substituído por $\Delta R_{i t}-\Delta R e c e b_{i t}$. As $E S C$ são calculadas pela diferença entre as $A T_{i t}$ e as $A N D_{i t}$ estimadas.
} 


\subsection{Mensuração das Ajustes Tributários Anormais (DCTA)}

De acordo com o exposto na seção 4.5.2.2, a proxy para utilizada mensurar os ajustes tributários anormais foi a DCTA, obtida por meio da equação (38). Nesse modelo, foram consideradas variáveis capazes, pelo menos teoricamente, de oferecer alguma explicação para as $D C T$, considerando algumas características da apuração do IRPJ e da CSLL, definidas na legislação tributária. As estatísticas descritivas dessas variáveis são apresentadas na Tabela 8.

Tabela 8 - Estatísticas Descritivas - Variáveis da equação (38)

Painel A - Amostra total

\begin{tabular}{lccccccc}
\hline \multicolumn{1}{c}{ Variáveis } & Média & $\begin{array}{c}\text { Desvio } \\
\text { Padrão }\end{array}$ & Mínimo & Q05 & Q50 & Q95 & Máximo \\
\hline DCT & 0,037 & 0,081 & $-0,418$ & $-0,033$ & 0,020 & 0,169 & 0,948 \\
$\Delta R$ & 0,038 & 0,274 & $-4,917$ & $-0,139$ & 0,009 & 0,277 & 3,440 \\
Imob & 0,284 & 0,952 & 0,000 & 0,000 & 0,145 & 0,811 & 2,494 \\
Invest & 0,184 & 0,274 & 0,000 & 0,000 & 0,040 & 0,824 & 176,167 \\
PJF10 & 2,311 & 0,276 & 0,000 & 0,000 & 1,000 & 9,000 & 10,000 \\
AFD & 0,018 & 0,035 & 0,000 & 0,000 & 0,002 & 0,085 & 0,275 \\
PJF10 x AFD & 0,050 & 0,183 & 0,000 & 0,000 & 0,000 & 0,267 & 1,975 \\
ATEF & 0,1678 & 0,4292 & 0,0000 & 0,0000 & 0,0816 & 0,4143 & 9,2272 \\
\hline
\end{tabular}

Painel B - Setor 1: Indústria

\begin{tabular}{lccccccc}
\hline \multicolumn{1}{c}{ Variáveis } & Média & $\begin{array}{c}\text { Desvio } \\
\text { Padrão }\end{array}$ & Mínimo & Q05 & Q50 & Q95 & Máximo \\
\hline DCT & 0,028 & 0,066 & $-0,418$ & $-0,029$ & 0,017 & 0,148 & 0,318 \\
$\Delta R$ & 0,029 & 0,393 & $-4,917$ & $-0,241$ & 0,017 & 0,332 & 3,440 \\
Imob & 0,399 & 1,442 & 0,000 & 0,039 & 0,273 & 0,718 & 2,494 \\
Invest & 0,152 & 0,182 & 0,000 & 0,000 & 0,081 & 0,538 & 0,982 \\
PJF10 & 2,735 & 2,869 & 0,000 & 0,000 & 2,000 & 9,000 & 10,000 \\
AFD & 0,021 & 0,040 & 0,000 & 0,000 & 0,008 & 0,098 & 0,275 \\
PJF10 x AFD & 0,080 & 0,263 & 0,000 & 0,000 & 0,000 & 0,347 & 1,975 \\
ATEF & 0,1260 & 0,3117 & 0,0000 & 0,0000 & 0,0408 & 0,3631 & 4,6410 \\
\hline
\end{tabular}

Painel C - Setor 2: Comércio

\begin{tabular}{lccccccc}
\hline \multicolumn{1}{c}{ Variáveis } & Média & $\begin{array}{c}\text { Desvio } \\
\text { Padrão }\end{array}$ & Mínimo & Q05 & Q50 & Q95 & Máximo \\
\hline DCT & 0,038 & 0,092 & $-0,149$ & $-0,018$ & 0,029 & 0,116 & 0,63 \\
$\Delta R$ & 0,156 & 0,364 & $-0,418$ & $-0,101$ & 0,09 & 0,871 & 2,051 \\
Imob & 0,140 & 0,117 & 0,000 & 0,000 & 0,123 & 0,328 & 0,476 \\
Invest & 0,162 & 0,257 & 0,000 & 0,000 & 0,049 & 0,456 & 1,582 \\
PJF10 & 1,107 & 2,221 & 0,000 & 0,000 & 0,000 & 8,000 & 9,000 \\
AFD & 0,015 & 0,02 & 0,000 & 0,000 & 0,007 & 0,064 & 0,084 \\
PJF10 x AFD & 0,014 & 0,051 & 0,000 & 0,000 & 0,000 & 0,077 & 0,337 \\
ATEF & 0,1677 & 0,1333 & 0,0000 & 0,0000 & 0,2261 & 0,3383 & 0,3460 \\
\hline
\end{tabular}


Tabela 8 - Estatísticas Descritivas - Variáveis da equação (38)

Painel D - Setor 3: Construção Civil

\begin{tabular}{lccccccc}
\hline \multicolumn{1}{c}{ Variáveis } & Média & $\begin{array}{c}\text { Desvio } \\
\text { Padrão }\end{array}$ & Mínimo & Q05 & Q50 & Q95 & Máximo \\
\hline DCT & 0,086 & 0,107 & $-0,056$ & 0,000 & 0,058 & 0,25 & 0,659 \\
$\Delta R$ & 0,015 & 0,069 & $-0,084$ & $-0,041$ & 0,000 & 0,199 & 0,39 \\
Imob & 0,039 & 0,119 & 0,000 & 0,001 & 0,005 & 0,185 & 0,903 \\
Invest & 0,618 & 0,272 & 0,000 & 0,263 & 0,565 & 1,069 & 1,247 \\
PJF10 & 1,768 & 2,276 & 0,000 & 0,000 & 0,000 & 6,000 & 8,000 \\
AFD & 0,006 & 0,027 & 0,000 & 0,000 & 0,000 & 0,023 & 0,214 \\
PJF10 x AFD & 0,027 & 0,18 & 0,000 & 0,000 & 0,000 & 0,077 & 1,495 \\
ATEF & 0,0127 & 0,0411 & 0,0000 & 0,0000 & 0,0000 & 0,0701 & 0,2474 \\
\hline
\end{tabular}

Painel E - Setor 4: Serviços de Comunicação, Água e Energia

\begin{tabular}{lccccccc}
\hline \multicolumn{1}{c}{ Variáveis } & Média & $\begin{array}{c}\text { Desvio } \\
\text { Padrão }\end{array}$ & Mínimo & Q05 & Q50 & Q95 & Máximo \\
\hline DCT & 0,035 & 0,057 & $-0,092$ & $-0,032$ & 0,021 & 0,161 & 0,268 \\
$\Delta R$ & 0,003 & 0,074 & $-0,589$ & $-0,067$ & 0,000 & 0,121 & 0,165 \\
Imob & 0,228 & 0,312 & 0,000 & 0,000 & 0,025 & 0,83 & 1,316 \\
Invest & 0,108 & 0,232 & 0,000 & 0,000 & 0,000 & 0,804 & 0,97 \\
PJF10 & 1,586 & 1,775 & 0,000 & 0,000 & 1,000 & 5,000 & 8,000 \\
AFD & 0,024 & 0,041 & 0,000 & 0,000 & 0,006 & 0,092 & 0,237 \\
PJF10 x AFD & 0,043 & 0,117 & 0,000 & 0,000 & 0,000 & 0,271 & 0,77 \\
ATEF & 0,2618 & 0,3944 & 0,0000 & 0,0000 & 0,2389 & 0,7008 & 3,9514 \\
\hline
\end{tabular}

Painel F - Setor 5: Transportes e serviços relacionados

\begin{tabular}{lccccccc}
\hline \multicolumn{1}{c}{ Variáveis } & Média & $\begin{array}{c}\text { Desvio } \\
\text { Padrão }\end{array}$ & Mínimo & Q05 & Q50 & Q95 & Máximo \\
\hline DCT & 0,021 & 0,062 & $-0,088$ & $-0,039$ & 0,003 & 0,128 & 0,309 \\
$\Delta R$ & 0,062 & 0,104 & $-0,082$ & $-0,035$ & 0,027 & 0,246 & 0,506 \\
Imob & 0,235 & 0,320 & 0,000 & 0,000 & 0,038 & 0,811 & 1,237 \\
Invest & 0,052 & 0,150 & 0,000 & 0,000 & 0,000 & 0,301 & 0,825 \\
PJF10 & 2,169 & 2,803 & 0,000 & 0,000 & 1,000 & 8,000 & 10,000 \\
AFD & 0,022 & 0,032 & 0,000 & 0,000 & 0,006 & 0,089 & 0,196 \\
PJF10 x AFD & 0,051 & 0,126 & 0,000 & 0,000 & 0,000 & 0,339 & 0,593 \\
ATEF & 0,2813 & 0,7998 & 0,0000 & 0,0000 & 0,2063 & 0,5643 & 9,2272 \\
\hline
\end{tabular}

Painel G - Setor 6: Outros

\begin{tabular}{lccccccc}
\hline \multicolumn{1}{c}{ Variáveis } & Média & $\begin{array}{c}\text { Desvio } \\
\text { Padrão }\end{array}$ & Mínimo & Q05 & Q50 & Q95 & Máximo \\
\hline DCT & 0,051 & 0,113 & $-0,35$ & $-0,055$ & 0,036 & 0,18 & 0,948 \\
$\Delta R$ & 0,031 & 0,207 & $-0,574$ & $-0,148$ & 0,005 & 0,282 & 1,348 \\
Imob & 0,322 & 0,855 & 0,000 & 0,000 & 0,090 & 0,863 & 9,529 \\
Invest & 0,262 & 0,350 & 0,000 & 0,000 & 0,100 & 0,946 & 1,762 \\
PJF10 & 3,029 & 3,309 & 0,000 & 0,000 & 2,000 & 9,000 & 10,000 \\
AFD & 0,011 & 0,027 & 0,000 & 0,000 & 0,000 & 0,086 & 0,148 \\
PJF10 x AFD & 0,013 & 0,048 & 0,000 & 0,000 & 0,000 & 0,086 & 0,440 \\
ATEF & 0,1135 & 0,1730 & 0,0000 & 0,0000 & 0,0302 & 0,3451 & 1,0000 \\
\hline
\end{tabular}


$\boldsymbol{D C T}$ representa as diferenças contábil-tributárias totais do ano $t ; \boldsymbol{\Delta R}$ é a variação das receitas líquidas anuais do ano $t-1$ para o ano $t$; Imob é o somatório dos saldos finais brutos, do ano $t$, do ativo imobilizado e do ativo diferido; Invest é saldo final do ano $t$ dos investimentos avaliados pelo método da equivalência patrimonial; PJF10 indica o número de anos em que $L A I R<0$, considerando os últimos 10 anos, onde LAIR é o lucro antes da tributação; $\boldsymbol{A F D}$ é o saldo final do ano $t$ do ativo fiscal diferido; e $\boldsymbol{A T E F}$ representa a alíquota de tributação efetiva, a qual é calculada pela divisão da soma entre o IRPJ e a CSLL correntes pelo LAIR. Somente foram consideradas as observações em que $A T E F \geq 0$. Essas variáveis, exceto $P J F 10$ e $A T E F$, são escalonadas pelo ativo total do ano $t$ -

1. As regressões foram estimadas com erros padrão robustos. Número de observações (para $A T E F$ ):

(i) Amostra total - 847 (781); (ii) setor 1 - 302 (270); (iii) setor 2 - 56 (51); (iv) setor 3 - 69 (64);

(v) setor 4 - 140 (133); (vi) setor 5 - 142 (137); e (vii) setor 6 - 138 (126).

Fonte: dados da pesquisa

É possível verificar que, tanto na amostra total quanto no nível setorial, as firmas apresentam $D C T$ média $>0$. Entre os setores, a proporção de observações onde $D C T>0$ varia entre $54,22 \%$ (setor 5) e 76,78\% (setor 2). Essas estatísticas indicam que, na média, o lucro tributável se mostrou inferior ao lucro contábil e que essa configuração foi predominante entre as firmas. Nesse ponto, é importante lembrar que parte dessa diferença pode decorrer dos ajustes específicos do RTT. A alíquota de tributação efetiva (ATEF) média enfrentada pelas firmas foi de, aproximadamente, $16,78 \%$, carga tributária bem inferior à nominal, que é de $34 \%$.

O setor que exibe o maior nível de DCT $(0,086)$ é o setor 3 (construção civil), o que, até certo ponto, é algo esperado, tendo em vista que a apuração do lucro tributável nesse setor é fortemente influenciada pelo regime de caixa. É possível que parte dessas $D C T$ seja atribuída às diferenças decorrentes dos resultados da equivalência patrimonial, uma vez que esse setor também apresenta o maior nível de investimentos avaliados por esse método. A tributação efetiva média do setor 3 também foi a mais baixa entre os setores: 1,27\%. Neste caso, é importante lembrar que, desde 2004, o setor de construção civil, especificamente o segmento de incorporação imobiliária, goza dos benefícios advindos do Regime Especial de Tributação do Patrimônio de Afetação (RET) ${ }^{59}$, onde as alíquotas do IRPJ e da CSLL têm variado ao longo do tempo entre $0,31 \%$ e $2,2 \%$; e $0,16 \%$ e $1,15 \%$, respectivamente, conforme a natureza do empreendimento imobiliário ${ }^{60}$.

Em média, entre os anos de 2000 e 2012, as firmas apresentaram $L A I R<0$ em 2 anos (2,311 anos). As maiores frequências médias são observadas no setor 5, com 3,029 anos, e no setor 1, com 2,735 anos. Das 234 firmas analisadas, $114(49,11 \%)$ apresentam PJF10 2 para o período analisado, sendo que destas, em $60(25,89 \%)$ PJF10 = 0 . Considerando a amostra

\footnotetext{
${ }^{59}$ O RET foi instituído pela Lei $n^{\circ} 10.931 / 2004$.

${ }^{60}$ Os empreendimentos imobiliários no âmbito do Programa Minha Casa Minha Vida gozam das menores alíquotas: $0,31 \%(I R P J)$ e $0,16 \%$ (CSLL).
} 
total (firma-ano), em 556 observações $(65,64 \%)$ verifica-se $P J F 10 \leq 2$ em pelo menos um dos anos analisados, onde $315(37,19 \%)$ correspondem a $P J F 10=0$. Essa distribuição sinaliza que a maioria das firmas pode não possuir saldo de prejuízo fiscal para algum dos anos analisados.

Verifica-se que, de uma maneira geral, o $A F D$ apresentou níveis muito baixos, sugerindo, assim, que os ajustes temporários positivos (adições temporárias) para a apuração do lucro tributável, bem como as respectivas reversões, seriam pouco representativos. Aliada às indicações obtidas com base na distribuição de PJF10, essa constatação aponta que, na média, as firmas podem apresentar saldos de prejuízo fiscal relativamente baixos. Essa configuração sinaliza a possibilidade de compensação integral dos prejuízos nos períodos em que são apurados, na hipótese em que existam adições permanentes, tais como, resultados negativos da equivalência patrimonial, ou na hipótese de adições referentes à reversão de passivos fiscais diferidos, por exemplo. No entanto, essa avaliação requer cautela, haja vista a limitação informacional das estatísticas consideradas.

Outro aspecto que merece comentários é o fato de que nenhuma das variáveis constantes na Tabela 8 possui distribuição normal. Os resultados do teste de Doornik-Hansen rejeitaram essa hipótese a um nível de significância $1 \%$.

A Tabela 9 apresenta as matrizes de correlação entre as variáveis ora analisadas, tanto em relação à amostra total quanto em relação aos setores considerados. São empregadas as correlações de Pearson (paramétrica) e de Spearman (não paramétrica). Esta última, em razão das variáveis não possuírem distribuição normal.

Tabela 9 - Matrizes de Correlação - Pearson (parte inferior) e Spearman (parte superior)

Painel A - Amostra Total

\begin{tabular}{|c|c|c|c|c|c|c|c|c|c|}
\hline & & $D C T$ & $\Delta R$ & Imob & Invest & PJF10 & $A F D$ & $\begin{array}{l}\text { PJF10 } x \\
A F D\end{array}$ & $A T E F$ \\
\hline$D C T$ & & 1,000 & $\underset{\substack{* *\\
}}{0,075}$ & $-\underset{* *}{* 0,105}$ & $0, \underset{* * *}{* * 4}$ & $-\underset{* * * * *}{ }-0,364$ & 0,015 & $-\underset{* * *}{-0,114}$ & $\underset{\substack{* * * *\\
}}{-0,102}$ \\
\hline$\Delta R$ & & $\underset{* *}{0,070}$ & 1,000 & 0,302 & $\begin{array}{c}-0,062 \\
*\end{array}$ & $\underset{* *}{-0,069}$ & $\underset{* * * *}{0,154}$ & $\underset{* *}{0,082}$ & $\underset{* * * *}{0,177}$ \\
\hline Imob & & $-0,061^{*}$ & 0,014 & 1,000 & $-\underset{* * *}{-0,120}$ & 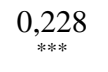 & $\underset{* *}{0,077}$ & $\underset{* * * *}{0,129}$ & $\underset{* * * *}{-0,093}$ \\
\hline Invest & & $\underset{* * * *}{0,407}$ & $-0,027$ & $-\underset{* * * *}{0,113}$ & 1,000 & $-\underset{* * *}{-0,162}$ & $-0,054$ & $\underset{*}{-0,061}$ & $-\underset{* * *}{-0,272}$ \\
\hline PJF10 & & $-0,155$ & $-0,011$ & $\underset{* * * *}{0,197}$ & $-\underset{* * *}{-0,163}$ & 1,000 & $-\underset{*}{-0,061}$ & $\underset{* * * *}{0,394}$ & $\underset{* * *}{-0,353}$ \\
\hline$A F D$ & & $-0,003$ & 0,047 & $-0,015$ & 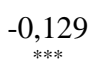 & $\underset{* *}{0,072}$ & 1,000 & $\underset{\substack{* * * * \\
\text { (2) }}}{0,693}$ & $\underset{* * * *}{0,196}$ \\
\hline $\begin{array}{l}\text { PJF10 } \\
\text { AFD }\end{array}$ & $x$ & 0,025 & 0,023 & 0,026 & $\underset{*}{-0,067}$ & 0,311 & 0,767 & 1,000 & $-0,025$ \\
\hline$A T E F$ & & $-0,137$ & 0,007 & $-0,038$ & $-\underset{* * *}{-0,160}$ & $-\underset{* * *}{* 0,096}$ & 0,004 & $-0,052$ & 1,000 \\
\hline
\end{tabular}


Tabela 9 - Matrizes de Correlação - Pearson (parte inferior) e Spearman (parte superior)

Painel B - Setor 1: Indústria

\begin{tabular}{|c|c|c|c|c|c|c|c|c|}
\hline & $D C T$ & $\Delta R$ & Imob & Invest & PJF10 & $A F D$ & $\begin{array}{c}\text { PJF10 } x \\
\text { AFD }\end{array}$ & $A T E F$ \\
\hline$D C T$ & 1,000 & $\underset{* * * *}{0,244}$ & $-0,140$ & $\underset{\substack{* * * * \\
0}}{0,253}$ & $\underset{\substack{* * * \\
\text { (2) }}}{-0,449}$ & 0,087 & $-0,197$ & $\underset{\substack{* * * * \\
0}}{0,250}$ \\
\hline$\Delta R$ & 0,076 & 1,000 & $\underset{\substack{* * * \\
*}}{0,122}$ & 0,007 & $\underset{*}{-0,098}$ & $0, \underset{* * *}{0,206}$ & 0,158 & $\underset{\substack{* * * * \\
*}}{0,183}$ \\
\hline Imob & $-0,042$ & 0,005 & 1,000 & $-\underset{* * *}{-0,415}$ & 0,250 & $-0,035$ & 0,122 & $\underset{* * *}{-0,124}$ \\
\hline Invest & $\underset{* * *}{0,126}$ & $-0,013$ & $\begin{array}{c}-0,099 \\
*\end{array}$ & 1,000 & $-\underset{* * *}{-0,288}$ & 0,037 & $-0,149$ & $\underset{*}{0,104}$ \\
\hline PJF10 & $-0,0,302$ & $-0,054$ & $\underset{\substack{* * * * \\
0,168}}{0}$ & $-\underset{* * * *}{0,194}$ & 1,000 & $-0,025$ & $\underset{* * * *}{0,368}$ & $-\underset{* * * *}{-0,440}$ \\
\hline$A F D$ & 0,000 & 0,059 & $-0,021$ & $-0,086$ & $\underset{\substack{* * * * \\
0,188}}{ }$ & 1,000 & $\underset{\substack{* * * \\
0,780}}{0}$ & $-0,018$ \\
\hline $\begin{array}{l}\text { PJF10 } x \\
A F D\end{array}$ & $-0,054$ & 0,036 & 0,000 & $\underset{* *}{-0,115}$ & $\underset{\substack{* * * * \\
*}}{0,371}$ & $0, \underset{* * * *}{* * *}$ & 1,000 & $-{ }_{* * *}-162$ \\
\hline$A T E F$ & $-\underset{* * *}{-0,049}$ & 0,009 & $-0,041$ & $-0,073$ & $\underset{* *}{-0,139}$ & $-0,081$ & $-0,093$ & 1,000 \\
\hline
\end{tabular}

Painel C - Setor 2: Comércio

\begin{tabular}{|c|c|c|c|c|c|c|c|c|}
\hline & $D C T$ & $\Delta R$ & Imob & Invest & PJF10 & $A F D$ & $\begin{array}{c}\text { PJF10 } x \\
A F D\end{array}$ & ATEF \\
\hline$D C T$ & 1,000 & $-0,169$ & $\begin{array}{c}-0,343 \\
* * * * \\
* 3\end{array}$ & 0,191 & $-0,070$ & 0,061 & $-0,180$ & $-0,203$ \\
\hline$\Delta R$ & $-0,257^{*}$ & 1,000 & 0,130 & $-0,082$ & $-0,034$ & 0,023 & 0,134 & 0,188 \\
\hline Imob & $-0,007$ & $-0,089$ & 1,000 & $\underset{\substack{0,34 * \\
* * *}}{0,346}$ & $\underset{* *}{-0,314}$ & $\underset{* *}{0,322}$ & 0,047 & $-0,063$ \\
\hline Invest & $-0,078$ & 0,022 & 0,195 & 1,000 & 0,061 & $\underset{* * *}{0,301}$ & 0,165 & 0,141 \\
\hline PJF10 & 0,348 & 0,101 & $-0,361^{* * * *}$ & $-0,094$ & 1,000 & 0,012 & $\underset{* * * *}{0,638}$ & $-0,291$ \\
\hline$A F D$ & $-0,119$ & 0,138 & $-0,005$ & $-0,022$ & $-0,045$ & 1,000 & $\underset{* * * *}{0,459}$ & $-0,095$ \\
\hline $\begin{array}{l}\text { PJF10 } x \\
\text { AFD }\end{array}$ & $-0,106$ & $\underset{* * * * *}{0,413}$ & $-0,073$ & 0,011 & 0,197 & $\underset{* * * *}{0,700}$ & 1,000 & $-0,117$ \\
\hline ATEF & $\underset{* * * *}{-0,242}$ & 0,092 & 0,069 & 0,084 & $-0,316$ & $-0,145$ & $-0,109$ & 1,000 \\
\hline
\end{tabular}

Painel D - Setor 3: Construção Civil

\begin{tabular}{|c|c|c|c|c|c|c|c|c|c|}
\hline & & $D C T$ & $\Delta R$ & Imob & Invest & PJF10 & $A F D$ & $\begin{array}{c}\text { PJF10 } x \\
\text { AFD }\end{array}$ & $A T E F$ \\
\hline$D C T$ & & 1,000 & 0,196 & $0, \underset{* *}{0,238}$ & $\underset{\substack{0,533 \\
* * * *}}{0,5}$ & $-\underset{* * * *}{-0,339}$ & 0,249 & 0,193 & 0,100 \\
\hline$\Delta R$ & & 0,104 & 1,000 & 0,116 & 0,123 & 0,131 & 0,130 & 0,119 & 0,026 \\
\hline Imob & & 0,019 & 0,015 & 1,000 & $-0,118$ & 0,038 & 0,079 & 0,082 & 0,129 \\
\hline Invest & & 0,441 & 0,062 & $-0,311$ & 1,000 & $-\underset{* * * *}{*, 341}$ & $-0,082$ & $-0,020$ & $\underset{*}{-0,208}$ \\
\hline PJF10 & & 0,069 & 0,158 & 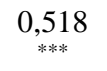 & $\underset{* * * *}{-0,323}$ & 1,000 & $\underset{*}{0,229}$ & $\underset{* * *}{0,411}$ & 0,202 \\
\hline$A F D$ & & $\underset{* * * *}{0,608}$ & $-0,172$ & $-0,033$ & 0,024 & $\underset{* *}{0,294}$ & 1,000 & $0, \underset{* * * *}{* * *}$ & $\underset{* * *}{0,472}$ \\
\hline $\begin{array}{l}\text { PJF10 } \\
A F D\end{array}$ & $x$ & 0,659 & $-0,170$ & $-0,022$ & 0,029 & $\underset{* *}{0,308}$ & 0,971 & 1,000 & 0,462 \\
\hline$A T E F$ & & $-0,046$ & $-0,003$ & $\underset{* * * *}{0,490}$ & $\underset{*}{-0,208}$ & $\begin{array}{c}0,240 \\
*\end{array}$ & 0,249 & 0,105 & 1,000 \\
\hline
\end{tabular}


Tabela 9 - Matrizes de Correlação - Pearson (parte inferior) e Spearman (parte superior)

Painel E - Setor 4: Serviços de Comunicação, Água e Energia

\begin{tabular}{|c|c|c|c|c|c|c|c|c|c|}
\hline & & $D C T$ & $\Delta R$ & Imob & Invest & PJF10 & $A F D$ & $\begin{array}{c}\text { PJF10 } x \\
A F D\end{array}$ & $A T E F$ \\
\hline$D C T$ & & 1,000 & $-0,126$ & 0,002 & $\underset{* * * *}{0,359}$ & $-0,326$ & 0,095 & 0,020 & $\underset{\substack{* * * * \\
* * 0,545}}{-0,5}$ \\
\hline$\Delta R$ & & $-0,003$ & 1,000 & $-0,081$ & $-0,083$ & 0,105 & $-0,098$ & 0,031 & 0,125 \\
\hline Imob & & $-0,006$ & $-0,012$ & 1,000 & $\underset{\substack{* * * \\
0}}{0,217}$ & $-0,026$ & $-0,020$ & 0,002 & 0,141 \\
\hline Invest & & $\underset{* * * *}{0,635}$ & $-0,070$ & $-0,055$ & 1,000 & $-0,158$ & 0,063 & 0,089 & $\begin{array}{c}-0,145 \\
*\end{array}$ \\
\hline PJF10 & & $-\underset{* * *}{-0,255}$ & 0,076 & $-0,157$ & $-0,075$ & 1,000 & $-0,059$ & $\underset{* * * *}{0,412}$ & $-0,096$ \\
\hline$A F D$ & & 0,005 & $-0,012$ & $-0,150$ & 0,023 & 0,077 & 1,000 & $\underset{* * * *}{0,701}$ & 0,034 \\
\hline $\begin{array}{l}\text { PJF10 } \\
A F D\end{array}$ & $x$ & 0,022 & $-0,042$ & $-0,020$ & 0,111 & 0,367 & $\underset{\substack{* * * * \\
*}}{0,737}$ & 1,000 & $-0,031$ \\
\hline$A T E F$ & & $-\underset{\substack{* \\
* * *}}{0,359}$ & 0,038 & $-0,025$ & $\underset{* *}{-0,201}$ & 0,140 & $-0,046$ & $-0,093$ & $\mathbf{1 , 0 0 0}$ \\
\hline
\end{tabular}

Painel F - Setor 5: Transportes e serviços relacionados

\begin{tabular}{|c|c|c|c|c|c|c|c|c|c|}
\hline & & $D C T$ & $\Delta R$ & Imob & Invest & PJF10 & $A F D$ & $\begin{array}{c}\text { PJF10 } x \\
\text { AFD }\end{array}$ & $A T E F$ \\
\hline$D C T$ & & 1,000 & $-0,036$ & $\underset{* * * *}{0,259}$ & $0, \underset{\substack{* \\
* * *}}{0,474}$ & $-\underset{* * * *}{-0,238}$ & $-0,217$ & $-0,130$ & $\underset{\substack{*, 3 * * \\
* * *}}{-0,349}$ \\
\hline$\Delta R$ & & $-0,118$ & 1,000 & $-\underset{* * *}{-0,216}$ & $-0,014$ & $-0,138$ & 0,068 & $-0,030$ & $\underset{* * *}{0,270}$ \\
\hline Imob & & 0,004 & $\underset{* * *}{-0,263}$ & 1,000 & $\underset{* * * *}{0,325}$ & $\underset{* * *}{0,287}$ & $-0,018$ & 0,134 & $\underset{* * *}{-0,549}$ \\
\hline Invest & & $\underset{* * * *}{0,826}$ & $-0,079$ & $-0,055$ & 1,000 & $-0,007$ & $\underset{* *}{0,206}$ & $0, \underset{* * *}{* * 249}$ & $\underset{* * * *}{-0,288}$ \\
\hline PJF10 & & $\underset{* *}{-0,177}$ & $\underset{* *}{-0,198}$ & $\underset{* * *}{0,495}$ & $-\underset{* *}{0,185}$ & 1,000 & 0,026 & $\underset{* * *}{0,570}$ & $\underset{* * * *}{-0,470}$ \\
\hline$A F D$ & & $-0,212$ & 0,039 & 0,147 & $-0,101$ & 0,044 & 1,000 & $0,0,589$ & $\underset{* * * *}{0,221}$ \\
\hline $\begin{array}{l}\text { PJF10 } \\
A F D\end{array}$ & $x$ & $-0,052$ & $-0,075$ & $\underset{* * *}{0,390}$ & $-0,083$ & $\underset{\substack{* * * * \\
* *}}{0,387}$ & $\underset{\substack{* * *\\
}}{0,701}$ & 1,000 & $-0,124$ \\
\hline$A T E F$ & & $-0,124$ & $-0,014$ & $-0,160$ & $-0,082$ & $-0,131$ & 0,009 & $-0,049$ & 1,000 \\
\hline
\end{tabular}

Painel G - Setor 6: Outros

\begin{tabular}{|c|c|c|c|c|c|c|c|c|c|}
\hline & & $D C T$ & $\Delta R$ & Imob & Invest & PJF10 & $A F D$ & $\begin{array}{c}\text { PJF10x } \\
\text { AFD }\end{array}$ & $A T E F$ \\
\hline$D C T$ & & 1,000 & 0,131 & $\underset{\substack{* * * \\
-0,465}}{-}$ & $\underset{* * * *}{0,591}$ & 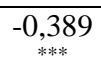 & $\underset{\substack{* * * \\
0,229}}{0}$ & 0,066 & $-0,520$ \\
\hline$\Delta R$ & & 0,424 & 1,000 & $\underset{*}{0,148}$ & 0,005 & $-0,032$ & 0,218 & $-0,071$ & 0,156 \\
\hline Imob & & $-0,139$ & 0,185 & 1,000 & $-0,484$ & 0,324 & 0,095 & 0,030 & 0,033 \\
\hline Invest & & $\underset{* * *}{0,399}$ & -0.040 & -0.229 & 1,000 & $-0,287$ & 0,013 & $-0,026$ & $-\underset{* *}{-0,199}$ \\
\hline PJF10 & & $\underset{*}{-0,156}$ & $0, \underset{* *}{0,188}$ & $\underset{* * * *}{0,333}$ & $-0,260$ & 1,000 & $-0,318$ & 0,192 & $-\underset{* * * *}{-0,417}$ \\
\hline$A F D$ & & 0,029 & 0,095 & $-0,083$ & $-\underset{* *}{-0,169}$ & $-0,216$ & 1,000 & 0,617 & $\underset{* * *}{0,424}$ \\
\hline $\begin{array}{l}\text { PJF10 } \\
\text { AFD }\end{array}$ & $x$ & 0,041 & 0,003 & 0,016 & $-0,086$ & $\underset{* *}{0,211}$ & $\underset{* * * *}{0,311}$ & 1,000 & 0,130 \\
\hline$A T E F$ & & $-\underset{* *}{0,195}$ & $-0,023$ & $-0,061$ & $-\underset{* * * *}{0,316}$ & $-0,138$ & 0,201 & 0,086 & $\mathbf{1 , 0 0 0}$ \\
\hline
\end{tabular}


$\boldsymbol{D C T}$ representa as diferenças contábil-tributárias totais do ano $t ; \boldsymbol{\Delta R}$ é a variação das receitas líquidas anuais do ano $t$ - 1 para o ano $t$; Imob é o somatório dos saldos finais brutos, do ano $t$, do ativo imobilizado e do ativo diferido; Invest é saldo final do ano $t$ dos investimentos avaliados pelo método da equivalência patrimonial; PJF10 indica o número de anos em que $L A I R<0$, considerando os últimos 10 anos, onde $L A I R$ é o lucro antes da tributação; $\boldsymbol{A F D}$ é o saldo final do ano $t$ do ativo fiscal diferido; e $\boldsymbol{A T E F}$ representa a alíquota de tributação efetiva, a qual é calculada pela divisão da soma entre o IRPJ e a CSLL correntes pelo LAIR. Somente foram consideradas as observações em que ATEF $>0$. Essas variáveis, exceto $P J F 10$ e $A T E F$, são escalonadas pelo ativo total do ano $t-1$. *, ** e *** indicam a significância estatística a $10 \%, 5 \%$; e $1 \%$, respectivamente.

Fonte: dados da pesquisa.

A análise das correlações evidencia ainda mais as diferenças setoriais, parcialmente observadas na distribuição das variáveis, e revela aspectos interessantes. Por exemplo, a ausência de correlação significativa entre $\triangle R$ e $D C T$, observada na maioria dos setores; bem como a ausência de correlação significativa entre Imob e DCT nos setores 1 e 4, os quais, tradicionalmente, apresentam maior intensividade de capital e gozam de diversos benefícios relacionados à depreciação acelerada incentivada para fins do IRPJ e da $C S L L^{61}$.

Outrossim, observa-se que, exceto para o setor 2, há uma correlação positiva e significativa entre Invest e $D C T$, comportamento linear já esperado, em razão do tratamento tributário que é conferido para os resultados advindos daqueles investimentos.

PJF10 é, na maioria dos setores, negativamente correlacionado com DCT e com ATEF, enquanto PJF10 x AFD somente apresentou correlação significativa no setor 1. Esses resultados reforçam, mesmo que precariamente, a indicação preliminar de que a maioria das firmas da amostra pode apresentar saldo de prejuízo fiscal pouco representativo.

No que se refere à determinação das DCTA, a Tabela 10 apresenta os resultados das estimações das DCT normais realizadas para cada um dos setores analisados. As DCTA são representadas pelos resíduos dessas estimações.

\footnotetext{
${ }^{61}$ Além da depreciação acelerada incentivada prevista no art. 313 do Decreto $n^{0}$ 3.000/1999 (Regulamento do Importo de Renda - RIR99), são exemplos os benefícios concedidos pela Lei $\mathrm{n}^{\circ}$ 11.774/2008, aos fabricantes de veículos e autopeças e aos fabricantes de bens de capital, os quais permitem a depreciação acelerada para máquinas, equipamentos, aparelhos e instrumentos novos, adquiridos entre 1\%/5/2008 e 31/12/2010. Outro exemplo é o incentivo dado às concessionárias, permissionárias e autorizadas de geração de energia elétrica, por meio do qual essas firmas podem deduzir a parcela da depreciação regulatória que excede o limite fixado pela RFB, conforme a Lei $\mathrm{n}^{\circ} 11.196 / 2005$.
} 
Tabela 10 - Estimações setoriais das $D C T$ normais - equação (38)

\begin{tabular}{|c|c|c|c|c|c|c|c|}
\hline & \multirow{2}{*}{$\begin{array}{c}\text { Sinal } \\
\text { Previsto }\end{array}$} & \multicolumn{6}{|c|}{ Setores } \\
\hline & & 1 & 2 & 3 & 4 & 5 & 6 \\
\hline Const & $?$ & $0,049^{* * * *}$ & 0,015 & 0,007 & $0,041^{* * *}$ & $0,017^{* *}$ & 0,031 \\
\hline$\Delta R$ & $?$ & 0,007 & $-0,059^{* *}$ & $0,308^{* *}$ & 0,026 & $-0,022$ & $0,265^{*}$ \\
\hline Imob & - & 0,000 & $0,099^{* *}$ & $0,222^{* * *}$ & $-0,005$ & 0,010 & $-0,013$ \\
\hline Invest & + & 0,028 & $-0,013$ & $0,159^{* * *}$ & $0,150^{* * *}$ & $0,323^{* * *}$ & $0,117^{* * *}$ \\
\hline PJF10 & $?$ & $-0,007^{* * *}$ & 0,018 & $-0,009^{* *}$ & $-0,008^{* * *}$ & $-0,003^{* * *}$ & $-0,005^{* * *}$ \\
\hline$A F D$ & + & 0,038 & $-0,063$ & $-2,061^{* * *}$ & $-0,086$ & $-0,643^{* * *}$ & $-0,151$ \\
\hline PJF10 $x A F D$ & + & 0,010 & $-0,244$ & $0,743^{* * *}$ & 0,036 & $0,140^{* * *}$ & $0,269^{* * * *}$ \\
\hline$d 2011$ & $?$ & $-0,010$ & $-0,010$ & $-0,040^{*}$ & $-0,004$ & 0,006 & 0,006 \\
\hline$d 2012$ & $?$ & $-0,007$ & $-0,012$ & $-0,030$ & $-0,003$ & $-0,002$ & $-0,006$ \\
\hline$d 2013$ & $?$ & $-0,014$ & 0,039 & $-0,034^{*}$ & $-0,022^{* *}$ & $-0,001$ & $-0,006$ \\
\hline Estatística $F$ & & $7,478^{* * * *}$ & $2,231^{* *}$ & $471,051^{* * *}$ & $13,727^{* * *}$ & $25,705^{* * *}$ & $8,706^{* * *}$ \\
\hline$R^{2}$ ajustado & & 0,0828 & 0,1312 & 0,6921 & 0,4375 & 0,7239 & 0,3520 \\
\hline $\begin{array}{l}\text { Normalidade } \\
\text { (Doornik-Hansen) }\end{array}$ & & $265,609^{* * *}$ & $35,426^{* * *}$ & 1,472 & $15,470^{* * *}$ & $26,669^{* * *}$ & $77,998^{* * *}$ \\
\hline $\begin{array}{l}\text { Autocorrelação } \\
\text { (Durbin-Watson) }\end{array}$ & & $\begin{array}{c}1,916 \\
\text { Sem } \\
\text { evidências }\end{array}$ & $\begin{array}{c}2,347 \\
\text { Inconclu } \\
\text { sivo }\end{array}$ & $\begin{array}{c}2,073 \\
\text { Sem } \\
\text { evidências }\end{array}$ & $\begin{array}{c}1,899 \\
\text { Sem } \\
\text { evidências }\end{array}$ & $\begin{array}{c}2,052 \\
\text { Sem } \\
\text { evidências }\end{array}$ & $\begin{array}{c}1,993 \\
\text { Sem } \\
\text { evidências }\end{array}$ \\
\hline Multicolinearidade & & $\mathrm{VIFs}<6,0$ & $\mathrm{VIFs}<3,0$ & $\begin{array}{c}\text { VIFs }< \\
19,0^{\dagger}\end{array}$ & $\mathrm{VIFs}<3,5$ & VIFs $<3,0$ & VIFs $<2,0$ \\
\hline Obs & & 302 & 56 & 69 & 140 & 142 & 138 \\
\hline
\end{tabular}

$\boldsymbol{D C T}$ representa as diferenças contábil-tributárias totais do ano $t ; \boldsymbol{\Delta R}$ é a variação das receitas líquidas anuais do ano $t-1$ para o ano $t$; Imob é o somatório dos saldos finais brutos, do ano $t$, do ativo imobilizado e do ativo diferido; Invest é saldo final do ano $t$ dos investimentos avaliados pelo método da equivalência patrimonial; $\boldsymbol{P J F 1 0}$ indica o número de anos em $L A I R<0$, onde $L A I R$ é o lucro antes do IRPJ e da CSLL; e $\boldsymbol{A F D}$ é o saldo final do ano $t$ do ativo fiscal diferido. Essas variáveis, exceto PJF10, são escalonadas pelo ativo total do ano $t-1$. As regressões foram estimadas pelos MQO com erros padrão robustos. (i) setor 1: Indústria; (ii) setor 2: Comércio; (iii) setor 3: Construção Civil; (iv) setor 4: Serviços de Comunicação, Água e Energia; (v) setor 5: Transportes e serviços relacionados; e (vi) setor 6: Outros. *, ** e *** indicam a significância estatística bicaudal a 10\%, 5\%; e 1\%, respectivamente. † A variável $A F D$ e a variável interativa PJF10 x AFD apresentaram VIF de 18,233 e 18,383, respectivamente. As demais apresentaram VIF inferior a 2,5.

Fonte: dados da pesquisa.

Para todos os setores, as estimações apresentam ajuste satisfatório. Em todas elas, foi rejeitada, a um nível de significância de 1\%, a hipótese de que os coeficientes, conjuntamente, são nulos. O poder explicativo evidenciado pelo $R^{2}$ ajustado varia consideravelmente entre setores, indo de 8,28\% (setor 1: Indústria) até 72,39\% (setor 5: Transportes e serviços relacionados).

É possível que o baixo poder explicativo observado para o setor 1 seja justificado pela existência de diferenças relacionadas aos estoques, tais como, as provisões para ajuste ao valor 
de mercado, a adoção de critério de avaliação não aceito tributariamente (UEPS, por exemplo) ou, até mesmo, divergências decorrentes de critérios de custeio (variável versus absorção, por exemplo), as quais não foram capturadas pelo modelo, dada a ausência de uma variável capaz de explicá-las. Essa presunção decorre do fato de que os estoques, comumente, representam um elemento patrimonial importante para o setor industrial.

As estimações não apresentam evidências de autocorrelação, muito embora isso não possa ser assegurado para o setor 2 (Comércio), uma vez que o teste Durbin-Watson foi inconclusivo. Os problemas relacionados à heterocedasticidade foram mitigados em função da estimação com erros padrão robustos. A média dos resíduos é zero e não há multicolinearidade entre as variáveis explicativas, exceto no setor 3 (Construção Civil), em relação à variável $A F D$ e a variável interativa $P J F 10 \times A F D$, mas que, entretanto, não compromete a estimação. Contudo, para todos os setores, os resíduos não apresentam distribuição normal.

A significância dos coeficientes varia entre os setores, com destaque para o setor 3, onde todas variáveis explicativas apresentaram coeficientes significativos. Neste setor, a estimação é capaz de explicar, aproximadamente, 69\% das variações das DCT. Essa constatação pode ser explicada pelo fato de que a apuração do lucro tributável nesse setor é fortemente influenciada pelo regime de caixa, sobretudo nas atividades de incorporação imobiliária, o que gera um maior volume de diferenças normais e, portanto, inerentes àquela sistemática de tributação.

O coeficiente de Invest é significativo e exibe o sinal previsto para os setores 3 a 6 , indicando que neles, as $D C T$ apresentam um maior nível de componentes associados às receitas e despesas decorrentes dos investimentos avaliados pelo método da equivalência patrimonial, componentes estes que representariam diferenças permanentes. O setor 5 apresenta a maior magnitude para esse coeficiente $(0,323)$, setor que apresentou menor média $(0,052)$ e maior coeficiente de variação $(2,885)$ para essa variável.

Com exceção do setor 2, observa-se que PJF10 exibe coeficientes negativos e estatisticamente significativos. Essa associação negativa sugere que as firmas com histórico de maior ocorrência de $L A I R<0$ tendem a efetuar menos ajustes na apuração do lucro tributável, no sentido de reduzir a tributação. Sendo assim, é possível considerar que esses resultados negativos podem não ter gerado prejuízo fiscal suficiente para compensação em períodos futuros ou então que essa parcela compensável tenha sido reduzida. Hipótese esta sinalizada pelas estatísticas descritivas. Contudo, isso não é uniforme, pois, como a variável interativa PJF10 $\times$ AFD apresenta associação positiva e significativa com as $D C T$ nos setores 3,5 e 6 (Outros), há a indicação da ocorrência de compensação de prejuízos fiscais apurados em período anteriores para tais setores. 
De uma maneira geral, as evidências indicam que as estimações também são afetadas pela idiossincrasia setorial, sugerindo, assim, que para cada setor, talvez, fosse recomendável estruturar um modelo específico, a fim de aumentar a poder explicativo das estimações.

A Tabela 11 exibe as estatísticas descritivas dos resíduos das estimações apresentadas na Tabela 10, os quais representam as DCTA.

Tabela 11 - Estatísticas Descritivas das DCTA.

\begin{tabular}{lcccccc}
\hline \multirow{2}{*}{ Estatísticas } & \multicolumn{7}{c}{ Setores } \\
\cline { 2 - 7 } & 1 & 2 & 3 & 4 & 5 & 6 \\
\hline Média & 0,000 & 0,000 & 0,000 & 0,000 & 0,000 & 0,000 \\
Desvio Padrão & 0,061 & 0,034 & 0,044 & 0,040 & 0,029 & 0,076 \\
Mínimo & $-0,436$ & $-0,169$ & $-0,112$ & $-0,106$ & $-0,117$ & $-0,367$ \\
Q05 & $-0,062$ & $-0,051$ & $-0,074$ & $-0,048$ & $-0,046$ & $-0,092$ \\
Q50 & $-0,004$ & $-0,000$ & $-0,000$ & $-0,004$ & $-0,001$ & $-0,004$ \\
Q95 & 0,097 & 0,054 & 0,088 & 0,072 & 0,043 & 0,117 \\
Máximo & 0,310 & 0,066 & 0,106 & 0,136 & 0,080 & 0,383 \\
\hline i) setor 1: Indúy
\end{tabular}

(i) setor 1: Indústria; (ii) setor 2: Comércio; (iii) setor 3: Construção Civil; (iv) setor 4: Serviços de Comunicação, Água e Energia; (v) setor 5: Transportes e serviços relacionados; e (vi) setor 6: Outros.

Fonte: dados da pesquisa

Como visto na Tabela 10, as DCTA somente apresentam distribuição normal para o setor 3. Pelas razões já expostas na seção anterior, a exigência quanto a tal distribuição foi relaxada. 


\subsection{Investigação e Teste das Hipóteses da Pesquisa}

Nesta seção são apresentados os resultados e análises relacionados às hipóteses de pesquisa formuladas na presente tese, os quais foram segregados de acordo com as 4 decisões analisadas teoricamente no Capítulo 3, a saber: (i) Decisão 1: $L^{+}=L C>L T(E S C=0 ; D C T A>0)$; (ii) Decisão: $L^{+}>L T=L C(E S C<0 ; D C T A=0)$; (iii) Decisão 3: $L C>L^{+}>L T(E S C>0$; DCTA $>0)$; e (iv) Decisão 4: $L^{+}>L C>L T(E S C<0 ; D C T A>0)$.

As hipóteses de pesquisa foram testadas por meio da análise da significância e direção dos coeficientes de resposta das variáveis de interesse (ESC, DCTA, Prob e Prob_Dif), obtidos com base nos modelos econométricos (32), (33), (34) e (35). Antes da discussão desses resultados, a seguir é apresentada a análise das estatísticas descritivas referentes às variáveis utilizadas nesses modelos.

\subsubsection{Análise Descritiva}

A Tabela 12 apresenta as estatísticas descritivas das variáveis empregadas nos modelos econométricos (32) e (33), as quais foram utilizadas na investigação e teste das hipóteses da pesquisa.

Tabela 12 - Estatísticas Descritivas - Variáveis das equações (32) e (33)

\begin{tabular}{lcccccccc}
\hline & Média & $\begin{array}{c}\text { Desvio } \\
\text { Padrão }\end{array}$ & Mínimo & Q05 & Q50 & Q95 & Máximo & $>0$ \\
\hline ESC & 0,083 & 0,427 & $-5,370$ & $-0,177$ & 0,039 & 0,555 & 5,368 & $64,54 \%$ \\
Prob & 0,046 & 0,013 & 0,020 & 0,026 & 0,046 & 0,067 & 0,067 & - \\
Prob_Dif & 0,191 & 0,127 & 0,000 & 0,000 & 0,275 & 0,292 & 0,292 & - \\
Prob_Dif ${ }^{\dagger}$ & 0,275 & 0,014 & 0,252 & 0,252 & 0,275 & 0,292 & 0,292 & - \\
DTCA & 0,000 & 0,054 & $-0,436$ & $-0,068$ & $-0,003$ & 0,083 & 0,383 & $45,39 \%$ \\
Inv_Inst & 0,051 & 0,126 & 0,000 & 0,000 & 0,000 & 0,245 & 1,000 & $44,21 \%$ \\
Gov & 0,359 & 0,480 & 0,000 & 0,000 & 0,000 & 1,000 & 1,000 & $35,93 \%$ \\
Rem & 0,461 & 0,499 & 0,000 & 0,000 & 0,000 & 1,000 & 1,000 & $46,10 \%$ \\
Analist & 2,461 & 4,664 & 0,000 & 0,000 & 0,000 & 14,000 & 18,000 & $27,19 \%$ \\
Big4 & 0,457 & 0,498 & 0,000 & 0,000 & 0,000 & 1,000 & 1000 & $45,74 \%$ \\
Endv & 0,623 & 3,888 & 0,000 & 0,000 & 0,281 & 0,638 & 65,160 & - \\
Ativo & 20,724 & 1,820 & 14,639 & 17,552 & 20,821 & 23,423 & 27,174 & - \\
\hline
\end{tabular}

$\boldsymbol{E S C}$ é a proxy para as escolhas contábeis oportunistas no ano $t$, mensurada com base no modelo Jones Modificado. Prob é a proxy da probabilidade de detecção tributária setorial no ano $t$, mensurada por meio da transformação proposta por Tversky e Kahneman (1992). da taxa de auditoria anual da $R F B$. Prob_Dif é a proxy da probabilidade de detecção tributária das firmas sujeitas ao acompanhamento diferenciado no ano $t$, mensurada por meio da transformação proposta por Tversky e Kahneman (1992). da taxa de auditoria anual da RFB. DCTA é a proxy para as estratégias de evasão tributária no ano $t$, mensurada com base na estimação do modelo (38). Inv_Inst é a proporção de investidores institucionais da firma. Gov é a variável dummy indicativa da adesão da firma aos segmentos de governança corporativa da BM\&FBovespa (Novo Mercado, Nível 1 ou Nível 2), que assume 1 caso a firma tenha efetuado tal adesão. Rem é a variável dummy que assume 1 caso a firma tenha utilizado remuneração variável para pagamento dos administradores no ano $t$. Analist representa a cobertura de analista, 
mensurada pelo número de analistas que acompanharam a firma no ano $t$. Big4 é a variável dummy representativa da qualidade da auditoria independente. Ela assume 1 caso as demonstrações contábeis da firma do ano $t$ tenham sido auditadas pelas firmas de auditoria Deloitte, EY, KPMG ou PWC. Endv representa a alavancagem financeira da firma no ano $t$; e Ativo é o log natural do ativo total do final do ano $t$.

$\uparrow$ Considerando apenas as firmas diferenciadas.

Número de observações: (i) amostra total - 846; (ii) firmas não submetidas ao acompanhamento diferenciado - 258; (iii) firmas submetidas ao acompanhamento diferenciado - 588 .

Fonte: dados da pesquisa.

Um ponto de interesse é avaliar a distribuição das variáveis condicionada à evolução de ESC e de DCTA, individualmente. Nesse sentido, a Tabela 13 apresenta as médias intra-quantis para cada variável, com distribuições ordenadas por ESC (Painel A) e por DCTA (Painel B).

Tabela 13 - Médias Intra-Quantis - Variáveis das equações (32) e (33)

Painel A - Distribuição ordenada por ESC

\begin{tabular}{lccccc}
\hline \multicolumn{1}{c}{ Variáveis } & $\mathrm{Q} 05$ & $\mathrm{Q} 25$ & $\begin{array}{c}\text { Médias } \\
\mathrm{Q} 50\end{array}$ & $\begin{array}{c}\mathrm{Q} 75 \\
(50)\end{array}$ & $\begin{array}{c}\mathrm{Q} 95 \\
(75-95)\end{array}$ \\
\hline ESC & $\mathbf{- 0 , 6 6 6}$ & $\mathbf{- 0 , 1 9 6}$ & $\mathbf{- 0 , 0 9 7}$ & $\mathbf{- 0 , 0 3 7}$ & $\mathbf{0 , 0 2 6}$ \\
\hline Prob & 0,044 & 0,043 & 0,043 & 0,043 & 0,045 \\
Prob_Dif & 0,107 & 0,193 & 0,202 & 0,198 & 0,190 \\
DTCA & $-0,022$ & $-0,010$ & $-0,009$ & $-0,004$ & $-0,0002$ \\
Inv_Inst & 0,031 & 0,039 & 0,038 & 0,042 & 0,052 \\
Gov & 0,069 & 0,269 & 0,335 & 0,361 & 0,363 \\
Rem & 0,186 & 0,330 & 0,399 & 0,451 & 0,463 \\
Analist & 0,674 & 1,865 & 2,201 & 2,418 & 2,558 \\
Big4 & 0,349 & 0,409 & 0,437 & 0,459 & 0,466 \\
Endv & 6,179 & 1,519 & 0,910 & 0,688 & 0,640 \\
Ativo & 19,066 & 20,536 & 20,912 & 20,830 & 20,766 \\
\hline
\end{tabular}

Panei B - Distribuição ordenada por DCTA

\begin{tabular}{|c|c|c|c|c|c|}
\hline \multirow[b]{2}{*}{ Variáveis } & \multicolumn{5}{|c|}{ Médias } \\
\hline & $\begin{array}{c}\text { Q05 } \\
(0-5)\end{array}$ & $\begin{array}{c}\mathrm{Q} 25 \\
(5-25) \\
\end{array}$ & $\begin{array}{c}\text { Q50 } \\
(25-50) \\
\end{array}$ & $\begin{array}{c}\text { Q75 } \\
(50-75) \\
\end{array}$ & $\begin{array}{c}\mathrm{Q} 95 \\
(75-95) \\
\end{array}$ \\
\hline DTCA & $-0,115$ & $-0,040$ & $-0,012$ & 0,009 & 0,041 \\
\hline$E S C$ & 0,037 & 0,104 & 0,091 & 0,039 & 0,094 \\
\hline Prob & 0,044 & 0,048 & 0,046 & 0,044 & 0,046 \\
\hline Prob_Dif & 0,147 & 0,206 & 0,199 & 0,186 & 0,198 \\
\hline Inv_Inst & 0,055 & 0,061 & 0,033 & 0,043 & 0,065 \\
\hline Gov & 0,395 & 0,395 & 0,341 & 0,292 & 0,376 \\
\hline Rem & 0,604 & 0,511 & 0,442 & 0,387 & 0,470 \\
\hline Analist & 3,070 & 2,628 & 2,279 & 2,226 & 2,753 \\
\hline Big4 & 0,558 & 0,482 & 0,423 & 0,452 & 0,488 \\
\hline$E n d v$ & 0,262 & 0,303 & 0,398 & 1,411 & 0,715 \\
\hline Ativo & 20,903 & 21,001 & 20,817 & 20,543 & 20,741 \\
\hline
\end{tabular}


ESC é a proxy para as escolhas contábeis oportunistas no ano $t$, mensurada com base no modelo Jones Modificado. Prob é a proxy da probabilidade de deteç̧ão tributária setorial no ano $t$, mensurada por meio da transformação proposta por Tversky e Kahneman (1992). da taxa de auditoria anual da RFB.Prob_Dif é a proxy da probabilidade de detecção tributária das firmas sujeitas ao acompanhamento diferenciado no ano $t$, mensurada por meio da transformação proposta por Tversky e Kahneman (1992). da taxa de auditoria anual da RFB. DCTA é a proxy para as estratégias de evasão tributária no ano $t$, mensurada com base na estimação do modelo (38). Inv_Inst é a proporção de investidores institucionais da firma. Gov é a variável dummy indicativa da adesão da firma aos segmentos de governança corporativa da BM\&FBovespa (Novo Mercado, Nível 1 ou Nível 2), que assume 1 caso a firma tenha efetuado tal adesão. Rem é a variável dummy que assume 1 caso a firma tenha utilizado remuneração variável para pagamento dos administradores no ano $t$. Analist representa a cobertura de analista, mensurada pelo número de analistas que acompanharam a firma no ano t. Big4 é a variável dummy representativa da qualidade da auditoria independente. Ela assume 1 caso as demonstrações contábeis da firma do ano $t$ tenham sido auditadas pelas firmas de auditoria Deloitte, EY, KPMG ou PWC. Endv representa a alavancagem financeira da firma no ano $t$; e Ativo é o $\log$ natural do ativo total do final do ano $t$.

Fonte: dados da pesquisa

A distribuição das médias de Prob, praticamente, não apresenta variação, diferentemente do que é visto para Prob_Dif que, apesar de não contar com um padrão evidente, exibe variação que acompanha a distribuição de ESC. Observa-se também que as médias das variáveis DCTA, Inv_Inst, Gov, Rem, Analist e Big4, seguem um padrão monotônico de elevação ao longo dos quantis da distribuição ordenada por ESC (Painel A).

Muito embora essas constatações sejam insuficientes para revelar uma relação associativa, elas sinalizam que as observações que apresentam os níveis mais baixos (elevados) para ESC também exibem menores (maiores) níveis para aquelas variáveis, o que sugere que aquela associação pode existir. Já em relação às DCTA, nenhum padrão foi observado.

A Tabela 14 apresenta as matrizes de correlação entre as variáveis ora analisadas. São exibidas as correlações de Pearson (paramétrica) e de Spearman (não paramétrica). 
Tabela 14 - Matrizes de Correlação - Pearson (parte inferior) e Spearman (parte superior)

\begin{tabular}{|c|c|c|c|c|c|c|c|c|c|c|c|}
\hline & $E S C$ & Prob & $\begin{array}{l}\text { Prob } \\
\text { Dif }\end{array}$ & $D C T A$ & $\begin{array}{l}\text { Inv } \\
\text { Inst }\end{array}$ & Gov & Rem & Analist & Big4 & $E n d v$ & Ativo \\
\hline$E S C$ & 1,000 & 0,269 & 0,031 & 0,130 & 0,195 & 0,062 & 0,131 & 0,074 & 0,041 & $-0,196$ & $-0,067$ \\
\hline Prob & 0,261 & 1,000 & 0,252 & $-0,016$ & 0,024 & $-0,015$ & $\underset{*}{0,066}$ & 0,374 & $\begin{array}{l}-0,059 \\
*\end{array}$ & $-0,030$ & 0,022 \\
\hline $\begin{array}{l}\text { Prob_ } \\
\text { Dif }\end{array}$ & 0,042 & 0,217 & 1,000 & $-0,014$ & 0,047 & 0,150 & 0,208 & $\underset{* * * *}{0,099}$ & 0,037 & 0,103 & 0,355 \\
\hline$D C T A$ & 0,056 & 0,000 & $-0,039$ & 1,000 & $-0,009$ & 0,026 & $-0,034$ & 0,024 & $-0,005$ & $\underset{\substack{* * \\
-0,077}}{-0,07}$ & $-0,071$ \\
\hline $\begin{array}{l}\text { Inv } \\
\text { Inst }\end{array}$ & 0 , & $-0,065$ & 1 & 5 & 1,000 & 0,533 & 0,514 & 0,510 & & $-0,113$ & 0,317 \\
\hline Gov & 0,014 & $-0,019$ & 0,185 & 0,054 & 0,357 & 1,000 & 0,662 & 0,606 & 0,227 & $-0,126$ & 0,513 \\
\hline Rem & 0 , & $\begin{array}{c}0,061 \\
*\end{array}$ & 0,257 & $-0,034$ & 0,254 & 0,662 & 1,000 & 0,545 & 0,193 & $-0,192$ & 0,491 \\
\hline Analist & $-0,005$ & $-0,074$ & 0,111 & 0,016 & 0,257 & $0,0,540$ & 0,498 & 1,000 & 0,331 & $\begin{array}{c}-0,059 \\
*\end{array}$ & 0,499 \\
\hline Big4 & $-0,000$ & $-0,061$ & 0,038 & $-0,032$ & 0,159 & 0,227 & 0,193 & 0,292 & 1,000 & 0,091 & 0,298 \\
\hline Endv & $-0,478$ & $-0,027$ & $-0,126$ & 0,031 & $-0,038$ & $-0,072$ & $-0,091$ & $-0,046$ & $-0,075$ & 1,000 & 0,029 \\
\hline Ativo & 0,030 & 0,049 & 0,488 & $\underset{* * *}{-0,061}$ & 0,125 & $\underset{\substack{0,47 * * \\
*}}{0,471}$ & $0, \underset{c}{* * * *} \mathfrak{c}$ & $\underset{* * * *}{0,462}$ & 0,270 & $-0,195$ & 1,000 \\
\hline
\end{tabular}

ESC é a proxy para as escolhas contábeis oportunistas no ano $t$, mensurada com base no modelo Jones Modificado. Prob é a proxy da probabilidade de detecção tributária setorial no ano $t$, mensurada por meio da transformação proposta por Tversky e Kahneman (1992). da taxa de auditoria anual da RFB.Prob_Dif é a proxy da probabilidade de detecção tributária das firmas sujeitas ao acompanhamento diferenciado no ano $t$, mensurada por meio da transformação proposta por Tversky e Kahneman (1992). da taxa de auditoria anual da RFB. DCTA é a proxy para as estratégias de evasão tributária no ano $t$, mensurada com base na estimação do modelo (38). Inv_Inst é a proporção de investidores institucionais da firma. Gov é a variável dummy indicativa da adesão da firma aos segmentos de governança corporativa da BM\&FBovespa (Novo Mercado, Nível 1 ou Nível 2), que assume 1 caso a firma tenha efetuado tal adesão. Rem é a variável dummy que assume 1 caso a firma tenha utilizado remuneração variável para pagamento dos administradores no ano $t$. Analist representa a cobertura de analista, mensurada pelo número de analistas que acompanharam a firma no ano $t$. Big4 é a variável dummy representativa da qualidade da auditoria independente. Ela assume 1 caso as demonstrações contábeis da firma do ano $t$ tenham sido auditadas pelas firmas de auditoria Deloitte, EY, KPMG ou PWC. Endv representa a alavancagem financeira da firma no ano $t$; e Ativo é o $\log$ natural do ativo total do final do ano $t$. Fonte: dados da pesquisa

Um aspecto que chama a atenção e que, em princípio, vai de encontro à hipótese $H l$, é a correlação positiva e significativa observada entre ESC e Prob, além da ausência de correlação significativa entre essa probabilidade e DCTA. No mesmo sentido, os resultados em relação à ESC e as variáveis Inv_Inst e Gov (correlação positiva e significativa) apresentados pelo coeficiente de Spearman também são intrigantes, uma vez que essas variáveis indicam que as firmas contam com mais mecanismos de governança e, portanto, era esperado que houvesse uma correlação negativa. 


\subsubsection{Endogeneidade entre $E S C$ e DCTA}

Sob a hipótese da complementaridade, as escolhas contábeis oportunistas e as estratégias de evasão tributária podem ser interdependentes, sendo possível que elas sejam simultaneamente determinadas, de modo que ESC e DCTA seriam parcialmente determinadas uma em função da outra. Nesta situação, sendo ESC dependente de DCTA, ou vice-versa, do ponto de vista econométrico, a variável independente seria correlacionada com os erros da estimação (endogeneidade), o que resultaria na estimação de coeficientes inconsistentes, caso a técnica adequada não fosse utilizada. A fim de investigar essa situação, foi realizado o teste de Hausman, cuja hipótese nula é que a variável independente é exógena.

Adicionalmente, no caso da equação (32), dado que ela é sobre-identificada, foi realizado o teste de Sargan, no intuito de avaliar a validade dos instrumentos utilizados na estimação da variável testada. Os resultados desses testes são apresentados na Tabela 15.

Tabela 15 - Endogeneidade entre ESC e DCTA - Resultados dos Testes de Hausman e de Sargan

\begin{tabular}{|c|c|c|c|}
\hline \multirow{2}{*}{ Estratos Amostrais/ Decisões } & \multirow{2}{*}{$\begin{array}{c}\text { DCTA } \\
\text { Equação (32) }\end{array}$} & \multicolumn{2}{|c|}{$\begin{array}{c}E S C \\
\text { Equação (33) }\end{array}$} \\
\hline & & $\begin{array}{l}\text { Hausman } \\
(p \text {-valor })\end{array}$ & $\begin{array}{l}\text { Sargan } \\
(p-\text { valor })\end{array}$ \\
\hline Amostra Total & $\begin{array}{c}0,095 \\
(0,7579)\end{array}$ & $\begin{array}{c}2,440 \\
(0,1183)\end{array}$ & $\begin{array}{c}0,6829 \\
(0,4085)\end{array}$ \\
\hline $\begin{array}{l}\text { Decisão } 1 \\
(\text { Amostra condicionada a } D C T A>0)\end{array}$ & $\begin{array}{c}0,008 \\
(0,9276)\end{array}$ & $\begin{array}{c}0,454 \\
(0,5000)\end{array}$ & $\begin{array}{c}0,056 \\
(0,8124)\end{array}$ \\
\hline $\begin{array}{l}\text { Decisão } 2 \\
\text { (Amostra condicionada a } E S C<0 \text { ) }\end{array}$ & $\begin{array}{c}0,342 \\
(0,5588)\end{array}$ & $\begin{array}{c}4,034 \\
(0,0446)\end{array}$ & $\begin{array}{c}0,824 \\
(0,3639)\end{array}$ \\
\hline $\begin{array}{l}\text { Decisão } 3 \\
(\text { Amostra condicionada a } E S C>0 \text { E } D C T A>0)\end{array}$ & $\begin{array}{c}0,359 \\
(0,5486)\end{array}$ & $\begin{array}{c}0,142 \\
(0,7059)\end{array}$ & $\begin{array}{c}0,573 \\
(0,4490)\end{array}$ \\
\hline $\begin{array}{l}\text { Decisão } 4 \\
(\text { Amostra condicionada a } E S C<0 \text { E } D C T A>0)\end{array}$ & $\begin{array}{c}0,063 \\
(0,8018)\end{array}$ & $\begin{array}{c}1,080 \\
(0,2986)\end{array}$ & $\begin{array}{c}0,0004 \\
(0,9838)\end{array}$ \\
\hline
\end{tabular}

Fonte: dados da pesquisa

Os resultados somente indicam que há endogeneidade para a variável ESC em relação à DCTA [equação (33)], especificamente na decisão $2(E S C<0)$, para a qual a estatística de Hausman rejeitou $H_{0}$ a um nível de significância de 5\%. Em função disso, a estimação dessa equação para tal decisão foi realizada por meio dos MQ2E. Entretanto, é importante salientar que, tendo em vista que os instrumentos utilizados se mostraram fracos ${ }^{62}$, os coeficientes dessa

\footnotetext{
${ }^{62}$ Essa avaliação é feita por meio da estatística $F$ da regressão de primeiro estágio. De acordo com Staiger e Stock (1997), estatísticas inferiores a 10 indicam que os instrumentos utilizados são fracos. No presente caso, essa estatística foi igual a 3,217.
} 
estimação, provavelmente, podem apresentar viés (STAIGER; STOCK, 1997; STOCK; YOGO, 2005).

\subsubsection{Probabilidade de Detecção Tributária e Escolhas Contábeis}

H1: há uma associação negativa e estatisticamente significativa entre a probabilidade de detecção tributária e as escolhas contábeis oportunistas realizadas pelas firmas brasileiras de capital aberto

Para a análise de $H 1$, foram considerados os resultados obtidos com base no modelo econométrico (32) referentes às variáveis Prob e Prob_Dif, os quais são evidenciados na Tabela 16. Os resultados completos das estimações realizadas constam no Apêndice B.

Tabela 16 - Resultados para a Probabilidade de Detecção Tributária - Equação (32)

Painel A Coeficientes de Prob

\begin{tabular}{|c|c|c|c|c|c|c|}
\hline & \multicolumn{6}{|c|}{ Coeficientes } \\
\hline & \multirow{2}{*}{$\begin{array}{c}\text { Regressão } \\
\text { com Base na } \\
\text { Média } \\
\text { Condicional }\end{array}$} & \multicolumn{5}{|c|}{ Regressão Quantílica } \\
\hline & & Q05 & Q25 & Q50 & Q75 & Q95 \\
\hline Amostra Total & $7,611^{* * *}$ & $-0,026$ & $2,053^{* * *}$ & $3,102^{* * *}$ & $4,416^{* * *}$ & $3,386^{* * *}$ \\
\hline Decisão 1 & $31,608^{* *}$ & 0,559 & $2,159^{* * *}$ & $3,041^{* * *}$ & $4,573^{* * *}$ & $2,917^{* * *}$ \\
\hline Decisão 2 & $-0,669$ & $-5,152^{* * *}$ & $-0,332$ & $-0,438$ & $-0,307^{*}$ & $-0,234^{* *}$ \\
\hline Decisão 3 & $8,544^{* * *}$ & 0,333 & $1,738^{* * *}$ & $3,158^{* * *}$ & $3,469^{* * *}$ & 2,155 \\
\hline Decisão 4 & $43,170^{*}$ & $-4,032^{* * *}$ & 0,249 & $-0,962$ & $-0,966^{* *}$ & $-0,487^{* * *}$ \\
\hline
\end{tabular}

Painel B Coeficientes de Prob_Dif

\begin{tabular}{|c|c|c|c|c|c|c|}
\hline & \multicolumn{6}{|c|}{ Coeficientes } \\
\hline & \multirow{2}{*}{$\begin{array}{c}\text { Regressão } \\
\text { com Base na } \\
\text { Média } \\
\text { Condicional }\end{array}$} & \multicolumn{5}{|c|}{ Regressão Quantílica } \\
\hline & & Q05 & Q25 & Q50 & Q75 & Q95 \\
\hline Amostra Total & $-0,187$ & $0,216^{* * *}$ & $-0,061$ & $-0,166^{* * *}$ & $-0,216^{* * *}$ & $-0,500^{* * *}$ \\
\hline Decisão 1 & $-1,114^{* * *}$ & $0,302^{* * *}$ & $-0,082$ & $-0,218^{* * *}$ & $-0,258^{* * *}$ & $-0,530^{* * *}$ \\
\hline Decisão 2 & 0,158 & $0,969^{*}$ & 0,099 & 0,009 & 0,009 & 0,002 \\
\hline Decisão 3 & $-0,521$ & $-0,037$ & $-0,104^{*}$ & $-0,221^{* *}$ & $-0,333^{* *}$ & $-0,414$ \\
\hline Decisão 4 & $-1,018$ & $1,314^{* *}$ & 0,206 & 0,043 & 0,019 & 0,014 \\
\hline
\end{tabular}

A amostral total compreende todas as observações firmas-ano. Decisão 1 somente considera aquelas observações em que DCTA > 0. Em Decisão 2 são consideradas apenas observações em que $E S C>0$. Para Decisão 3, as observações incluídas são aquelas em que $E S C>0$ e DCTA > 0. Já em Decisão 4, são consideradas as observações em que $E S C<0$ e $D C T A>0$. 
As estimações da amostra total e da decisão 3 foram realizadas com o emprego dos MQO. Para as demais estratificações, foi utilizado dados em painel com efeitos fixos

$*, * * \mathrm{e} * * *$ indicam a significância estatística bicaudal a $10 \%, 5 \%$; e $1 \%$, respectivamente.

Fonte: dados da pesquisa

Os resultados demonstram que não há um padrão associativo definido entre as proxies da probabilidade de detecção e ESC. A magnitude, significância e direção dos coeficientes dessas proxies depende do tipo de decisão e do nível de ESC.

Em relação a Prob, verifica-se que somente nas decisões que envolvem ESC $<0$ (decisões 2 e 4), há uma associação negativa e significativa no menor nível dessa variável (Q05) e nos seus níveis mais elevados (Q75 e Q95), constatação que se alinha à $H 1$. Contudo, a preponderância de coeficientes positivos e significativos nas demais decisões é intrigante e contraria os pressupostos teóricos que fundamentam essa hipótese.

O resultados obtidos para Prob_Dif apresentam evidências mais contundentes em favor de $H 1$, pois observa-se um padrão de crescimento monotônico da associação negativa com ESC ao longo dos quantis, o qual é exibido pelos coeficientes estimados na amostra total, assim como nas decisões 1 e 3. De uma maneira geral, há um número maior de ocorrências para coeficientes negativos de Prob_Dif, muito embora a maioria não seja estatisticamente significativa. ${ }^{63}$

Com base nas proposições $2 a$ e $2 b$, formuladas e provadas na seção 3.2.2, tem-se que os agentes não realizariam escolhas oportunistas que reduzissem o lucro contábil, exclusivamente, em resposta a incentivos tributários. Conforme demonstrado, tais escolhas somente serão implementadas se o benefício líquido de divulgação financeira gerado for superior à redução da utilidade marginal total da aposta da evasão tributária [condição dada pela equação (17)], redução que é diretamente afetada por Prob.

Sendo assim, uma possível explicação para os resultados de Prob alinhados a $H 1$, seria que nos níveis mais baixos da distribuição de ESC (mais negativo), aquela associação negativa decorreria do efeito conjunto do risco de detecção e dos custos de divulgação financeira, uma vez que estes tendem a ser maiores para os maiores níveis de oportunismo. Entretanto, as variáveis que podem refletir tais custos (Inv_Inst, Gov, Rem e Analist) não corroboram essa explicação.

Por outro lado, nos níveis mais elevados, onde ESC aproxima-se de zero, é possível que o benefício da escolha oportunista tenha se mostrado reduzido, a ponto de se tornar insuficiente

\footnotetext{
${ }^{63}$ Constatações semelhantes foram realizadas quando consideradas as $D C T$ ao invés das DCTA. Essa verificação foi meramente exploratória. Os resultados não foram aqui reportados.
} 
para atender a condição dada por (17) (seção 3.2.2), ante o custo de detecção, de modo que pequenas variações em $\operatorname{Prob}$ poderiam inviabilizar $E S C<0$.

Já os resultados verificados para Prob_Dif indicam que, para as firmas diferenciadas, o risco de detecção exerceria a influência (apresentaria a associação) esperada sobre ESC naqueles casos em que as decisões implicassem em DCTA >0, sem, necessariamente, que houvesse redução do lucro contábil (decisões 1 e 3), o que é condizente com as proposições 1 (seção 3.2.1) e $3 b$ (seção 3.2.3), bem como com a ideia elementar da complementaridade, em que a governança tributária restringiria o oportunismo gerencial, devido ao efeito feedback positivo, tal qual demonstrado para a proposição $3 a$ (seção 3.2.3), o que não é visto para as firmas em geral.

Essa constatação é reforçada pelos resultados obtidos para Prob_Dif com o modelo (33), uma vez que, nos níveis mais elevados da distribuição de DCTA e DCT, também se verificam associações negativas, o que será comentado na seção seguinte.

Adicionalmente, deve ser considerado o fato de que as firmas diferenciadas tendem a ser politicamente mais sensíveis à governança tributária, haja vista o maior monitoramento tributário, de modo que evitariam implementar escolhas oportunistas associadas a decisões em que DCTA > 0, em função da percepção quanto ao aumento do risco de detecção provocado por tais estratégias.

Quanto às associações positivas observadas, sobretudo para Prob, a estrutura teóricoanalítica aqui explorada não é capaz de oferecer explicações satisfatórias, com base nos dados analisados. Contudo, os resultados obtidos podem indicar, por exemplo, que os arranjos contratuais seriam incompletos, na medida em que não submeteriam os agentes a qualquer ônus decorrente dos custos de detecção, de modo que eles seriam indiferentes a esse evento e somente responderiam aos incentivos e restrições relacionados à divulgação financeira, cujo efeito líquido, para algumas decisões, seria positivamente correlacionado com as variações setor-ano de Prob.

Entretanto, um aspecto que merece ser considerado é a percepção de risco do agente, ou seja, a probabilidade de detecção subjetiva. Muito embora essa argumentação seja controversa, haja vista a sua parcialidade, já que está sendo aplicada para apenas uma parte dos resultados, tem-se que as magnitudes de Prob e Prob_Dif podem estar subestimadas, mesmo após a transformação realizada, e não representar adequadamente a percepção do agente em algumas decisões.

As taxas aqui analisadas variam entre $2 \%$ e 6,7\% para Prob, ao longo dos setores e anos, e entre 25,2\% e 29,2\% para Prob_Dif, ao longo dos anos. Dentre os resultados encontrados, 
aqueles relacionados a Prob_Dif, justamente as taxas mais elevadas, ajustam-se melhor às expectativas derivadas da teoria.

Por outro lado, deve-se também considerar o fato de que os níveis reais das probabilidades de detecção podem não oferecer, efetivamente e de forma generalizada, um grau de risco de detecção suficiente a ponto de afetar, sistematicamente, o oportunismo gerencial dos agentes, o que não contraria os pressupostos teóricos que fundamentam $H 1$, muito embora implique na rejeição dessa hipótese.

Sob a teoria econômica da evasão tributária, tem-se que o indivíduo avesso ao risco somente implementaria a evasão tributária se, no ponto em que a evasão é zero, $\frac{(1-P r o b)}{\text { Prob }}>\pi$, onde $\pi$ é o percentual de penalidade aplicável sobre o tributo evadido (ALLINGHAM; SANDMO, 1972; YITIZHAKI, 1974; BERNASCONI, 1998; HINDRICKS; MYLES, 2006).

Para se ter uma ideia mais realista, tem-se que, considerando as penalidades de $75 \% \mathrm{e}$ $150 \%$ previstas em lei, a evasão tributária da firma, na ausência de conflitos de agência, provavelmente ocorreria sempre que Prob $<57,14 \%$ ou Prob $<40 \%{ }^{64}$. Em um contexto de agência, tal qual o considerado na estrutura teórico-analítica proposta nesta tese, esses limites também dependerão dos níveis da remuneração variável $(\omega)$ e do custo de detecção $(\eta)$ atribuídos contratualmente para o agente, bem como dos custos de divulgação financeira e da qualidade dos mecanismos de governança.

Por exemplo, considerando a decisão 1, a condição de entrada para evasão seria $\frac{(1-\text { Prob })}{\text { Prob }}>\frac{\eta \pi}{\omega}$. Assumindo que $\eta=0,5$ e $\omega=0,05$, tem-se que algum nível de evasão ocorreria se $\operatorname{Prob}<11,76 \%$, no caso da multa de $75 \%$, e Prob $<6,25 \%$, para a multa de $150 \%$.

Nesse sentido, vale salientar que, nos estudos internacionais cujos resultados alinhamse à $H 1$, os níveis das taxas de auditoria são superiores aos aqui verificados. Por exemplo, a probabilidade (taxa) de auditoria analisada em Hanlon, Hoopes e Shroff (2014) apresentou média entre 25\% e 40\%. Já El Ghoul, Guedhami e Pittman (2011) utilizaram taxas médias acima de $30 \%$. Para se ter ideia, aproximadamente $85 \%$ dos registros utilizados para o cálculo dessas taxas médias nesse estudo, consistia em percentuais superiores a 30\%, alguns deles alcançando mais de 50\%. Outro exemplo é Hoopes, Mescall e Pittman (2013), cuja taxa de auditoria analisada variou entre $19 \%$ e $37 \%$.

\footnotetext{
${ }^{64}$ Se considerada a possibilidade legal de redução em $50 \%$ das multas, esses percentuais passam para, aproximadamente, $72,73 \%$ e $57,14 \%$.
} 
Outra explicação para os resultados que rejeitam $H 1$, embora estranha à estrutura teórico-analítica aqui considerada, é que, em determinadas decisões, os agentes seriam propensos (amantes) ao risco. Sendo assim, o risco de detecção e ESC poderiam exibir uma associação positiva.

\subsubsection{Governança Corporativa, Probabilidade de Detecção Tributária e Escolhas Contábeis}

H2: a associação negativa entre a probabilidade de detecção tributária e as escolhas contábeis oportunistas realizadas pelas firmas brasileiras de capital aberto é mais forte quando os mecanismos de governança corporativa são mais fracos.

Há evidências indicativas de que a governança corporativa reduz o oportunismo gerencial por meio de escolhas contábeis (MARTINEZ, 2001; BARROS; SOARES; LIMA, 2013; MAN; WONG, 2013). Sendo assim, sob a hipótese da complementaridade, tem-se que a existência de mecanismos de governança eficientes também restringiria a evasão tributária, uma vez que esta não ofereceria benefícios adicionais para os agentes. Portanto, nessas circunstâncias, os efeitos da probabilidade de detecção tributária sobre as escolhas contábeis oportunistas serão limitados, pois, não haveria o que se esconder.

As duas variáveis representativas da adoção de práticas de governança corporativa de qualidade utilizadas no modelo (32) foram Inv_Inst e Gov. De uma maneira geral, os coeficientes dessas variáveis não evidenciam, de forma sistemática, uma associação negativa e estatisticamente significativa com ESC, tal qual esperado. Verificam-se tais resultados de forma esparsa ao longo das decisões e dos quantis analisados, entretanto, eles não permitem concluir que as práticas de governança corporativa associadas à maior proporção de investidores institucionais ou à adesão aos níveis de governança da BM\&FBovespa afetariam as escolhas contábeis oportunistas.

A fim de avaliar e testar $H 2$, foi utilizado o modelo (34), cujos resultados, para a amostra total e para as decisões teóricas, constam no Apêndice C. A análise desses resultados é apresentada a seguir. 


\section{Presença de Investidores Institucionais}

Para Inv_Inst, há a indicação de que o efeito de Prob e Prob_Dif difere entre as firmas que possuem investidores institucionais e aquelas que não. Isso é evidenciado pela magnitude, significância e direção dos coeficientes daquelas variáveis e de Prob x Inv_Inst e Prob_Dif x Inv_Inst, respectivamente.

No caso das firmas em geral (não diferenciadas), os resultados seguem a verificação geral: não há um padrão associativo definido, muito embora seja comum observar a inversão da direção dos coeficientes de Prob $x$ Inv_Inst em relação aos de Prob, apesar daqueles coeficientes, em sua maioria, não se mostrarem significativos. Entretanto, especificamente nas decisões 3 e 4, os resultados indicam um comportamento diferente.

Na decisão 3, Prob exibiu coeficientes positivos e significativos, o que já foi discutido na seção anterior. No entanto, naqueles resultados, os efeitos relacionados a Inv_Inst não haviam sido segregados e capturados de forma específica. Sendo assim, juntamente com tais resultados, a constatação referente às associações negativas e significativas verificadas para Prob $x$ Inv_Inst revela que a presença de investidores institucionais, por si só, não seria suficiente para restringir $E S C$, mas que, no entanto, essa característica tornaria os agentes mais sensíveis ao risco de detecção.

Desse modo, é possível que, nesses casos, os agentes busquem reduzir ESC somente quando enfrentam maiores riscos de detecção, pois, sob tal risco, aumentariam as chances de suas escolhas contábeis oportunistas serem descobertas. Sob essa interpretação, as práticas de governança associadas aos investidores institucionais e a governança tributária somente seriam eficazes conjuntamente. É válido lembrar que, sob a decisão 3, é mais provável que as firmas exibam maiores $D C T(E S C>0$ e $D C T A>0)$, número que pode ser monitorado tanto pelos investidores institucionais quanto pela autoridade.

Contudo, o que se observa na decisão 4 não segue essa lógica e se mostra condizente com $H 2$. Verifica-se que, na ausência de investidores institucionais, coeficientes negativos e significativos para todos quantis, em consonância com H1. Aqui, entretanto, as evidências observadas se mostram mais contundentes do que aquelas apresentadas para Prob na seção anterior. Na presença daqueles investidores, os coeficientes de Prob x Inv_Inst não exibem um padrão definido e somente apresentam um coeficiente negativo e significativo (Q25).

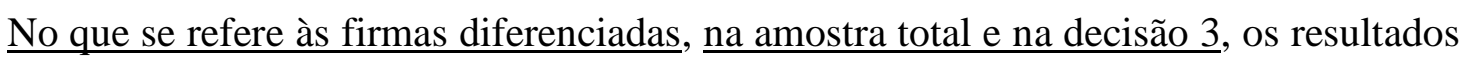
suportam H2: a associação entre Prob_Dif e ESC é mais fraca na presença de investidores 
institucionais. Essa conclusão é evidente quando comparados os coeficientes estimados para Prob_Dif e Prob_Dif x Inv_Inst.

Sob a decisão 3, na ausência daqueles investidores, há uma associação negativa, significativa e com crescimento quase monotônico, superando, inclusive, o que foi constatado por meio da equação (32) (seção 5.4.3). Do contrário, verifica-se que Prob_Difx Inv_Inst exibe parte dos coeficientes positivos (Q05, Q25 e Q75), sendo um deles negativo, e apenas para Q95 apresenta um coeficiente negativo e significativo, apesar de maior intensidade se comparado ao de Prob.

Para a decisão 1, observa-se que os efeitos de Prob_Dif seriam mais fortes na presença de investidores institucionais, sugerindo que a atuação conjunta das governanças corporativa e tributária seriam capazes de restringir o oportunismo gerencial.

Já para as decisões 2 e 4, não se observam resultados que sinalizem um comportamento diferente em razão da presença ou não de investidores institucionais, sugerindo, assim, que, sob tais decisões, os agentes seriam indiferentes ao risco de detecção, ou até mesmo propensos a esse risco, dado os coeficientes positivos e significativos obtidos, o que se mostra mais forte, na ausência daqueles investidores.

\section{Adesão ao Níveis de Governança Corporativa da BM\&FBovespa (NM, N1 ou N2)}

Partindo das firmas em geral (não diferenciadas), observam-se resultados mais contundentes do que aqueles obtidos para Inv_Inst, muito embora contrários a $H 2$.

Para a amostra total, assim como para as decisões 1 e 3, os resultados evidenciam, sob um padrão quase monotônico, que a associação entre Prob $x$ Gov e ESC é mais forte e segue a direção esperada para o risco de detecção. Um aspecto interessante é que para essas decisões, a análise geral não evidenciou essa associação (seção 5.4.3), a qual somente foi revelada com a segregação aqui realizada. Assim como visto para Inv_Inst, essa constatação evidencia os efeitos da atuação conjunta das governanças corporativa e tributária.

Para a decisão 2, observam-se resultados semelhantes, muito embora com menor intensidade e sem um padrão evidente, mas que também sugerem aquela atuação conjunta. Já para a decisão 4, os resultados não permitem concluir que há alguma diferença entre as associações analisadas.

Voltando a atenção para as firmas diferenciadas, tem-se que as evidências capazes de suportar H2 são limitadas. Os coeficientes de Prob_Dif x Gov são, em sua grande maioria, negativos, porém, as ocorrências de significância estatística são escassas. 
Para a amostra total e para a decisão 1, os resultados sugerem que há uma maior sensibilidade ao risco de detecção nas firmas com governança, notadamente, no nível mais baixo da distribuição de ESC (Q05). O que também é observado para Q05 na decisão 4.

É válido destacar que, na análise de $H 1$ (seção 5.4.3), foram observados resultados que indicavam uma associação negativa entre Prob_Dif e ESC, o que também é verificado aqui. Entretanto, os resultados ora analisados sugerem que, além da estratégia e do nível de ESC, o efeito da probabilidade de detecção para as firmas diferenciadas, aparentemente, também é condicionado às práticas de governança corporativa associadas aos segmentos da BM\&FBovespa. Muito embora os resultados não indiquem a existência de um padrão definido.

\subsubsection{Probabilidade de Detecção Tributária e Ajustes Tributários}

H3: há uma associação negativa e estatisticamente significativa entre a probabilidade de detecção tributária e os ajustes tributários anormais realizados pelas firmas brasileiras de capital aberto.

H4: há uma associação negativa e estatisticamente significativa entre a probabilidade de detecção tributária e os ajustes tributários totais realizados pelas firmas brasileiras de capital aberto.

A associação negativa entre a probabilidade de detecção tributária e DCTA é mais intuitiva, uma vez que essas diferenças afetam diretamente a apuração dos tributos. As diferenças entre o lucro contábil e o lucro tributável podem indicar a existência de estratégias evasivas e, desse modo, podem receber maior atenção da autoridade. Sendo assim, maiores diferenças implicariam em maior risco de detecção. Mills (1996, 1998), Cloyd et al. (1996) e Mills e Sansing (2000) apresentam evidências que apontam nessa direção. Em resumo, essa é a lógica teórica que fundamenta $\mathrm{H3}$ e $\mathrm{H} 4$, a qual é discutida e demonstrada no Capítulo 3.

Para testar $H 3$, a metodologia adotada foi semelhante àquela empregada na avaliação de $H 1$, no entanto, a análise foi realizada com base nos resultados obtidos com a equação (33), cuja variável dependente é DCTA. A Tabela 17 apresenta os resultados relativos aos coeficientes das variáveis Prob e Prob_Dif. Os resultados completos constam no Apêndice D. 
Tabela 17 - Resultados para a probabilidade de detecção tributária- Equação (33): variável dependente: DCTA

Painel A - Coeficientes de Prob

\begin{tabular}{|c|c|c|c|c|c|c|}
\hline & \multicolumn{6}{|c|}{ Coeficientes } \\
\hline & \multirow{2}{*}{$\begin{array}{c}\text { Regressão } \\
\text { com Base } \\
\text { na Média } \\
\text { Condicional }\end{array}$} & \multicolumn{5}{|c|}{ Regressão Quantílica } \\
\hline & & Q05 & Q25 & Q50 & Q75 & Q95 \\
\hline Amostra Total & $-0,008$ & $-0,302$ & $-0,176$ & $-0,122$ & $-0,026$ & $0,561^{* *}$ \\
\hline Decisão 1 & $-0,082$ & 0,004 & $0,139^{* *}$ & 0,033 & $0,534^{* * *}$ & $0,658^{* *}$ \\
\hline Decisão 2 & $-0,388$ & $-1,597^{* * *}$ & $-0,457^{* *}$ & $-0,262^{*}$ & $-0,008$ & $0,879^{* * *}$ \\
\hline Decisão 3 & $-0,023$ & 0,008 & 0,134 & $-0,023$ & $0,522^{*}$ & 0,923 \\
\hline Decisão 4 & $0,538^{* *}$ & $0,108^{* *}$ & 0,226 & $0,523^{* *}$ & $0,807^{* *}$ & $1,917^{* * *}$ \\
\hline
\end{tabular}

Painel B - Coeficientes de Prob_Dif

\begin{tabular}{|c|c|c|c|c|c|c|}
\hline & \multicolumn{6}{|c|}{ Coeficientes } \\
\hline & \multirow{2}{*}{$\begin{array}{l}\text { Regressão } \\
\text { com Base } \\
\text { na Média } \\
\text { Condicional }\end{array}$} & \multicolumn{5}{|c|}{ Regressão Quantílica } \\
\hline & & Q05 & Q25 & Q50 & Q75 & Q95 \\
\hline Amostra Total & $-0,0005$ & $0,091^{* * *}$ & 0,017 & 0,013 & $-0,003$ & $-0,085^{\text {*** }}$ \\
\hline Decisão 1 & $-0,032$ & $0,009^{* *}$ & 0,007 & $-0,005$ & $-0,059^{* * *}$ & $-0,144^{* * *}$ \\
\hline Decisão 2 & 0,017 & 0,029 & $-0,006$ & 0,019 & $0,048^{* * *}$ & $-0,003$ \\
\hline Decisão 3 & $-0,061^{*}$ & 0,003 & $-0,012$ & $-0,046^{*}$ & $-0,074^{* *}$ & $-0,181^{* * *}$ \\
\hline Decisão 4 & 0,025 & $0,018^{* * *}$ & $0,043^{* * *}$ & $0,051^{* * *}$ & 0,032 & $-0,002$ \\
\hline
\end{tabular}

A amostral total compreende todas as observações firmas-ano. Decisão 1 somente considera aquelas observações em que DCTA > 0. Em Decisão 2 são consideradas apenas observações em que ESC $>0$. Para Decisão 3, as observações incluídas são aquelas em que $E S C>0$ e DCTA > 0. Já em Decisão 4, são consideradas as observações em que $E S C<0$ e $D C T A>0$.

A estimação da decisão 2 foi realizada por MQ2E. Para a amostra total e as demais decisões utilizou-se de dados em painel com efeitos aleatórios.

$*, * *$ e *** indicam a significância estatística bicaudal a 10\%,5\%; e 1\%, respectivamente.

Fonte: dados da pesquisa.

Para Prob, verifica-se que, na amostra total, a maioria dos coeficientes exibe o sinal esperado, porém não apresentam significância estatística. Já no Q95, o coeficiente é positivo e significativo, contrariando $H 2$, o que se repetiu nas decisões 1,2 e 3 . Não há um padrão de resposta entre os resultados, mas, de uma maneira geral, eles não suportam $H 2$.

Em relação a Prob_Dif, observa-se um cenário ligeiramente diferente. Nas decisões 1 e 3 verificam-se coeficientes negativos e estatisticamente significativos para Q75 e Q95, bem como no Q95 da amostra total. Resultados que se alinham às constatações realizadas para ESC 
e sugerem a existência de feedback positivo nessas circunstâncias, em função da governança tributária, o que está de acordo com as proposições $3 a$ e $3 b$ (seção 3.2.3).

Quanto aos resultados não condizentes com $H 2$, as explicações apresentadas na seção 5.3.3 também se mostram pertinentes. No entanto, um aspecto que merece atenção é o fato de que a autoridade não observa diretamente o nível de $D C T A$, essa é uma informação privada do agente. No entanto, a autoridade é capaz de observar as $D C T$ e, com base nelas, definir as firmas que serão auditadas. Sendo assim, os agentes podem direcionar suas estratégias evasivas pelo nível das $D C T$, de modo que a associação negativa aqui investigada poderia se revelar em relação a essa variável. Essa suposição alinha-se à Premissa 3 da estrutura teórico-analítica analisada no Capítulo 3

A fim de explorar essa possibilidade, a equação (33) também foi estimada considerando as DCT como variável dependente ${ }^{65}$. Os resultados relativos a Prob e Prob_Dif são apresentados na Tabela 18. Os resultados completos constam no Apêndice E.

Tabela 18 - Resultados para a probabilidade de detecção Tributária - Equação (33) : variável dependente: $D C T$

Painel A - Coeficientes de Prob

\begin{tabular}{|c|c|c|c|c|c|c|}
\hline & \multicolumn{6}{|c|}{$\begin{array}{c}\text { Coeficientes } \\
\text { (estatísticas } t \text { ) }\end{array}$} \\
\hline & \multirow{2}{*}{$\begin{array}{l}\text { Regressão } \\
\text { com Base } \\
\text { na Média } \\
\text { Condicional }\end{array}$} & \multicolumn{5}{|c|}{ Regressão Quantílica } \\
\hline & & Q05 & Q25 & Q50 & Q75 & Q95 \\
\hline Amostra Total & $-0,315$ & $-0,337^{* * *}$ & $-0,019$ & $-0,028$ & 0,127 & $1,231^{\text {*** }}$ \\
\hline Decisão 1 & $-4,700$ & $-0,019$ & $-0,016$ & $0,262^{* *}$ & 0,175 & $1,056^{* * *}$ \\
\hline Decisão 2 & $-0,369$ & $-1,169^{* * *}$ & $-0,066$ & $-0,125^{* *}$ & $-0,222$ & $1,533^{* *}$ \\
\hline Decisão 3 & 0,840 & 0,056 & 0,026 & $0,413^{* *}$ & 0,175 & 0,406 \\
\hline Decisão 4 & 1,188 & $0,050^{* * *}$ & 0,078 & 0,036 & 0,617 & $1,590^{* * *}$ \\
\hline
\end{tabular}

65 A equação (32) também foi estimada com a substituição de DCTA por DCT. Os resultados foram semelhantes ao obtidos com os verificados com base na configuração original. 


\begin{tabular}{|c|c|c|c|c|c|c|}
\hline & \multicolumn{6}{|c|}{ Coeficientes } \\
\hline & \multirow{2}{*}{$\begin{array}{c}\text { Regressão } \\
\text { com Base } \\
\text { na Média } \\
\text { Condicional }\end{array}$} & \multicolumn{5}{|c|}{ Regressão Quantílica } \\
\hline & & Q05 & Q25 & Q50 & Q75 & Q95 \\
\hline Amostra Total & $-0,135^{* * *}$ & 0,016 & $-0,010^{* *}$ & $-0,012$ & $-0,153^{* * *}$ & $-0,517^{* * * *}$ \\
\hline Decisão 1 & $-0,151^{*}$ & $-0,003$ & $-0,044^{* * *}$ & $-0,013^{* * * *}$ & $-0,347^{* * *}$ & $-0,552^{* * * *}$ \\
\hline Decisão 2 & $-0,066^{*}$ & $-0,089^{* * *}$ & $-0,057^{* * *}$ & $-0,001$ & 0,010 & $-0,221^{* * * *}$ \\
\hline Decisão 3 & $-0,069$ & $-0,018$ & $-0,047^{* * *}$ & $-0,185^{* * *}$ & $-0,316^{* * * *}$ & $-0,650^{* * * *}$ \\
\hline Decisão 4 & $-0,138^{* *}$ & $-0,015$ & $-0,027^{* * *}$ & $-0,037$ & $-0,120^{*}$ & $-0,276^{* * * *}$ \\
\hline
\end{tabular}

A amostral total compreende todas as observações firmas-ano. Decisão 1 somente considera aquelas observações em que $D C T>0$. Em Decisão 2 são consideradas apenas observações em que $E S C>0$. Para Decisão 3, as observações incluídas são aquelas em que $E S C>0$ e DCT > 0. Já em Decisão 4, são consideradas as observações em que $E S C<0$ e $D C T>0$. A estimação da amostra total foi realizada com a utilização dos MQO. Para as decisões 1 e 4, foi empregada a técnica MQ2E. Nas estimações das decisões 2 e 3, utilizou-se dados em painel com efeitos aleatórios.

*, ** e *** indicam a significância estatística bicaudal a 10\%,5\%; e 1\%, respectivamente.

Fonte: dados da pesquisa.

No que se refere a Prob, os resultados não diferem substancialmente daqueles obtidos para DCTA. Há um número praticamente igual de ocorrências em que o coeficiente é positivo e significante, porém com pequenas alterações na distribuição de tais ocorrências ao longo dos quantis. Essas constatações também podem ser explicadas com base nos argumentos apresentados na seção 5.3.3.

Contudo, para Prob_Dif, os resultados revelam a existência de um padrão associativo ao longo dos quantis. Com exceção da decisão 2, todas as demais apresentaram coeficientes negativos e, na sua maioria, significativos, em que há um crescimento monotônico na direção dos níveis mais elevados da distribuição das $D C T$. Na amostra geral isso também é verificado a partir de Q25.

Essas constatações sugerem que os agentes das firmas diferenciadas buscam minimizar o risco de detecção por meio dos ajustes tributários totais. A questão é que, conforme demonstrado no Capítulo 3, aumentos nos ajustes tributários evasivos (y) acarretam aumentos na probabilidade de detecção percebida pelo agente, de modo que a escolha ótima de $y\left(y^{*}\right)$ tende a ser menor para cada unidade adicional dessa variável. Da mesma forma, aumentos naquela probabilidade que independam de $y$, também reduz o nível de $y^{*}$.

Esse é um aspecto interessante, pois, sob essa interpretação, é possível considerar que os agentes seriam sensíveis ao risco de detecção naquelas estratégias evasivas que implicassem 
maiores $D C T$ e não exclusivamente em relação aos níveis de $D C T A$. Isso é condizente com os pressupostos teóricos aqui assumidos, muito embora não tenha sido possível avaliar, empiricamente, a causalidade subjacente à associação verificada.

É possível que os agentes percebam que a probabilidade de detecção seria endógena às $D C T$ e, assim, busquem reduzir tais diferenças, o que, individualmente para uma determinada decisão tributariamente evasiva, guardaria relação direta com a redução das DCTA. Por outro lado, pode ser que a redução nos níveis de $D C T$ seja uma resposta aos aumentos verificados no nível de atuação da autoridade, mas que não exerça influência significativa sobre as DCTA, como sugerem os resultados aqui obtidos para essa variável.

No entanto, vale salientar que justamente nas decisões que, necessariamente, envolvem DCTA > 0 (decisões 1 e 3), as firmas diferenciadas exibiram uma associação negativa e significativa entre Prob_Dif e ESC, o que reforça a primeira explicação.

Adicionalmente, ao confrontar os resultados obtidos para Prob e para Prob_Dif relacionados às $D C T$, é possível verificar que as firmas diferenciadas são politicamente mais sensíveis, dado o maior nível de monitoramento tributário, o que se alinha aos pressupostos teóricos da hipótese dos custos políticos (tamanho). Essa característica afetaria o comportamento tributário dos agentes.

Outrossim, os resultados observados para Prob sugerem que o nível de atuação fiscalizatória tributária aparenta ser insuficiente para afetar a percepção de risco dos agentes das firmas em geral, o que também foi constatado quando da análise relacionada à ESC (seção 5.3.3). No entanto, o que torna os resultados aqui mais contundentes é o fato que as variáveis analisadas são de natureza eminentemente tributária, inclusive, as DCT são passíveis de observação. Esse é um aspecto importante, porque se o risco de detecção é baixo ou é assim percebido pelos agentes, a complementaridade, tal qual como teoricamente concebida, pode não ser observada. 


\subsubsection{Governança Corporativa, Probabilidade de Detecção Tributária e Ajustes Tributários Anormais}

H5: a associação negativa entre a probabilidade de detecção tributária e os ajustes tributários anormais realizados pelas firmas brasileiras de capital aberto é mais forte quando os mecanismos de governança corporativa são mais fracos.

Sob a complementaridade, a probabilidade de detecção tributária restringiria o oportunismo gerencial, devido à redução da evasão tributária. Parte dos resultados até aqui analisados sugerem que isso seria verdadeiro. Do mesmo modo, os mecanismos de governança tributária também restringiriam a evasão, na medida em que seriam capazes de reduzir o oportunismo gerencial.

As variáveis indicativas de boas práticas de governança consideradas na presente análise são a participação de investidores institucionais (Inv_Inst), a adesão a um dos segmentos de governança corporativa da BM\&FBovespa $(G o v)$. Elas foram incluídas como variáveis de controle na equação (33), tal qual definido para a equação (32).

De uma maneira geral, os resultados das estimações da equação (33) indicam que tais mecanismos também exercem influência sobre DCTA, mas que ela seria muita limitada (Apêndice D). As ocorrências de associações negativas e estatisticamente significativas, tal qual esperado, são muito pontuais e rarefeitas ao longo das estratégias e dos quantis. Sendo assim, tais constatações não permitem afirmar que a governança corporativa restringiria a evasão tributária por meio de ajustes tributários anormais.

Outrossim, tais resultados também não suportam a hipótese de existência de uma associação negativa entre as DCTA e a probabilidade de detecção, conforme já discutido na seção anterior (5.4.5).

Essas constatações, por si só, oferecem evidências preliminares que contrariam $H 5$. No entanto, a fim de ampliar a investigação, foram realizadas, por meio da regressão quantílica, as estimações da equação (35), a fim de analisar e testar essa hipótese. Os coeficientes de interesse obtidos com essas estimações constam no Apêndice F.

Corroborando essa expectativa, de uma maneira geral, os resultados não suportam $H 5$. Em relação à presença de investidores institucionais, não se observa qualquer padrão associativo, seja para Prob e Prob_Dif, assim como para as suas interações.

No caso da adesão aos segmentos de governança corporativa da BM\&FBovespa, os resultados não permitem uma conclusão diferente daqueles obtidos para a presença de 
investidores institucionais. Entretanto, chama atenção a ocorrência de coeficientes positivos e estatisticamente significativos para Prob x Gov observados na amostra total e nas decisões 1 e 4.

Esses resultados sugerem que as práticas de governança corporativa associadas às características analisadas não seriam efetivas no controle das DCTA. Sendo assim, o único mecanismo capaz de restringi-las seria a governança tributária, por intermédio da sensibilidade ao risco de detecção associado às $D C T$, como visto na seção anterior (5.4.5). Esse cenário oferece mais liberdade para o oportunismo gerencial, dada o menor controle interno da evasão tributária.

Entretanto, verifica-se que, para as firmas diferenciadas, a adesão àqueles segmentos de governança contribui com a probabilidade de detecção, no caso da decisão 1, pois observa-se uma associação negativa e estatisticamente significativa em Q25, Q50 e Q75, o que não havia sido observado nos resultados obtidos com a equação (33).

\subsubsection{Inter-relação entre Escolhas Contábeis Oportunistas e Ajustes Tributários Anormais}

H6: há uma inter-relação estatisticamente significativa entre as escolhas contábeis oportunistas e os ajustes tributários anormais realizados pelas firmas brasileiras de capital aberto.

O inter-relacionamento entre ESC e DCTA pode revelar aspectos de interesse para a avaliação da hipótese do feedback positivo entre as escolhas contábeis oportunistas e as estratégias de evasão tributária, uma vez que tal inter-relacionamento é uma das características desse fenômeno, o qual seria uma das principais explicações para a restrição do oportunismo gerencial em função do risco de detecção tributário.

A Tabela 19 exibe os resultados referentes aos coeficientes da variável DTCA, no caso das estimações da equação (32) (Painel A), e os coeficientes da variável ESC, para as estimações da equação (33) (Painel B) 
Tabela 19 - Resultados para DCTA - Equação (32)

Painel A

\begin{tabular}{|c|c|c|c|c|c|c|}
\hline & \multicolumn{6}{|c|}{ Coeficientes } \\
\hline & \multirow{2}{*}{$\begin{array}{c}\text { Regressão } \\
\text { com Base na } \\
\text { Média } \\
\text { Condicional } \\
\end{array}$} & \multicolumn{5}{|c|}{ Regressão Quantílica } \\
\hline & & Q05 & Q25 & Q50 & Q75 & Q95 \\
\hline Amostra Total & $0,525^{* * *}$ & $0,610^{* * *}$ & $0,383^{* * *}$ & $0,469^{* * *}$ & $0,861^{* * *}$ & $0,836^{* * *}$ \\
\hline Decisão 1 & $1,694^{*}$ & $1,079^{* * *}$ & 0,246 & $0,549^{* * *}$ & $0,984^{* * *}$ & $0,706^{* * *}$ \\
\hline Decisão 2 & 0,439 & 0,831 & $0,406^{* * *}$ & 0,167 & $-0,016$ & 0,001 \\
\hline Decisão 3 & $-0,501$ & 0,132 & 0,221 & 0,424 & $0,764^{* * *}$ & 0,527 \\
\hline Decisão 4 & 3,425 & $2,185^{* * *}$ & $0,497^{*}$ & $0,594^{* * *}$ & $0,273^{* * *}$ & 0,063 \\
\hline
\end{tabular}

As estimações da amostra total e da decisão 3 foram realizadas com o emprego dos MQO. Para as demais estratificações, foi utilizado dados em painel com efeitos fixos

Painel B - Resultados para ESC - Equação (33)

\begin{tabular}{|c|c|c|c|c|c|c|}
\hline & \multicolumn{6}{|c|}{ Coeficientes } \\
\hline & \multirow{2}{*}{$\begin{array}{c}\text { Regressão } \\
\text { com Base } \\
\text { na Média } \\
\text { Condicional }\end{array}$} & \multicolumn{5}{|c|}{ Regressão Quantílica } \\
\hline & & Q05 & Q25 & Q50 & Q75 & Q95 \\
\hline Amostra Total & 0,006 & 0,009 & 0,001 & 0,0004 & 0,004 & $0,017^{* *}$ \\
\hline Decisão 1 & 0,006 & 0,0001 & 0,00007 & 0,002 & 0,006 & $0,026^{* * *}$ \\
\hline Decisão 2 & $-0,012$ & $-0,013$ & $-0,002$ & $-0,0008$ & 0,005 & $0,013^{*}$ \\
\hline Decisão 3 & 0,0003 & 0,0006 & $-0,002$ & $-0,007$ & $-0,017^{*}$ & $0,041^{* * *}$ \\
\hline Decisão 4 & $0,008^{*}$ & $-0,001$ & 0,002 & $0,006^{* *}$ & 0,006 & 0,008 \\
\hline
\end{tabular}

A estimação da decisão 2 foi realizada por MQ2E. Para a amostra total $\mathrm{e}$ as demais decisões utilizou-se de dados em painel com efeitos aleatórios. A amostral total compreende todas as observações firmas-ano. Decisão 1 somente considera aquelas observações em que DCTA $>0$. Em Decisão 2 são consideradas apenas observações em que $E S C>0$. Para Decisão 3, as observações incluídas são aquelas em que ESC > 0 e $D C T A>0$. Já em Decisão 4, são consideradas as observações em que $E S C<0$ e $D C T A>0$.

*, ** e *** indicam a significância estatística bicaudal a 10\%,5\%; e $1 \%$, respectivamente.

Fonte: dados da pesquisa.

Para a amostra total, tanto pela média quanto ao longo dos quantis, as DCTA exibem coeficientes positivos e altamente significativos tal qual esperado (Painel A), constatações que se alinham às evidências obtidas por Piqueiras (2010) e Ferreira et al. (2012).

Esses resultados também são verificados entre as estratégias, porém não há a evidência de um padrão associativo que indique a existência de um comportamento sistemático. Aqui, também se observa que os resultados dependem da decisão.

$\mathrm{Na}$ amostra total, todos os resultados indicam que há uma relação positiva e estatisticamente significativa entre ESC e DCTA. No caso da decisão 1 (DCTA > 0), verifica-se 
que também há uma associação positiva e altamente significativa praticamente para toda distribuição de ESC. O coeficiente estimado em Q25 é a exceção. Contudo, verifica-se que a condição $D C T A>0$ não é suficiente para a manutenção dos resultados, pois, nas decisões 3 e 4, constatam-se configurações diferentes ao longo dos quantis, as quais indicam que a associação mostra-se mais forte quando $E S C<0$ (decisão 4).

Sob a decisão 4, conforme discutido na seção 3.2.4, o agente conseguiria reduzir a tributação da firma, arcando com um menor risco de detecção, bem como mitigaria os efeitos negativos sobre a sua remuneração. No entanto, como a estratégia envolve $E S C<0$, ela contempla, necessariamente, a relação entre o benefício de divulgação financeira decorrente dessa escolha e aquele gerado pela evasão tributária.

A questão que surge desse cenário é que, conforme a proposição $4 a$ (seção 3.2.4), não haveria complementaridade no caso de $E S C<0$ e $D C T A>0$, enquanto a condição dada por (17) (seção 3.2.2) fosse mantida, pois os benefícios dessas escolhas seriam mutuamente excludentes.

Sendo assim, aumentos nas DCTA somente poderiam estar associados a aumentos em $E S C$, caso o benefício obtido com $E S C<0$ não atendesse a condição dada por (17). Essa circunstância é sugerida pelos resultados, os quais podem indicar que $E S C<0$ teria sido direcionado por incentivos tributários, visando a redução do risco de detecção. Nessa situação, os aumentos nas DCTA seriam capazes de mitigar a redução na remuneração dos agentes, desde que a percepção quanto ao risco de detecção fosse suficientemente baixa, o que parece ser verdadeiro na amostra analisada, tendo em vista os demais resultados obtidos neste estudo.

Já em relação a ESC (Painel B), os resultados indicam que essa variável somente está positivamente associada a DCTA no quantil mais elevado (Q95), o que apenas não é verificado na decisão 4.

Conjuntamente, essas constatações indicam que somente há inter-relacionamento entre ESC e DCTA nos níveis mais elevados da distribuição dessas variáveis, o que apenas pode ser observado na amostra total e na decisão 1.

Por outro lado, não se pode desconsiderar que as variações de DCTA seriam capazes de explicar parcialmente as variações de ESC, o que sugere que, ao definir as escolhas contábeis oportunistas, os agentes considerariam os ajustes tributários evasivos a serem realizados. Não se trata de causalidade, mas sim de influência. 


\subsubsection{Síntese das Conclusões sobre as Hipóteses da Pesquisa}

O quadro 6 apresenta a síntese das conclusões referentes às hipóteses de pesquisa, as quais baseiam-se na análise dos resultados obtidos com as estimações das equações (32), (33), (34) e (35), apresentada nas seções 5.3.3 a 5.3.7.

Quadro 6 - Síntese das Conclusões sobre as Hipóteses da Pesquisa

\begin{tabular}{|c|c|c|}
\hline Hipóteses & Conclusões & Resumo das Constatações \\
\hline H1 & $\begin{array}{c}\text { Não } \\
\text { Rejeitada }\end{array}$ & $\begin{array}{l}\text { Foram encontradas evidências da existência de uma associação negativa } \\
\text { e estatisticamente significativa entre } P r o b \text { e } E S C \text { nas decisões teóricas } 2 \\
\text { e } 4 \text { (firmas em geral), assim como entre Prob_Dif e ESC na amostra total } \\
\text { e nas decisões } 1 \text { e } 3 \text {. }\end{array}$ \\
\hline $\mathrm{H} 2$ & $\begin{array}{c}\text { Não } \\
\text { Rejeitada }\end{array}$ & $\begin{array}{l}\text { As evidências obtidas indicam que, para as firmas em geral, a associação } \\
\text { entre Prob e } E S C \text { é mais fraca na presença de investidores institucionais, } \\
\text { somente na decisão } 4 \text {. Para as firmas diferenciadas, a associação entre } \\
\text { Prob_Dif e ESC se mostrou mais fraca na amostra total e na decisão 3, } \\
\text { quando há investidores institucionais. }\end{array}$ \\
\hline $\boldsymbol{H 3}$ & Rejeitada & $\begin{array}{l}\text { Não foram encontradas evidências de associação negativa e } \\
\text { estatisticamente significativa entre Prob e } D C T A \text {, bem como entre } \\
\text { Prob_Dif e DCTA }\end{array}$ \\
\hline H4 & $\begin{array}{c}\text { Não } \\
\text { Rejeitada }\end{array}$ & $\begin{array}{l}\text { Os resultados indicam que há uma associação negativa e } \\
\text { estatisticamente significativa, preponderante ao longo dos quantis, entre } \\
\text { Prob_Dif e } D C T \text {, tanto para a amostra total quanto para as decisões. } \\
\text { Entretanto, não foram encontradas evidências da existência de uma } \\
\text { associação negativa e estatisticamente significativa entre Prob e } D C T \text {. }\end{array}$ \\
\hline H5 & Rejeitada & $\begin{array}{l}\text { Os resultados indicam que as associações entre Prob e DCTA e entre } \\
\text { Prob_Dif e DCTA não se mostram mais fracas na presença de } \\
\text { investidores institucionais ou nos casos em que a firma aderiu aos } \\
\text { segmentos de governança corporativa da BM\&FBovespa. }\end{array}$ \\
\hline H6 & Rejeitada & $\begin{array}{l}\text { As evidências demonstram que, tanto na amostra total quanto nas } \\
\text { decisões } 1,2 \text { e } 4 \text {, há evidência de associação positiva e estatisticamente } \\
\text { significativa entre } D C T A \text { e } E S C \text {, que pode ser observada para a maioria } \\
\text { dos quantis. As variações de } D C T A \text { são capazes de explicar parcialmente } \\
\text { as variações de } E S C \text {, entretanto, os resultados não evidenciam que a } \\
\text { recíproca ocorra e, portanto, não suportam a existência de inter-relação } \\
\text { entre essas variáveis. }\end{array}$ \\
\hline
\end{tabular}

Fonte: resultados da pesquisa. 


\section{CONSIDERAÇÕES FINAIS}

Sob a estrutura teórico-analítica desenvolvida no Capítulo 3 deste trabalho, os agentes são avessos ao risco, possuem remuneração variável e arcam com o ônus, mesmo que parcial, dos custos de detecção de uma eventual evasão tributária. Eles decidem sobre as escolhas contábeis oportunistas e sobre as estratégias evasivas, enfrentando um risco de detecção tributário endógeno aos ajustes tributários realizados, bem como custos de divulgação financeira.

Em síntese, com base nessas premissas, foi demonstrado que, teoricamente, as escolhas contábeis oportunistas e as estratégias tributárias evasivas podem ser complementares e que ambas são sensíveis às variações da probabilidade de detecção tributária.

Parcialmente condizente com essas conclusões, os resultados obtidos na etapa empírica deste estudo sugerem que, no cenário brasileiro, a probabilidade de detecção tributária restringe as escolhas contábeis oportunistas, mensuradas pelas acumulações discricionárias, sobretudo nos níveis mais elevados da distribuição dessas escolhas.

Muito embora as evidências sejam condicionadas ao tipo de decisão teórica aqui formulada, essa é uma constatação importante, pois sugere que a evasão tributária permitiria que, em algumas situações, os agentes obtivessem ganhos privados por meio de escolhas contábeis oportunistas, por isso a sensibilidade à governança tributária.

Contudo, não foi possível verificar, no conjunto dos resultados, a indicação de que as escolhas contábeis oportunistas e as estratégias de evasão tributária seriam complementares. Os resultados indicam que os ajustes tributários anormais influenciam essas escolhas, sugerindo, assim, que estas poderiam ser definidas parcialmente em função de tais ajustes, porém a recíproca não foi observada.

Além disso, as evidências quanto à interação entre os mecanismos de governança corporativa e a probabilidade de detecção são muito pontuais e não corroboram aquela complementaridade. Entretanto, parte dos resultados indicou que, para algumas decisões, a interação entre aqueles dois mecanismos de controle aumentou o risco de detecção tributário, de modo que foi possível observar associações negativas com as escolhas contábeis oportunistas.

De uma maneira geral, as constatações foram mais contundentes para as firmas diferenciadas. Essas firmas demonstraram maior sensibilidade ao risco de detecção, tanto em relação às escolhas contábeis quanto aos ajustes tributários totais, o que é condizente com os pressupostos teóricos da hipótese dos custos políticos e revela a efetividade da atuação da autoridade tributária, pelos menos no que se refere à imposição de uma maior percepção de 
risco. Por outro lado, os resultados indicam que as firmas em geral aparentam perceber um baixo nível risco de detecção tributário, de modo que, provavelmente, os agentes seriam a ele indiferentes.

Desse modo, é preciso ter em mente que os resultados contrários às hipóteses de pesquisa analisadas, necessariamente, não contrariam os pressupostos teóricos aqui utilizados, dada a possibilidade de que, no cenário brasileiro, o risco de detecção tributário seria insuficiente para afetar as escolhas contábeis oportunistas de forma generalizada. Trata-se de uma constatação eminentemente empírica e que pode ser útil na avaliação da política fiscalizatória tributária estatal, assim como contribuir com ações que levem ao seu aprimoramento.

Dentre as contribuições que este trabalho oferece à literatura, é possível destacar:

a) a discussão apresentada no referencial teórico, uma vez que reúne e inter-relaciona hipóteses teóricas e resultados empíricos, bem como os principais aspectos que gravitam em torno da temática que trata da evasão tributária da firma em um contexto de agência;

b) a estrutura teórico-analítica desenvolvida no Capítulo 3, a qual permite formular inúmeras hipóteses de pesquisa, além das aqui analisadas, oferecendo, assim, interessantes avenidas de pesquisas teóricas ou empíricas;

c) os resultados obtidos na etapa empírica, tendo em vista que há a indicação de que as escolhas contábeis oportunistas interagem com a dimensão tributária e podem ser afetadas pela atuação da autoridade tributária, sugerindo que os incentivos ou restrições advindos daquela dimensão seriam importantes para a decisão dos agentes e podem contribuir com a compreensão daquelas escolhas;

d) a discussão acerca da definição da expressão evasão tributária (Apêndice A), a qual tangencia aspectos do cenário brasileiro, pois contribui com a redução da imprecisão semântica existente na literatura.

A etapa empírica do trabalho sofreu severas restrições em razão da limitação da base de dados, inclusive no que se refere ao tamanho da amostra. A não disponibilidade pública de informações de interesse, tais como, a indicação das firmas sujeitas ao acompanhamento diferenciado e a daquelas que foram objeto de auditoria tributária no período analisado, é um agravante.

Em relação à probabilidade de detecção, a disponibilidade de dados anuais e setoriais ou, no caso das firmas diferenciadas, de dados anuais, prejudicou a realização de uma investigação mais próxima daquilo que poderia representar a percepção de risco dos agentes. 
Taxas médias de auditoria, apesar de intuitivas, são proxies muito precárias para refletir essa percepção, ainda mais se possuem categorização limitada, como as utilizadas nesta pesquisa. Entretanto, as evidências obtidas indicam que essas taxas aparentam refletir, mesmo que parcialmente, a percepção de risco dos agentes.

Uma limitação importante refere-se à mensuração da evasão tributária. A proxy utilizada, DCTA, é uma estimativa do que seria a parcela anormal das $D C T$. O problema é que, além dessa proxy ser uma estimativa sujeita a erros de mensuração, bem como só considerar ajustes sem conformidade contábil-tributária, não é possível identificar a parcela que teria sido considerada ilegal pelos agentes, caso tal parcela tenha existido.

Apesar disso, a associação positiva e significativa verificada entre as DCTA e as escolhas contábeis oportunistas, pode ser assumida como uma indicação da qualidade dessa proxy. Outrossim, a sensibilidade das DCT à probabilidade de detecção revela que essas diferenças podem conter ajustes ilegais e, consequentemente, é muito provável que as DCTA também expressem esses ajustes.

Outra limitação da pesquisa se deve a não utilização de proxies adicionais para as escolhas contábeis oportunistas e as estratégias de evasão tributária, o que permitiria avaliar com maior segurança a robustez dos resultados obtidos. Contudo, dada a metodologia empregada, na qual foram utilizados 4 modelos, estimados por 2 técnicas econométricas, para 5 estratificações amostrais distintas (amostra total e decisões teóricas), a inclusão de proxies adicionais resultaria um volume de informações excessivo para um único trabalho.

Entretanto, dado o caráter inovador e inédito da pesquisa, tem-se que a investigação realizada também representou uma incursão exploratória no cenário nacional, de modo que remanescem inúmeras oportunidades de pesquisa, seja para aprimorar o que foi proposto nesta tese, seja para investigar aspectos adicionais, por exemplo:

a) aprimorar a estrutura teórico-analítica, a fim de incorporar a interação com decisões de períodos anteriores, bem como incorporar de forma mais efetiva e explícita os efeitos dos mecanismos de governança tributária

b) aprimorar a proxy para probabilidade de detecção, no sentido de torná-la endógena ao tamanho e aos ajustes tributários da firma;

c) investigar a interação entre probabilidade de detecção e outras proxies para as escolhas contábeis oportunistas

d) investigar a interação entre a probabilidade de detecção e outras variáveis indicativas de boas práticas de governança corporativa; 
e) avaliar os efeitos da probabilidade de detecção sobre os planos de compensação de remuneração variável, bem como a interação entre incentivos remuneratórios, evasão tributária e probabilidade de detecção;

f) avaliar se o mercado enxerga a probabilidade de detecção tributária como um mecanismo de governança que reduz o oportunismo gerencial;

g) investigar a relação entre probabilidade de detecção, escolhas contábeis específicas e ajustes tributários também específicos;

h) avaliar o efeito da reversão das acumulações discricionárias e dos ajustes tributários temporários.

Por fim, espera-se que estas, bem como tantas outras avenidas de pesquisa relacionadas ao tema aqui investigado, sejam exploradas e, assim, seja possível construir e consolidar uma linha científica de estudos que inclua, de forma permanente, a temática tributária na agenda da pesquisa em contabilidade no Brasil. 


\section{REFERÊNCIAS}

ALLINGHAM, M. G.; SANDMO, A. Income Tax Evasion: A theoretical analysis. Journal of Public Economics, v.1, p. 323-328, 1972.

ALM, J. Tax Compliance and Administration. In: HILDRETH, W. B.; RICHARDSON, J. A. Handbook on Taxation. New York: Marcel Dekker, p.741-768, 1999.

AL-MOUSAWI, R. J.; AL-THUNEIBAT, A. The Effect of Audit Quality on the Earnings Management Activities. Dirasat, Administrative Sciences, v. 38, n. 2, p. 614-628, 2011.

ANCIŪTĖ, A.; KROPIENĖ, R. The Model of Tax Evasion, Its Corrections and Coherence to the Practical Tax Administration. Ekonomika, v 89, n. 4, p.49-65, 2010

ANDREONI, J.; ERARD, B.; FEINSTEIN, J. Tax Compliance. Journal of Economic Literature, v 36, issue 2, p. 818-860, 1998

ARIAS, R. J. A Note on Indirect Tax Evasion. Universidad de la Plata, Argentina, Working Paper, 2005. Disponível em: 〈http://www.aaep.org.ar/anales/works/ works2005/arias.pdf> Acesso em: 04 ago. 2015.

ARMSTRONG, C. S.; BLOUIN, J. L.; LARCKER, David F. The Incentives for Tax Planning. Journal of Accounting and Economics, v. 53, p. 391-411, 2012.

.;___ _ JAGOLINZERB, A. D.; LARCKERC, D. F. Corporate governance, incentives, and tax avoidance. Journal of Accounting and Economics, v. 60, issue 1, p. 1$17,2015$.

ATWOOD, T. J.; DRAKE, M. S.; MYERS, J. N.; MYERS, L. A. Home Country Tax System Characteristics and Corporate Tax Avoidance: International Evidence. The Accounting Review, v. 87, n. 6, p. 1831-1860, 2012

ATTWOOD, T. J.; OMER, T. C.; SHELLEY. Before-tax versus after-tax earnings as performance measures in compensation contracts. Managerial Finance, v. 24, issue 11, p. 29 $-43,1998$.

AZEVEDO, F. B.; COSTA, F. M. Efeito da Troca da Firma de Auditoria no Gerenciamento de Resultados das Companhias Abertas Brasileiras. Revista de Administração da Mackenzie, v. 13, n. 5, p. 65-100, 2012. 
BADERTSCHER, B. A.; PHILLIPS, J. D.; PINCUS, M.; REGO, S. O. Earnings

Management Strategies and the Trade-Off between Tax Benefits and Detection Risk: to conform or no conform? The Accounting Review, v. 84, n.1, p.63-97, 2009.

BAME-ALDRED, C. W.; CULLEN, J. B.; MARTIN K. D.; PARBOTEEAH, K. P.. National Culture and Firm-Level Tax Evasion. Journal of Business Research, v. 66, issue 3, p. 390396, 2013.

BĂTRÂNCEA, L. M.; NICHITA, R. A.; BĂTRÂNCEA, I.; MOLD’OVAN, B. A. Tax Compliance Models: From Economic to Behavioral Approaches. Transylvanian Review of Administrative Sciences, n. 36, p. 13-26, 2012

BARROS, C. M.; SOARES, R. O.; LIMA, G. A. S. F. A relação entre governança corporativa e gerenciamento de resultados em empresas brasileiras. Revista de Contabilidade e Organizações, v. 7, n. 19, p. 28-39, 2013.

BAYER, R.; COWELL, F. Tax Compliance and Firm's Strategic Interdependence. Journal of Public Economics, v. 93, issues 11-12, p. 1131-1143, 2009.

BECKER, C. L.; DEFOND, M. L.; JIAMBALVO, J.; SUBRAMANYAM, K. R. The Effect of Audit Quality on Earnings Management. Contemporary Accounting Research, v. 15, issue 1, p. 1-24, 1998.

BERNASCONI, M. Tax Evasion and Orders Risk Aversion. Journal of Public Economics, 67, p.123-13, 1998

BIRSKYTE, L. Effects of Tax Auditing: does Deterrent Deter? Research Journal of Economics, Business and ICT, v.8, issue 2, 2013 p.1-8

BOUSSAIDI, A.; HAMED, M. S. The Impact of Governance Mechanisms on Tax Aggressiveness: Empirical Evidence from Tunisian Context. Asian Economic and Social Society, v. 5, n. 1, p. 1-12, 2015

BOYNTON, C. E.; DOBBINS, P. S.; PLESKO, G. A. Earnings Management and the Corporate Alternative Minimum Tax. Journal of Accounting Research, v. 30, issue Studies on Accounting and Taxation, p. 131-153, 1992.

BRASIL. Código Civil. Lei no 10.406 , de 10 de janeiro de 2002. Institui o Código Civil. Disponível em: < http://www.planalto.gov.br/ccivil_03/leis/2002/L10406.htm>. Acesso em: 10 out. 2015. 
Código Tributário Nacional (CTN). Lei no 5.172, de 25 de outubro de 1966.

Dispõe sobre o Sistema Tributário Nacional e institui normas gerais de direito tributário aplicáveis à União, Estados e Municípios. Disponível em: <http://www.planalto.gov.br/ ccivil_03/Leis/L5172.htm>. Acesso em: 10 out. 2015.

COMITÊ DE PRONUNCIAMENTOS CONTÁBEIS (CPC). Pronunciamento Técnico 32 - Tributos sobre o Lucro. Disponível em: < http://static.cpc.mediagroup. com.br/Documentos/340_CPC_32_rev\%2004.pdf>. Acesso em: 18/12/2015.

Decreto $n^{\circ}$ 6.022, de 22 de janeiro de 2007. Institui o Sistema Público de Escrituração Digital - Sped. Disponível em: < http://www.planalto.gov.br/ccivil_03/ _ato2007-2010/2007/Decreto/D6022.htm>. Acesso em: 10 out. 2015.

Lei das Sociedades Anônimas. Lei no 6.404, de 15 de dezembro de 1976. Dispõe sobre as Sociedades por Ações. Disponível em: < http://www.planalto.gov.br/ ccivil_03/LEIS/L6404consol.htm>. Acesso em: 10 out. 2015.

Lei $\mathrm{n}^{\circ}$ 4.502, de 30 de novembro de 1964. Dispõe Sôbre o Impôsto de Consumo e reorganiza a Diretoria de Rendas Internas. Disponível em: < http://www.planalto.gov.br/ CCIVIL_03/leis/L4502.htm>. Acesso em: 10 out. 2015.

Lei $\mathrm{n}^{\circ}$ 8.137, de 27 de dezembro de 1990. Define crimes contra a ordem tributária, econômica e contra as relações de consumo, e dá outras providências. Disponível em: < http://www.planalto.gov.br/ccivil_03/leis/L8137.htm>. Acesso em: 15 nov. 2015.

Lei n ${ }^{\circ}$ 9.430, de 27 de dezembro de 1996. Dispõe sobre a legislação tributária federal, as contribuições para a seguridade social, o processo administrativo de consulta e dá outras providências. Disponível em: < http://www.planalto.gov.br/ ccivil_03/LEIS/L9430.htm>. Acesso em: 10 out. 2015.

Lei $\mathrm{n}^{\circ}$ 10.931, de 02 de agosto de 2004. Dispõe sobre o patrimônio de afetação de incorporações imobiliárias, Letra de Crédito Imobiliário, Cédula de Crédito Imobiliário, Cédula de Crédito Bancário, altera o Decreto-Lei no 911, de 1ํ de outubro de 1969, as Leis n-4.591, de 16 de dezembro de 1964, no 4.728, de 14 de julho de 1965, e n⿳0 10.406, de 10 de janeiro de 2002, e dá outras providências. Disponível em: < http://www.planalto.gov.br/ ccivil_03/_ato2004-2006/2004/lei/110.931.htm>. Acesso em: 15 nov. 2015.

Lei no 11.196 , de 21 de novembro de 2005. Institui o Regime Especial de Tributação para a Plataforma de Exportação de Serviços de Tecnologia da Informação - REPES, o Regime Especial de Aquisição de Bens de Capital para Empresas Exportadoras - RECAP e o Programa de Inclusão Digital; dispõe sobre incentivos fiscais para a inovação tecnológica;

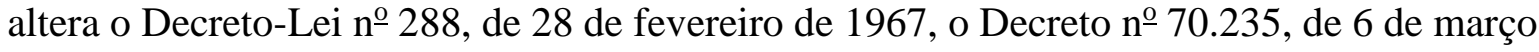


de 1972, o Decreto-Lei no 2.287, de 23 de julho de 1986, as Leis nos 4.502, de 30 de novembro de 1964, 8.212, de 24 de julho de 1991, 8.245, de 18 de outubro de 1991, 8.387, de 30 de dezembro de 1991, 8.666, de 21 de junho de 1993, 8.981, de 20 de janeiro de 1995 , 8.987, de 13 de fevereiro de 1995, 8.989, de 24 de fevereiro de 1995, 9.249, de 26 de dezembro de 1995, 9.250, de 26 de dezembro de 1995, 9.311, de 24 de outubro de 1996, 9.317, de 5 de dezembro de 1996, 9.430, de 27 de dezembro de 1996, 9.718, de 27 de novembro de 1998, 10.336, de 19 de dezembro de 2001, 10.438, de 26 de abril de 2002, 10.485 , de 3 de julho de 2002, 10.637, de 30 de dezembro de 2002, 10.755, de 3 de novembro de 2003, 10.833, de 29 de dezembro de 2003, 10.865, de 30 de abril de 2004, 10.925, de 23 de julho de 2004, 10.931, de 2 de agosto de 2004, 11.033, de 21 de dezembro de 2004, 11.051, de 29 de dezembro de 2004, 11.053, de 29 de dezembro de 2004, 11.101, de 9 de fevereiro de 2005, 11.128, de 28 de junho de 2005, e a Medida Provisória no ${ }^{\circ} .199-14$, de 24 de agosto de 2001; revoga a Lei $\mathrm{n}^{\mathrm{o}} 8.661$, de 2 de junho de 1993, e dispositivos das Leis $\mathrm{n}^{\mathrm{os}} 8.668$, de 25 de junho de 1993, 8.981, de 20 de janeiro de 1995, 10.637, de 30 de dezembro de 2002, 10.755, de 3 de novembro de 2003, 10.865, de 30 de abril de 2004, 10.931, de 2 de agosto de 2004, e da Medida Provisória no2.158-35, de 24 de agosto de 2001; e dá outras providências.

Disponível em: < http://www.planalto.gov.br/ccivil_03/_ato2004-2006/2005/lei/111196.htm>. Acesso em: 10 out. 2015.

Lei $n^{\circ} 11.774$, de 17 de setembro de 2008. Altera a legislação tributária federal, modificando as Leis n $\underline{\text { os }} 10.865$, de 30 de abril de 2004, 11.196, de 21 de novembro de 2005, 11.033, de 21 de dezembro de 2004, 11.484, de 31 de maio de 2007, 8.850, de 28 de janeiro de 1994, 8.383, de 30 de dezembro de 1991, 9.481, de 13 de agosto de 1997, 11.051, de 29 de dezembro de 2004, 9.493, de 10 de setembro de 1997, 10.925, de 23 de julho de 2004; e dá outras providências. Disponível em: < http://www.planalto.gov.br/ccivil_03/_ato20072010/2008/lei/L11774.htm>. Acesso em: 10 out. 2015.

Lei no 11.941 , de 27 de maio de 2009. Altera a legislação tributária federal relativa ao parcelamento ordinário de débitos tributários; concede remissão nos casos em que especifica; institui regime tributário de transição, alterando o Decreto $\mathrm{n}^{\mathrm{o}} 70.235$, de 6 de março de 1972, as Leis $\mathrm{n}^{\text {os }} 8.212$, de 24 de julho de 1991, 8.213, de 24 de julho de 1991, 8.218, de 29 de agosto de 1991, 9.249, de 26 de dezembro de 1995, 9.430, de 27 de dezembro de 1996, 9.469, de 10 de julho de 1997, 9.532, de 10 de dezembro de 1997, 10.426, de 24 de abril de 2002, 10.480 , de 2 de julho de 2002, 10.522, de 19 de julho de 2002, 10.887, de 18 de junho de 2004, e 6.404, de 15 de dezembro de 1976, o Decreto-Lei n- 1.598 , de 26 de dezembro de 1977, e as Leis n $\stackrel{\text { os }}{8.981, ~ d e ~} 20$ de janeiro de 1995, 10.925, de 23 de julho de 2004, 10.637, de 30 de dezembro de 2002, 10.833, de 29 de dezembro de 2003, 11.116, de 18 de maio de 2005, 11.732, de 30 de junho de 2008, 10.260, de 12 de julho de 2001, 9.873, de 23 de novembro de 1999, 11.171, de 2 de setembro de 2005, 11.345, de 14 de setembro de 2006; prorroga a vigência da Lei no 8.989, de 24 de fevereiro de 1995; revoga dispositivos das Leis $\mathrm{n}^{\mathrm{os}}$ 8.383, de 30 de dezembro de 1991, e 8.620, de 5 de janeiro de 1993, do Decreto-Lei no 73, de 21 de novembro de 1966, das Leis nos 10.190 , de 14 de fevereiro de 2001, 9.718, de 27 de novembro de 1998, e 6.938, de 31 de agosto de 1981, 9.964, de 10 de abril de 2000, e, a partir da instalação do Conselho Administrativo de Recursos Fiscais, os Decretos n ${ }^{\text {os }}$ 83.304, de 28 de março de 1979, e 89.892, de 2 de julho de 1984, e o art. 112 da Lei no 11.196 , de 21 de novembro de 2005; e dá outras providências. Disponível em: < http://www.planalto.gov.br/ ccivil_03/_ato2007-2010/2009/lei/111941.htm>. Acesso em: 15 nov. 2015. 
Lei de Acesso à Informação. Lei no 12.527 , de 18 de novembro de 2011. Regula o acesso a informações previsto no inciso XXXIII do art. $5^{\circ}$, no inciso II do $\S 3^{\circ}$ do art. 37 e no $\S 2^{\circ}$ do art. 216 da Constituição Federal; altera a Lei $\mathrm{n}^{\mathrm{o}}$ 8.112, de 11 de dezembro de 1990; revoga a Lei $\mathrm{n}^{\mathrm{o}}$ 11.111, de 5 de maio de 2005, e dispositivos da Lei $\mathrm{n}^{\mathrm{o}}$ 8.159, de 8 de janeiro de 1991; e dá outras providências. Disponível em: < http://www.planalto.gov.br/ccivil_03/ _ato2011-2014/2011/lei/112527.htm>. Acesso em: 20 ago. 2015.

Lei $\mathrm{n}^{\circ} 12.973$, de 13 de maio de 2014. Altera a legislação tributária federal relativa ao Imposto sobre a Renda das Pessoas Jurídicas - IRPJ, à Contribuição Social sobre o Lucro Líquido - CSLL, à Contribuição para o PIS/Pasep e à Contribuição para o Financiamento da Seguridade Social - Cofins; revoga o Regime Tributário de Transição - RTT, instituído pela Lei $\mathrm{n}^{\mathrm{o}}$ 11.941, de 27 de maio de 2009; dispõe sobre a tributação da pessoa jurídica domiciliada no Brasil, com relação ao acréscimo patrimonial decorrente de participação em lucros auferidos no exterior por controladas e coligadas; altera o Decreto-Lei $n^{-0}$ 1.598, de 26 de dezembro de 1977 e as Leis n ${ }^{\text {os }}$ 9.430, de 27 de dezembro de 1996, 9.249, de 26 de dezembro de 1995, 8.981, de 20 de janeiro de 1995, 4.506, de 30 de novembro de 1964 , 7.689, de 15 de dezembro de 1988, 9.718, de 27 de novembro de 1998, 10.865, de 30 de abril de 2004, 10.637, de 30 de dezembro de 2002, 10.833, de 29 de dezembro de 2003, 12.865, de 9 de outubro de 2013, 9.532, de 10 de dezembro de 1997, 9.656, de 3 de junho de 1998, 9.826, de 23 de agosto de 1999, 10.485, de 3 de julho de 2002, 10.893, de 13 de julho de $2004,11.312$, de 27 de junho de 2006, 11.941, de 27 de maio de 2009, 12.249, de 11 de junho de 2010, 12.431, de 24 de junho de 2011, 12.716, de 21 de setembro de 2012, e 12.844, de 19 de julho de 2013; e dá outras providências. Disponível em: < http://www.planalto.gov.br/ ccivil_03/_ato2011-2014/2014/Lei/L12973.htm>. Acesso em: 15 nov. 2015.

Medida Provisória no 449, de 3 de dezembro de 2008. Altera a legislação tributária federal relativa ao parcelamento ordinário de débitos tributários, concede remissão nos casos em que especifica, institui regime tributário de transição, e dá outras providências, Disponível em: < http://www.planalto.gov.br/ccivil_03/_ato2007-2010/2008/mpv/449.htm >. Acesso em: 15 nov. 2015.

MINISTÉRIO DA FAZENDA. Regimento Interno da RFB. Portaria MF nº 203, de 14 de maio de 2012. Aprova o Regimento Interno da Secretaria da Receita Federal do Brasil RFB. Disponível em: < http://normas.receita.fazenda.gov.br/ sijut2consulta/ link.action?visao=anotado\&idAto=37965> . Acesso em: 15 nov. 2015.

Regulamento do Imposto de Renda (RIR/99). Decreto n ${ }^{\circ} 3.000$, de 26 de março de 1999. Regulamenta a tributação, fiscalização, arrecadação e administração do Imposto sobre a Renda e Proventos de Qualquer Natureza. Disponível em: < http://www.planalto.gov.br/ ccivil_03/decreto/d3000.htm>. Acesso em: 10 out. 2015.

SECRETARIA DA RECEITA FEDERAL DO BRASIL (RFB). Portaria RFB $\mathrm{n}^{\circ}$ 2.923, de 16 de dezembro de 2009. Estabelece parâmetros para seleção das pessoas jurídicas a serem submetidas a acompanhamento econômico-tributário diferenciado e especial no ano de 
2010, e dá outras providências. Disponível em: < http://normas.receita.fazenda.gov.br/ sijut2consulta/link.action?visao=anotado\& idAto=30628>. Acesso em: 22 nov. 2015.

SECRETARIA DA RECEITA FEDERAL DO BRASIL (RFB). Portaria RFB n

2.357, de 14 de dezembro de 2010. Estabelece parâmetros para seleção das pessoas jurídicas a serem submetidas a acompanhamento econômico-tributário diferenciado e especial no ano de 2011, e dá outras providências. Disponível em: < http://normas.receita.fazenda.gov.br/ sijut2consulta/link.action?visao=anotado\& idAto=30555\#271005>. Acesso em: 22 nov. 2015.

SECRETARIA DA RECEITA FEDERAL DO BRASIL (RFB). Portaria RFB n ${ }^{\circ}$ 3.778 , de 20 de dezembro de 2011. Estabelece parâmetros para a indicação das pessoas jurídicas a serem submetidas a acompanhamento econômico-tributário diferenciado e especial no ano de 2012, e dá outras providências. Disponível em: < http://normas.receita.fazenda. gov.br/sijut2consulta/link.action?visao=anotado\& idAto=37056\#939451>. Acesso em: 22 nov. 2015.

SECRETARIA DA RECEITA FEDERAL DO BRASIL (RFB). Portaria RFB n ${ }^{\circ}$ 2.563 , de 19 de dezembro de 2012. Estabelece parâmetros para a indicação das pessoas jurídicas a serem submetidas a acompanhamento econômico-tributário diferenciado e especial no ano de 2013, e dá outras providências. Disponível em: < http://normas.receita.fazenda. gov.br/sijut2consulta/link.action?visao=anotado\& idAto=39171\#1257380>. Acesso em: 22 nov. 2015.

.SECRETARIA DA RECEITA FEDERAL DO BRASIL (RFB). Resultado da Fiscalização no ano de 2011, 2012. Disponível em: <http://idg.receita.fazenda.gov.br/ dados/resultados/fiscalizacao/arquivos-e-imagens/ resultadofiscalizacao2011.pdf >. Acesso em: 05 out. 2015.

SECRETARIA DA RECEITA FEDERAL DO BRASIL (RFB). Resultado da Fiscalização no ano de 2012, 2013. Disponível em: <http://idg.receita.fazenda.gov.br/ dados/resultados/fiscalizacao/arquivos-e-imagens/ resultadofiscalizacao2012.pdf $>$. Acesso em: 05 out. 2015.

. SECRETARIA DA RECEITA FEDERAL DO BRASIL (RFB). Resultado da Fiscalização no ano de 2013, 2014. Disponível em: < http://idg.receita.fazenda.gov.br/ dados/resultados/fiscalizacao/arquivos-e-imagens/resultadofiscalizacao2013.pdf > . Acesso em: 05. out. 2015.

SECRETARIA DA RECEITA FEDERAL DO BRASIL (RFB). Plano Anual de Fiscalização da Receita Federal do Brasil para 2015 e Resultados de 2014, 2015 a. Disponível em: < http://idg.receita.fazenda.gov.br/dados/resultados/fiscalizacao/arquivos -eimagens/2015_03_05-plano-anual-da-fiscalizacao-2015-e-resultados-2014.pdf >. Acesso em: 05 out. 2015. 
SECRETARIA DA RECEITA FEDERAL DO BRASIL (RFB). Resultados da Fiscalização $1^{\circ}$ Semestre de 2015, 2015b. Disponível em: < http://idg.receita.fazenda. gov.br/orientacao/tributaria/auditoria-fiscal/sufis-nota-a-imprensa-resultados-2015-1osemestre-v-final2.pdf>. Acesso em: 05 out. 2015.

SECRETARIA DA RECEITA FEDERAL DO BRASIL (RFB). Relatório Dados

Setoriais 2009/2013, 2015. Disponível em <http://idg.receita.fazenda.gov.br/ dados/receitadata/estudos-e-tributarios-e-aduaneiros/estudos-e-estatisticas/estudos-diver sos/dados-setoriais-2009-2013.pdf>. Acesso em: 05 out. 2015.

BROOKS, C. Introductory Econometric for Finance, 2 ed. Cambridge: Cambridge University Press, 2008.

CABELlO, O. G. Análise dos Efeitos das Práticas de Tributação do Lucro na Effective Tax Rate (ETR) das Companhias Abertas Brasileiras: Uma Abordagem da Teoria das Escolhas Contábeis. Tese (Doutorado em Ciências Contábeis) - Programa de Pós-Graduação em Ciências Contábeis, Departamento de Contabilidade e Atuária, Faculdade de Economia, Administração e Contabilidade da Universidade de São Paulo, 2012.

CAMERER, C. F.; HO, T. H. Violations of the betweenness axiom and nonlinearity in probability. Journal of Risk and Uncertainty, v. 8, p. 167-196, 1994.

CAMERON, A. COLIN; TRIVEDI, Pravin K. Microeconometrics Using Stata. Texas: Stata Press, 2009.

CHEN, K. P.; CHU, C. Y. C. Internal Control vs external Manipulation: A Model of Corporate Income Tax Evasion. RAND Journal of Economics, v. 36, p. 151-164, 2005.

CHEN, S. et al. Are family firms more tax aggressive than non-family firms? Journal of Financial Economics, v. 95, issue 1, p. 41-61, 2010.

CHOI, W. W.; LEE, H. A. Management of Accrual Components in Response to Corporate Income Tax Rate Changes: Evidence from Korea. The Journal of Applied Business Research, v. 29, n. 5, p. 1421-1436, 2013.

CLOYD, C. B. The Effects of Financial Accounting Conformity on Recommendations of Tax Preparers. Journal of American Taxation Association, v. 17, Issue 2, p. 50-70, 1995. 
.; PRATT, J.; STOCK, T. The Use of Financial Accounting Choice to Support

Aggressive Tax Positions: Public and Private Firms. Journal of Accounting Research, v. 34, n. 1, p.23-43, 1996.

COSTA, P. S. Implicações da Adoção das IFRS sobre a Conformidade Financeira e Fiscal das Companhias Abertas Brasileiras. Tese (Doutorado em Ciências Contábeis) Programa de Pós-Graduação em Ciências Contábeis, Departamento de Contabilidade e Atuária, Faculdade de Economia, Administração e Contabilidade da Universidade de São Paulo, 2012.

CROCKER, K. J.; SLEMROD, J. Corporate Tax Evasion with Agency Costs. Journal of Public Economics, v 89, n 9, p 1593-1610, 2005

DeBACKER, J. M. et al. Legal Enforcement and Corporate Behavior: An Analysis of Tax Aggressiveness after an Audit. The Journal of Law \& Economics, v. 58, n. 2, p. 291-324, 2015.

DECHOW, P. M.; SLOAN, R. G.; SWEENEY, A. P. Detecting Earnings Management. The Accounting Review, v. 70, n. 2, p. 193 - 225, 1995.

.; DICHEV, I. D. The Quality of Accruals and Earnings: The Role of Accrual Estimation Errors. The Accounting Review, v. 77, supplement, p. 35-59, 2002.

et al. Detecting Earnings Management: A New Approach. Journal of Accounting Research, v. 50, n. 2, p. 275-334, 2012.

DESAI, M. A.; DHARMAPALA, D. Corporate Tax Avoidance and High Powered Incentives. Journal of Financial Economics, v.79, p. 145-179, 2006a.

; DYCK, A.; ZINGALES, L. Theft and Taxes. Journal of Financial Economics, v. 84, p.591-623, 2007

.; DHARMAPALA, D. Taxation and Corporative Governance: An Economic Approach, in: Drexl, J., Hilty, R. M., Schön, W., Straus, J. ed., Tax and Corporate Governance, MPI Studies on Intellectual Property, Competition and Tax Lax, volume 3 (Springer, 2008), p. 13-30, 2008.

;_ Corporate Tax Avoidance and Firm Value. Review of Economics and Statistics, v. 91, n 3, p. 537-546, 2009a. 
Earnings Management, Corporate Tax Shelters, and Book-Tax Alignment.

National Tax Journal, v. LXII, n. 1, p. 169-186, 2009b.

DHALIWAL, D. S.; GLEASON, C. A.; MILLS, L. F. Last-Chance Earnings Management: Using the Tax Expense to Meet Analyst's Forecasts. Contemporary Accounting Research, v. 21, n. 2, p 431-459, 2004.

DYRENG, S. D.; HANLON, M.; MAYDEW, E. L. Long-Run Corporate Tax Avoidance. The Accounting Review, v. 83, n. 1, p. 61-82, 2008.

.; ___ The Effects of Executives on Corporate Tax Avoidance. The

Accounting Review, v. 85, n. 4, p. 1163-1189, 2010.

EL GHOUL, S.; GUEDHAMI, O.; PITTMAN, J. The Role of IRS Monitoring in Equity Pricing in Public Firms. Contemporary Accounting Research, v. 28, issue 2 p 643-674, 2011

ERICKSON, M.; HANLON, M.; MAYDEW, E. L. How Much Will Firms Pay for Earnings that do not Exist? Evidence of tax paid on allegedly fraudulent earnings. The Accounting Review, v. 79, n. 2, p. $387-408,2004$.

; HEITZMAN, S. M.; ZHANG, X. F. Tax-Motivated Loss Shifting. The Accounting

Review, v. 88, n. 5, p. 1657-1682, 2013

EUROPEAN COMMISSION. Compliance Risk Management Guide for Tax

Administrations, 2010. Disponível em: http://ec.europa.eu/taxation_customs/ common/publications/info_docs/taxation/index_en.htm. Acesso em: 09 out. 2015.

FERREIRA, F. R. et al. Book-Tax Differences e Gerenciamento de Resultados no Mercado de Ações do Brasil. RAE, v. 52, n. 5, p. 488-502, 2012.

FERRI, M. S.; SOARES, R. O. Investidores Institucionais e o Foco no Curto Prazo: um Estudo nas Empresas Negociadas na Bovespa. Revista Contabilidade Vista \& Revista, v. 20, n. 4, p. 15-30, 2009.

FIELDS, T. D.; LYS, T. Z.; VINCENT, L. Empirical Research on Accounting Choice. Journal of Accounting and Economics, v. 31, p. 255-307, 2001. 
FORMIGONI, H.; ANTUNES, M. T. P.; PAULO, E. Diferença entre o Lucro Contábil e Lucro Tributável: Análise sobre o gerenciamento de resultados contábeis e gerenciamento tributário nas companhias abertas brasileiras. BBR Brazilian Business Review, v. 6, n. 1, p. $44-61,2009$.

et al. Estudo sobre os Incentivos Tributários para o Gerenciamento de Resultados Contábeis nas Companhias Abertas Brasileiras. BASE - Revista de Administração e Contabilidade da Unisinos, v. 9, n. 1, p. 41 - 52, 2012.

FRANK, M. M.; LYNCH, L. J.; REGO, S. O. Tax Reporting Aggressiveness and Its Relation to Aggressive Financial Reporting. The Accounting Review, v. 84, n. 2, p. 467-496, 2009.

FRANZONI, L. A. Tax evasion and tax compliance. Working Paper n. 6.020, University of Bolonha, Italy, 1999.

FUKOFUKA, P. The Contextual Framework of Corporate Income Tax Evasion. Journal of Accounting and Taxation, v. 5, n. 2, p. 27-37, 2013.

GAERTNER, F. B. CEO After-Tax Compensation Incentives and Corporate Tax Avoidance. Contemporary Accounting Research, v. 31, issue 4, p. 1077-1102, 2014.

GARBARINO, C. Aggressive Tax Strategies and Corporate Tax Governanca: An Institutional Approach. Working Paper Case n⿳0 188/08, Bocconi School of Management, 2008.

Disponível em: <http://ssrn.com/abstract=1428772>. Acesso em: 31 ago. 2015.

GOERKE, L. Tax Overpayments, Tax Evasion, and Book-Tax Differences. CESifo Working Paper Serie No. 2212. Disponível em: 〈http://ssrn.com/abstract=1090848 〉. Acesso em: 01 out. 2015.

GOH, B. W. et al. The Effect of Corporate Tax Avoidance on the Cost of Equity. Singapore Management University School of Accountancy Research Paper No. 2014-11. Disponível em: <http://ssrn.com/abstract=2237742> Acesso em: 01 out. 2015.

GONDIM, J. L. The Tax Compliance Game with Some Evasion-Averse Taxpayers. Artigo não publicado. Disponível em: <https://editorialexpress.com/cgi-bin/ conference/download.cgi?db_name=IIPF66\&paper_id=212 . Acesso em: 08 ago. 2015

GRAETZ, M. J.; REINGANUM, J. F.; WILDE, L. L. The Tax Compliance Game: Toward an Interactive Theory of Law Enforcement. Journal of Law, Economics and Organization, v. 2, n. 1, p. 1-32, 1986. 
GRAHAM, J. R. et al. Incentives for Tax Planning and Avoidance: Evidence from the Field. The Accounting Review, v. 89, n. 3, p. 991-1023, 2014.

GUEDHAMI, O.; PITTMAN, J. The Importance of IRS Monitoring to debt Pricing in Private Firms. Journal of Financial Economics, v. 90, n. 1, p. 38-58, 2008

GUENTHER, D. A. Earnings Management in Response to Corporate Tax Rate Changes: Evidence from the 1986 Tax Reform Act. The Accounting Review, 69, n. 1, p. 230-243, 1994.

.; MATSUNAGA, S. R.; WILLIAMS, B. M. Tax Avoidance and Firm Risk.

Disponível em: <http://ssrn.com/abstract=2153187>. Acesso em: 05 out. 2015.

GUPTA, S.; NEWBERRY, K. Determinants of the Variability in Corporate Effective Tax

Rates: Evidence from Longitudinal Data. Journal of Accounting and Public Policy, v. 16, p. 1-34, 1997.

.; LAUX, R. C.; LYNCH, D. P. Do Firms Use Tax Reserves to Meet Analysts'

Forecasts? Evidence from the Pre- and Post-FIN 48 Periods. Contemporary Accounting

Research, (versão de registro on-line), Novembro/2015.

HAIR JR., J. F. et al. Análise Multivariada de Dados, 5 ed. Porto Alegre: Bookman, 2005.

HANLON, M.; MILLS, L. F.; SLEMROD, J. B. An Empirical Examination of Corporate Tax Noncompliance. Ross School of Business Paper No. 1025, 2005. Disponível em:

<http://ssrn.com/abstract=891226>. Acesso em: 02 nov. 2015.

; HEITZMAN, S. A Review of Tax Research. Journal of Accounting and

Economics, v. 50, n. 2-3, p. $127-178,2010$.

; HOOPES, J. L.; SHROFF, N. The Effect of Tax Authority Monitoring and Enforcement on Financial Reporting Quality. The Journal of the American Taxation Association, v. 36, n. 2, p. 137-170, 2014.

HEALY, Paul M. The Effect of Bonus Schemes on Accounting Decisions. Journal of Accounting and Economics, v. 7, p. 85-107, 1985

HINDRIKS, J.; MYLES, G. D. Intermediate Public Economics. The MIT Press, 2006. 
HOGAN, B.; NOGA, T. The Association Between Changes in Auditor Provided Tax Services an Long-Term Corporate Tax Avoidance, 2012. Disponível em: <http://ssrn.com/abstract=1539637>. Acesso em: 21 dez. 2015.

HOOPES, J. L.; MESCALL, D.; PITTMAN, J. A. Do IRS Audits Deter Corporate Tax Avoidance? The Accounting Review, v. 87, n. 5, p 1603-1639, 2012.

HUTCHENS, M.; REGO, S. O. Does F=Greater Tax Risk lead to Increased Firm Risk? Disponível em: <http://ssrn.com/abstract=2186564>. Acesso em: 01 jan. 2015

HWANG, Y. J. Tax Enforcement and Restatements. Master Thesis. Departament of Accountancy of Tilburg School of Economics and Management. Tilburg University, 2012 Disponível em: < http://arno.uvt.nl/show.cgi?fid=130673>. Acesso em: 19 out. 2015.

JENKINS, N.; PINCUS, M. LIFO versus FIFO: updating what we have learned. Working paper, University of Iowa, 1998. Disponível em: <http://citeseerx.ist.psu.edu/ viewdoc/download?doi=10.1.1.194.7255\&rep=rep1\&type=pdf $>$. Acesso em: 10 mar. 2015.

JOHNSON, W. B.; DHALIWAL, D.S. LIFO Abandonment. Journal of Accounting Research, v. 26, n. 2, p. 236-272, 1988.

JONES, J. J. Earning Management During Import Relief Investigations. Journal of Accounting Research, v. 29, n. 2, 1991.

KAHNEMAN, D.; TVERSKY, A. Prospect Theory: An Analysis of Decision under Risk, Econometrica (pre-1986); v. 47, n. 2, p. 263-291, 1979.

KHAOULA, A.; ALI, Z. M. The board of directors and the corporate tax planning: Empirical Evidence from Tunisia. International Journal of Accounting and Financial Reporting, v. 2, n. 2, p.142-157, 2012

KOENKER, R.; BASSETT, G. Regression Quantiles. Econometrica, v. 46, n. 1, p. 33-50, 1978.

LANIS, R.; RICHARDSON, G. The effect of board of director composition on corporate tax aggressiveness. Journal of Accounting and Public Policy, v. 30, issue 1, p. 50-70, 2011. 
LAWRENCE, A.; MINUTTI-MEZA, M.; ZHANG, P. Can Big 4 versus Non-Big 4 Differences in Audit-Quality Proxies be Attributed to Client Characteristics? Accounting Review, v. 86, n. 1, p. 259-288, 2011.

LEE, K. Tax Evasion, Monopoly, and Nonneutral Profits Taxes. National Tax Journal, v. 51, n. 2, p. 333-338, 1998.

LENNOX, C. S.; LISOWSKY, P.; PITTMAN, J. Tax Agressiveness and Accounting Fraud. Journal of Accounting Research, v. 51, n. 4, p. 739-778, 2013.

LITAN, C. M.; VÂJU, S. C. Aggressive Corporate Tax Behavior versus Decreasing Probability of Fiscal Control. Working Paper, Universidad Carlos III de Madrid, Dept. of Economics, Madrid, 2008. Disponível em <http://www.eco.uc3m.es/ temp/S.Vaju_Jamboree_2008.pdf $>$. Acesso em: 09 set. 2015.

MCGUIRE, S. T.; OMER, T. C.; WANG, D. Tax Avoidance: Does Tax-Specific Industry Expertise Make a Difference?. The Accounting Review, v. 87, n. 3, p. 975-1003, 2012.

MADDALA, G. S. Introdução à Econometria. $3^{\text {a }}$ ed. Rio de Janeiro: LTC, 2003.

MAN, C.; WONG, B. Corporate Governance and Earnings Management: A Survey of Literature. The Journal of Applied Business Research, v. 29, n. 2, p. 391-418, 2013.

MANHIRE, J. Toward a Perspective-Dependent Theory of Audit Probability for Tax Compliance Models. Virginia Tax Review, v. 33, n. 4, p. 629-653, 2014.

MANZON; G.B., Jr.; PLESKO, G.A. The Relation Between Financial and Tax Reporting Measures of Income. Tax Law Review, v. 55, p. 175 - 214, 2002.

MARRELLI, M. On indirect tax evasion. Journal of Public Economics, v. 25, p.181-196, 1984.

.; MARTINA, R. Tax Evasion and Strategic Behaviour of the Firms. Journal of Public Economics, v. 37, p. 55-69, 1988.

MARTINEZ, A. L. Gerenciamento dos Resultados Contábeis: estudo empírico das companhias abertas brasileiras.. Tese (Doutorado em Ciências Contábeis) - Programa de Pós-Graduação em Ciências Contábeis , Departamento de Contabilidade e Atuária, Faculdade de Economia, Administração e Contabilidade da Universidade de São Paulo, 2001. 
The Role of Analysts as Gatekeepers: Enhancing Transparency and Curbing

Earnings Management in Brazil. RAC, v. 15, n. 4, art.8, p. 712-730, 2011.

.; RAMALHO, G. C. Family Firms and Tax Aggressiveness in Brazil. International

Business Research, v. 7, n. 3, p. 129-136, 2014

.; LESSA, R. C.; MORAES, A. J. Remuneração dos Auditores perante a Agressividade Tributária e Governança Corporativa no Brasil. Revista de Contabilidade e Controladoria, v. 6, n.3, p. 8-18, 2014.

.; FILHO, R. F.; ANUNCIAÇÃO, E. P. Analysis of the Relationship between the Components of Book-Tax Differences and Annual Variations in Earnings and Tax Expenses of Firms Listed on the BMF\&Bovespa. Advances in Scientific and Applied Accounting, v.6, n.3, p. 396-417, 2013.

MELLO, H. R.; SALOTTI, B. M. Efeitos do regime tributário de transição na carga tributária das companhias brasileiras. Revista de Contabilidade e Organizações, v. 7, n. 19, p. 3-15, 2013.

MILLS, Lilian F. Corporate Tax Compliance and Financial Reporting. National Tax Journal, v. 49, n. 3, p. 421-435, 1996.

Book-Tax Differences and Internal Revenue Services Adjustments. Journal of Accounting Research, v. 36, n. 2, p. 343-356, 1998.

; SANSING, R. C. Strategic Tax and Financial Reporting Decisions: theory and evidence. Contemporary Accounting Research, v. 17, n. 1, p. 85-106, 2000.

NOH, M.; MOON, D.; GUIRAL, A. The Effect of Auditor-Provided Tax Services on Tax and Financial Reporting Aggressiveness. Advanced Science and Technology Letters, v.47, p.89-92, 2014.

PAULO, E. Manipulação das Informações Contábeis: uma análise teórica e empírica sobre os modelos operacionais de detecção de gerenciamento de resultados. Tese (Doutorado em Ciências Contábeis) - Programa de Pós-Graduação em Ciências Contábeis , Departamento de Contabilidade e Atuária, Faculdade de Economia, Administração e Contabilidade da Universidade de São Paulo, 2007.

; MARTINS, E.; CORRAR, L. J. Detecção do Gerenciamento de Resultados pelas Análise do Diferimento Tributário. Revista de Administração de Empresas. v. 47, n. 1, p. 47-57, 2007. 
PEASNELL, K. V.; POPE, P. F.; YOUNG, S. Detecting Earnings Management Using CrossSectional Abnormal Accruals Models. Accounting and Business Research, v. 30, n.4, p. 313-326, 2000.

PIQUEIRAS, T. M. Relação das Diferenças entre o Lucro Contábil e o Lucro Tributável (Book-tax Differences) e Gerenciamento de Resultados no Brasil. Tese (Doutorado em Ciências Contábeis) - Programa de Pós-Graduação em Ciências Contábeis , Departamento de Contabilidade e Atuária, Faculdade de Economia, Administração e Contabilidade da Universidade de São Paulo, 2010.

PHILLIPS, J. D. Corporate Tax-Planning Effectiveness: The Role of Compensation-Based Incentives. The Accounting Review, v. 78, n. 3, p. 847-874, 2003.

.; PINCUS, M.; REGO S. O. Earnings Management: New evidence based on deferred tax expense. The Accounting Review, v. 78, n. 2, p. 491-521, 2003.

PLESKO, G. A. Corporate Tax Avoidance and the Properties of Corporate Earnings. National Tax Journal, vol. LVII, n. 3, p. 729-737, 2004.

POHLMANN, M. C.; IUDÍCIBUS, S. Relação entre Tributação do Lucro e a Estrutura de Capital das Grandes Empresas no Brasil. Revista Contabilidade \& Finanças - USP, v. 21, n. 53, p. 1-25, 2010.

POLINSKY, A. M.; SHAVELL, S. The Optimal Tradeoff between the Probability and Magnitude of Fines. The American Economic Review, v. 69, n. 5, p. 880-891, 1979.

RABLEN, M. D. Audit Probability Versus Effectiveness: The Beckerian Approach Revisited. Journal of Public Economic Theory, v. 16, issue 2, p. 322-342, 2014.

REGO, S. O.; WILSON, R. J. Equity Risk Incentives and Corporate Tax Aggressiveness. Journal of Accounting Research, v. 50, issue 3, p. 775-810, 2012.

REINGANUM, J. F.; WILDE, L. L. Income tax Compliance in a Principal-Agent Framework. Journal of Public Economics, v. 26, p. 1-18, 1985.

.; ___ Equilibrium Verification and Reporting Policies in a Model of Tax

Compliance. International Economic Review, v. 27, n. 3, p. 739-760, 1986. 
REITSEMA, G. J. Effects of IRS Monitoring on Earnings Management via Unrecognized Tax Benefits. Master Thesis. Departament of Accountancy of Tilburg School of Economics and Management. Tilburg University. 2012. Disponível em <http://arno.uvt.nl/show.cgi? fid=127164>. Acesso em: 19 out. 2015.

REZENDE, G. P.; NAKAO, S. H. Gerenciamento de Resultados e a Relação com o Lucro Tributável das Empresas Brasileiras de Capital Aberto. Revista Universo Contábil, Blumenau, v. 8, n. 1, p. $6-21,2012$.

RICHARDSON, G.; TAYLOR, G.; LANIS, R. The impact of board of director oversight characteristics on corporate tax aggressiveness: An empirical analysis. Journal of Accounting and Public Policy, v. 32, p. 68-88, 2013.

SALAMON, L. M.; SIEGFRIED, J. J. Economic Power and Political Influence: The Impact of Industry Structure on Public Policy, The American Political Science Review, v. 71, n. 3, p. 1026-1043, 1977.

SANDMO, A. The Theory of Tax Evasion: A Retrospective View. National Tax Journal, v. 58, p. 643-663, 2005.

SANTOS, M. A. C. Contabilidade Tributária: Um enfoque nos IFRS e na legislação do IRPJ. São Paulo: Atlas, 2015.

.; CAVALCANTE, P. R. N.; RODRIGUES, R. N. Tamanho da Firma e Outros Determinantes da Tributação Efetiva sobre o Lucro no Brasil. Advances in Scientific and Applied Accounting, v.6, n.2, p. 179-210, 2013.

SCHOLES, M. S.; WILSON, G. P.; WOLFSON, M. A. Firm's Responses to Antecipated Reductions in Tax Rates: The Tax Reform Act of 1986. Journal of Accounting Research, v. 30, Studies on Accounting and Taxation, p. 161-185, 1992.

et al. Taxes and Business Strategy: A Planning Approach. $4^{\mathrm{a}}$ ed. New Jersey: Pearson Prentice Hall, 2009.

SCOTCHMER, S.; SLEMROD, J. Randomness in Tax Enforcement. Journal of Public Economics, v. 38, p. 17-32, 1989

SEIDMAN, J. K.; STOMBERG, B. Equity Compensation and Tax Sheltering: Are They Negatively Related due Incentives or Tax Benefits?, 2012. Disponível em: <http://ssrn.com/ abstract=1904936>. Acesso em: 05 out. 2015. 
SERAFAT, S.; BARZEGAR, G. Investigating the relation between tax avoidance and auditor tenure in the listed companies in Tehran stock exchange. Journal of Scientific Research and Development, v. 2, n. 4, p. 1-5, 2015.

SHACKELFORD, D. A; SHEVLIN, T. Empirical Tax Research in Accounting. Journal of Accounting and Economics, v. 31, p. 321 - 387, 2001.

SILVA, A. F. et al. SPED - Public Digital Bookkeeping System: influence in the economicfinancial results declared by companies. Review of Business Management, v.15, n.48, p. 445-461, 2013

SIQUEIRA, M. L. Um Modelo Econômico para Análise da Evasão Fiscal do Imposto de Renda no Brasil. Tese (Doutorado em Economia). Programa de Pós-Gradução em Economia, Universidade Federal de Pernambuco, 2004.

.; RAMOS, F. S. A Economia da Sonegação: Teorias e Evidências Empíricas. Revista Economia Contemporânea, v. 9, n. 3, p. 555-581, 2005.

SLEMROD, J. Cheating Ourselves: The Economics of Tax Evasion. Journal of Economics Perspectives, v. 21, n. 1, p. 25-48, 2007.

.; YITZHAKI, S. Tax avoidance, evasion and administration. In: AUERBACH, A. J.; Feldstein, M. (eds.). Handbook of Public Economics, v. 3. Amsterdam: Elsevier Science, p. 1423-1470, 2002.

SOUR, Laura. An Economic Model of Tax Compliance with Individual Morality and Group Conformity. economía Mexicana NUEVA ÉPOCA, v.8, n.1, p.43-61, 2004.

SRINIVASAN, T. N. Tax Evasion: A Model. Journal of Public Economics, v. 2, p. 339346, 1973.

STAIGER, D.; STOCK, J. H. Instrumental Variables Regression with Weak Instruments. Econometrica, v. 65, p. 557-586, 1997.

STICKNEY; Clyde P.; MCGEE; Victor E. Effective Corporate Tax Rates: The effect of Size, Capital Intensity, Leverage and Other Factors. Journal of Accounting and Public Policy, v. 1, p. 125-152, 1982. 
STOCK, J. H.; YOGO, M. Testing for Weak Instruments in Linear IV Regression. In: STOCK, J. H.; ANDREWS, D. W. K. (eds). Identification and Inference for Econometric Models: Essays in Honor of Thomas J. Rothenberg. Cambridge University Press, 2005.

TANG, T. Y. H. Book-Tax Differences, a Proxy for Earnings Management and Tax Management - empirical evidence from China. (última revisão: 10/04/2011), 2011. Disponível em: <http://ssrn.com/abstract=872389>. Acesso em: 05 ago. 2015

; FIRTH, M. Can Book-Tax Differences Capture Earnings Management and Tax management? empirical evidence from China. The International Journal of Accounting, v. 46, n. 2 , p. $175-204,2011$.

TVERSKY, A.; KAHNEMAN , D. Advances in Prospect Theory: Cumulative Representation of Uncertainty. Journal of Risk and Uncertainty, v. 5, p. 297-323, 1992.

VARIAN, H. R. Microeconomia: uma abordagem moderna. 8 ed. Rio de Janeiro: Elsevier, 2012

VASCONCELOS, C.; MIYASHIRO, I.; REIS, D.; PAULO, E. A Influência da Cobertura das Empresas de Rating sobre o Gerenciamento de Resultados das Companhias Abertas Brasileiras. Revista de Contabilidade e Organizações, v. 3, n. 2, p. 37-52, 2008.

VIRMANI, A. Indirect Tax Evasion and Production Efficiency. Journal of Public Economics, v. 39, p. 223-237, 1989.

WANG, L. F. S.; CONANT, J. L. Corporate Tax Evasion and Output Decisions of the Uncertain Monopolist. National Tax Journal, v.41, p. 579-581, 1988

Tax Evasion and Monopoly Output Decisions. Public Finance Review, v. 18, n. 4, p. $480-487,1990$.

WATTS, R. L.; ZIMMERMAN, J. L. Positive Accounting Theory. New Jersey: Prentice Hall, 1986.

WEISBACH, D. A. Corporate Tax Avoidance. U. Chicago Law \& Economics. John M. Olin Program in Law \& Economics Working Paper n. 202, 2004. Disponível em: <http://ssrn.com/abstract=487103>. Acesso em: 30 out. 2015.

WILSON, R. J. An Examination of Corporate Tax Shelter Participants. The Accounting Review, v. 84, n. 3, p. 969-999, 2009. 
WOOLDRIDGE, Jeffrey M. Econometric Analysis of Cross Section and Panel Data.

London: MIT Press, 2002.

WU, G.; GONZALEZ, R. Curvature of the Probability Weighting Function. Management Science, v. 42, n. 12, p. 1676-1690, 1996.

XU, W.; ZENG, Y.; ZHANG, J. Tax Enforcement as a Corporate Governance Mechanism: empirical evidence from China. Corporate Governance: An International Review, v. 19, n. 1, p. 25-40, 2011.

YANIV, G. A Note on the Tax-Evading Firm. National Tax journal, v. 48, n. 1, pp 113-120, 1995.

Tax Evasion and Monopoly Output Decisions: Note. Public Finance Review, v. 24, n. 4, p. 501-505, 1996.

The Tax Compliance Demand Curve: A Diagrammatical Approach to Income Tax Evasion. Journal of Economic Literature, v. 40, n. 2, p. 213-224, 2009.

YASAR, A. Big Four Auditors' Audit Quality and Earnings Management: Evidence from Turkish Stock Market. International Journal of Business and Social Science, v. 4, n. 17 (special issue), p. 153-163, 2013.

YITZHAKI, S. Income Tax Evasion: A Theoretical Analysis. Journal of Public Economics, v. 3, p. $201-202,1974$.

YOON, S. S.; YOO, S. W.; KIM, J. Ambiguity, Audit Errors, and Tax Compliance. AsiaPacific Journal of Accounting \& Economics, v.18, p. 11-26, 2011.

YU, F. Analysts' coverage and earnings management. Journal of Financial Economic, v. 88, n. 2, p. 245-271, 2008.

ZARO, C. S. Efeito Tributário na Configuração do Sistema de Remuneração Gerencial. Tese (Doutorado em Ciências Contábeis) - Programa de Pós-Graduação em Ciências Contábeis, Departamento de Contabilidade e Atuária, Faculdade de Economia, Administração e Contabilidade da Universidade de São Paulo, 2015.

ZEMZEM, A.; FTOUHI, K. The Effects of Board of Directors' Characteristics on Tax Aggressiveness. Research Journal of Finance and Accounting,v.4, n. 4, p. 140-157, 2013

ZIMMERMAN, J. L. Taxes and Firm Size. Journal of Accounting and Economics, v. 5, p. 119-149, 1983. 


\section{APÊNDICE A: SEMÂNTICA DA EVASÃO TRIBUTÁRIA}

A literatura internacional, no âmbito da contabilidade e da economia, tem empregado diversas expressões para denominar fenômenos, comportamentos, estratégias ou mecanismos relacionados à redução da tributação. Tax evasion, tax avoidance, tax sheltering, tax agressiveness, tax fraud, tax concealment, tax mitigation, aggressive tax planning/behavior, effective tax planning, são exemplos da terminologia comumente utilizada.

No Brasil, não é diferente. As expressões mais encontradas são evasão tributária/fiscal, sonegação fiscal, fraude tributária, elisão tributária/fiscal, elusão tributária/fiscal e planejamento tributário abusivo. Além disso, já é possível encontrar o uso de expressões na língua inglesa, como é o caso da tax avoidance que é empregada por Martinez, Lessa e Moraes (2014).

Diante dessa multiplicidade de expressões, um problema que é observado é a imprecisão semântica, uma vez que o significado e o alcance dessas expressões, muitas vezes, variam de acordo com o contexto em que estão inseridas (SLEMROD, 2007; HANLON; HEITZMAN, 2010). De acordo com Weisbach (2004), a maioria dos estudos que tratam da tax avoidance e da tax evasion utiliza esses termos como se soubessem o seu significado. Para ele, o verdadeiro problema seria a deficiência na análise dos vários incentivos que motivam as estratégias tributárias, o que impossibilitaria uma definição mais acurada.

Por exemplo, a "tax evasion” em Allingham e Sandmo (1972) é estritamente relacionada à redução da tributação por meio da omissão intencional de renda, praticada pelo indivíduo, cuja detecção implicaria em penalidade. Definição que também foi adotada por Crocker e Slemrod (2005), que estendem o escopo da penalidade para as esferas jurídicas civil e penal. Slemrod (2007) também utilizou o termo "evasion", no entanto de forma mais abrangente, sem qualquer restrição quanto à imposição de penalidades.

Dyreng, Hanlon e Maydew (2008), por sua vez, utilizaram a expressão "tax avoidance" para se referir a qualquer estratégia que reduz a alíquota tributária efetiva sobre o caixa da firma durante um longo período de tempo (no caso, dez anos). Essa escolha foi justificada pelo fato de que o objetivo do estudo foi avaliar a redução da tributação, independentemente da legalidade da estratégia implementada.

Já Hanlon e Heitzam (2010) definiram, de uma forma bastante abrangente, "tax avoidance" como sendo a redução da tributação explícita, o que contempla todos os 
comportamentos tributários, legais ou não, que propiciam esse resultado. Segundo eles, essa definição busca reduzir o foco nos problemas semânticos que gravitam em torno do tema.

Muito embora não elimine a imprecisão semântica de toda essa terminologia, um aspecto-chave para a distinção e a classificação das estratégias tributárias refere-se à legalidade. De uma maneira geral, a literatura nacional e internacional é consensual ao definir a evasão tributária como a redução da tributação realizada por meio de estratégias consideradas ilegais. Em outro extremo, tem-se a elisão tributária (tax avoidance ou tax planning), a qual operacionaliza aquela redução por meio de estratégias consideradas legais (FRAZONI, 1999; SIQUEIRA; RAMOS, 2005; SANDMO, 2005; SLEMROD, 2007; HANLON; HEITZMAN, 2010; ANCIŪTE்; KROPIENE், 2010).

O fato é que essa distinção resolve uma parte do problema: a definição. A evasão é ilegal e a elisão é legal. No entanto, surge uma outra questão que se relaciona ao alcance dessa definição: o que pode ser considerado legal ou ilegal? E essa é a maior fonte de imprecisão, uma vez que a linha que separa aquilo que é considerado legal ou ilegal não é suficientemente clara. Segundo Weisbach (2004), a ambiguidade sobre a legalidade das estratégias tributárias $\left(\right.$ tax shelters $\left.{ }^{66}\right)$ seria uma constante, mesmo em relação àquelas consideradas típicas. Além disso, Garbarino (2008) pontua que, como tal distinção é uma questão eminentemente jurídica, tem-se que, em cada país, a tax avoidance e a tax evasion podem possuir alcances diferentes.

Como exemplo daquela ambiguidade, tem-se as estratégias que, formalmente, podem ser consideradas legais e, portanto, elisivas, mas que, no entanto, abusam da forma jurídica das transações (dissimulação), pois não possuem qualquer propósito negocial ou substância econômica, uma vez que o seu único objetivo é a redução da tributação. Tais estratégias podem ser classificadas como elusão fiscal ou como modalidades agressivas de tax shelters.

No Brasil, é possível citar, nesse sentido, as operações denominadas de “ágio interno", sob as quais as firmas alienam participações societárias de firmas do mesmo grupo econômico para outra que também integra esse grupo, de modo a gerar ágios artificiais que poderão ser aproveitados tributariamente após a realização de uma reorganização societária ${ }^{67}$.

\footnotetext{
${ }^{66}$ Tax shelters são métodos legais utilizados para redução da tributação. Podem ser considerados uma modalidade de tax avoidance (ou estratégias de planejamento tributário). Geralmente, são implementados por meio de investimentos que possuem tratamento tributário favorável, seja pela isenção dos rendimentos, ou pela aceleração de despesas, ou criação de despesas ou perdas dedutíveis. A dedutibilidade dos juros sobre o capital próprio e da participação nos lucros dos detentores de debêntures da firma podem ser considerados exemplos de tax shelters.

${ }^{67}$ Segue um exemplo: A firma X controla as firmas Y e Z. A firma X subscreve capital em Y com ações de Z, por um valor superior ao patrimonial, gerando assim um ágio (goodwill). Na sequência, Y incorpora $\mathrm{Z}$ e aproveita o ágio reconhecido
} 
A $R F B$ tem considerado essas operações como planejamento tributário abusivo e tem autuado alegando que as alienações e as reorganizações societárias não possuem substância econômica, tampouco propósito negocial, e visam, exclusivamente, a redução da tributação (RFB, 2014, 2015a). Entretanto, esse entendimento não é pacífico no âmbito Conselho Administrativo de Recursos Fiscais (CARF) que, em casos específicos, já reconheceu a legalidade de tais operações. Um exemplo disso são os acórdãos nº 1101-000.708/2012, 1101000.709/2012 e 1101-000.710/2012, relativos às operações realizadas pelas firmas Gerdau Açominas S.A., Gerdau Comercial de Aços S.A. e Gerdau Aços Especiais S.A.

A despeito de toda a controvérsia jurídica inerente ao assunto, tem-se que, via de regra, se a estratégia é ilegal, então, se detectada, estará sujeita a uma penalidade. E esse é o aspecto de maior interesse para o presente trabalho.

As infrações à legislação do IRPJ e da CSLL sujeitam-se às multas previstas no art. 44 da Lei no 9.430/1996. A penalidade "padrão" é de 75\% sobre o montante do imposto não pago ou não declarado (inciso I do art. 44). Por exemplo, o tributo apurado a menor, em função da ausência do ajuste (adição) de uma despesa indedutível, estará sujeito a tal penalidade.

Contudo, se a redução da tributação se der por meio de sonegação, fraude ou conluio ${ }^{68}$, a penalidade passa a ser de $150 \%\left(\S 1^{\circ}\right.$ do art. 44). Penalidade esta que seria aplicável, por exemplo, no caso da utilização de uma despesa fícta, lastreada em documento falso, na apuração do IRPJ, ou no caso de uma operação em que seja verificado o abuso de forma, tais como, as operações de ágio interno, muito embora, neste último caso, tal aplicação seja controversa.

\footnotetext{
${ }^{68}$ Para a qualificação da penalidade prevista no $\S 1^{\circ}$ do art. 44 da Lei $n^{\circ} 9.430 / 1996$, a definição da sonegação, da fraude e do conluio, são as contidas nos arts. 71, 72 e 73 da Lei ${ }^{\circ} 4.502 / 1964$, abaixo transcritos:

“Art . 71. Sonegação é tôda ação ou omissão dolosa tendente a impedir ou retardar, total ou parcialmente, o conhecimento por parte da autoridade fazendária:

I - da ocorrência do fato gerador da obrigação tributária principal, sua natureza ou circunstâncias materiais;

II - das condições pessoais de contribuinte, suscetíveis de afetar a obrigação tributária principal ou o crédito tributário correspondente.

Art . 72. Fraude é tôda ação ou omissão dolosa tendente a impedir ou retardar, total ou parcialmente, a ocorrência do fato gerador da obrigação tributária principal, ou a excluir ou modificar as suas características essenciais, de modo a reduzir o montante do impôsto devido a evitar ou diferir o seu pagamento.
}

Art . 73. Conluio é o ajuste doloso entre duas ou mais pessoas naturais ou jurídicas, visando qualquer dos efeitos referidos nos arts. 71 e $72 . "$ 
Um complicador adicional é que há estratégias que podem ser interpretadas como crime contra ordem tributária, nos termos da Lei nº 8.137/1990, mas que, necessariamente, não se enquadram na situação legal prevista para a aplicação da penalidade de $150 \%$. Por exemplo, a omissão de informação que implica na redução ou supressão de tributo constitui-se crime, conforme o inciso I do art. $1^{\circ}$ da Lei $n^{\circ} 8.137 / 1990$, no entanto, pode ser que essa conduta não seja tipificada como sonegação, fraude ou conluio, assim, em princípio, ela sujeitar-se-ia à penalidade de $75 \%$.

A distinção entre as infrações sujeitas a tais penalidades requer a tipificação jurídica da conduta do contribuinte, o que se dá por meio da avaliação da "gravidade" ou "agressividade" da estratégia tributária implementada, à luz das definições legais. No entanto, mesmo sob o risco de falhar no rigor semântico-jurídico, seria possível conceber que haveria estratégias: (i) legais; (ii) ilegais, exclusivamente na esfera tributária; e (iii) ilegais agressivas (abusivas, fraudulentas, dissimulatórias etc.), que violam o ordenamento jurídico nas searas tributária e penal. Em que as duas últimas seriam aquelas sujeitas às penalidades de $75 \%$ e $150 \%$, respectivamente.

Weisbach (2004) argumenta que, sob a perspectiva do bem-estar social, não seria possível pré-conceber definições para a tax avoidance e a tax evasion, mas sim, realizar a distinção com base nas consequências sociais do comportamento observado, pois, sem essa referência, quaisquer condutas deveriam ser tratadas da mesma maneira. Desse modo, ele defende que a evasão tributária deveria compreender apenas aquelas atividades cuja penalização socialmente ótima fosse a criminal. Sob tal acepção, poderíamos considerar, em princípio, como evasão tributária apenas aquelas infrações sujeitas à penalidade de $150 \%$, muito embora aquelas sujeitas aos $75 \%$ também sejam ilegais.

No entanto, Weisbach (2004) reconhece que a segregação entre evasion e avoidance não é algo "sagrado", de modo que, alternativamente, os comportamentos poderiam ser divididos em tantas categorias quanto fossem necessárias, com penalidades escalonadas entre elas.

A categorização aqui proposta alinha-se à Anciūtė e Kropienè (2010), que classificam as estratégias tributárias em 3 categorias, assim tem-se:

a) Estratégias legais - aquelas realizadas dentro da lógica do negócio no qual são implementadas as atividades econômicas reais, que permitem a redução da tributação. As informações sobre tais atividades são fornecidas corretamente à 
autoridade tributária. Tais ações estão no escopo do que é possível denominar de planejamento tributário. No Brasil, essa prática pode ser classificada como elisão tributária (na língua inglesa é atribuível às expressões tax mitigation, tax planning, tax optimisation e tax avoidance).

b) Estratégias ilegais - as que visam omitir, total ou parcialmente, informações sobre as atividades econômicas reais, as quais podem ser caracterizadas como evasão tributária ( $\mathrm{Na}$ língua inglesa tem-se tax evasion, tax concealment e, de acordo com alguns autores, também tax avoidance)

c) Estratégias ilegais fraudulentas - aquelas que dissimulam atividades reais, realizadas por meio de fraudes tributárias, as quais também se enquadram no escopo da evasão tributária (na língua inglesa é utilizada a expressão tax fraud)

Dessa maneira, não importaria apenas se a estratégia é legal ou ilegal, mas também o quão ilegal ela seria, ou seja, se a infração seria apenas tributária ou se também representaria um crime. No entanto, essa classificação exigiria a análise de cada situação, a fim de avalia-las nesse sentido.

Portanto, dada a impossibilidade de realizar tal tarefa no âmbito dessa pesquisa e ante a necessidade de reduzir a imprecisão semântica ao longo de todo trabalho, a evasão tributária é aqui entendida como a redução da tributação por meio de qualquer estratégia que represente uma infração à legislação tributária, de modo que, se detectada pela autoridade tributária, acarretará a imposição de uma penalidade pecuniária, independentemente da sua repercussão na esfera penal. 


\section{APÊNDICE B: RESULTADOS DAS ESTIMAÇÕES DO MODELO (32)}

$$
\begin{aligned}
\text { ESC }_{i t}= & \beta_{0}+\beta_{1} \text { Prob }_{i t}+\beta_{2} \text { Prob_Dif }_{i t}+\beta_{3} \text { DCTA }_{i t} \\
& +\lambda_{1} \text { Inv }_{\text {Inst }}+\lambda_{i t}+\lambda_{2} \text { Gov }_{i t}+\lambda_{3} \text { Rem }_{i t}+\lambda_{4} \text { Analist }_{i t}+\lambda_{5} \text { Endv }_{i t} \\
& +\delta_{1} \text { Ativo }_{i t}+\delta_{2} d 2011+\delta_{3} d 2012+\delta_{4} d 2013+\varepsilon_{i t}
\end{aligned}
$$

\begin{tabular}{|c|c|c|c|c|c|c|c|}
\hline \multirow{3}{*}{ Obs $=846$} & \multirow{3}{*}{$\begin{array}{l}\text { Sinal } \\
\text { Previsto }\end{array}$} & \multicolumn{6}{|c|}{$\begin{array}{l}\text { Coeficientes } \\
\text { (estatísticas } t \text { ) }\end{array}$} \\
\hline & & \multirow[t]{2}{*}{ MQO } & \multicolumn{5}{|c|}{$\begin{array}{l}\text { Regressão Quantílica } \\
\text { (Erros padrão robustos) }\end{array}$} \\
\hline & & & Q05 & Q25 & Q50 & Q75 & Q95 \\
\hline Const & $?$ & $\begin{array}{c}0,220 \\
(1,580)\end{array}$ & $\begin{array}{l}-0,494^{* * *} \\
(-4,528)\end{array}$ & $\begin{array}{c}-0,037 \\
(-0,539)\end{array}$ & $\begin{array}{l}0,174^{* * *} \\
(3,090)\end{array}$ & $\begin{array}{l}0,497^{* * *} \\
(5,138)\end{array}$ & $\begin{array}{l}1,741^{* * *} \\
(8,265)\end{array}$ \\
\hline Prob & - & $\begin{array}{l}7,611^{* * * *} \\
(6,197)\end{array}$ & $\begin{array}{c}-0,026 \\
(-0,045) \\
\end{array}$ & $\begin{array}{l}2,053^{* * *} \\
(5,701)\end{array}$ & $\begin{array}{l}3,102^{* * *} \\
(10,459)\end{array}$ & $\begin{array}{l}4,416^{* * * *} \\
(8,679) \\
\end{array}$ & $\begin{array}{l}3,386^{* * * *} \\
(3,058)\end{array}$ \\
\hline Prob_Dif & - & $\begin{array}{c}-0,187 \\
(-1,459)\end{array}$ & $\begin{array}{l}0,216^{* * * *} \\
(3,196)\end{array}$ & $\begin{array}{c}-0,061 \\
(-1,436)\end{array}$ & $\begin{array}{l}-0,166^{* * * *} \\
(-4,748)\end{array}$ & $\begin{array}{l}-0,216^{* * *} \\
(-3,606)\end{array}$ & $\begin{array}{l}-0,500^{* * *} \\
(-3,840)\end{array}$ \\
\hline$D C T A$ & + & $\begin{array}{l}0,525^{* * * *} \\
(3,275)\end{array}$ & $\begin{array}{l}0,610^{* * * *} \\
(4,524)\end{array}$ & $\begin{array}{l}0,383^{* * * *} \\
(4,531)\end{array}$ & $\begin{array}{l}0,469^{* * *} \\
(6,735)\end{array}$ & $\begin{array}{l}0,861^{* * * *} \\
(7,202)\end{array}$ & $\begin{array}{l}0,836^{* * * *} \\
(3,211)\end{array}$ \\
\hline Inv_Inst & - & $\begin{array}{c}-0,019 \\
(-0,163)\end{array}$ & $\begin{array}{c}-0,018 \\
(-0,284)\end{array}$ & $\begin{array}{c}0,062 \\
(1,593)\end{array}$ & $\begin{array}{l}0,138^{* * *} \\
(4,315)\end{array}$ & $\begin{array}{c}0,088 \\
(1,600)\end{array}$ & $\begin{array}{l}-0,075 \\
(-0,629)\end{array}$ \\
\hline Gov & - & $\begin{array}{c}-0,005 \\
(-0,210) \\
\end{array}$ & $\begin{array}{c}0,035 \\
(1,571)\end{array}$ & $\begin{array}{c}-0,011 \\
(-0,785) \\
\end{array}$ & $\begin{array}{l}-0,039^{* * * *} \\
(-3,420)\end{array}$ & $\begin{array}{l}-0,020 \\
(-1,035) \\
\end{array}$ & $\begin{array}{c}-0,035 \\
(-0,833) \\
\end{array}$ \\
\hline Rem & + & $\begin{array}{c}0,026 \\
(0,960)\end{array}$ & $\begin{array}{c}0,026 \\
(1,270)\end{array}$ & $\begin{array}{l}0,048^{* * *} \\
(3,764)\end{array}$ & $\begin{array}{l}0,051^{* * *} \\
(4,802)\end{array}$ & $\begin{array}{l}0,035^{* * *} \\
(1,951)\end{array}$ & $\begin{array}{l}-0,136^{* * *} \\
(-3,448)\end{array}$ \\
\hline Analist & - & $\begin{array}{c}0,001 \\
(0,627)\end{array}$ & $\begin{array}{c}-0,001 \\
(-0,349)\end{array}$ & $\begin{array}{l}-0,0002 \\
(-0,135)\end{array}$ & $\begin{array}{l}0,002^{*} \\
(1,819)\end{array}$ & $\begin{array}{l}0,003^{*} \\
(1,832)\end{array}$ & $\begin{array}{c}0,005 \\
(1,458)\end{array}$ \\
\hline$E n d v$ & ? & $\begin{array}{l}-0,054^{\text {*** }} \\
(-2,925)\end{array}$ & $\begin{array}{l}-0,083^{* * *} \\
(-44,106)\end{array}$ & $\begin{array}{l}-0,085^{* * *} \\
(-71,523)\end{array}$ & $\begin{array}{l}-0,080^{* * *} \\
(-81,744)\end{array}$ & $\begin{array}{l}-0,014^{* * *} \\
(-8,158)\end{array}$ & $\begin{array}{l}-0,006^{*} \\
(-1,781)\end{array}$ \\
\hline Ativo & + & $\begin{array}{l}-0,015^{* *} \\
(-2,097)\end{array}$ & $\begin{array}{l}0,015^{* * *} \\
(2,728)\end{array}$ & $\begin{array}{c}-0,002 \\
(-0,729)\end{array}$ & $\begin{array}{l}-0,010^{* * *} \\
(-3,515)\end{array}$ & $\begin{array}{l}-0,019^{* * * *} \\
(-3,944)\end{array}$ & $\begin{array}{l}-0,018^{*} \\
(-1,688)\end{array}$ \\
\hline \multicolumn{2}{|c|}{ Dummies temporais } & Sim & \multicolumn{5}{|c|}{ Sim } \\
\hline \multicolumn{2}{|l|}{ PseudoR ${ }^{2}$} & & 0,4648 & 0,1989 & 0,1207 & 0,1092 & 0,2703 \\
\hline \multicolumn{2}{|l|}{$\begin{array}{l}R^{2} \\
\left(R^{2} \text { ajust. }\right)\end{array}$} & $\begin{array}{c}0,3320 \\
(0,3224)\end{array}$ & & & & & \\
\hline \multicolumn{2}{|l|}{ Teste $F$} & $9,381^{* * * *}$ & & & & & \\
\hline \multicolumn{2}{|c|}{ Heterocedasticidade } & $3355,853^{* * *}$ & \multicolumn{2}{|c|}{ (Breusch-Pagan) } & & & \\
\hline \multicolumn{2}{|c|}{ Normalidade } & $561,877^{* * * *}$ & \multicolumn{2}{|c|}{ (Doornik-Hansen) } & & & \\
\hline \multicolumn{2}{|c|}{ Multicolinearidade } & VIFs $<2,5$ & & & & & \\
\hline
\end{tabular}

Tabela 20 - Resultados para a Amostra Total - Equação (32)

*,** e *** indicam a significância estatística bicaudal a $10 \%, 5 \%$; e $1 \%$, respectivamente.

Fonte: dados da pesquisa 
Tabela 21 - Resultados para a Decisão 1 - Equação (32)

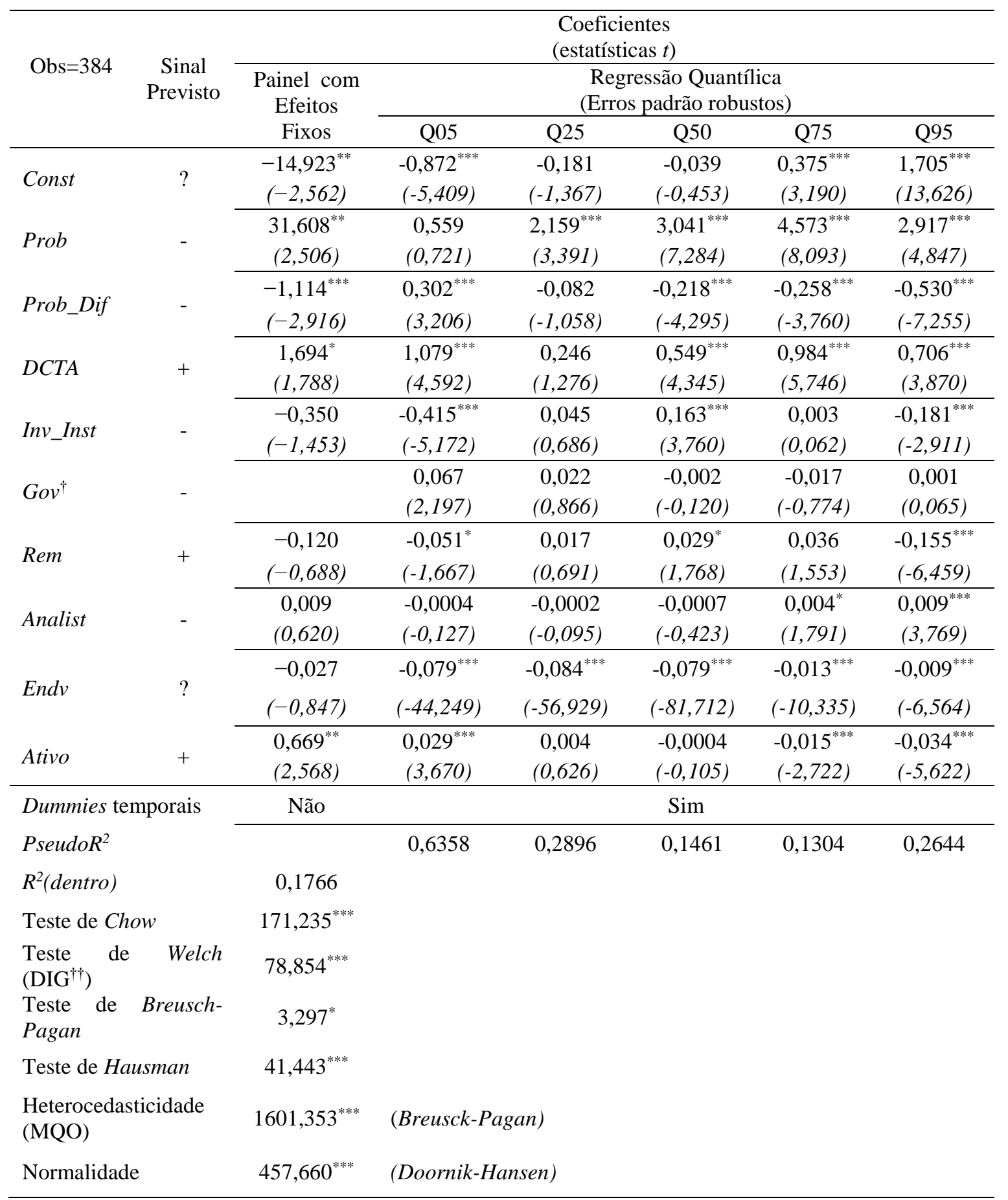

${ }^{\dagger}$ A variável Gov foi omitida na estimação do painel com efeitos fixos em razão de colinearidade exata.

$\dagger$ DIG - Diferenciação de Interceptos de Grupos

$*, * * \mathrm{e}^{* * *}$ indicam a significância estatística bicaudal a $10 \%, 5 \%$; e $1 \%$, respectivamente.

Fonte: dados da pesquisa 
Tabela 22 - Resultados para a Decisão 2 - Equação (32)

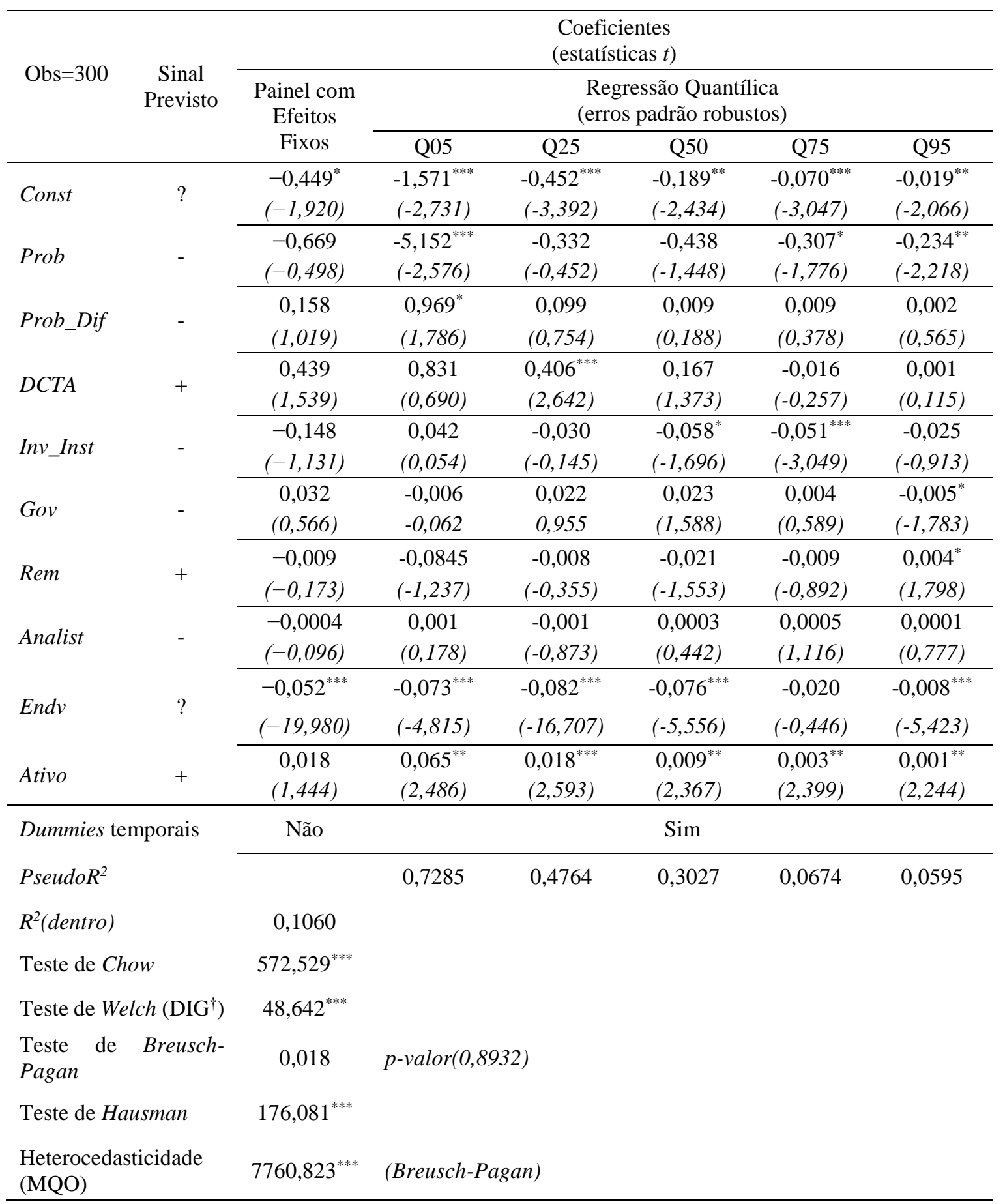

${ }^{\dagger}$ DIG - Diferenciação de Interceptos de Grupos

$*, * * \mathrm{e} * * *$ indicam a significância estatística bicaudal a $10 \%, 5 \%$; e 1\%, respectivamente.

Fonte: dados da pesquisa 
Tabela 23 - Resultados para a Decisão 3 - Equação (32)

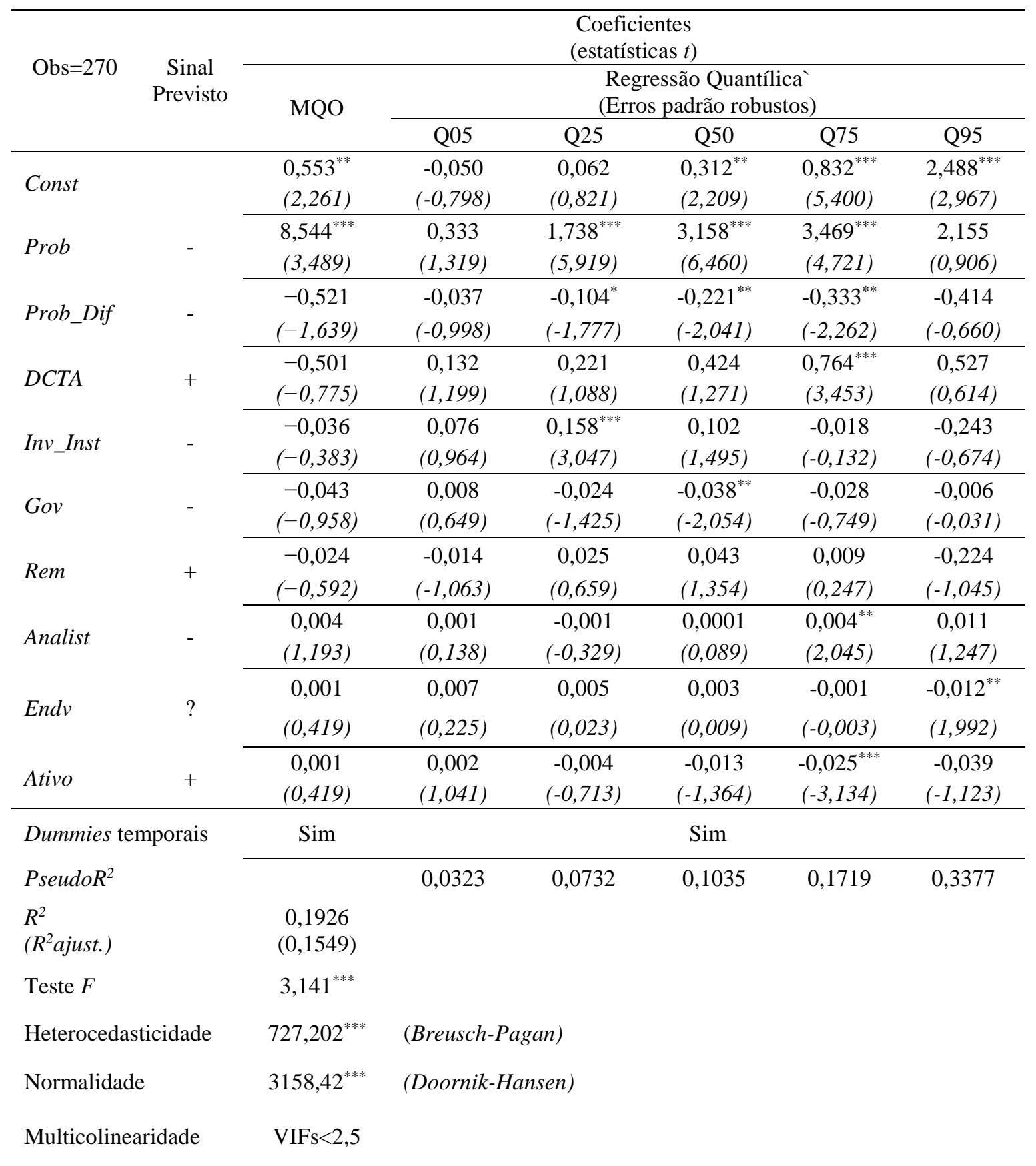

$*, * * \mathrm{e} * * *$ indicam a significância estatística bicaudal a $10 \%, 5 \%$; e 1\%, respectivamente.

Fonte: dados da pesquisa 
Tabela 24 - Resultados para a Decisão 4 - Equação (32)

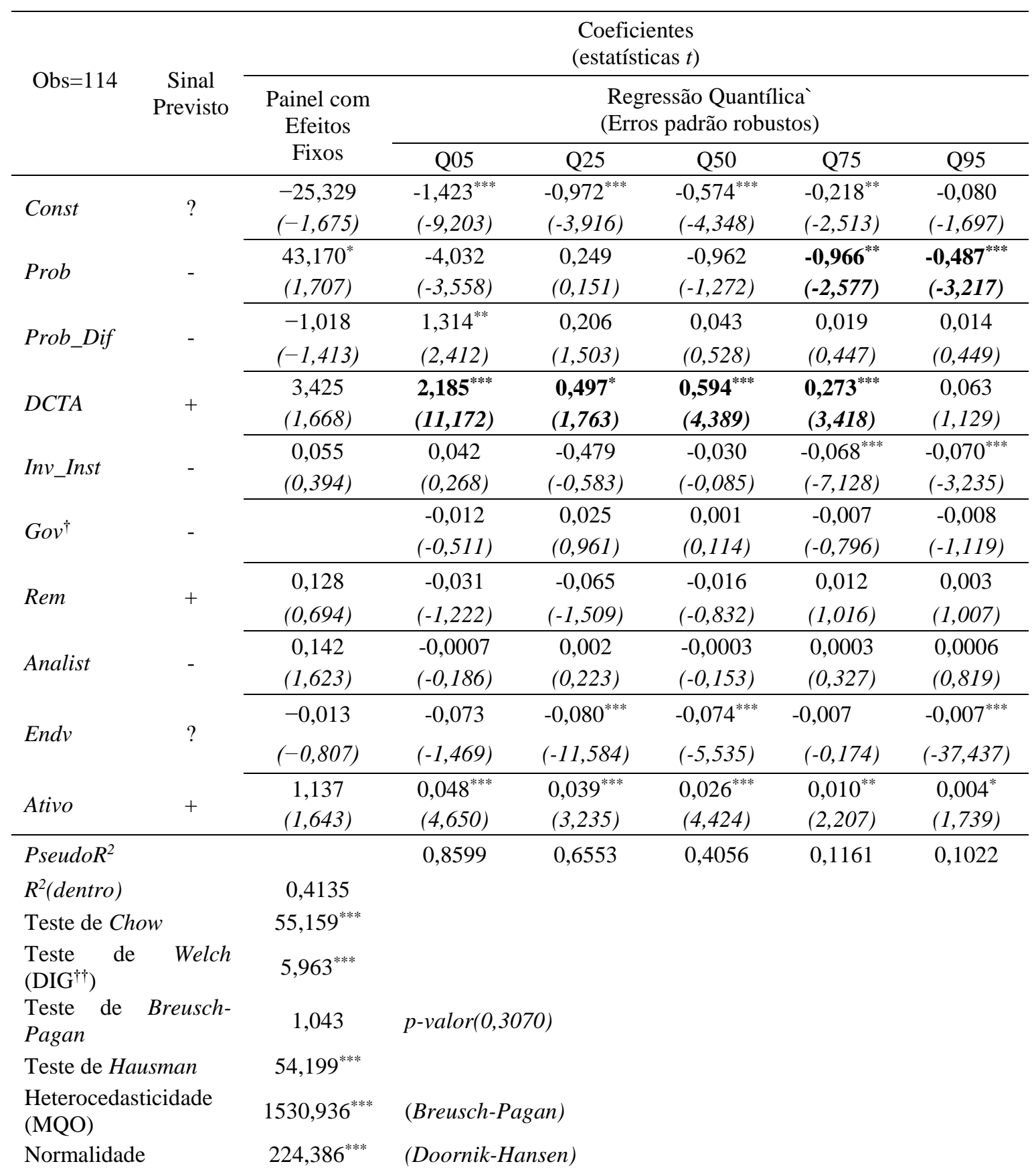

${ }^{\dagger}$ A variável Gov foi omitida na estimação do painel com efeitos fixos em razão de colinearidade exata.

${ }^{\dagger}$ DIG - Diferenciação de Interceptos de Grupos

$*, * * \mathrm{e} * * *$ indicam a significância estatística bicaudal a $10 \%, 5 \%$; e $1 \%$, respectivamente.

Fonte: dados da pesquisa 


\section{APÊNDICE C: RESULTADOS DAS ESTIMAÇÕES DO MODELO (34)}

$$
\begin{aligned}
\text { ESC }_{i t}=\beta_{0}+ & \beta_{1} \text { Prob }_{i t}+\beta_{2} \text { Prob_Dif }_{i t} \\
+ & \lambda_{1} \text { GOVERN }_{i t}+\lambda_{2} \text { Prob }_{i t} \times \text { GOVERN }_{i t}+\lambda_{3} \text { Prob_Dif }_{i t} \times \text { GOVERN }_{i t} \\
& +\delta_{1} \text { DCT }_{i t}+\delta_{2} \text { End }_{i t}+\delta_{3} \text { Ativo }_{i t}+\delta_{4} d 2011+\delta_{5} d 2012+\delta_{6} d 2013+\varepsilon_{i t}
\end{aligned}
$$

\begin{tabular}{|c|c|c|c|c|c|}
\hline \multirow{2}{*}{$\mathrm{Obs}=846$} & \multicolumn{5}{|c|}{ Coeficientes } \\
\hline & Q05 & Q25 & Q50 & Q75 & Q95 \\
\hline Prob & $\begin{array}{c}-1,588 \\
(-1,376) \\
\end{array}$ & $\begin{array}{l}1,783^{* * *} \\
(4,552) \\
\end{array}$ & $\begin{array}{c}3,159^{* * *} \\
(6,124) \\
\end{array}$ & $\begin{array}{c}4,483^{* * *} \\
(6,215) \\
\end{array}$ & $\begin{array}{c}6,908^{* * *} \\
(5,454)\end{array}$ \\
\hline Prob_Dif & $\begin{array}{c}0,359^{* * *} \\
(2,816)\end{array}$ & $\begin{array}{c}-0,048 \\
(-1,120)\end{array}$ & $\begin{array}{c}-0,033 \\
(-0,590)\end{array}$ & $\begin{array}{c}-0,235^{\text {*** }} \\
(-2,950)\end{array}$ & $\begin{array}{l}-0,915^{\text {*** }} \\
(-6,527)\end{array}$ \\
\hline $\operatorname{Inv}$ & $\begin{array}{c}-0,025 \\
(-0,319)\end{array}$ & $\begin{array}{c}0,049^{*} \\
(1,802)\end{array}$ & $\begin{array}{c}0,109^{* * *} \\
(3,052)\end{array}$ & $\begin{array}{c}0,094^{*} \\
(1,870)\end{array}$ & $\begin{array}{c}0,135 \\
(1,531)\end{array}$ \\
\hline Prob $x$ Inv & $\begin{array}{c}2,285 \\
(1,388) \\
\end{array}$ & $\begin{array}{c}0,117 \\
(0,210) \\
\end{array}$ & $\begin{array}{c}-0,479 \\
(-0,651)\end{array}$ & $\begin{array}{c}-0,910 \\
(-0,884)\end{array}$ & $\begin{array}{l}-5,046 \\
(-2,792)\end{array}$ \\
\hline Prob_Dif $x$ Inv & $\begin{array}{c}-0,203 \\
(-1,146) \\
\end{array}$ & $\begin{array}{c}-0,093 \\
(-1,557) \\
\end{array}$ & $\begin{array}{l}-0,177^{* *} \\
(-2,231)\end{array}$ & $\begin{array}{c}-0,022 \\
(-0,199) \\
\end{array}$ & $\begin{array}{c}0,327^{*} \\
(1,680)\end{array}$ \\
\hline Pseudo $R^{2}$ & 0,4533 & 0,1990 & 0,1118 & 0,1182 & 0,3483 \\
\hline
\end{tabular}

Tabela 25 - Presença de Investidores Institucionais (GOVERN) - Equação (34)

Painel A - Amostra Total

Painel B - Decisão 1

\begin{tabular}{lccccc}
\hline \multirow{2}{*}{ Obs=384 } & \multicolumn{5}{c}{ Coeficientes } \\
\cline { 2 - 6 } & $\mathrm{Q} 05$ & $\mathrm{Q} 25$ & $\mathrm{Q} 50$ & $\mathrm{Q} 75$ & $\mathrm{Q} 95$ \\
\hline \multirow{2}{*}{ Prob } & $0,194^{* *}$ & 1,259 & $3,418^{* * *}$ & $5,502^{* * *}$ & $2,055^{* * *}$ \\
& $(2,535)$ & $(1,389)$ & $(5,171)$ & $(4,847)$ & $(5,106)$ \\
\cline { 2 - 6 } Prob_Dif & $0,576^{* * *}$ & $-0,008$ & $-0,008$ & $-0,269^{* *}$ & $-0,502^{* * *}$ \\
& $(66,422)$ & $(-0,082)$ & $(-0,115)$ & $(-2,088)$ & $(-10,995)$ \\
\cline { 2 - 6 } Inv & $0,130^{* * *}$ & 0,0516 & $0,155^{* * *}$ & 0,125 & $0,117^{* *}$ \\
& $(24,049)$ & $(0,807)$ & $(3,323)$ & $(1562)$ & $(4,121)$ \\
ProbxInv & 1,030 & 0,921 & $-0,491$ & $-1,521$ & $-0,386$ \\
& $(9,396)$ & $(0,709)$ & $(-0,518)$ & $(-0,935)$ & $(-0,669)$ \\
\hline Prob_Difx Inv & $-0,583^{* * *}$ & $-0,237^{*}$ & $-0,353^{* * *}$ & $-0,054$ & $-0,311^{* * *}$ \\
$(-49,604)$ & $(-1,701)$ & $(-3,479)$ & $(-0,311)$ & $(-5,024)$ \\
\hline Pseudo R $R^{2}$ & 0,6239 & 0,2940 & 0,1503 & 0,1231 & 0,2415 \\
\hline
\end{tabular}


Painel C - Decisão 2

\begin{tabular}{lccccc}
\hline \multirow{2}{*}{ Obs=300 } & \multicolumn{5}{c}{ Coeficientes } \\
\cline { 2 - 6 } & $\mathrm{Q} 05$ & $\mathrm{Q} 25$ & $\mathrm{Q} 50$ & $\mathrm{Q} 75$ & $\mathrm{Q} 95$ \\
\hline \multirow{2}{*}{ Prob } & $-7,657^{* * *}$ & $-0,293$ & $-0,417$ & $-0,028$ & $-0,031$ \\
& $(-4,855)$ & $(-0,452)$ & $(-1,297)$ & $(-0,128)$ & $(-0,201)$ \\
\cline { 2 - 6 } Prob_Dif & 0,233 & $-0,006$ & 0,009 & 0,010 & $-0,010$ \\
& $(1,480)$ & $(-0,101)$ & $(0,285)$ & $(0,447)$ & $(-0,681)$ \\
\cline { 2 - 6 } Inv & $-0,619^{* * *}$ & $-0,065$ & 0,020 & 0,024 & 0,010 \\
& $(-5,171)$ & $(-1,335)$ & $(0,843)$ & $(1,436)$ & $(0,909)$ \\
\cline { 2 - 6 } Probx Inv & $5,423^{* *}$ & $-0,728$ & $-0,684$ & $-0,249$ & $-0,371$ \\
& $(2,151)$ & $(-0,704)$ & $(-1,333)$ & $(-0,704)$ & $(-1,515)$ \\
\cline { 2 - 6 } Prob_Difx Inv & $1,555^{* * *}$ & $0,275^{* *}$ & $-0,036$ & $-0,088^{* *}$ & $-0,002$ \\
& $(5,638)$ & $(2,427)$ & $(-0,642)$ & $(-2,279)$ & $(-0,080)$ \\
\hline Pseudo R $R^{2}$ & 0,7154 & 0,4546 & 0,2832 & 0,0642 & 0,0578 \\
\hline
\end{tabular}

Painel D - Decisão 3

\begin{tabular}{lccccc}
\hline \multirow{2}{*}{ Obs=270 } & \multicolumn{5}{c}{ Coeficientes } \\
\cline { 2 - 6 } & Q05 & Q25 & Q50 & Q75 & Q95 \\
\hline \multirow{2}{*}{ Prob } & $0,764^{* * *}$ & $2,699^{* * *}$ & $4,741^{* * *}$ & $3,927^{* * *}$ & $11,777^{* * *}$ \\
& $(475.450)$ & $(5,105)$ & $(7,238)$ & $(3,267)$ & $\left(3,40 \times 10^{7}\right)$ \\
\cline { 2 - 6 } Prob_Dif & $-0,031^{* * *}$ & $-0,106^{*}$ & $-0,221^{* * *}$ & $-0,446^{* * *}$ & $-0,169^{* * *}$ \\
& $(-162.021)$ & $(-1,668)$ & $(2,792)$ & $(-3,076)$ & $\left(-4,06 \times 10^{7}\right)$ \\
\cline { 2 - 6 } Inv & $0,058^{* * *}$ & $0,073^{* *}$ & $0,128^{* * *}$ & 0,022 & 0,515 \\
\multirow{3}{*}{ ProbxInv } & $(542.751)$ & $(2,068)$ & $(2,919)$ & $(0,274)$ & $\left(2,23 \times 10^{7}\right)$ \\
\cline { 2 - 6 } Prob_Dif x Inv & $-1,049^{* * *}$ & $-1,721^{* *}$ & $-2,255^{* *}$ & $-1,269$ & $-10,460^{* * * *}$ \\
\cline { 2 - 6 } & $(-476.484)$ & $(-2,376)$ & $(-2,513)$ & $(-0,771)$ & $\left(-2,21 \times 10^{7}\right)$ \\
\hline \multirow{2}{*}{ Pseudo R $R^{2}$} & $0,003^{* * *}$ & 0,072 & $-0,037$ & 0,183 & $-0,880^{* * *}$ \\
& $(11.731,9)$ & $(0,917)$ & $(-0,385)$ & $(1,020)$ & $\left(-1,70 \times 10^{7}\right)$ \\
\hline
\end{tabular}

Painel E - Decisão 4

\begin{tabular}{lccccc}
\hline \multirow{2}{*}{ Obs=114 } & \multicolumn{5}{c}{ Coeficientes } \\
\cline { 2 - 6 } & $\mathrm{Q} 05$ & $\mathrm{Q} 25$ & $\mathrm{Q} 50$ & $\mathrm{Q} 75$ & $\mathrm{Q} 95$ \\
\hline \multirow{2}{*}{ Prob } & $\begin{array}{c}-6,848^{* * *} \\
(-4,274)\end{array}$ & $\begin{array}{c}-1,191^{* * *} \\
(-19,461)\end{array}$ & $\begin{array}{c}-1,117^{* * *} \\
(-6,887)\end{array}$ & $\begin{array}{c}-0,809^{* * *} \\
(-926,230)\end{array}$ & $\begin{array}{c}-0,554^{* * *} \\
(-2,878)\end{array}$ \\
\cline { 2 - 6 } Prob_Dif & $\begin{array}{c}1,018^{* * *} \\
(6,382)\end{array}$ & $\begin{array}{c}0,264^{* * *} \\
(43,336)\end{array}$ & $\begin{array}{c}-0,087^{* * *} \\
(-5,385)\end{array}$ & $\begin{array}{c}0,031^{* * *} \\
(361,395)\end{array}$ & $\begin{array}{c}0,038^{* * * *} \\
(1,989)\end{array}$ \\
\cline { 2 - 6 } Inv & $\begin{array}{c}0,097 \\
(0,537)\end{array}$ & $\begin{array}{c}-0,295^{* * *} \\
(-42,761)\end{array}$ & $\begin{array}{c}-0,135^{* * *} \\
(-7,407)\end{array}$ & $\begin{array}{c}-0,009^{* * *} \\
(-90,448)\end{array}$ & $\begin{array}{c}-0,026 \\
(-1,216)\end{array}$ \\
\cline { 2 - 6 } ProbxInv & $\begin{array}{c}-0,625 \\
(-0,193)\end{array}$ & $\begin{array}{c}-2,020^{* * *} \\
(-16,360)\end{array}$ & $\begin{array}{c}-0,396 \\
(-1,211)\end{array}$ & $\begin{array}{c}0,397^{* * *} \\
(225,555)\end{array}$ & $\begin{array}{c}0,540 \\
(1,392)\end{array}$ \\
\cline { 2 - 6 } Prob_Difx Inv & $\begin{array}{c}-0,345 \\
(-0,881)\end{array}$ & $\begin{array}{c}1,237^{* * *} \\
(82,716)\end{array}$ & $\begin{array}{c}0,469^{* * *} \\
(11,826)\end{array}$ & $\begin{array}{c}-0,015^{* * *} \\
(-71,968)\end{array}$ & $\begin{array}{c}-0,018 \\
(-0,389)\end{array}$ \\
\hline Pseudo R & 0,8462 & 0,6190 & 0,3770 & 0,0940 & 0,0951 \\
\hline
\end{tabular}

Fonte: dados da pesquisa 
Tabela 26 - Adesão aos Segmentos de Governança Corporativa da BM\&FBovespa (GOVERN) Equação (34)

Painel A - Amostra Total

\begin{tabular}{lccccc}
\hline \multirow{2}{*}{ Obs=846 } & \multicolumn{5}{c}{ Coeficientes } \\
\cline { 2 - 6 } & $\mathrm{Q} 05$ & $\mathrm{Q} 25$ & $\mathrm{Q} 50$ & $\mathrm{Q} 75$ & $\mathrm{Q} 95$ \\
\hline \multirow{2}{*}{ Prob } & $\begin{array}{c}-1,013 \\
\text { (-1,177) }\end{array}$ & $\begin{array}{c}3,867^{* * *} \\
(8,547)\end{array}$ & $\begin{array}{c}4,327^{* * *} \\
(12,758)\end{array}$ & $\begin{array}{c}6,533^{* * *} \\
(8,855)\end{array}$ & $\begin{array}{c}12,318^{* * *} \\
(5,793)\end{array}$ \\
\cline { 2 - 6 } Prob_Dif & $\begin{array}{c}0,457 \\
(4,846)\end{array}$ & $\begin{array}{c}-0,024 \\
(-0,487)\end{array}$ & $\begin{array}{c}-0,112 \\
(-3,008)\end{array}$ & $\begin{array}{c}-0,178^{* *} \\
(-2,201)\end{array}$ & $\begin{array}{c}-0,740 \\
(-3,176)\end{array}$ \\
\cline { 2 - 6 } Gov & $0,151^{* *}$ & $0,169^{* * *}$ & $0,172^{* * *}$ & $0,224^{* * *}$ & $0,407^{* *}$ \\
& $(2,296)$ & $(4,908)$ & $(6,635)$ & $(3,972)$ & $(2,509)$ \\
\cline { 2 - 6 } ProbxGov & 0,397 & $-2,500^{* * *}$ & $-2,278^{* * *}$ & $-3,642^{* * *}$ & $-12,138^{* * *}$ \\
Prob_Difx Gov & $(0,306)$ & $(-3,667)$ & $(-4,458)$ & $(-3,277)$ & $(-3,789)$ \\
\hline & $-0,564^{* * *}$ & $-0,108$ & $-0,153^{* *}$ & $-0,181$ & $-0,175$ \\
$(-3,541)$ & $(-1,294)$ & $(-2,437)$ & $(-1,330)$ & $(-0,444)$ \\
\hline Pseudo R & 0,4717 & 0,2013 & 0,1122 & 0,1224 & 0,3576 \\
\hline
\end{tabular}

Painel B - Decisão 1

\begin{tabular}{lccccc}
\hline \multirow{2}{*}{ Obs=384 } & \multicolumn{5}{c}{ Coeficientes } \\
\cline { 2 - 6 } & Q05 & Q25 & Q50 & Q75 & Q95 \\
\hline \multirow{2}{*}{ Prob } & $0,579^{* * *}$ & $3,920^{* * *}$ & $5,1473^{* * *}$ & $6,729^{* * *}$ & $17,214^{* * *}$ \\
& $(4,387)$ & $(5,660)$ & $(7,786)$ & $(9,025)$ & $(5,674)$ \\
\cline { 2 - 6 } Prob_Dif & $0,488^{* * * *}$ & $-0,051$ & $-0,119^{*}$ & $-0,319^{* * * *}$ & $-0,350$ \\
& $(34,076)$ & $(-0,682)$ & $(-1,667)$ & $(-3,945)$ & $(-1,063)$ \\
\cline { 2 - 6 } Gov & $0,249^{* * *}$ & $0,198^{* * *}$ & $0,234^{* * *}$ & $0,213^{* * *}$ & $0,660^{* * *}$ \\
& $(25,373)$ & $(3,850)$ & $(4,752)$ & $(3,845)$ & $(2,926)$ \\
\cline { 2 - 6 } Probx Gov & $-0,614^{* * *}$ & $-2,334^{* *}$ & $-2,479^{* *}$ & $-3,336^{* * *}$ & $-14,969^{* * *}$ \\
& $(-3,218)$ & $(-2,331)$ & $(-2,593)$ & $(-3,094)$ & $(-3,412)$ \\
\cline { 2 - 6 } Prob_Difx Gov & $-0,675^{* * *}$ & $-0,235^{*}$ & $-0,334^{* * *}$ & $-0,165$ & $-0,868$ \\
& $(-28,394)$ & $(-1,889)$ & $(-2,809)$ & $(-1,229)$ & $(-1,590)$ \\
\hline Pseudo R $R^{2}$ & 0,6307 & 0,2941 & 0,1467 & 0,1248 & 0,2433 \\
\hline
\end{tabular}

Painel C - Decisão 2

\begin{tabular}{lccccc}
\hline \multirow{2}{*}{ Obs=300 } & \multicolumn{5}{c}{ Coeficientes } \\
\cline { 2 - 6 } & $\mathrm{Q} 05$ & $\mathrm{Q} 25$ & $\mathrm{Q} 50$ & $\mathrm{Q} 75$ & $\mathrm{Q} 95$ \\
\hline \multirow{2}{*}{ Prob } & $-8,252^{* * *}$ & 0,250 & 0,121 & 0,142 & $-0,199$ \\
& $(-73,729)$ & $(0,288)$ & $(0,371)$ & $(0,825)$ & $(-1,478)$ \\
\cline { 2 - 6 } Prob_Dif & $0,887^{* * *}$ & 0,131 & $-0,014$ & 0,002 & 0,004 \\
& $(81,739)$ & $(1,562)$ & $(-0,453)$ & $(0,130)$ & $(0,357)$ \\
\cline { 2 - 6 } Gov & $-0,068^{* * *}$ & 0,107 & 0,033 & 0,025 & $-0,006$ \\
& $(-6,872)$ & $(1,401)$ & $(1,156)$ & $(1,677)$ & $(-0,530)$ \\
\cline { 2 - 6 } ProbxGov & $6,497^{* * *}$ & $-1,697$ & $-1,251^{* *}$ & $-0,556^{* * *}$ & 0,089 \\
& $(37,755)$ & $(-1,272)$ & $(-2,499)$ & $(-2,105)$ & $(0,433)$ \\
Prob_Difx Gov & $-0,794^{* * *}$ & $-0,095$ & 0,020 & $-0,018$ & $-0,001$ \\
& $(-30,270)$ & $(-0,469)$ & $(0,265)$ & $(-0,459)$ & $(0,049)$ \\
\hline \multirow{2}{*}{ Pseudo R $R^{2}$} & 0,7199 & 0,4659 & 0,2832 & 0,0607 & 0,0537 \\
\hline
\end{tabular}


Painel D - Decisão 3

\begin{tabular}{lccccc}
\hline \multirow{2}{*}{ Obs=270 } & \multicolumn{5}{c}{ Coeficientes } \\
\cline { 2 - 6 } & Q05 & Q25 & Q50 & Q75 & Q95 \\
\hline \multirow{2}{*}{ Prob } & $\begin{array}{c}0,485^{* * *} \\
(2,000)\end{array}$ & $\begin{array}{c}2,644^{* * *} \\
(11,077)\end{array}$ & $\begin{array}{c}5,118^{* * *} \\
(7,263)\end{array}$ & $\begin{array}{c}4,309^{* * *} \\
(4,574)\end{array}$ & $\begin{array}{c}18,933^{* * *} \\
(11,839)\end{array}$ \\
\cline { 2 - 6 } Prob_Dif & $\begin{array}{c}-0,024 \\
(-0,872)\end{array}$ & $\begin{array}{c}-0,072^{* *} \\
(-2,661)\end{array}$ & $\begin{array}{c}-0,254^{* * *} \\
(-3,166)\end{array}$ & $\begin{array}{c}-0,336 \\
(-3,127)\end{array}$ & $\begin{array}{c}-0,084 \\
(-0,460)\end{array}$ \\
\cline { 2 - 6 } Gov & 0,018 & $0,058^{* * *}$ & $0,172^{* * *}$ & 0,133 & 0,648 \\
& $(1,066)$ & $(3,495)$ & $(3,513)$ & $(2,027)$ & $(5,827)$ \\
Probx_Gov & $-0,352$ & $-1,389^{* * *}$ & $-3,289^{* * *}$ & $-1,705$ & $-16,647^{* * *}$ \\
Prob_Difx & $(-1,041)$ & $(-4,172)$ & $(-3,346)$ & $(-1,298)$ & $(-7,463)$ \\
Gov & $-0,004$ & 0,039 & $-0,043$ & $-0,257$ & $-0,864^{* * *}$ \\
\hline Pseudo R $R^{2}$ & $(-0,103)$ & $(0,966)$ & $(-0,362)$ & $(-1,612)$ & $(-3,188)$ \\
\hline
\end{tabular}

Painel E - Decisão 4

\begin{tabular}{lccccc}
\hline \multirow{2}{*}{ Obs=114 } & \multicolumn{5}{c}{ Coeficientes } \\
\cline { 2 - 6 } & $\mathrm{Q} 05$ & $\mathrm{Q} 25$ & $\mathrm{Q} 50$ & $\mathrm{Q} 75$ & $\mathrm{Q} 95$ \\
\hline \multirow{2}{*}{ Prob } & $-5,200^{* * *}$ & 0,102 & 0,668 & $-0,548$ & 0,076 \\
& $(-7,531)$ & $(0,137)$ & $(1,076)$ & $(-1,009)$ & $(0,563)$ \\
\cline { 2 - 6 } Prob_Dif & $1,374^{* * *}$ & $0,341^{* * *}$ & $-0,092$ & 0,010 & $0,043^{* * * *}$ \\
& $(21,237)$ & $(4,877)$ & $(-1,590)$ & $(0,192)$ & $(3,426)$ \\
\cline { 2 - 6 } Gov & $0,251^{* * *}$ & 0,153 & 0,053 & 0,009 & $0,034^{* *}$ \\
& $(2,915)$ & $(1,642)$ & $(0,684)$ & $(0,128)$ & $(1,996)$ \\
Probx_Gov & $4,605^{* * *}$ & $-1,546$ & $-2,009^{*}$ & $-0,296$ & $-0,213$ \\
Prob_Dif $x$ & $(3,848)$ & $(-1,195)$ & $(-1,868)$ & $(-0,314)$ & $(-0,903)$ \\
\cline { 2 - 6 } Gov & $-1,453^{* * *}$ & $-0,370$ & 0,073 & $-0,021$ & $-0,124$ \\
\hline \multirow{2}{*}{ Pseudo $R^{2}$} & $(-5,817)$ & $(-1,371)$ & $(0,327)$ & $(-0,107)$ & $(-2,521)$ \\
\hline
\end{tabular}

Fonte: dados da pesquisa 


\section{APÊNDICE D: RESULTADOS DAS ESTIMAÇÕES DO MODELO (33) - Variável}

Dependente - DCTA

$$
\begin{aligned}
\text { DCTA }_{i t}=\beta_{0} & +\beta_{1} \text { Prob }_{i t}+\beta_{2} \text { Prob_Dif }_{i t}+\beta_{3} \text { ESCSC }_{i t} \\
& +\lambda_{1} \text { Inv }_{-} \text {Inst }_{i t}+\lambda_{2} \text { Gov }_{i t}+\lambda_{3} \text { Rem }_{i t}+\lambda_{4} \text { Big }_{i t} \\
& \quad+\delta_{1} \text { Ativo }_{i t}+\delta_{2} d 2011+\delta_{3} d 2012+\delta_{4} d 2013+v_{i t}
\end{aligned}
$$

\begin{tabular}{|c|c|c|c|c|c|c|c|}
\hline \multirow{3}{*}{ Obs $=846$} & \multirow{3}{*}{$\begin{array}{l}\text { Sinal } \\
\text { Previsto }\end{array}$} & \multicolumn{6}{|c|}{$\begin{array}{l}\text { Coeficientes } \\
\text { (estatísticas } t)\end{array}$} \\
\hline & & \multirow{2}{*}{$\begin{array}{l}\text { Painel com } \\
\text { Efeitos } \\
\text { Aleatórios }\end{array}$} & \multicolumn{5}{|c|}{$\begin{array}{l}\text { Regressão Quantílica } \\
\text { (Erros padrão robustos) }\end{array}$} \\
\hline & & & Q05 & Q25 & Q50 & Q75 & Q95 \\
\hline \multirow{2}{*}{ Const } & \multirow{2}{*}{ ? } & 0,038 & $-0,052$ & 0,023 & $0,044^{* * *}$ & $0,083^{* *}$ & $0,153^{* * *}$ \\
\hline & & $(1,097)$ & $(-1,309)$ & $(0,821)$ & $(2,678)$ & $(2,485)$ & $(3,899)$ \\
\hline Prob & - & $\begin{array}{c}-0,008 \\
(-0,045)\end{array}$ & $\begin{array}{c}-0,302 \\
(-1,355)\end{array}$ & $\begin{array}{l}-0,176 \\
(-1,110)\end{array}$ & $\begin{array}{c}-0,122 \\
(-1,326)\end{array}$ & $\begin{array}{c}-0,026 \\
(-0,139)\end{array}$ & $\begin{array}{l}0,561^{* *} \\
(2,562)\end{array}$ \\
\hline Prob_Dif & - & $\begin{array}{l}-0,0005 \\
(-0,023)\end{array}$ & $\begin{array}{l}0,091^{* * *} \\
(3,587)\end{array}$ & $\begin{array}{c}0,017 \\
(0,926)\end{array}$ & $\begin{array}{c}0,013 \\
(1,244)\end{array}$ & $\begin{array}{c}-0,003 \\
(-0,126) \\
\end{array}$ & $\begin{array}{l}-0,085^{* * * *} \\
(-3,418) \\
\end{array}$ \\
\hline ESC & + & $\begin{array}{c}0,006 \\
(1,481) \\
\end{array}$ & $\begin{array}{c}0,009 \\
(1,296)\end{array}$ & $\begin{array}{c}0,001 \\
(0,307)\end{array}$ & $\begin{array}{l}0,0004 \\
(0,156) \\
\end{array}$ & $\begin{array}{c}0,004 \\
(0,689) \\
\end{array}$ & $\begin{array}{l}0,017^{* *} \\
(2,535)\end{array}$ \\
\hline Inv_Inst & - & $\begin{array}{c}0,007 \\
(0,386)\end{array}$ & $\begin{array}{c}0,005 \\
(0,220)\end{array}$ & $\begin{array}{l}-0,018 \\
(-1,061)\end{array}$ & $\begin{array}{c}0,006 \\
(0,669)\end{array}$ & $\begin{array}{c}0,026 \\
(1,330)\end{array}$ & $\begin{array}{l}-0,030 \\
(-1,318)\end{array}$ \\
\hline Gov & - & $\begin{array}{l}0,017^{* * *} \\
(2,435)\end{array}$ & $\begin{array}{c}0,004 \\
(0,548)\end{array}$ & $\begin{array}{c}0,006 \\
(1,027)\end{array}$ & $\begin{array}{c}0,003 \\
(0,955)\end{array}$ & $\begin{array}{c}0,008 \\
(1,187)\end{array}$ & $\begin{array}{l}0,040^{* * * *} \\
(5,089)\end{array}$ \\
\hline Rem & + & $\begin{array}{l}-0,012^{* *} \\
(-1,974)\end{array}$ & $\begin{array}{l}-0,019^{* *} \\
(-2,536)\end{array}$ & $\begin{array}{l}-0,008 \\
(-1,491)\end{array}$ & $\begin{array}{c}-0,002 \\
(-0,674)\end{array}$ & $\begin{array}{l}-0,0003 \\
(-0,048)\end{array}$ & $\begin{array}{c}-0,011 \\
(-1,448)\end{array}$ \\
\hline Big4 & - & $\begin{array}{c}-0,004 \\
(-1,016)\end{array}$ & $\begin{array}{l}-0,008 \\
(-1,320)\end{array}$ & $\begin{array}{c}-0,001 \\
(-0,372)\end{array}$ & $\begin{array}{l}-0,0004 \\
(-0,176)\end{array}$ & $\begin{array}{c}0,004 \\
(0,862)\end{array}$ & $\begin{array}{l}-0,011^{*} \\
(-1,883)\end{array}$ \\
\hline Ativo & + & $\begin{array}{l}-0,002 \\
(-1,014)\end{array}$ & $\begin{array}{l}-0,0002 \\
(-0,123)\end{array}$ & $\begin{array}{c}-0,002 \\
(-1,498)\end{array}$ & $\begin{array}{l}-0,002^{* *} \\
(-2,668)\end{array}$ & $\begin{array}{l}-0,003^{*} \\
(-1,869)\end{array}$ & $\begin{array}{l}-0,003^{*} \\
(-1,918)\end{array}$ \\
\hline \multicolumn{2}{|c|}{ Dummies temporais } & Não & & & Sim & & \\
\hline \multicolumn{2}{|l|}{ PseudoR ${ }^{2}$} & & 0,0438 & 0,0111 & 0,0058 & 0,0159 & 0,0958 \\
\hline \multicolumn{2}{|l|}{$\begin{array}{l}R^{2} \\
\left(R^{2} \text { ajust. }\right)\end{array}$} & $\begin{array}{c}0,0206 \\
(0,0113)\end{array}$ & & & & & \\
\hline \multicolumn{2}{|c|}{ Teste de Chow } & $50,553^{* * *}$ & & & & & \\
\hline \multicolumn{2}{|c|}{$\begin{array}{l}\text { Teste de Breusch- } \\
\text { Pagan }\end{array}$} & $128,272^{* * *}$ & & & & & \\
\hline \multicolumn{2}{|c|}{ Teste de Hausman } & 4,135 & \multicolumn{5}{|c|}{$p$-valor $(0,7641)$} \\
\hline \multicolumn{2}{|c|}{$\begin{array}{l}\text { Heterocedasticidade } \\
\text { (MQO) }\end{array}$} & $169,978^{* * *}$ & \multicolumn{2}{|c|}{ (Breusch-Pagan) } & & & \\
\hline
\end{tabular}

Tabela 27 - Resultados para a Amostra Total - Equação (33): variável dependente DCTA

$*, * * \mathrm{e}^{* * *}$ indicam a significância estatística bicaudal a $10 \%, 5 \%$; e $1 \%$, respectivamente.

Fonte: dados da pesquisa 
Tabela 28 - Resultados para a Decisão 1 - Equação (33): variável dependente DCTA

\begin{tabular}{|c|c|c|c|c|c|c|c|}
\hline \multirow{3}{*}{ Obs $=384$} & \multirow{3}{*}{$\begin{array}{c}\text { Sinal } \\
\text { Previsto }\end{array}$} & \multicolumn{6}{|c|}{$\begin{array}{l}\text { Coeficientes } \\
\text { (estatísticas } t \text { ) }\end{array}$} \\
\hline & & \multirow{2}{*}{$\begin{array}{c}\text { Painel com } \\
\text { Efeitos } \\
\text { Aleatórios }\end{array}$} & \multicolumn{5}{|c|}{$\begin{array}{l}\text { Regressão Quantílica } \\
\text { (Erros padrão robustos) }\end{array}$} \\
\hline & & & Q05 & Q25 & Q50 & Q75 & Q95 \\
\hline Const & $?$ & $\begin{array}{l}0,099^{* *} \\
(2,196)\end{array}$ & $\begin{array}{l}0,0002 \\
(0,045)\end{array}$ & $\begin{array}{c}0,006 \\
(0,464) \\
\end{array}$ & $\begin{array}{l}0,039 \\
(1,372) \\
\end{array}$ & $\begin{array}{c}0,043 \\
(1,300) \\
\end{array}$ & $\begin{array}{c}0,286^{* * *} \\
(4,887)\end{array}$ \\
\hline Prob & - & $\begin{array}{c}-0,082 \\
(-0,370)\end{array}$ & $\begin{array}{c}0,004 \\
(0,161)\end{array}$ & $\begin{array}{l}0,139^{* *} \\
(2,062)\end{array}$ & $\begin{array}{c}0,033 \\
(0,229)\end{array}$ & $\begin{array}{c}0,534^{* * *} \\
(3,081)\end{array}$ & $\begin{array}{l}0,658^{* *} \\
(2,166)\end{array}$ \\
\hline Prob_Dif & - & $\begin{array}{c}-0,032 \\
(-1,264)\end{array}$ & $\begin{array}{l}0,009^{* *} \\
(2,886)\end{array}$ & $\begin{array}{c}0,007 \\
(0,925)\end{array}$ & $\begin{array}{c}-0,005 \\
(-0,322)\end{array}$ & $\begin{array}{c}-0,059^{* * *} \\
(-2,895)\end{array}$ & $\begin{array}{l}-0,144^{* * *} \\
(-3,998)\end{array}$ \\
\hline$E S C$ & + & $\begin{array}{c}0,006 \\
(1,460)\end{array}$ & $\begin{array}{l}0,0001 \\
(0,174)\end{array}$ & $\begin{array}{l}0,00007 \\
(-0,045)\end{array}$ & $\begin{array}{c}0,002 \\
(0,618)\end{array}$ & $\begin{array}{c}0,006 \\
(1,594) \\
\end{array}$ & $\begin{array}{c}0,026^{* * *} \\
(3,509)\end{array}$ \\
\hline Inv_Inst & - & $\begin{array}{c}-0,006 \\
(-0,340)\end{array}$ & $\begin{array}{c}0,004 \\
(1,489)\end{array}$ & $\begin{array}{c}-0,006 \\
(-0,902)\end{array}$ & $\begin{array}{c}0,016 \\
(1,105)\end{array}$ & $\begin{array}{c}-0,018 \\
(-1,033)\end{array}$ & $\begin{array}{c}-0,004 \\
(-0,143)\end{array}$ \\
\hline Gov & - & $\begin{array}{c}0,011 \\
(1,200)\end{array}$ & $\begin{array}{c}0,001 \\
(1,421)\end{array}$ & $\begin{array}{l}0,005^{* *} \\
(2,095)\end{array}$ & $\begin{array}{c}0,009^{*} \\
(1,770)\end{array}$ & $\begin{array}{c}0,033^{* * *} \\
(5,126)\end{array}$ & $\begin{array}{l}-0,025^{* *} \\
(-2,205)\end{array}$ \\
\hline Rem & + & $\begin{array}{c}0,006 \\
(0,693)\end{array}$ & $\begin{array}{l}-0,0008 \\
(-0,727)\end{array}$ & $\begin{array}{l}0,0004 \\
(0,155)\end{array}$ & $\begin{array}{c}0,002 \\
(0,375)\end{array}$ & $\begin{array}{c}-0,002 \\
(-0,248)\end{array}$ & $\begin{array}{c}0,049^{* * *} \\
(4,230)\end{array}$ \\
\hline Big4 & - & $\begin{array}{c}-0,006 \\
(-0,984)\end{array}$ & $\begin{array}{l}-0,0003 \\
(-0,365) \\
\end{array}$ & $\begin{array}{c}0,001 \\
(0,669) \\
\end{array}$ & $\begin{array}{l}-0,0008 \\
(-0,193) \\
\end{array}$ & $\begin{array}{c}0,001 \\
(0,336)\end{array}$ & $\begin{array}{l}-0,017^{* *} \\
(-2,027)\end{array}$ \\
\hline Ativo & + & $\begin{array}{c}-0,003 \\
(-1,249) \\
\end{array}$ & $\begin{array}{l}-0,00005 \\
(-0,210) \\
\end{array}$ & $\begin{array}{l}-0,0004 \\
(-0,643) \\
\end{array}$ & $\begin{array}{l}-0,0008 \\
(-0,602) \\
\end{array}$ & $\begin{array}{l}-0,0004 \\
(-0,232) \\
\end{array}$ & $\begin{array}{c}-0,008^{* * *} \\
(-2,938)\end{array}$ \\
\hline \multicolumn{2}{|c|}{ Dummies temporais } & Não & \multicolumn{5}{|c|}{ Sim } \\
\hline \multicolumn{2}{|l|}{ PseudoR ${ }^{2}$} & & 0,0175 & 0,0276 & 0,0217 & 0,1053 & 0,1385 \\
\hline \multicolumn{2}{|l|}{$\begin{array}{l}R^{2} \\
\left(R^{2} \text { ajust. }\right)\end{array}$} & $\begin{array}{c}0,0464 \\
(0,0261)\end{array}$ & & & & & \\
\hline \multicolumn{2}{|c|}{ Teste de Chow } & $51,944^{* * *}$ & & & & & \\
\hline \multicolumn{2}{|c|}{$\begin{array}{l}\text { Teste de Breusch- } \\
\text { Pagan }\end{array}$} & $23,011^{* * *}$ & & & & & \\
\hline \multicolumn{2}{|c|}{ Teste de Hausman } & 9,445 & \multicolumn{5}{|c|}{$p$-valor $(0,2222)$} \\
\hline \multicolumn{2}{|c|}{$\begin{array}{l}\text { Heterocedasticidade } \\
\text { (MQO) }\end{array}$} & $208,302^{* * *}$ & \multicolumn{2}{|c|}{ (Breusch-Pagan) } & & & \\
\hline
\end{tabular}

$*, * * \mathrm{e} * * *$ indicam a significância estatística bicaudal a $10 \%, 5 \%$; e $1 \%$, respectivamente.

Fonte: dados da pesquisa 
Tabela 29 - Resultados para a Decisão 2 - Equação (33): variável dependente DCTA

\begin{tabular}{|c|c|c|c|c|c|c|c|}
\hline \multirow{3}{*}{ Obs $=300$} & \multirow{3}{*}{$\begin{array}{c}\text { Sinal } \\
\text { Previsto }\end{array}$} & \multicolumn{6}{|c|}{ Coeficientes } \\
\hline & & \multirow[t]{2}{*}{$\begin{array}{l}\text { MQ2E } \\
\text { (estat.z) }\end{array}$} & \multicolumn{5}{|c|}{$\begin{array}{c}\text { Regressão Quantílica } \\
\text { (Erros padrão robustos) } \\
\text { (estatísticas } t \text { ) }\end{array}$} \\
\hline & & & Q05 & Q25 & Q50 & Q75 & Q95 \\
\hline Const & $?$ & $\begin{array}{c}0,019 \\
(0,347)\end{array}$ & $\begin{array}{l}-0,217^{\text {*** }} \\
(-4,297)\end{array}$ & $\begin{array}{c}0,054 \\
(1,375)\end{array}$ & $\begin{array}{c}0,045^{*} \\
(1,825)\end{array}$ & $\begin{array}{c}0,113^{* * *} \\
(5,868)\end{array}$ & $\begin{array}{c}0,230^{\text {**** }} \\
(5,002)\end{array}$ \\
\hline Prob & - & $\begin{array}{c}-0,388 \\
(-1,239)\end{array}$ & $\begin{array}{l}-1,597^{* * * *} \\
(-5,480)\end{array}$ & $\begin{array}{l}-0,457^{* *} \\
(-1,999)\end{array}$ & $\begin{array}{l}-0,262^{*} \\
(-1,832)\end{array}$ & $\begin{array}{c}-0,008 \\
(-0,074)\end{array}$ & $\begin{array}{c}0,879^{* * *} \\
(3,299)\end{array}$ \\
\hline Prob_Dif & - & $\begin{array}{c}0,017 \\
(0,642) \\
\end{array}$ & $\begin{array}{c}0,029 \\
(0,875)\end{array}$ & $\begin{array}{c}-0,006 \\
(-0,233)\end{array}$ & $\begin{array}{c}0,019 \\
(1,194) \\
\end{array}$ & $\begin{array}{c}0,048^{* * *} \\
(3,829)\end{array}$ & $\begin{array}{c}-0,003 \\
(-0,106) \\
\end{array}$ \\
\hline$E S C$ & + & $\begin{array}{c}-0,012 \\
(-1,120)\end{array}$ & $\begin{array}{c}-0,013 \\
(-1,628) \\
\end{array}$ & $\begin{array}{c}-0,002 \\
(-0,416)\end{array}$ & $\begin{array}{l}-0,0008 \\
(-0,198)\end{array}$ & $\begin{array}{c}0,005 \\
(1,527)\end{array}$ & $\begin{array}{c}0,013^{*} \\
(1,763)\end{array}$ \\
\hline Inv_Inst & - & $\begin{array}{c}-0,009 \\
(-0,433)\end{array}$ & $\begin{array}{c}0,003 \\
(0,119)\end{array}$ & $\begin{array}{c}-0,019 \\
(-0,846)\end{array}$ & $\begin{array}{l}-0,033^{* *} \\
(-2,372)\end{array}$ & $\begin{array}{c}-0,017 \\
(-1,644)\end{array}$ & $\begin{array}{c}-0,017 \\
(-0,648)\end{array}$ \\
\hline Gov & - & $\begin{array}{c}0,025 \\
(1,571)\end{array}$ & $\begin{array}{l}0,028^{* *} \\
(2,472)\end{array}$ & $\begin{array}{c}0,001 \\
(0,135)\end{array}$ & $\begin{array}{c}-0,004 \\
(-0,758)\end{array}$ & $\begin{array}{c}-0,002 \\
(-0,513)\end{array}$ & $\begin{array}{c}0,032^{* * *} \\
(3,060)\end{array}$ \\
\hline Rem & + & $\begin{array}{c}-0,033^{*} \\
(-1,651)\end{array}$ & $\begin{array}{c}-0,047 \\
(-4,546)\end{array}$ & $\begin{array}{c}-0,008 \\
(-0,932)\end{array}$ & $\begin{array}{c}0,001 \\
(0,196)\end{array}$ & $\begin{array}{c}-0,003 \\
(-0,845)\end{array}$ & $\begin{array}{c}0,002 \\
(0,233)\end{array}$ \\
\hline Big4 & - & $\begin{array}{c}-0,009 \\
(-1,279)\end{array}$ & $\begin{array}{c}-0,035^{\text {**** }} \\
(-4,979)\end{array}$ & $\begin{array}{l}-0,012^{* *} \\
(-2,244)\end{array}$ & $\begin{array}{c}-0,005 \\
(-1,447)\end{array}$ & $\begin{array}{l}-0,0005 \\
(-0,182)\end{array}$ & $\begin{array}{c}-0,003 \\
(-0,437)\end{array}$ \\
\hline Ativo & + & $\begin{array}{l}-0,0003 \\
(-0,097) \\
\end{array}$ & $\begin{array}{c}0,012^{* * *} \\
(4,385)\end{array}$ & $\begin{array}{c}-0,002 \\
(-1,078) \\
\end{array}$ & $\begin{array}{c}-0,002 \\
(-1,413) \\
\end{array}$ & $\begin{array}{l}-0,005^{* * *} \\
(-4,959)\end{array}$ & $\begin{array}{l}-0,010^{* * * *} \\
(-4,344)\end{array}$ \\
\hline Dummies $\mathrm{t}$ & aporais & Sim & & & Sim & & \\
\hline PseudoR ${ }^{2}$ & & & 0,0647 & 0,0526 & 0,0259 & 0,0319 & 0,0943 \\
\hline $\begin{array}{l}R^{2} \\
\left(R^{2} \text { ajust.) }\right.\end{array}$ & & $\begin{array}{c}0,0504 \\
(0,0141)\end{array}$ & & & & & \\
\hline Teste $F$ & & 0,953 & & & & & \\
\hline \multicolumn{2}{|c|}{ Heterocedasticidade } & $\begin{array}{c}6,528^{* * *} \\
285,428^{* * *}\end{array}$ & $\begin{array}{l}\text { (Pesaran-7 } \\
\text { (Breusch-I }\end{array}$ & an-MQO) & & & \\
\hline Normalida & & $158,424^{* * *}$ & \multicolumn{5}{|c|}{ (Doornik-Hansen) } \\
\hline
\end{tabular}

*, ** e $* * *$ indicam a significância estatística bicaudal a $10 \%, 5 \%$; e $1 \%$, respectivamente.

Fonte: dados da pesquisa 
Tabela 30 - Resultados para a Decisão 3 - Equação (33): variável dependente DCTA

\begin{tabular}{|c|c|c|c|c|c|c|c|}
\hline \multirow{3}{*}{ Obs $=270$} & \multirow{3}{*}{$\begin{array}{c}\text { Sinal } \\
\text { Previsto }\end{array}$} & \multicolumn{6}{|c|}{$\begin{array}{l}\text { Coeficientes } \\
\text { (estatísticas } t)\end{array}$} \\
\hline & & \multirow{2}{*}{$\begin{array}{c}\text { Painel com } \\
\text { Efeitos } \\
\text { Aleatórios }\end{array}$} & \multicolumn{5}{|c|}{$\begin{array}{l}\text { Regressão Quantílica } \\
\text { (Erros padrão robustos) }\end{array}$} \\
\hline & & & Q05 & Q25 & Q50 & Q75 & Q95 \\
\hline Const & $?$ & $\begin{array}{c}0,093 \\
(1,645)\end{array}$ & $\begin{array}{c}-0,008 \\
(-1,507)\end{array}$ & $\begin{array}{c}0,018 \\
(0,898)\end{array}$ & $\begin{array}{c}0,012 \\
(0,308)\end{array}$ & $\begin{array}{c}0,071 \\
(1,298)\end{array}$ & $\begin{array}{l}0,371^{* * *} \\
(3,292)\end{array}$ \\
\hline Prob & - & $\begin{array}{c}-0,023 \\
(-0,083)\end{array}$ & $\begin{array}{c}0,008 \\
(0,264)\end{array}$ & $\begin{array}{c}0,134 \\
(1,265)\end{array}$ & $\begin{array}{c}-0,023 \\
(-0,118)\end{array}$ & $\begin{array}{l}0,522^{*} \\
(1,827)\end{array}$ & $\begin{array}{c}0,923 \\
(1,579)\end{array}$ \\
\hline Prob_Dif & - & $\begin{array}{l}-0,061^{*} \\
(-1,805)\end{array}$ & $\begin{array}{c}0,003 \\
(0,982)\end{array}$ & $\begin{array}{c}-0,012 \\
(-0,946)\end{array}$ & $\begin{array}{l}-0,046^{*} \\
(-1,949)\end{array}$ & $\begin{array}{l}-0,074^{* *} \\
(-2,179)\end{array}$ & $\begin{array}{l}-0,181^{\text {*** }} \\
(-2,589)\end{array}$ \\
\hline$E S C$ & + & $\begin{array}{l}0,0003 \\
(0,051)\end{array}$ & $\begin{array}{l}0,0006 \\
(0,602)\end{array}$ & $\begin{array}{c}-0,002 \\
(-0,690)\end{array}$ & $\begin{array}{c}-0,007 \\
(-1,027)\end{array}$ & $\begin{array}{l}-0,017^{*} \\
(-1,775)\end{array}$ & $\begin{array}{l}0,041^{* *} \\
(2,101)\end{array}$ \\
\hline Inv_Inst & - & $\begin{array}{c}-0,021 \\
(-0,798)\end{array}$ & $\begin{array}{l}0,006^{* *} \\
(1,969)\end{array}$ & $\begin{array}{c}0,016 \\
(1,492) \\
\end{array}$ & $\begin{array}{c}0,007 \\
(0,354) \\
\end{array}$ & $\begin{array}{c}-0,020 \\
(-0,698))\end{array}$ & $\begin{array}{c}0,011 \\
(0,189) \\
\end{array}$ \\
\hline Gov & - & $\begin{array}{c}0,008 \\
(0,692) \\
\end{array}$ & $\begin{array}{l}0,002^{*} \\
(1,923) \\
\end{array}$ & $\begin{array}{c}0,005 \\
(1,327) \\
\end{array}$ & $\begin{array}{c}0,011 \\
(1,559) \\
\end{array}$ & $\begin{array}{c}0,036^{* * *} \\
(3,551)\end{array}$ & $\begin{array}{l}-0,045^{* *} \\
(-2,167)\end{array}$ \\
\hline Rem & + & $\begin{array}{c}0,010 \\
(1,029)\end{array}$ & $\begin{array}{l}-0,0003 \\
(-0,295)\end{array}$ & $\begin{array}{c}0,002 \\
(0,602)\end{array}$ & $\begin{array}{l}0,0009 \\
(0,128)\end{array}$ & $\begin{array}{c}-0,004 \\
(-0,360) \\
\end{array}$ & $\begin{array}{l}0,058^{* * *} \\
(2,634)\end{array}$ \\
\hline Big4 & - & $\begin{array}{c}-0,011 \\
(-1,379) \\
\end{array}$ & $\begin{array}{l}-0,0009 \\
(-1,145) \\
\end{array}$ & $\begin{array}{l}0,0004 \\
(0,138) \\
\end{array}$ & $\begin{array}{c}-0,005 \\
(-0,942)\end{array}$ & $\begin{array}{l}-0,0009 \\
(-0,118)\end{array}$ & $\begin{array}{c}-0,014 \\
(-0,895)\end{array}$ \\
\hline Ativo & + & $\begin{array}{c}-0,002 \\
(-0,716) \\
\end{array}$ & $\begin{array}{l}0,0004 \\
(1,425) \\
\end{array}$ & $\begin{array}{l}-0,0006 \\
(-0,635) \\
\end{array}$ & $\begin{array}{c}0,001 \\
(0,817) \\
\end{array}$ & $\begin{array}{l}-0,0007 \\
(-0,260) \\
\end{array}$ & $\begin{array}{l}-0,012^{* *} \\
(-2,282) \\
\end{array}$ \\
\hline \multicolumn{2}{|c|}{ Dummies temporais } & Não & & & Sim & & \\
\hline \multicolumn{2}{|l|}{ PseudoR ${ }^{2}$} & & 0,0255 & 0,0264 & 0,0311 & 0,1066 & 0,1679 \\
\hline \multicolumn{2}{|l|}{$\begin{array}{l}R^{2} \\
\left(R^{2} \text { ajust. }\right)\end{array}$} & $\begin{array}{c}0,0571 \\
(0,0244)\end{array}$ & & & & & \\
\hline \multicolumn{2}{|c|}{ Teste de Chow } & $47,458^{* * *}$ & & & & & \\
\hline \multicolumn{2}{|l|}{$\begin{array}{l}\text { Teste } \\
\text { Pagan }\end{array}$} & $11,229^{* * *}$ & & & & & \\
\hline \multicolumn{2}{|c|}{ Teste de Hausman } & 9,001 & \multicolumn{5}{|c|}{$p$-valor $(0,5320)$} \\
\hline \multicolumn{2}{|c|}{$\begin{array}{l}\text { Heterocedasticidade } \\
\text { (MQO) }\end{array}$} & $150,497^{* * *}$ & \multicolumn{2}{|c|}{ (Breusch-Pagan) } & & & \\
\hline
\end{tabular}

$*, * * \mathrm{e}^{* * *}$ indicam a significância estatística bicaudal a $10 \%, 5 \%$; e 1\%, respectivamente.

Fonte: dados da pesquisa 
Tabela 31 - Resultados para a Decisão 4 - Equação (33): variável dependente DCTA

\begin{tabular}{|c|c|c|c|c|c|c|c|}
\hline \multirow{3}{*}{$\mathrm{Obs}=270$} & \multirow{3}{*}{$\begin{array}{l}\text { Sinal } \\
\text { Previsto }\end{array}$} & \multicolumn{6}{|c|}{$\begin{array}{l}\text { Coeficientes } \\
\text { (estatísticas } t)\end{array}$} \\
\hline & & \multirow{2}{*}{$\begin{array}{l}\text { Painel com } \\
\text { Efeitos } \\
\text { Aleatórios }\end{array}$} & \multicolumn{5}{|c|}{$\begin{array}{l}\text { Regressão Quantílica } \\
\text { (Erros padrão robustos) }\end{array}$} \\
\hline & & & Q05 & Q25 & Q50 & Q75 & Q95 \\
\hline Const & ? & $\begin{array}{l}0,094^{* *} \\
(2,176)\end{array}$ & $\begin{array}{c}0,002 \\
(0,627)\end{array}$ & $\begin{array}{c}0,039 \\
(1,123)\end{array}$ & $\begin{array}{l}0,122^{* * *} \\
(3,520)\end{array}$ & $\begin{array}{c}0,097 \\
(1,435)\end{array}$ & $\begin{array}{c}-0,016 \\
(-0,344) \\
\end{array}$ \\
\hline$p$ & - & $\begin{array}{l}0,538^{* *} \\
(2,263)\end{array}$ & $\begin{array}{l}0,108^{* *} \\
(2,067)\end{array}$ & $\begin{array}{c}0,226 \\
(1,123) \\
\end{array}$ & $\begin{array}{l}0,523^{* *} \\
(2,103) \\
\end{array}$ & $\begin{array}{l}0,807^{* *} \\
(2,677) \\
\end{array}$ & $\begin{array}{l}1,917^{* * *} \\
(19,813) \\
\end{array}$ \\
\hline pDif & - & $\begin{array}{c}0,025 \\
(0,953) \\
\end{array}$ & $\begin{array}{l}0,018^{* * * *} \\
(3,415) \\
\end{array}$ & $\begin{array}{c}0,043^{* * *} \\
(3,006) \\
\end{array}$ & $\begin{array}{c}0,051^{* * *} \\
(2,935) \\
\end{array}$ & $\begin{array}{c}0,032 \\
(0,940) \\
\end{array}$ & $\begin{array}{c}-0,002 \\
(-0,157) \\
\end{array}$ \\
\hline$E S C$ & + & $\begin{array}{l}0,008^{*} \\
(1,804)\end{array}$ & $\begin{array}{c}-0,001 \\
(-0,409)\end{array}$ & $\begin{array}{c}0,002 \\
(0,184)\end{array}$ & $\begin{array}{l}0,006^{* *} \\
(2,413)\end{array}$ & $\begin{array}{c}0,006 \\
(0,358)\end{array}$ & $\begin{array}{c}0,008 \\
(1,267)\end{array}$ \\
\hline Inv_Inst & - & $\begin{array}{c}-0,017 \\
(-0,825) \\
\end{array}$ & $\begin{array}{c}-0,002 \\
(-0,038)\end{array}$ & $\begin{array}{l}-0,011 \\
(-0,193)\end{array}$ & $\begin{array}{l}-0,035 \\
(-0,783)\end{array}$ & $\begin{array}{l}-0,006 \\
(-0,186)\end{array}$ & $\begin{array}{c}-0,006 \\
(-0,359)\end{array}$ \\
\hline Gov & - & $\begin{array}{l}0,021^{* *} \\
(2,060) \\
\end{array}$ & $\begin{array}{c}0,003 \\
(1,167) \\
\end{array}$ & $\begin{array}{c}0,007 \\
(0,956)\end{array}$ & $\begin{array}{c}0,012 \\
(1,132)\end{array}$ & $\begin{array}{c}0,035^{* * *} \\
(6,043)\end{array}$ & $\begin{array}{c}0,046 \\
(1,583) \\
\end{array}$ \\
\hline Rem & + & $\begin{array}{l}-0,006 \\
(-0,654)\end{array}$ & $\begin{array}{c}-0,001 \\
(-0,642)\end{array}$ & $\begin{array}{l}-0,005 \\
(-0,748)\end{array}$ & $\begin{array}{c}0,001 \\
(0,178)\end{array}$ & $\begin{array}{l}-0,003 \\
(-0,476)\end{array}$ & $\begin{array}{c}-0,034 \\
(-1,367)\end{array}$ \\
\hline Big4 & - & $\begin{array}{c}0,001 \\
(0,139)\end{array}$ & $\begin{array}{l}0,004^{* *} \\
(2,216)\end{array}$ & $\begin{array}{c}0,006^{*} \\
(1,778)\end{array}$ & $\begin{array}{c}0,005 \\
(1,514)\end{array}$ & $\begin{array}{l}-0,003 \\
(-0,437)\end{array}$ & $\begin{array}{c}-0,021 \\
(-1,572)\end{array}$ \\
\hline Ativo & + & $\begin{array}{l}-0,004^{* *} \\
(-2,094)\end{array}$ & $\begin{array}{l}-0,0005^{* *} \\
(-2,072) \\
\end{array}$ & $\begin{array}{c}-0,002 \\
(-1,432)\end{array}$ & $\begin{array}{l}-0,007^{* * * *} \\
(-3,957) \\
\end{array}$ & $\begin{array}{l}-0,005 \\
(-1,419) \\
\end{array}$ & $\begin{array}{l}0,0007 \\
(0,309) \\
\end{array}$ \\
\hline \multicolumn{2}{|c|}{ Dummies temporais } & Não & \multicolumn{5}{|c|}{$\mathrm{Sim}$} \\
\hline \multicolumn{2}{|l|}{ PseudoR ${ }^{2}$} & & 0,0739 & 0,0875 & 0,1113 & 0,1574 & 0,2702 \\
\hline \multicolumn{2}{|l|}{$\begin{array}{l}R^{2} \\
\left(R^{2} \text { ajust. }\right)\end{array}$} & $\begin{array}{c}0,1139 \\
(0,0464)\end{array}$ & & & & & \\
\hline \multicolumn{2}{|c|}{ Teste de Chow } & $357,588^{* * *}$ & & & & & \\
\hline $\begin{array}{l}\text { Teste de } \\
\text { Pagan }\end{array}$ & Breusch- & $3,382^{*}$ & & & & & \\
\hline Teste de $H a$ & usman & 7,510 & $p$-valor $(0$, & & & & \\
\hline $\begin{array}{l}\text { Heterocedas } \\
\text { (MQO) }\end{array}$ & ticidade & $28,279^{* * *}$ & (Breusch-I & an) & & & \\
\hline
\end{tabular}

Fonte: dados da pesquisa 


\section{APÊNDICE E: RESULTADOS DAS ESTIMAÇÕES DO MODELO (33) - Variável}

\section{Dependente - DCT}

$$
\begin{aligned}
\text { DCT }_{i t}=\beta_{0}+ & \beta_{1} \text { Prob }_{i t} \\
& +\beta_{2} \text { Prob_Dif }_{i t}+\beta_{3} \text { ESC }_{i t} \\
& +\lambda_{1} \text { Inv }_{-} \text {Inst }_{i t}+\lambda_{2} \text { Gov }_{i t}+\lambda_{3} \text { Rem }_{i t}+\lambda_{4} \text { Big }_{i t} \\
& +\delta_{1} \text { Ativo }_{i t}+\delta_{2} d 2011+\delta_{3} d 2012+\delta_{4} d 2013+v_{i t}
\end{aligned}
$$

\begin{tabular}{|c|c|c|c|c|c|c|c|}
\hline \multirow{3}{*}{$\mathrm{Obs}=846$} & \multirow{3}{*}{$\begin{array}{c}\text { Sinal } \\
\text { Previsto }\end{array}$} & \multicolumn{6}{|c|}{$\begin{array}{l}\text { Coeficientes } \\
\text { (estatísticas } t \text { ) }\end{array}$} \\
\hline & & \multirow[t]{2}{*}{ MQO } & \multicolumn{5}{|c|}{$\begin{array}{l}\text { Regressão Quantílica } \\
\text { (Erros padrão robustos) }\end{array}$} \\
\hline & & & Q05 & Q25 & Q50 & Q75 & Q95 \\
\hline Const & $?$ & $\begin{array}{c}0,042 \\
(0,841)\end{array}$ & $\begin{array}{c}0,018 \\
(1,033)\end{array}$ & $\begin{array}{c}0,005 \\
(0,735)\end{array}$ & $\begin{array}{c}-0,007 \\
(-0,582)\end{array}$ & $\begin{array}{c}-0,016 \\
(-0,352)\end{array}$ & $\begin{array}{l}0,142^{*} \\
(1,747)\end{array}$ \\
\hline Prob & - & $\begin{array}{c}-0,315 \\
(-1,484)\end{array}$ & $\begin{array}{l}-0,337^{* * *} \\
(-3,453)\end{array}$ & $\begin{array}{c}-0,019 \\
(-0,484)\end{array}$ & $\begin{array}{c}-0,028 \\
(-0,415)\end{array}$ & $\begin{array}{c}0,127 \\
(0,500)\end{array}$ & $\begin{array}{l}1,231^{\text {*** }} \\
(2,704)\end{array}$ \\
\hline Prob_Dif & - & $\begin{array}{l}-0,135^{* * *} \\
(-5,615)\end{array}$ & $\begin{array}{c}0,016 \\
(1,443)\end{array}$ & $\begin{array}{l}-0,010^{* *} \\
(-2,351)\end{array}$ & $\begin{array}{c}-0,012 \\
(-1,587)\end{array}$ & $\begin{array}{l}-0,152^{* * *} \\
(-5,261)\end{array}$ & $\begin{array}{l}-0,517^{* * *} \\
(-9,961)\end{array}$ \\
\hline ESC & + & $\begin{array}{l}0,020^{* *} \\
(2,565)\end{array}$ & $\begin{array}{l}0,007^{* *} \\
(2,499)\end{array}$ & $\begin{array}{c}0,001 \\
(0,996)\end{array}$ & $\begin{array}{c}0,003 \\
(1,396)\end{array}$ & $\begin{array}{c}0,022^{* * *} \\
(2,906)\end{array}$ & $\begin{array}{l}0,038^{* * *} \\
(2,760)\end{array}$ \\
\hline Inv_Inst & - & $\begin{array}{l}0,074^{* * *} \\
(3,023)\end{array}$ & $\begin{array}{l}0,024^{* *} \\
(2,365)\end{array}$ & $\begin{array}{l}0,045^{* * *} \\
(10,993)\end{array}$ & $\begin{array}{l}0,051^{* * *} \\
(7,119)\end{array}$ & $\begin{array}{l}0,124^{* * *} \\
(4,644)\end{array}$ & $\begin{array}{c}0,044 \\
(0,929)\end{array}$ \\
\hline Gov & - & $\begin{array}{l}0,028^{* * *} \\
(4,134)\end{array}$ & $\begin{array}{l}0,013^{* * *} \\
(3,777)\end{array}$ & $\begin{array}{l}0,017^{* * *} \\
(12,013)\end{array}$ & $\begin{array}{l}0,018^{* * *} \\
(7,441)\end{array}$ & $\begin{array}{l}0,025^{\text {**** }} \\
(2,699)\end{array}$ & $\begin{array}{l}0,035^{\text {** }} \\
(2,104)\end{array}$ \\
\hline Rem & + & $\begin{array}{c}0,010 \\
(1,541)\end{array}$ & $\begin{array}{l}0,020^{* * * *} \\
(5,933)\end{array}$ & $\begin{array}{l}0,003^{* *} \\
(2,256)\end{array}$ & $\begin{array}{c}0,016^{* * *} \\
(6,973)\end{array}$ & $\begin{array}{c}0,010 \\
(1,152)\end{array}$ & $\begin{array}{c}0,000 \\
(0,020)\end{array}$ \\
\hline Big4 & - & $\begin{array}{c}0,004 \\
(0,689)\end{array}$ & $\begin{array}{l}-0,015^{\text {*** }} \\
(-5,940)\end{array}$ & $\begin{array}{c}0,001 \\
(1,408)\end{array}$ & $\begin{array}{c}0,008^{* * *} \\
(4,566)\end{array}$ & $\begin{array}{c}0,009 \\
(1,459)\end{array}$ & $\begin{array}{c}-0,015 \\
(-1,270)\end{array}$ \\
\hline Ativo & + & $\begin{array}{c}0,001 \\
(0,515)\end{array}$ & $\begin{array}{l}-0,002^{* *} \\
(-2,136)\end{array}$ & $\begin{array}{c}-0,000 \\
(-0,647)\end{array}$ & $\begin{array}{c}0,001 \\
(1,238)\end{array}$ & $\begin{array}{c}0,004^{*} \\
(1,799)\end{array}$ & $\begin{array}{c}0,002 \\
(0,649)\end{array}$ \\
\hline \multicolumn{2}{|c|}{ Dummies temporais } & $\operatorname{Sim}$ & \multicolumn{5}{|c|}{ Sim } \\
\hline \multicolumn{2}{|l|}{ PseudoR $^{2}$} & & 0,0441 & 0,0316 & 0,1153 & 0,1253 & 0,2030 \\
\hline \multicolumn{2}{|l|}{$\begin{array}{l}R^{2} \\
\left(R^{2} \text { ajust. }\right)\end{array}$} & $\begin{array}{c}0,1309 \\
(0,1195)\end{array}$ & & & & & \\
\hline \multicolumn{2}{|l|}{ Teste $F$} & $12,988^{* * *}$ & & & & & \\
\hline \multicolumn{2}{|c|}{ Heterocedasticidade } & $38,430^{* * *}$ & \multicolumn{2}{|c|}{ (Breusch-Pagan) } & & & \\
\hline \multicolumn{2}{|c|}{ Normalidade } & $524,23^{* * *}$ & \multicolumn{2}{|c|}{ (Doornik-Hansen) } & & & \\
\hline \multicolumn{2}{|c|}{ Multicolinariedade } & VIF's $<2,5$ & & & & & \\
\hline
\end{tabular}

Tabela 32 - Resultados para a Amostra Total - Equação (33): variável dependente DCT

$*, * * \mathrm{e} * * *$ indicam a significância estatística bicaudal a $10 \%, 5 \%$; e $1 \%$, respectivamente.

Fonte: dados da pesquisa 
Tabela 33 - Resultados para a Decisão 1 - Equação (33): variável dependente DCT

\begin{tabular}{|c|c|c|c|c|c|c|c|}
\hline \multirow{3}{*}{$\mathrm{Obs}=558$} & \multirow{3}{*}{$\begin{array}{c}\text { Sinal } \\
\text { Previsto }\end{array}$} & \multicolumn{6}{|c|}{ Coeficientes } \\
\hline & & \multirow[t]{2}{*}{$\begin{array}{l}\text { MQ2E } \\
\text { (estat. } z \text { ) }\end{array}$} & \multicolumn{5}{|c|}{$\begin{array}{c}\text { Regressão Quantílica } \\
\text { (estatísticas } t \text { ) } \\
\text { (Erros padrão robustos) }\end{array}$} \\
\hline & & & Q05 & $\mathrm{Q} 25$ & Q50 & Q75 & Q95 \\
\hline Const & ? & $\begin{array}{c}-0,250 \\
(-0,744)\end{array}$ & $\begin{array}{c}-0,013 \\
(-0,982)\end{array}$ & $\begin{array}{l}-0,040^{*} \\
(-1,776)\end{array}$ & $\begin{array}{c}-0,011 \\
(-0,485)\end{array}$ & $\begin{array}{c}0,053 \\
(1,030)\end{array}$ & $\begin{array}{l}0,231^{* * *} \\
(3,571)\end{array}$ \\
\hline Prob & - & $\begin{array}{l}-4,700 \\
(-1,110)\end{array}$ & $\begin{array}{c}-0,019 \\
(-0,257)\end{array}$ & $\begin{array}{c}-0,016 \\
(-0,124)\end{array}$ & $\begin{array}{l}0,262^{* *} \\
(2,051)\end{array}$ & $\begin{array}{c}0,175 \\
(0,592)\end{array}$ & $\begin{array}{c}1,056^{* * *} \\
(2,846)\end{array}$ \\
\hline Prob_Dif & - & $\begin{array}{l}-0,151^{*} \\
(-1,663)\end{array}$ & $\begin{array}{c}-0,003 \\
(-0,368)\end{array}$ & $\begin{array}{c}-0,044^{* * *} \\
(-3,052)\end{array}$ & $\begin{array}{c}-0,130^{* * * *} \\
(-9,107)\end{array}$ & $\begin{array}{l}-0,348^{* * *} \\
(-10,526)\end{array}$ & $\begin{array}{l}-0,552^{* * *} \\
(-13,292)\end{array}$ \\
\hline ESC & + & $\begin{array}{c}0,751 \\
(1,180)\end{array}$ & $\begin{array}{c}0,005 \\
(1,360)\end{array}$ & $\begin{array}{l}0,013^{*} \\
(1,859)\end{array}$ & $\begin{array}{c}0,037^{* * * *} \\
(5,396)\end{array}$ & $\begin{array}{c}0,050^{* * * *} \\
(3,196)\end{array}$ & $\begin{array}{c}0,178^{* * * *} \\
(8,924)\end{array}$ \\
\hline Inv_Inst & - & $\begin{array}{c}0,009 \\
(0,185)\end{array}$ & $\begin{array}{c}0,008 \\
(1,210)\end{array}$ & $\begin{array}{c}0,034^{* * * *} \\
(2,975)\end{array}$ & $\begin{array}{c}0,066^{* * * *} \\
(5,811)\end{array}$ & $\begin{array}{c}0,089^{* * * *} \\
(3,413)\end{array}$ & $\begin{array}{c}0,044 \\
(1,349)\end{array}$ \\
\hline Gov & - & $\begin{array}{c}0,015 \\
(0,796) \\
\end{array}$ & $\begin{array}{l}0,008^{* * *} \\
(3,588)\end{array}$ & $\begin{array}{l}0,010^{* *} \\
(2,499)\end{array}$ & $\begin{array}{c}0,017^{* * * *} \\
(4,113) \\
\end{array}$ & $\begin{array}{l}0,018^{*} \\
(1,885) \\
\end{array}$ & $\begin{array}{l}0,023^{*} \\
(1,925) \\
\end{array}$ \\
\hline Rem & + & $\begin{array}{c}-0,005 \\
(-0,234)\end{array}$ & $\begin{array}{c}0,000 \\
(0,187)\end{array}$ & $\begin{array}{c}0,005 \\
(1,223)\end{array}$ & $\begin{array}{l}-0,003 \\
(-0,676)\end{array}$ & $\begin{array}{c}-0,009 \\
(-0,964)\end{array}$ & $\begin{array}{c}0,005 \\
(0,449)\end{array}$ \\
\hline Big4 & - & $\begin{array}{c}-0,000 \\
(-0,325) \\
\end{array}$ & $\begin{array}{c}0,002 \\
(0,995) \\
\end{array}$ & $\begin{array}{l}0,008^{* * *} \\
(2,649) \\
\end{array}$ & $\begin{array}{c}0,009^{* * * *} \\
(2,953)\end{array}$ & $\begin{array}{c}-0,003 \\
(-0,439) \\
\end{array}$ & $\begin{array}{c}-0,023^{* * *} \\
(-2,514) \\
\end{array}$ \\
\hline Ativo & + & $\begin{array}{c}0,020 \\
(1,044) \\
\end{array}$ & $\begin{array}{c}0,000 \\
(1,023) \\
\end{array}$ & $\begin{array}{l}0,003^{* *} \\
(2,490)\end{array}$ & $\begin{array}{l}0,003^{* * *} \\
(2,426)\end{array}$ & $\begin{array}{l}0,005^{*} \\
(1,887)\end{array}$ & $\begin{array}{c}-0,001 \\
(-0,270) \\
\end{array}$ \\
\hline \multicolumn{2}{|c|}{ Dummies temporais } & Sim & \multicolumn{5}{|c|}{ Sim } \\
\hline \multicolumn{2}{|l|}{ PseudoR ${ }^{2}$} & & 0,0464 & 0,0693 & 0,0983 & 0,1586 & 0,2544 \\
\hline \multicolumn{2}{|l|}{$\begin{array}{l}R^{2} \\
\left(R^{2} \text { ajust. }\right)\end{array}$} & $\begin{array}{c}0,0262 \\
(0,0066)\end{array}$ & & & & & \\
\hline \multicolumn{2}{|l|}{ Teste $F$} & $3,533^{* * * *}$ & & & & & \\
\hline \multicolumn{2}{|c|}{ Exogeneidade } & $15,072^{* * *}$ & \multicolumn{5}{|l|}{ (Hausman) } \\
\hline \multicolumn{2}{|c|}{ Valid. dos Instrum. } & 0,121 & (Sargan) & & & & \\
\hline \multirow{2}{*}{\multicolumn{2}{|c|}{ Heterocedasticidade }} & 0,102 & (Pesaran- $T$ & & & & \\
\hline & & $232,980^{* * *}$ & (Breusch-P & an $M Q O)$ & & & \\
\hline \multicolumn{2}{|c|}{ Normalidade } & $230,262^{* * *}$ & (Doornik-H & sen) & & & \\
\hline
\end{tabular}

Os instrumentos são fracos - estat. F primeira fase $\rightarrow 0,951912$

*, ** e *** indicam a significância estatística bicaudal a $10 \%, 5 \%$; e $1 \%$, respectivamente.

Fonte: dados da pesquisa 
Tabela 34 - Resultados para a Decisão 2 - Equação (33): variável dependente DCT

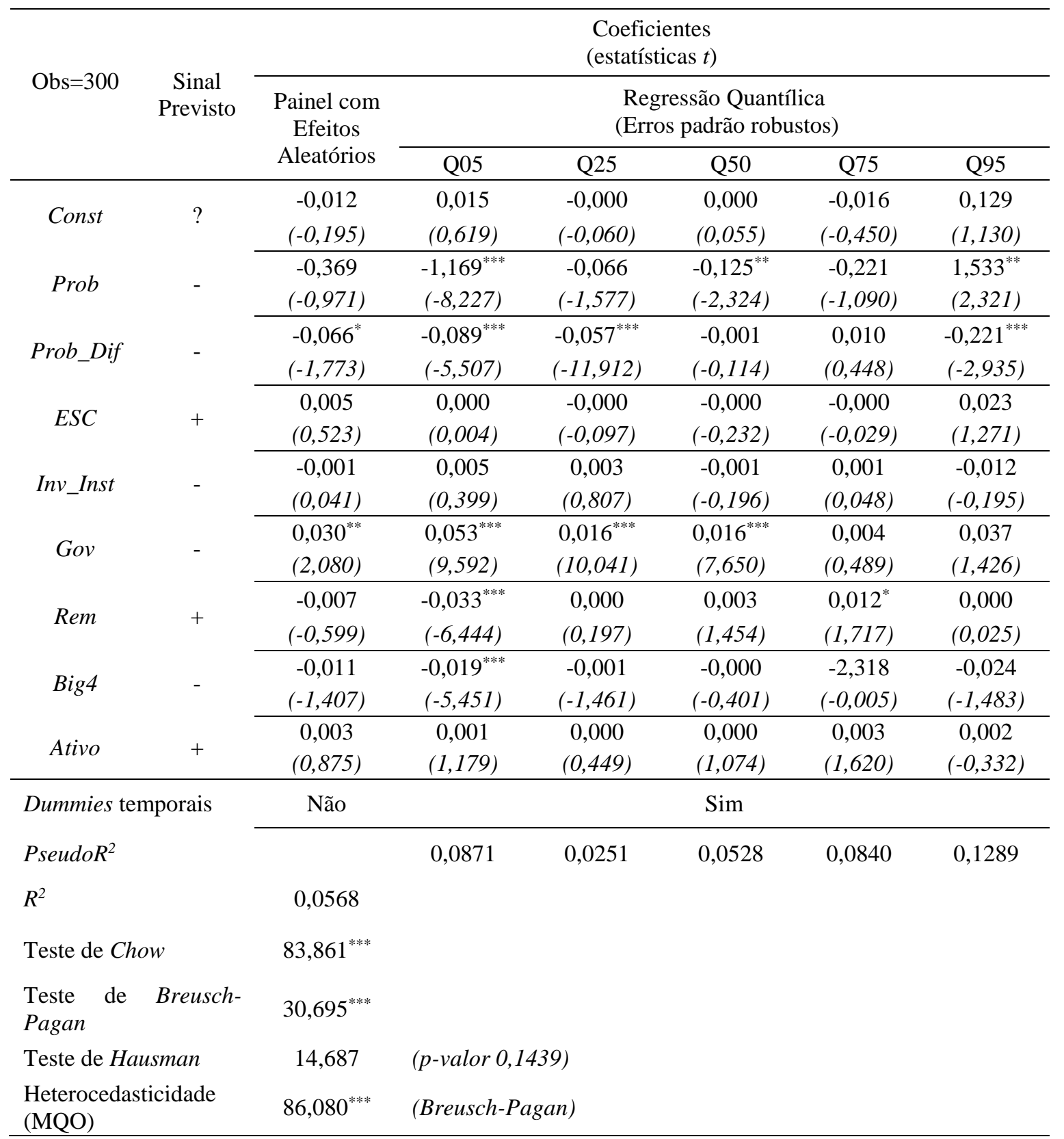

*, ** e *** indicam a significância estatística bicaudal a 10\%,5\%; e $1 \%$, respectivamente.

Fonte: dados da pesquisa 
Tabela 35 - Resultados para a Decisão 3 - Equação (33): variável dependente $D C T$

\begin{tabular}{|c|c|c|c|c|c|c|c|}
\hline \multirow{3}{*}{ Obs $=410$} & \multirow{3}{*}{$\begin{array}{c}\text { Sinal } \\
\text { Previsto }\end{array}$} & \multicolumn{6}{|c|}{$\begin{array}{l}\text { Coeficientes } \\
\text { (estatísticas } t)\end{array}$} \\
\hline & & \multirow{2}{*}{$\begin{array}{l}\text { Painel com } \\
\text { Efeitos } \\
\text { Aleatórios }\end{array}$} & \multicolumn{5}{|c|}{$\begin{array}{l}\text { Regressão Quantílica } \\
\text { (Erros padrão robustos) }\end{array}$} \\
\hline & & & Q05 & Q25 & Q50 & Q75 & Q95 \\
\hline Const & $?$ & $\begin{array}{l}0,132^{* *} \\
(2,131)\end{array}$ & $\begin{array}{l}-0,045^{* *} \\
(-2,179)\end{array}$ & $\begin{array}{l}-0,070^{* * * *} \\
(-3,826)\end{array}$ & $\begin{array}{l}-0,042 \\
(-1,283\end{array}$ & $\begin{array}{c}0,006 \\
(0,128)\end{array}$ & $\begin{array}{l}0,392^{* * *} \\
(4,174)\end{array}$ \\
\hline Prob & - & $\begin{array}{l}0,840^{* * *} \\
(2,028)\end{array}$ & $\begin{array}{c}0,056 \\
(0,485)\end{array}$ & $\begin{array}{c}0,026 \\
(0,256) \\
\end{array}$ & $\begin{array}{l}0,413^{* *} \\
(2,218) \\
\end{array}$ & $\begin{array}{c}0,175 \\
(0,612) \\
\end{array}$ & $\begin{array}{c}0,406 \\
(0,770)\end{array}$ \\
\hline Prob_Dif & - & $\begin{array}{l}-0,069^{*} \\
(-1,912)\end{array}$ & $\begin{array}{l}-0,018 \\
(-1,346)\end{array}$ & $\begin{array}{l}-0,047^{* * * *} \\
(-3,983)\end{array}$ & $\begin{array}{l}-0,185^{* * *} \\
(-8,785)\end{array}$ & $\begin{array}{l}-0,316^{* * *} \\
(-9,728)\end{array}$ & $\begin{array}{c}-0,650 \\
(-10,858)\end{array}$ \\
\hline$E S C$ & + & $\begin{array}{c}0,069 \\
(1,407) \\
\end{array}$ & $\begin{array}{c}0,006 \\
(1,001)\end{array}$ & $\begin{array}{l}0,012^{* *} \\
(2,084) \\
\end{array}$ & $\begin{array}{c}0,004 \\
(0,411) \\
\end{array}$ & $\begin{array}{c}0,021 \\
(1,372) \\
\end{array}$ & $\begin{array}{c}0,029 \\
(1,001)\end{array}$ \\
\hline Inv_Inst & - & $\begin{array}{c}-0,011 \\
(-0,439)\end{array}$ & $\begin{array}{l}0,060^{* * *} \\
(5,664)\end{array}$ & $\begin{array}{l}0,071^{* * *} \\
(7,448)\end{array}$ & $\begin{array}{l}0,107^{* * *} \\
(6,293)\end{array}$ & $\begin{array}{l}0,100^{* * *} \\
(3,811)\end{array}$ & $\begin{array}{c}0,029 \\
(0,608)\end{array}$ \\
\hline Gov & - & $\begin{array}{c}0,012 \\
(0,941)\end{array}$ & $\begin{array}{l}0,011^{* * *} \\
(3,045)\end{array}$ & $\begin{array}{l}0,008^{* *} \\
(2,658)\end{array}$ & $\begin{array}{l}0,019^{* * *} \\
(3,284)\end{array}$ & $\begin{array}{l}0,026^{* * *} \\
(2,945) \\
\end{array}$ & $\begin{array}{c}0,014 \\
(0,829)\end{array}$ \\
\hline Rem & + & $\begin{array}{c}0,013 \\
(1,041)\end{array}$ & $\begin{array}{c}-0,005 \\
(-1,381)\end{array}$ & $\begin{array}{c}0,003 \\
(0,828)\end{array}$ & $\begin{array}{l}-0,006 \\
(-1,048)\end{array}$ & $\begin{array}{l}-0,008 \\
(-0,850)\end{array}$ & $\begin{array}{c}0,011 \\
(0,692)\end{array}$ \\
\hline Big4 & - & $\begin{array}{c}-0,005 \\
(-0,649)\end{array}$ & $\begin{array}{l}0,006^{* *} \\
(2,229)\end{array}$ & $\begin{array}{l}0,011^{* * * *} \\
(4,210)\end{array}$ & $\begin{array}{c}0,008^{*} \\
(1,682)\end{array}$ & $\begin{array}{l}-0,001 \\
(-0,116)\end{array}$ & $\begin{array}{l}-0,024^{*} \\
(1,819)\end{array}$ \\
\hline Ativo & + & $\begin{array}{c}-0,005 \\
(-1,630) \\
\end{array}$ & $\begin{array}{l}0,002^{* *} \\
(2,078)\end{array}$ & $\begin{array}{l}0,004^{* * *} \\
(4,634)\end{array}$ & $\begin{array}{l}0,005^{* * *} \\
(3,283) \\
\end{array}$ & $\begin{array}{l}0,007^{* * *} \\
(2,729)\end{array}$ & $\begin{array}{c}0,004 \\
(-0,885)\end{array}$ \\
\hline \multicolumn{2}{|c|}{ Dummies temporais } & Não & \multicolumn{5}{|c|}{ Sim } \\
\hline \multicolumn{2}{|l|}{ PseudoR ${ }^{2}$} & & 0,0779 & 0,0892 & 0,1154 & 0,1748 & 0,2403 \\
\hline \multicolumn{2}{|l|}{$R^{2}$} & 0,1500 & & & & & \\
\hline \multicolumn{2}{|c|}{ Teste de Chow } & $31,207^{* * *}$ & & & & & \\
\hline $\begin{array}{l}\text { Teste de } \\
\text { Pagan }\end{array}$ & Breusch- & $14632^{* * *}$ & & & & & \\
\hline Teste de $H c$ & ısman & 14,630 & (p-valor 0 & & & & \\
\hline $\begin{array}{l}\text { Heteroceda } \\
\text { (MQO) }\end{array}$ & icidade & $139,950^{* * *}$ & (Breusch & & & & \\
\hline
\end{tabular}

*, ** e *** indicam a significância estatística bicaudal a 10\%,5\%; e 1\%, respectivamente.

Fonte: dados da pesquisa 
Tabela 36 - Resultados para a Decisão 4 - Equação (33): variável dependente $D C T$

\begin{tabular}{|c|c|c|c|c|c|c|c|}
\hline \multirow{3}{*}{ Obs $=148$} & \multirow{3}{*}{$\begin{array}{c}\text { Sinal } \\
\text { Previsto }\end{array}$} & \multicolumn{6}{|c|}{ Coeficientes } \\
\hline & & \multirow[t]{2}{*}{$\begin{array}{c}\text { MQ2E } \\
\text { (estat. z) }\end{array}$} & \multicolumn{5}{|c|}{$\begin{array}{c}\text { Regressão Quantílica } \\
\text { (estatísticas } t) \\
\text { (Erros padrão robustos) }\end{array}$} \\
\hline & & & Q05 & Q25 & Q50 & Q75 & Q95 \\
\hline Const & $?$ & $\begin{array}{l}0,215^{* *} \\
(2,192)\end{array}$ & $\begin{array}{c}-0,003 \\
(-0,172) \\
\end{array}$ & $\begin{array}{c}0,004^{*} \\
(1,744)\end{array}$ & $\begin{array}{c}0,048 \\
(1,323) \\
\end{array}$ & $\begin{array}{c}0,123 \\
(1,235) \\
\end{array}$ & $\begin{array}{c}0,560^{\text {*** }} \\
(19,666)\end{array}$ \\
\hline Prob & - & $\begin{array}{l}1,188^{* * *} \\
(2,301)\end{array}$ & $\begin{array}{c}0,050 \\
(0,447)\end{array}$ & $\begin{array}{c}0,078^{* * * *} \\
(4,788)\end{array}$ & $\begin{array}{c}-0,036 \\
(-0,157)\end{array}$ & $\begin{array}{c}0,617 \\
(0,977) \\
\end{array}$ & $\begin{array}{c}1,590^{* * *} \\
(8,804)\end{array}$ \\
\hline Prob_Dif & - & $\begin{array}{l}-0,138^{* *} \\
(-2,263)\end{array}$ & $\begin{array}{c}-0,015 \\
(-1,294)\end{array}$ & $\begin{array}{l}-0,026^{* * * *} \\
(-16,046)\end{array}$ & $\begin{array}{c}-0,036 \\
(-1,570)\end{array}$ & $\begin{array}{l}-0,120^{*} \\
(-1,870)\end{array}$ & $\begin{array}{l}-0,276^{* * * *} \\
(-15,002)\end{array}$ \\
\hline$E S C$ & + & $\begin{array}{l}0,393^{* *} \\
(2,457)\end{array}$ & $\begin{array}{c}0,002 \\
(0,102)\end{array}$ & $\begin{array}{l}0,005^{* *} \\
(2,307)\end{array}$ & $\begin{array}{c}-0,029 \\
(-0,850)\end{array}$ & $\begin{array}{c}0,040 \\
(0,422)\end{array}$ & $\begin{array}{l}0,316^{* * *} \\
(11,736)\end{array}$ \\
\hline Inv_Inst & - & $\begin{array}{c}0,020 \\
(1,052)\end{array}$ & $\begin{array}{c}-0,010 \\
(-1,211)\end{array}$ & $\begin{array}{l}-0,022^{* * *} \\
(-19,224)\end{array}$ & $\begin{array}{c}-0,025 \\
(-1,526)\end{array}$ & $\begin{array}{c}0,016 \\
(0,355)\end{array}$ & $\begin{array}{c}-0,039^{* * *} \\
(-2,996)\end{array}$ \\
\hline Gov & - & $\begin{array}{c}0,000 \\
(1,052)\end{array}$ & $\begin{array}{c}0,001 \\
(0,278)\end{array}$ & $\begin{array}{l}0,008^{* * *} \\
(14,732)\end{array}$ & $\begin{array}{c}0,008 \\
(1,117)\end{array}$ & $\begin{array}{c}0,013 \\
(0,641)\end{array}$ & $\begin{array}{l}-0,012^{* *} \\
(-2,152)\end{array}$ \\
\hline Rem & + & $\begin{array}{c}0,019^{*} \\
(1,749)\end{array}$ & $\begin{array}{c}0,013^{* * *} \\
(3,705)\end{array}$ & $\begin{array}{l}0,011^{* * *} \\
(22,450)\end{array}$ & $\begin{array}{c}0,008 \\
(1,187)\end{array}$ & $\begin{array}{c}0,004 \\
(0,237)\end{array}$ & $\begin{array}{l}0,061^{* * *} \\
(10,965)\end{array}$ \\
\hline Big4 & - & $\begin{array}{c}-0,007 \\
(-0,961)\end{array}$ & $\begin{array}{c}0,000 \\
(0,233)\end{array}$ & $\begin{array}{l}0,005^{* * *} \\
(14,223)\end{array}$ & $\begin{array}{c}0,003 \\
(0,731)\end{array}$ & $\begin{array}{c}-0,007 \\
(-0,568)\end{array}$ & $\begin{array}{l}-0,010^{* *} \\
(-2,801)\end{array}$ \\
\hline Ativo & + & $\begin{array}{c}-0,008 \\
(-1,628) \\
\end{array}$ & $\begin{array}{c}0,000 \\
(0,240)\end{array}$ & $\begin{array}{c}0,000 * * \\
(2,522)\end{array}$ & $\begin{array}{c}-0,001 \\
(-0,439) \\
\end{array}$ & $\begin{array}{c}-0,002 \\
(-0,473)\end{array}$ & $\begin{array}{l}-0,020^{* * *} \\
(-13,471)\end{array}$ \\
\hline \multicolumn{2}{|c|}{ Dummies temporais } & Sim & \multicolumn{5}{|c|}{ Sim } \\
\hline \multicolumn{2}{|l|}{ PseudoR ${ }^{2}$} & & 0,1022 & 0,0875 & 0,0589 & 0,0901 & 0,3859 \\
\hline \multicolumn{2}{|l|}{$\begin{array}{l}R^{2} \\
\left(R^{2} \text { ajust. }\right)\end{array}$} & $\begin{array}{c}0,0714 \\
(-0,0036)\end{array}$ & & & & & \\
\hline \multicolumn{2}{|l|}{ Teste $F$} & 0,071 & & & & & \\
\hline \multicolumn{2}{|c|}{ Exogeneidade } & $6,767^{* * *}$ & (Hausman) & & & & \\
\hline \multicolumn{2}{|c|}{ Valid. dos Instrum. } & 2,000 & (Sargan) & & & & \\
\hline \multicolumn{2}{|c|}{ Heterocedasticidade } & $\begin{array}{l}6,951^{* * *} \\
54,240^{* * *}\end{array}$ & $\begin{array}{l}\text { (Pesaran-T } \\
(\text { Breusch }-P\end{array}$ & $\begin{array}{l}\text { lor) } \\
\text { an }-M Q O)\end{array}$ & & & \\
\hline \multicolumn{2}{|c|}{ Normalidade } & $20,079^{* * *}$ & (Doornik-H & isen) & & & \\
\hline
\end{tabular}

Instrumentos não são fracos - estat. F de primeira fase $\rightarrow 13,410$

$*, * * \mathrm{e} * * *$ indicam a significância estatística bicaudal a $10 \%, 5 \%$; e $1 \%$, respectivamente.

Fonte: dados da pesquisa 


\section{APÊNDICE F: RESULTADOS DAS ESTIMAÇÕES DO MODELO (35)}

$$
\begin{aligned}
& \text { DCTA }_{i t}= \beta_{0}+\beta_{1} \text { Prob }_{i t}+\beta_{2} \text { Prob_Dif }_{i t} \\
&+\lambda_{1} \text { GOVERN }_{i t}+\lambda_{2} \text { Prob }_{i t} \times \text { GOVERN }_{i t}+\lambda_{3} \text { Prob_Dif }_{i t} \times \text { GOVERN }_{i t} \\
& \quad+\delta_{1} \text { ESC }_{i t}+\delta_{2} \text { End }_{i t}+\delta_{3} \text { Ativo }_{i t}+\delta_{4} d 2011+\delta_{5} d 2012+\delta_{6} d 2013+\varepsilon_{i t}
\end{aligned}
$$

Tabela $37-$ Presença de Investidores Institucionais (GOVERN) - Equação (35)

Painel A - Amostra Total

\begin{tabular}{lccccc}
\hline \multirow{2}{*}{ Obs=846 } & \multicolumn{5}{c}{ Coeficientes } \\
\cline { 2 - 6 } & Q05 & Q25 & Q50 & Q75 & Q95 \\
\hline \multirow{2}{*}{ Prob } & $\begin{array}{c}-0,174 \\
(-0,346)\end{array}$ & $\begin{array}{c}-0,260 \\
(-1,224)\end{array}$ & $\begin{array}{c}-0,165 \\
(-1,568)\end{array}$ & $\begin{array}{c}-0,295 \\
(-1,596)\end{array}$ & $\begin{array}{c}0,628 \\
(0,841)\end{array}$ \\
\cline { 2 - 6 } Prob_Dif & $\begin{array}{c}0,121 \\
(2,219)\end{array}$ & $\begin{array}{c}0,012 \\
(0,538)\end{array}$ & $\begin{array}{c}0,017 \\
(1,539)\end{array}$ & $\begin{array}{c}0,018 \\
(0,926)\end{array}$ & $\begin{array}{c}-0,101 \\
(-1,247)\end{array}$ \\
\cline { 2 - 6 } Inv & $\begin{array}{c}-0,002 \\
(-0,065)\end{array}$ & $\begin{array}{c}-0,009 \\
(-0,600)\end{array}$ & $\begin{array}{c}-0,002 \\
(-0,273)\end{array}$ & $\begin{array}{c}-0,008 \\
(-0,637)\end{array}$ & $\begin{array}{c}0,004 \\
(0,087)\end{array}$ \\
\cline { 2 - 6 } ProbxInv & $\begin{array}{c}0,132 \\
(0,188)\end{array}$ & $\begin{array}{c}0,070 \\
(0,235)\end{array}$ & $\begin{array}{c}0,118 \\
(0,799)\end{array}$ & $\begin{array}{c}0,620^{* *} \\
(2,404)\end{array}$ & $\begin{array}{c}0,120 \\
(0,115)\end{array}$ \\
\cline { 2 - 6 } Prob_Difx Inv & $\begin{array}{c}-0,079 \\
(-1,043)\end{array}$ & $\begin{array}{c}0,009 \\
(-0,288)\end{array}$ & $\begin{array}{c}-0,026 \\
(-1,642)\end{array}$ & $\begin{array}{c}-0,068^{* *} \\
(-2,471)\end{array}$ & $\begin{array}{c}0,029 \\
(0,257)\end{array}$ \\
\hline Pseudo R & 0,0424 & 0,0158 & 0,0064 & 0,0123 & 0,0727 \\
\hline
\end{tabular}

Painel B - Decisão 1

\begin{tabular}{lccccc}
\hline \multirow{2}{*}{ Obs=384 } & \multicolumn{5}{c}{ Coeficientes } \\
\cline { 2 - 6 } & Q05 & Q25 & Q50 & Q75 & Q95 \\
\hline \multirow{2}{*}{ Prob } & $-0,033$ & $-0,050$ & $-0,021$ & 0,292 & $1,394^{* * *}$ \\
\multirow{4}{*}{ Prob_Dif } & $(-0,915)$ & $(-0,516)$ & $(-0,172)$ & $(0,888)$ & $(13,864)$ \\
\cline { 2 - 6 } & 0,003 & 0,021 & 0,002 & $-0,036$ & $-0,258^{* * *}$ \\
Inv & $(0,723)$ & $(1,916)$ & $(0,135)$ & $(0,985)$ & $(-22,993)$ \\
\cline { 2 - 6 } & $-0,009^{* * *}$ & $-0,011$ & 0,009 & 0,007 & 0,007 \\
ProbxInv & $(-3,747)$ & $(-1,566)$ & $(1,109)$ & $(0,304)$ & $(1,015)$ \\
\cline { 2 - 6 } Prob_Difx Inv & $0,176^{* * *}$ & $0,332^{* * *}$ & 0,282 & 0,426 & $-0,327$ \\
\cline { 2 - 6 } & $(3,414)$ & $(2,401)$ & $(1,627)$ & $(0,915)$ & $(-2,299)$ \\
\hline Pseudo R $R^{2}$ & $0,012^{* *}$ & $-0,007$ & $-0,058^{* * *}$ & $-0,009$ & $0,100^{* * *}$ \\
& $(2,140)$ & $(0,456)$ & $(-3,109)$ & $(0,187)$ & $(6,554)$ \\
\hline
\end{tabular}


Painel C - Decisão 2

\begin{tabular}{|c|c|c|c|c|c|}
\hline \multirow{2}{*}{ Obs $=300$} & \multicolumn{5}{|c|}{ Coeficientes } \\
\hline & Q05 & Q25 & Q50 & Q75 & Q95 \\
\hline Prob & $\begin{array}{c}-0,485^{*} \\
(-1,686)\end{array}$ & $\begin{array}{c}0,052 \\
(-0,190)\end{array}$ & $\begin{array}{c}-0,242 \\
(-1,109)\end{array}$ & $\begin{array}{c}0,148 \\
(0,524)\end{array}$ & $\begin{array}{c}0,589 \\
(1,423)\end{array}$ \\
\hline Prob_Dif & $\begin{array}{l}0,069^{* *} \\
(2,415)\end{array}$ & $\begin{array}{c}-0,009 \\
(-0,345)\end{array}$ & $\begin{array}{c}0,005 \\
(0,235)\end{array}$ & $\begin{array}{c}0,038 \\
(1,335)\end{array}$ & $\begin{array}{l}-0,113^{* *} \\
(-2,733)\end{array}$ \\
\hline $\operatorname{Inv}$ & $\begin{array}{c}0,198^{* * * *} \\
(9,074)\end{array}$ & $\begin{array}{c}0,007 \\
(0,352)\end{array}$ & $\begin{array}{c}-0,011 \\
(-0,674)\end{array}$ & $\begin{array}{c}-0,013 \\
(-0,600)\end{array}$ & $\begin{array}{l}-0,073^{* *} \\
(-2,328)\end{array}$ \\
\hline Prob $x$ Inv & $\begin{array}{l}-6,155^{* * * *} \\
(-13,456)\end{array}$ & $\begin{array}{c}-0,471 \\
(-1,083)\end{array}$ & $\begin{array}{c}-0,009 \\
(-0,026)\end{array}$ & $\begin{array}{c}-0,081 \\
(-0,181)\end{array}$ & $\begin{array}{c}0,729 \\
(1,107)\end{array}$ \\
\hline Prob_Dif $x$ Inv & $\begin{array}{c}-0,183^{* * *} \\
(-3,633) \\
\end{array}$ & $\begin{array}{c}0,001 \\
(0,015) \\
\end{array}$ & $\begin{array}{c}0,003 \\
(0,080)\end{array}$ & $\begin{array}{c}0,017 \\
(0,345)\end{array}$ & $\begin{array}{l}0,168^{* *} \\
(2,318)\end{array}$ \\
\hline Pseudo $R^{2}$ & 0,1572 & 0,0577 & 0,0290 & 0,0383 & 0,0696 \\
\hline
\end{tabular}

Painel D - Decisão 3

\begin{tabular}{lccccc}
\hline \multirow{2}{*}{ Obs=270 } & \multicolumn{5}{c}{ Coeficientes } \\
\cline { 2 - 6 } & Q05 & Q25 & Q50 & Q75 & Q95 \\
\hline \multirow{2}{*}{ Prob } & $-0,149$ & 0,024 & $-0,104$ & $-0,113^{*}$ & $-0,082^{*}$ \\
& $(-0,340)$ & $(0,112)$ & $(-0,655)$ & $(-1,746)$ & $(-1,736)$ \\
\cline { 2 - 6 } Prob_Dif & $0,200^{* * *}$ & $0,055^{* *}$ & $0,043^{* * *}$ & $0,017^{* * *}$ & $0,022^{* * *}$ \\
& $(4,235)$ & $(2,325)$ & $(2,531)$ & $(2,507)$ & $(4,291)$ \\
\cline { 2 - 6 } Inv & 0,038 & $-0,006$ & $-0,003$ & 0,004 & 0,002 \\
& $(1,327)$ & $(-0,425)$ & $(-0,292)$ & $(1,069)$ & $(0,838)$ \\
ProbxInv & $-0,189$ & 0,062 & 0,034 & $-0,121$ & 0,047 \\
Prob_Dif $x$ Inv & $(-0,325)$ & $(0,215)$ & $(0,160)$ & $(-1,410)$ & $(0,743)$ \\
\hline \multirow{2}{*}{ Pseudo R $R^{2}$} & $-0,103$ & $-0,001$ & $-0,016$ & $-0,001$ & $-0,018^{* * *}$ \\
& $(-1,649)$ & $(-0,023)$ & $(-0,704)$ & $(-0,084)$ & $(-2,748)$ \\
\hline
\end{tabular}

Painel E - Decisão 4

\begin{tabular}{lccccc}
\hline \multirow{2}{*}{ Obs=114 } & \multicolumn{5}{c}{ Coeficientes } \\
\cline { 2 - 6 } & Q05 & Q25 & Q50 & Q75 & Q95 \\
\hline \multirow{2}{*}{ Prob } & $0,072^{* * *}$ & 0,129 & 0,355 & $0,814^{* * *}$ & $1,222^{* *}$ \\
& $(66,230)$ & $(1,003)$ & $(1,614)$ & $(3,287)$ & $(2,497)$ \\
\cline { 2 - 6 } Prob_Dif & $0,011^{* * *}$ & $0,038^{* * *}$ & 0,034 & 0,025 & 0,063 \\
& $(101,920)$ & $(2,922)$ & $(1,558)$ & $(1,005)$ & $(1,278)$ \\
\cline { 2 - 6 } Inv & $0,006^{* * *}$ & 0,005 & $-0,002$ & $-0,014$ & $-0,067$ \\
ProbxInv & $(52,483)$ & $(0,340)$ & $(-0,097)$ & $(-0,506)$ & $(-1,210)$ \\
\cline { 2 - 6 } & $0,051^{* * *}$ & $-0,054$ & $-0,090$ & 0,786 & 1,229 \\
Prob_Difx Inv & $(22,872)$ & $(-0,205)$ & $(-0,201)$ & $(1,556)$ & $(1,229)$ \\
\hline \multirow{2}{*}{ Pseudo R $R^{2}$} & $-0,035^{* * *}$ & $-0,028$ & 0,001 & $-0,016$ & 0,086 \\
& $(-129,352)$ & $(-0,892)$ & $(0,022)$ & $(-0,272)$ & $(0,711)$ \\
\hline
\end{tabular}

Fonte: dados da pesquisa 
Tabela 38 - Adesão aos Segmentos de Governança Corporativa da BM\&FBovespa (GOVERN) - Equação (35)

Painel A - Amostra Total

\begin{tabular}{lccccc}
\hline \multirow{2}{*}{ Obs=846 } & \multicolumn{5}{c}{ Coeficientes } \\
\cline { 2 - 6 } & Q05 & Q25 & Q50 & Q75 & Q95 \\
\hline \multirow{2}{*}{ Prob } & $\begin{array}{c}-0,600^{* *} \\
(-2,094)\end{array}$ & $\begin{array}{c}-0,337^{*} \\
(-1,817)\end{array}$ & $\begin{array}{c}-0,266^{*} \\
(-1,929)\end{array}$ & $\begin{array}{c}-0,329^{*} \\
(-1,913)\end{array}$ & $\begin{array}{c}-0,687 \\
(-1,493)\end{array}$ \\
\cline { 2 - 6 } Prob_Dif & $\begin{array}{c}0,141^{* * *} \\
(4,664)\end{array}$ & $\begin{array}{c}0,009 \\
(0,462)\end{array}$ & $\begin{array}{c}0,015 \\
(1,072)\end{array}$ & $\begin{array}{c}0,025 \\
(1,375)\end{array}$ & $\begin{array}{c}-0,055 \\
(-1,146)\end{array}$ \\
\cline { 2 - 6 } Gov & $\begin{array}{c}-0,007 \\
(-0,365)\end{array}$ & $\begin{array}{c}-0,030^{* *} \\
(-2,239)\end{array}$ & $\begin{array}{c}-0,014 \\
(-1,416)\end{array}$ & $\begin{array}{c}0,016 \\
(1,311)\end{array}$ & $\begin{array}{c}-0,056 \\
(-1,643)\end{array}$ \\
\cline { 2 - 6 } ProbxGov & $\begin{array}{c}0,392 \\
(0,938)\end{array}$ & $\begin{array}{c}0,430 \\
(1,594)\end{array}$ & $\begin{array}{c}0,454^{* *} \\
(2,257)\end{array}$ & $\begin{array}{c}0,717^{* * *} \\
(2,862)\end{array}$ & $\begin{array}{c}1,851^{* * *} \\
(2,759)\end{array}$ \\
\cline { 2 - 6 } Prob_DifxGov & $\begin{array}{c}-0,073 \\
(-1,446)\end{array}$ & $\begin{array}{c}0,032 \\
(0,963)\end{array}$ & $\begin{array}{c}-0,006 \\
(-0,262)\end{array}$ & $\begin{array}{c}-0,146^{* * *} \\
(-4,778)\end{array}$ & $\begin{array}{c}-0,032 \\
(-0,391)\end{array}$ \\
\hline Pseudo R & 0,0398 & 0,0158 & 0,0061 & 0,0220 & 0,1074 \\
\hline
\end{tabular}

Painel B - Decisão 1

\begin{tabular}{lccccc}
\hline \multirow{2}{*}{ Obs=384 } & \multicolumn{5}{c}{ Coeficientes } \\
\cline { 2 - 6 } & $\mathrm{Q} 05$ & $\mathrm{Q} 25$ & $\mathrm{Q} 50$ & $\mathrm{Q} 75$ & $\mathrm{Q} 95$ \\
\hline \multirow{2}{*}{ Prob } & $-0,033^{* * *}$ & 0,049 & $-0,096$ & 0,159 & 0,145 \\
& $\left(-2,60 \times 10^{6}\right)$ & $(0,694)$ & $(-0,643)$ & $(0,977)$ & $(0,317)$ \\
\cline { 2 - 6 } Prob_Dif & $0,005^{* * *}$ & $0,023^{* * *}$ & 0,02 & $-0,028$ & $-0,202^{* * *}$ \\
& $\left(3,53 \times 10^{6}\right)$ & $(3,140)$ & $(1,498)$ & $(-1,657)$ & $(-4,173)$ \\
\cline { 2 - 6 } Gov & $-0,008^{* * *}$ & $0,011^{* *}$ & $0,029^{* * *}$ & 0,006 & $-0,052$ \\
ProbxGov & $\left(-8,80 \times 10^{6}\right)$ & $(2,099)$ & $(2,729)$ & $(0,540)$ & $(-1,552)$ \\
\cline { 2 - 6 } & $0,182^{* * *}$ & $0,193^{*}$ & $0,484^{* *}$ & $0,961^{* * *}$ & $1,393^{* *}$ \\
Prob_DifxGov & $\left(1,005 \times 10^{7}\right)$ & $(1,936)$ & $(2,305)$ & $(4,188)$ & $(2,154)$ \\
\hline \multirow{2}{*}{ Pseudo R $R^{2}$} & $0,009^{* * * *}$ & $-0,054^{* * *}$ & $-0,150^{* * *}$ & $-0,089^{* * *}$ & 0,025 \\
$\left(3,950 \times 10^{6}\right)$ & $(-4,421)$ & $(-5,789)$ & $(-3,142)$ & $(0,309)$ \\
\hline
\end{tabular}

Painel C - Decisão 2

\begin{tabular}{|c|c|c|c|c|c|}
\hline \multirow{2}{*}{ Obs $=300$} & \multicolumn{5}{|c|}{ Coeficientes } \\
\hline & Q05 & Q25 & Q50 & Q75 & Q95 \\
\hline Prob & $\begin{array}{l}-0,623^{*} \\
(-1,956)\end{array}$ & $\begin{array}{c}-0,190 \\
(-0,876)\end{array}$ & $\begin{array}{c}-0,120 \\
(-0,810)\end{array}$ & $\begin{array}{c}-0,253 \\
(-1,576)\end{array}$ & $\begin{array}{c}-0,353 \\
(-1,093)\end{array}$ \\
\hline Prob_Dif & $\begin{array}{c}-0,002 \\
(-0,075)\end{array}$ & $\begin{array}{c}-0,036 \\
(-1,695)\end{array}$ & $\begin{array}{c}-0,019 \\
(-1,323)\end{array}$ & $\begin{array}{l}0,035^{\text {** }} \\
(2,273)\end{array}$ & $\begin{array}{c}-0,051 \\
(-1,617)\end{array}$ \\
\hline Gov & $\begin{array}{c}0,021 \\
(0,734)\end{array}$ & $\begin{array}{c}-0,029 \\
(-1,516)\end{array}$ & $\begin{array}{c}-0,047 \\
(-3,597)\end{array}$ & $\begin{array}{c}-0,023 \\
(-1,640)\end{array}$ & $\begin{array}{c}-0,079^{* *} \\
(-2,769)\end{array}$ \\
\hline Prob $x$ Gov & $\begin{array}{l}-0,842^{*} \\
(-1,717)\end{array}$ & $\begin{array}{c}-0,384 \\
(-1,152)\end{array}$ & $\begin{array}{c}-0,068 \\
(-0,297)\end{array}$ & $\begin{array}{c}0,045 \\
(0,184)\end{array}$ & $\begin{array}{l}1,932^{* * *} \\
(3,895)\end{array}$ \\
\hline Prob_Dif $x$ Gov & $\begin{array}{c}0,010 \\
(0,139)\end{array}$ & $\begin{array}{c}0,163^{\text {*** }} \\
(3,214)\end{array}$ & $\begin{array}{c}0,164^{\text {*** }} \\
(4,703)\end{array}$ & $\begin{array}{c}0,052 \\
(1,373)\end{array}$ & $\begin{array}{c}0,093 \\
(1,224)\end{array}$ \\
\hline Pseudo $R^{2}$ & 0,0388 & 0,0680 & 0,0438 & 0,0356 & 0,1090 \\
\hline
\end{tabular}


Painel D - Decisão 3

\begin{tabular}{lccccc}
\hline \multirow{2}{*}{ Obs=270 } & \multicolumn{5}{c}{ Coeficientes } \\
\cline { 2 - 6 } & Q05 & Q25 & Q50 & Q75 & Q95 \\
\hline \multirow{2}{*}{ Prob } & $\begin{array}{c}-0,035 \\
(-0,479)\end{array}$ & 0,046 & $-0,051$ & 0,138 & $-0,074$ \\
& 0,002 & $-0,005$ & $-0,001$ & $-0,028$ & $-0,180^{*}$ \\
Prob_Dif & $(0,266)$ & $(-0,275)$ & $(-0,060)$ & $(-0,706)$ & $(-1,718)$ \\
\cline { 2 - 6 } Gov & $-0,009^{*}$ & 0,012 & $0,042^{* * *}$ & 0,006 & $-0,043$ \\
& $(-1,795)$ & $(1,000)$ & $(2,895)$ & $(0,255)$ & $(-0,685)$ \\
\cline { 2 - 6 } ProbxGov & 0,162 & 0,095 & $-0,070$ & $0,822^{*}$ & 1,143 \\
Prob_DifxGov & $(1,629)$ & $(0,389)$ & $(-0,237)$ & $(1,718)$ & $(0,891)$ \\
\cline { 2 - 6 } & 0,014 & $-0,034$ & $-0,114$ & $-0,066$ & 0,013 \\
Pseudo R & $(1,164)$ & $(-1,152)$ & $(-3,230)$ & $(-1,150)$ & $(0,082)$ \\
\hline
\end{tabular}

Painel E - Decisão 4

\begin{tabular}{|c|c|c|c|c|c|}
\hline \multirow[t]{2}{*}{ Obs $=114$} & \multicolumn{5}{|c|}{ Coeficientes } \\
\hline & Q05 & Q25 & Q50 & Q75 & Q95 \\
\hline Prob & $\begin{array}{c}0,084 \\
(1,440)\end{array}$ & $\begin{array}{c}0,110^{* * *} \\
(7,347)\end{array}$ & $\begin{array}{c}0,283 \\
(4,585)\end{array}$ & $\begin{array}{c}0,119 \\
(0,600)\end{array}$ & $\begin{array}{l}0,605^{* *} \\
(2,577)\end{array}$ \\
\hline Prob_Dif & $\begin{array}{c}0,015^{* * *} \\
(2,721)\end{array}$ & $\begin{array}{l}0,033^{* * *} \\
(23,218)\end{array}$ & $\begin{array}{c}0,040 \\
(6,927)\end{array}$ & $\begin{array}{c}0,021 \\
(1,125)\end{array}$ & $\begin{array}{c}0,019 \\
(-0,888)\end{array}$ \\
\hline Gov & $\begin{array}{c}0,030^{* * *} \\
(4,077)\end{array}$ & $\begin{array}{l}0,041^{* * *} \\
(22,042)\end{array}$ & $\begin{array}{c}-0,030^{* * *} \\
(-3,935)\end{array}$ & $\begin{array}{l}-0,054^{* *} \\
(-2,194)\end{array}$ & $\begin{array}{l}{ }_{-0,141^{* * *}} \\
(-4,819)\end{array}$ \\
\hline Prob $x$ Gov & $\begin{array}{c}0,343^{* * *} \\
(3,374)\end{array}$ & $\begin{array}{c}0,151^{\text {*** }} \\
(5,809)\end{array}$ & $\begin{array}{c}1,498^{* * *} \\
(14,038)\end{array}$ & $\begin{array}{l}1,832^{\text {*** }} \\
(5,315)\end{array}$ & $\begin{array}{l}1,492^{* * *} \\
(3,672)\end{array}$ \\
\hline Prob_Difx Gov & $\begin{array}{c}-0,160^{* * * *} \\
(-7,569)\end{array}$ & $\begin{array}{c}-0,159 \\
(-29,478) \\
\end{array}$ & $\begin{array}{c}-0,031 \\
(-1,420)\end{array}$ & $\begin{array}{c}0,025 \\
(0,352)\end{array}$ & $\begin{array}{c}0,362 \\
(4,275)\end{array}$ \\
\hline Pseudo $R^{2}$ & 0,0457 & 0,0972 & 0,1340 & 0,1856 & 0,2830 \\
\hline
\end{tabular}

Fonte: dados da pesquisa 